\author{
ZENTRUM \\ FÜR BIODIVERSITÄT UND NACHHALTIGE LANDNUTZUNG \\ SEKTION \\ BIOdIVERSITÄT, ÖKOLOGIE UND NATURSCHUTZ \\ - Centre of Biodiversity and Sustainable Land Use - \\ SECTION: BIOdIVERsity, Ecology and Nature Conservation
}

\title{
Functional diversity of mycorrhizal fungi \\ with regard to nutrient transfer
}

\author{
Dissertation zur Erlangung des Doktorgrades der \\ Mathematisch-Naturwissenschaftlichen Fakultäten der \\ Georg-August-Universität Göttingen
}

vorgelegt von

Dipl. Biol.

Kerttu Valtanen

aus

Kajaani

Göttingen, Dezember, 2012 
Referentin/Referent:

Korreferentin/Korreferent:

Tag der mündlichen Prüfung:
Prof. Dr. Andrea Polle

Prof. Dr. Christoph Leuschner

18.12.2012 


\section{List of Contents}

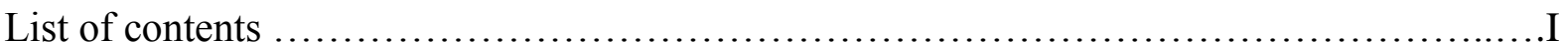

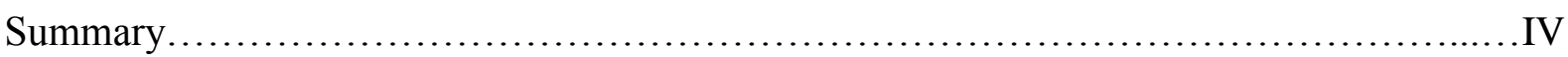

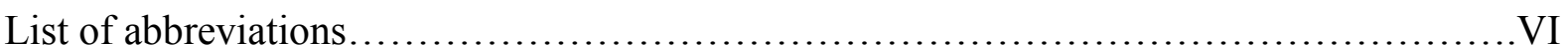

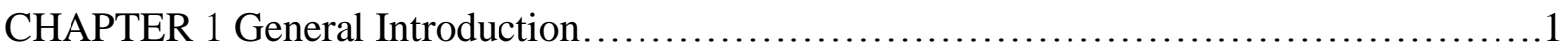

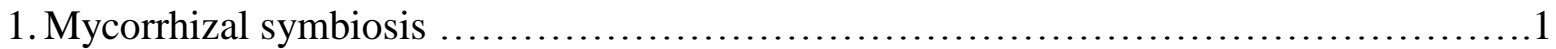

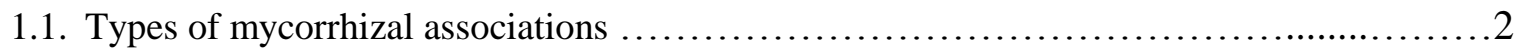

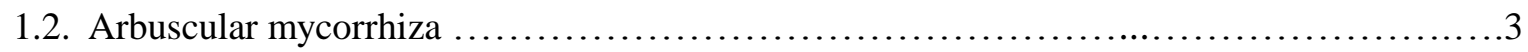

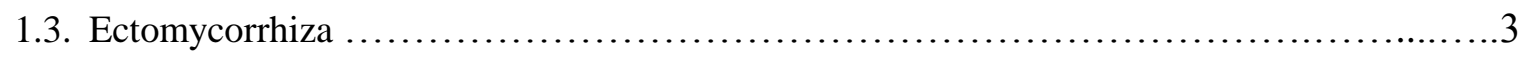

1.4. Functions of mycorrhizal association .....................................................

2. Nitrogen and phosphorus in plant nutrition .......................................

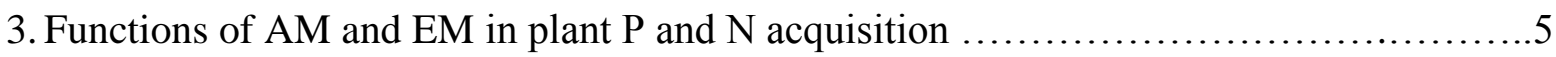

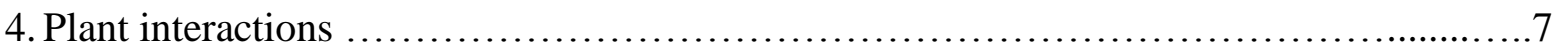

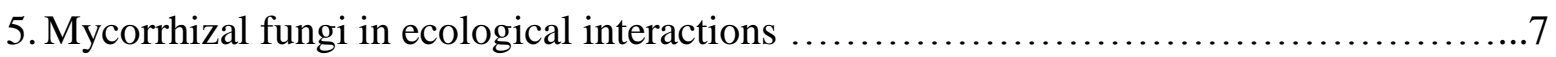

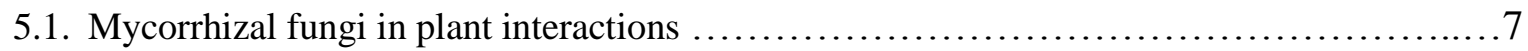

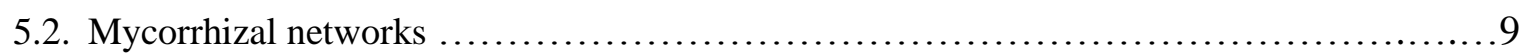

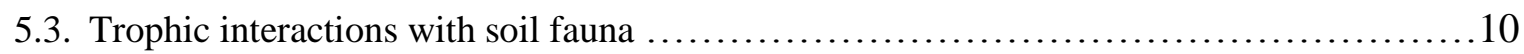

6. Ecological characteristics of beech (Fagus sylvatica) and ash (Fraxinus excelsior) .......11

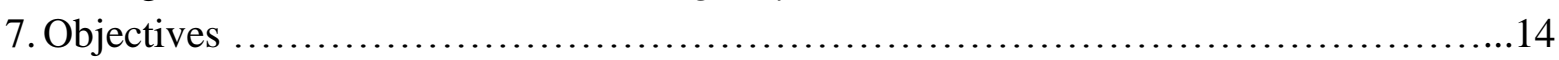

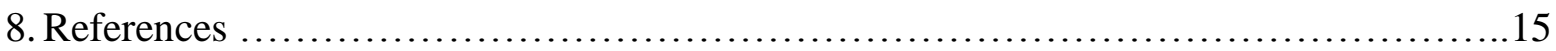

CHAPTER 2 The competition for phosphorus between beech (Fagus sylvatica) and ash (Fraxinus excelsior) .......................25

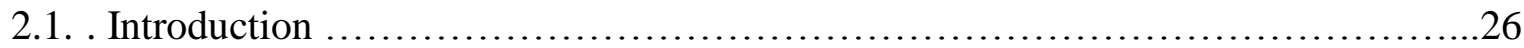

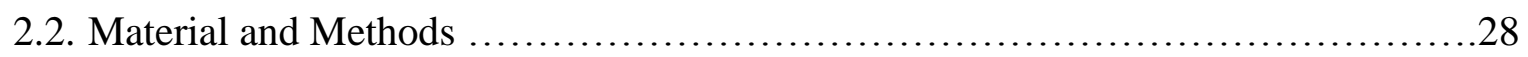

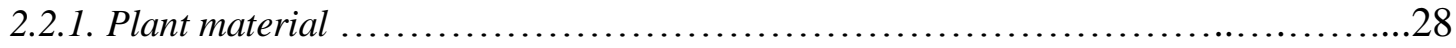

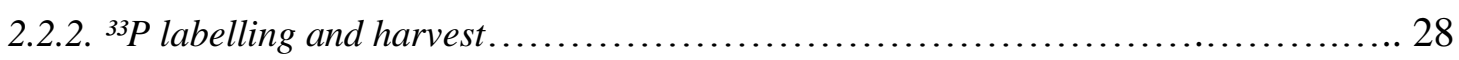

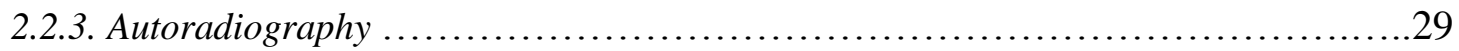

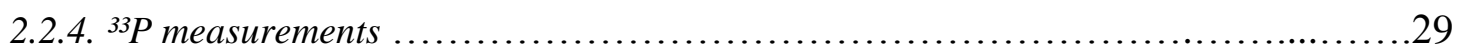

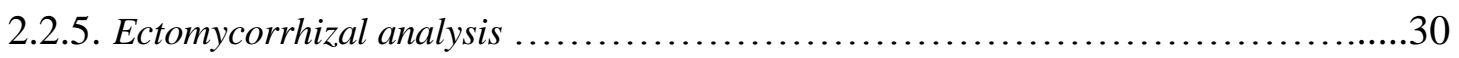

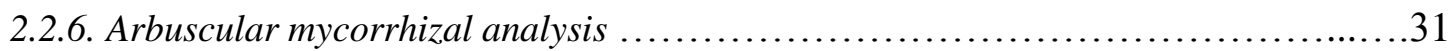

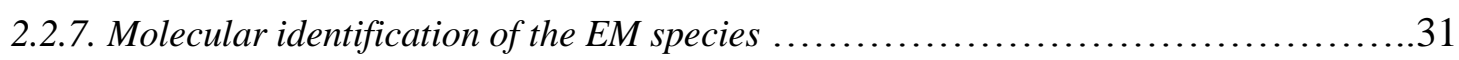

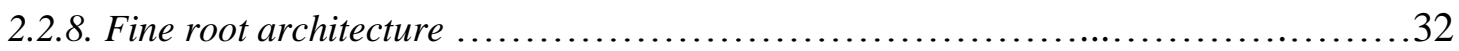

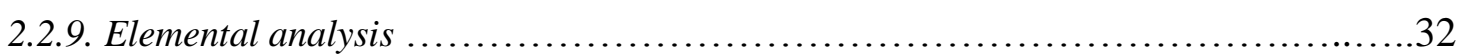

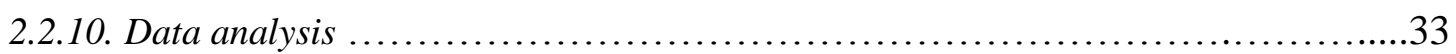

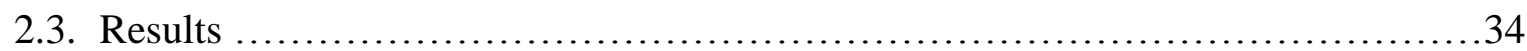

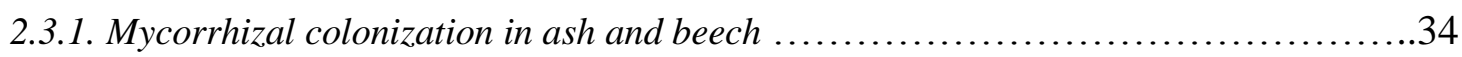

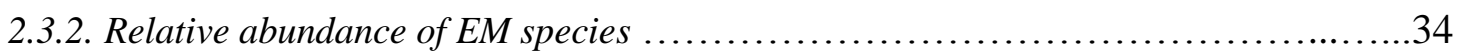

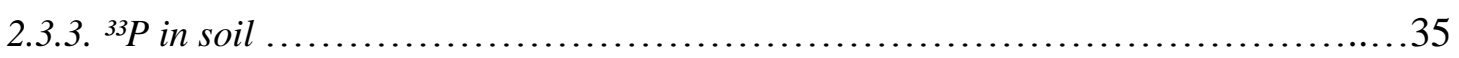

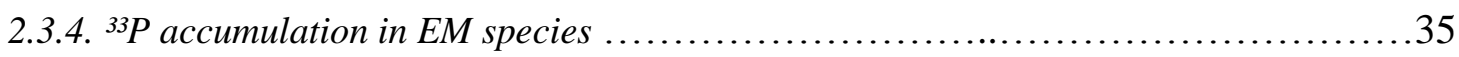




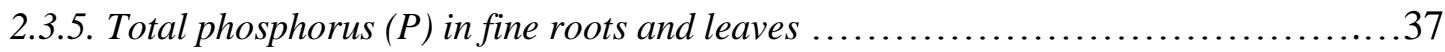

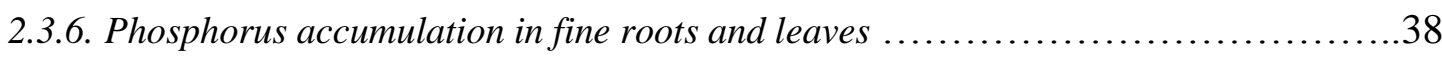

2.3.7. ${ }^{33} \mathrm{P}$ uptake rate .......................................................45

2.3.8. Root morphology ......................................................... 45

2.3.9. Competition intensity ..................................................46

2.3.10. The effect of interspecific and intraspecific competition on plant growth ............46

2.3.11. The effect of competition for phosphorus on plant growth .........................47

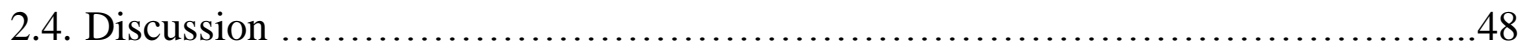

2.4.1. Plant phosphorus uptake in nutrient limited conditions ..........................48

2.4.2. Species specific differences in phosphorus uptake of $E M$......................... 48

2.4.3. Phosphorus accumulation via mycorrhiza ..................................49

2.4.4. Total phosphorus in leaves indicates $P$ deficiency .............................50

2.4.5. ${ }^{33} \mathrm{P}$ accumulation in leaves and fine roots ...................................51

2.4.6. Interspecific competition for phosphorus ...................................52

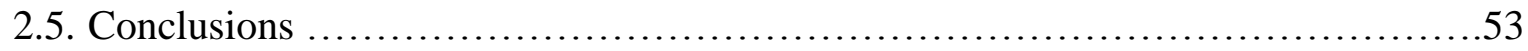

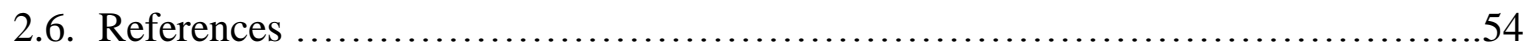

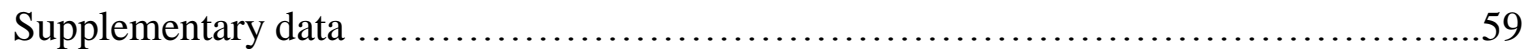

3. CHAPTER 3 Plant nitrogen accumulation under intra- and interspecific competition in relation to phosphorus accumulation .............66

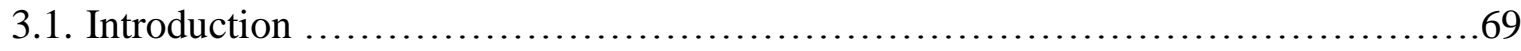

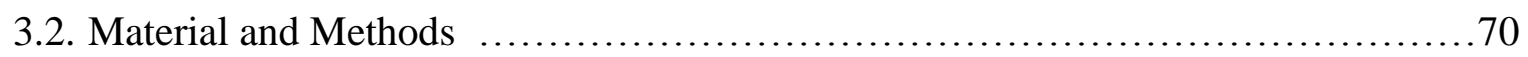

3.2.1. Plant material ......................................................... 70

3.2.2. Labelling and harvest ................................................... 70

3.2.3. ${ }^{15} \mathrm{~N}$ isotope analysis and $\mathrm{N}$ uptake rate ...................................... 71

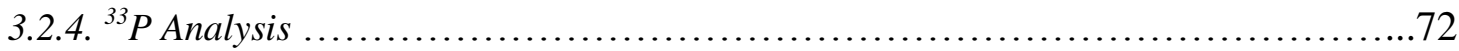

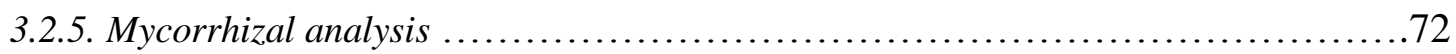

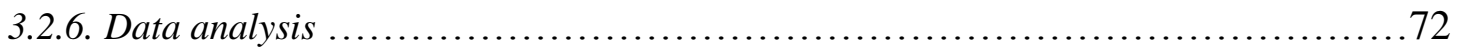

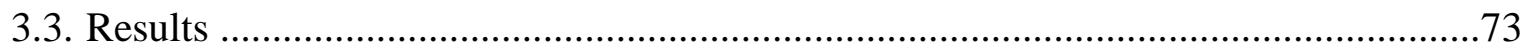

3.3.1. Total carbon and nitrogen in leaves and fine roots ...........................73

3.3.2. ${ }^{15} \mathrm{~N}$ accumulation in leaves and fine roots .....................................74

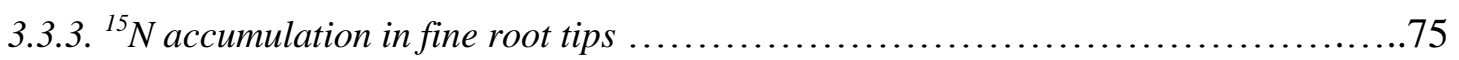

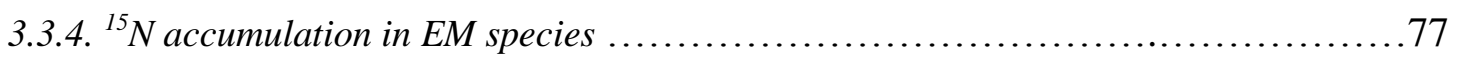

3.3.5. Relationship of ${ }^{15} \mathrm{~N}$ in mycorrhizal root tips and total fine root ${ }^{15} \mathrm{~N} \ldots \ldots \ldots \ldots \ldots \ldots . . . . .78$

3.3.6. Relationship of ${ }^{15} \mathrm{~N}$ signatures in fine roots and leaves ...........................79

3.3.7. Short-term ${ }^{15} N$ and ${ }^{33} P$ supply in mycorrhizal and $N M$ root tips ...................80

3.3.8. Comparison of long-term and short-term

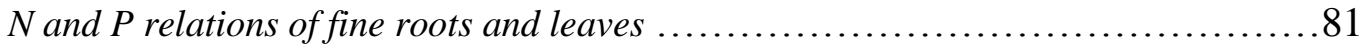

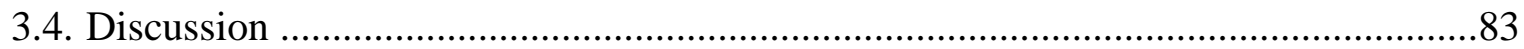

3.4.1. Nitrogen uptake of beech and ash in heterospecific and conspecific pairs .............83

3.4.2. The role of EM species in plant $N$ and $P$ uptake ...............................84

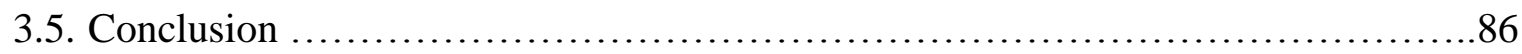

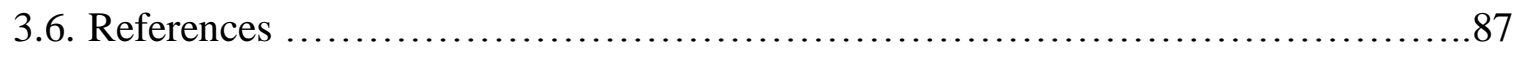


CHAPTER 4 Ectomycorrhiza as a link between trees

(Fagus sylvatica) and the belowground food web

4.1. Introduction ............................................................... 92

4.2. Material and methods ..................................................... 94

4.2.1.Plant material and experimental setup ..................................... 94

4.2.2. Plant harvest and soil collection ...........................................95

4.2.3. Soil animal harvest and identification ..................................... 95

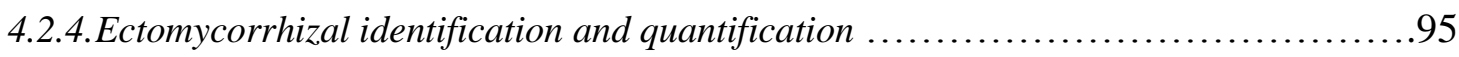

4.2.5.Molecular identification of the EM species .....................................96

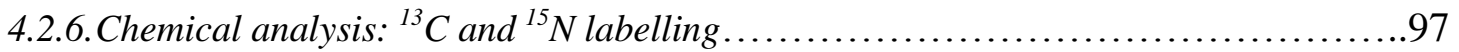

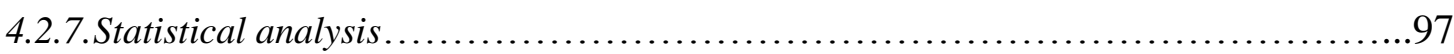

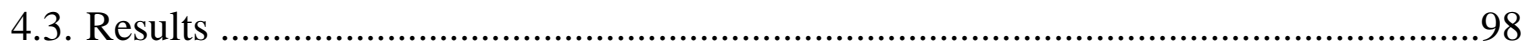

4.3.1. Carbon and nitrogen allocation between plant tissues and soil organisms ...........98

4.3.2.EM mediated $N$ uptake and transfer in relation to carbon incorporation ................99

4.3.3.Trophic relations of soil fauna, beech and ectomycorrhizal fungi ...................102

4.4. Discussion ......................................................... 104

4.4.1.The experimental setup maintain a fungal beech EM community....................104

4.4.2. Nitrogen accumulation in ectomycorrhizal fungi ................................104

4.4.3.EM have a high nutritional value .............................................106

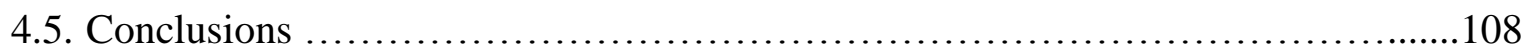

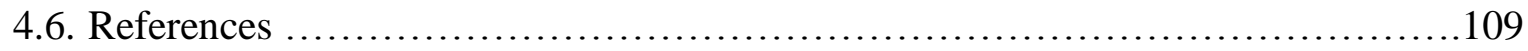

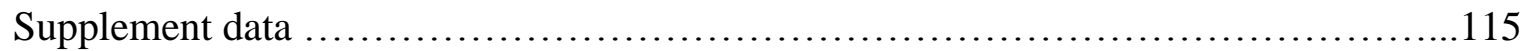

GENERAL DISCUSSION ......................................................119

5.1 Differential interactions between mycorrhizal fungi and tree species

impact the structure and dynamics of plant communities.........................................120

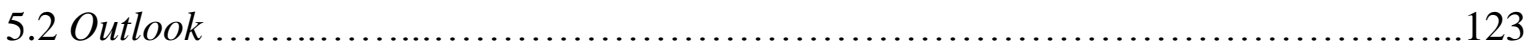

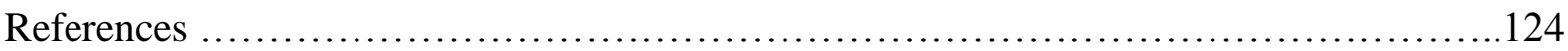

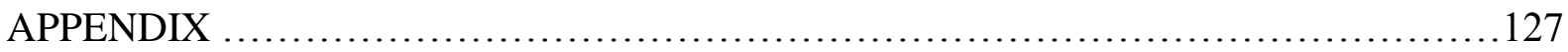

Appendix 1 Roots from beech (Fagus sylvatica L.) and ash

(Fraxinus excelsior L.) differentially affect soil microorganisms and carbon dynamics ........................................127

Appendix 2 Beech carbon productivity as driver of ectomycorrhizal

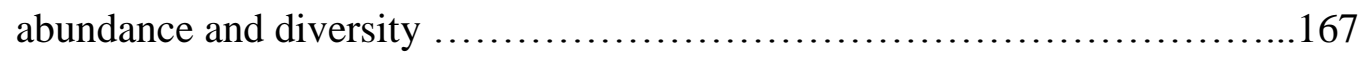

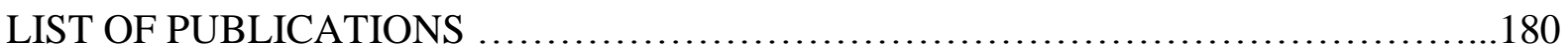

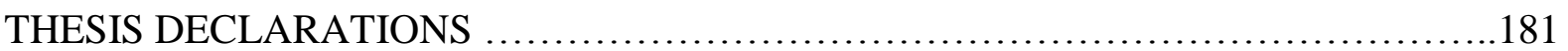

Declarations of the authors own contributions to

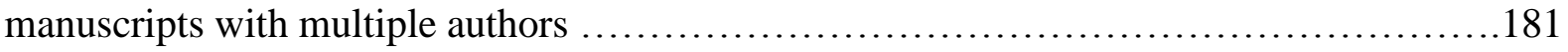

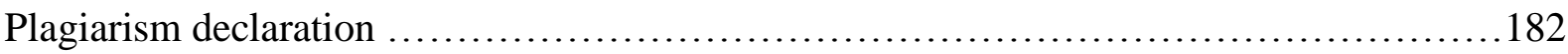




\section{Summary}

Mycorrhizal associations of tree species are important drivers of plant belowground interactions. The main objective of this study was to investigate the contribution of mycorrhizal fungi on plant competition for nutrients. Another goal of the present study was to determine nutrient and carbon fluxes between trees, and soil food web via mycorrhizal fungi.

The influence of interspecific interactions on $\mathrm{N}$ and $\mathrm{P}$ acquisition of ash (Fraxinus excelsior) and beech was analysed in nutrient limited conditions. Beech and ash saplings were grown in conspecific and heterospecific pairs and labelled with nutrient solution containing $6.27 \mathrm{ng}$ ${ }^{33} \mathrm{PH}_{3}{ }^{33} \mathrm{PO}_{4}(3.7 \mathrm{MBq})$ and $4 \mathrm{mM}{ }^{15} \mathrm{NH}_{4}{ }^{15} \mathrm{NO}_{3}$. The growth of beech was not influenced by the species identity of the neighbouring tree, whereas the height growth of ash decreased in the presence of beech. Beech was also neutral to interspecific competition for nutrients, whereas ash shifted to increased deprivation of $\mathrm{N}$ and $\mathrm{P}$ in the presence of beech.

The $\mathrm{N}$ and $\mathrm{P}$ accumulation was higher in EM root tips than in vital ash roots and nonmycorrhizal beech roots. Non-mycorrhizal beech root tips accumulated 1.2 times less $\mathrm{N}$ and 4.2 times less $\mathrm{P}$ than mycorrhizal root tips. Vital ash fine root tips accumulated 2.3 times less $\mathrm{N}$ and 6.7 times less $\mathrm{P}$ than mycorrhizal beech root tips. The $\mathrm{N}$ and $\mathrm{P}$ concentrations of beech fine roots and mycorrhizal root tips were positively correlated.

Differences in $\mathrm{N}$ and $\mathrm{P}$ accumulation of EM species demonstrated the functional diversity within beech roots colonizing EM community. The most abundant EM species Tomentella castanea and Sebacina sp. (81.7 \% mono; 89.2\% mix) had high $\mathrm{P}$ and $\mathrm{N}$ accumulation.

The ability of tree species to use organic $\mathrm{N}$ and carbon (C) was examined using ${ }^{15} \mathrm{~N}$ and ${ }^{13} \mathrm{C}$ enriched litter in double-split-root rhizotrons planted with ash and beech saplings (Chapter 4). Nitrogen uptake from litter was documented in both ash and beech. No C from organic origin was detected in fine roots or other plant tissues after 475 days of incubation. Although beech root biomass was significantly lower than that of ash only beech decreased soil carbon and nitrogen concentrations significantly. These results suggest that trees, which are colonized by mycorrhizal fungi, use organic nutrient sources. However, the allocation of $\mathrm{C}$ is presumably unidirectional, namely from plant to fungus. 
In another experiment we demonstrated that when the allocation carbon from photoassimilates was inhibited through girdling, EM was supplied from root carbon storages (Appendix, Chapter 6).

The path of plant derived $\mathrm{C}$ via EM fungi to soil food web was analyzed using ${ }^{15} \mathrm{NO}_{3}{ }^{15} \mathrm{NH}_{4}$ and ${ }^{13} \mathrm{CO}_{2}$ labelling. Beech saplings from Hainich national park were removed with intact soil cores in order to maintain intact soil community and labelled for five months in a green house. The highest concentrations of ${ }^{13} \mathrm{C}$ and ${ }^{15} \mathrm{~N}$ were found in mycorrhizal root tips. The strong relation of ${ }^{15} \mathrm{~N}$ in EM root tips and adjacent fine root demonstrated that ${ }^{15} \mathrm{~N}$ taken up by the EM fungus was mainly transported to host plant. The results demonstrated that mycorrhizal structures are an important nutrient source for soil animals and a considerable channel of plant C into soil food web.

Based on the present results, the interactions between beech and ash are suggested to be driven mainly by effects of beech and associated EM fungi. It can be concluded that abundant root colonizing EM fungi significantly contribute to $\mathrm{N}$ and $\mathrm{P}$ nutrition of beech. 
II List of abbreviations

$\mu$

${ }^{\circ} \mathrm{C}$

A

$\mathrm{AD}$

AM

ANOVA

As

Be

$\mathrm{Bq}$

c

d

df

$\mathrm{dw}$

E. coli

EM

et al.

FoA

FR

$\mathrm{g}$

$\mathrm{h}$

ha

ITS

$\mathrm{k}$

1

$\mathrm{m}$

m (prefix)

$\mathrm{M}$

$\mathrm{M}$

$\min$

mix

MN

mono

$n$

$\mathrm{n}$

NCBI

Nds.

NM

PAR
Micro $\left(10^{-6}\right)$

Degree Celsius

Activity

Average diameter

Arbuscular mycorrhiza

Analysis of variance

Ash (Fraxinus excelsior L.)

Beech (Fagus sylvatica L.)

Bequerel

Centi $\left(10^{-2}\right)$

Day

Degrees of freedom

Dry weight

Escherichia coli

Ectomycorrhiza

et alii

Forestry office

Fine root

Gramm

Hour

Hectar

Internal transcribed spacer

Kilo $\left(10^{-3}\right)$

Litre

Meter

Milli $\left(10^{-3}\right)$

Molar

Mega $\left(10^{6}\right)$

Minute

Mixture

Mycorrhizal network

Monoculture

Amount of substances

Nano $\left(10^{-9}\right)$

National Center of Biotechnology

Information

Niedersachsen

Non-mycorrhizal

Photosynthetically active radiation 
PCR

ppm

RAG

RCI

$S$

SA

SE

SLA

SRL

SSA

$t$

$v$

$v S$
Polymerase chain reaction

Parts per million $\left(10^{-6}\right)$

Relative annual height growth

Relative competition intensity

Second

Surface area

Standard error

Specific leaf area

Specific root length

Specific surface area

Time

Uptake rate

versus 
Chapter 1

\section{GENERAL INTRODUCTION}




\section{Mycorrhizal symbiosis}

\subsection{Types of mycorrhizal associations}

Mycorrhiza (mýkēs ,fungus, $\mathfrak{\rho} i \zeta \alpha$ rhiza, root) is a symbiosis between specialised soil fungi and higher plants. Approximately $90 \%$ of terrestrial plants form mycorrhizal associations (Trappe 1987).

On the basis of morphological characteristics, mycorrhizal types can be divided into seven main groups: arbuscular mycorrhiza, arbutoid mycorrhiza, ectendomycorrhiza, ectomycorrhiza, ericoid mycorrhiza, monotropoid mycorrhiza and orchid mycorrhiza (Harley \& Smith 1983). Tree species in European temperate forests form different types of mycorrhizal associations, whereof EM is the most prevalent (Tab.1).

Table 1: Examples of mycorrhizal types of common tree species in temperate forest. EM ectomycorrhizal, AM arbuscular mycorrhizal (Cornelissen et al. 2001, Dučić et al. 2009, Lang et al. 2011, Schüßler 2009).

\begin{tabular}{|c|c|c|c|c|c|}
\hline \multicolumn{2}{|c|}{ Deciduous tree species } & \multicolumn{4}{|c|}{ Coniferous tree species } \\
\hline Species & Family & $\begin{array}{c}\text { Mycorrhizal } \\
\text { type }\end{array}$ & Species & Family & $\begin{array}{c}\text { Mycorrhizal } \\
\text { type }\end{array}$ \\
\hline $\begin{array}{l}\text { Fraxinus } \\
\text { excelsior }\end{array}$ & Oleaceae & $\mathrm{AM}$ & Pseudotsuga spp. & Pinaceae & EM/Ectendo \\
\hline Acer spp. & Aceraceae & $\mathrm{AM}$ & Picea abies & Pinaceae & EM \\
\hline Fagus sylvatica & Fagaceae & EM & Abies alba & Pinaceae & EM \\
\hline Quercus spp. & Fagaceae & EM & Larix decidua & Pinaceae & EM \\
\hline Salix spp. & Salicaceae & $\mathrm{AM} / \mathrm{EM}$ & Pinus sylvestris & Pinaceae & EM \\
\hline Populus spp. & Salicaceae & $\mathrm{AM} / \mathrm{EM}$ & Taxus baccata & Taxaceae & $\mathrm{AM}$ \\
\hline
\end{tabular}

The mycorrhizal types contribute differentially to functional traits of plant carbon $(\mathrm{C})$ cycling (Cornelissen et al. 2001). In temperate forests, plants associated with AM display comparatively high growth rates, high foliar nutrient content and fast litter decomposition, whereas trees with EM have intermediate growth ratio, lower foliar nutrient contents and intermediate to slow litter decomposability (Cornelissen et al. 2001). 


\subsection{Arbuscular mycorrhiza}

On basis of 400 million years old fossil funds arbuscular symbiosis (AM) is the oldest type of mycorrhiza. AM are formed by ca. 180 fungal taxa of the genus Glomeromycota (Smith and Read, 2008). In AM associations, fungal hyphae penetrate cortical cells of plant fine roots and develop hyphal coils and arbuscles to increase the surface area for the exchange of nutrient minerals and water with carbon. Several fungal species also form vesicles, structures used as lipid storages (van Aarle \& Olsson 2003).

\subsection{Ectomycorrhiza}

The dominating mycorrhizal type in boreal and temperate forests is ectomycorrhiza (EM). Fossile records of EM originate from 50-52 million years ago (Beimforde et al. 2011, LePage et al. 1997), but presumably EM evolved together with gymnosperms and exist since 190 million years (Taylor et al. 2009). EM associations are formed by estimated 7000-10 000 fungal taxa and by 8000 plant taxa (Taylor \& Alexander 2005). Even though only a small fraction of terrestrial plants form EM symbioses, they include numerous ecologically and economically important tree species (Taylor and Alexander, 2005).

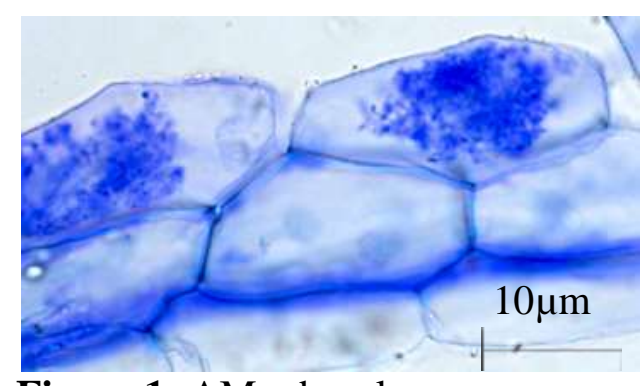

Figure 1: AM arbuscles

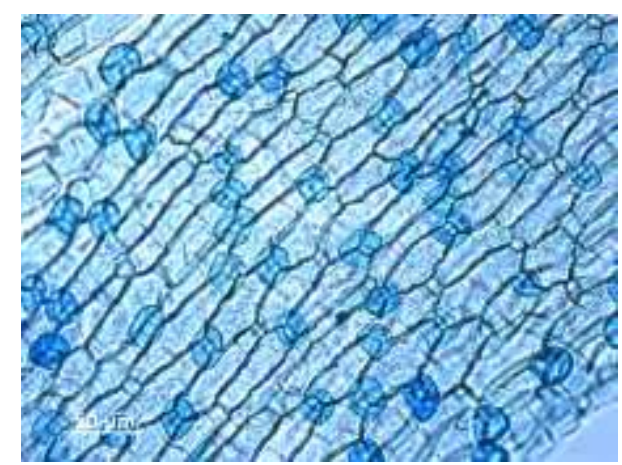

Figure 2: AM vesicles and hyphae

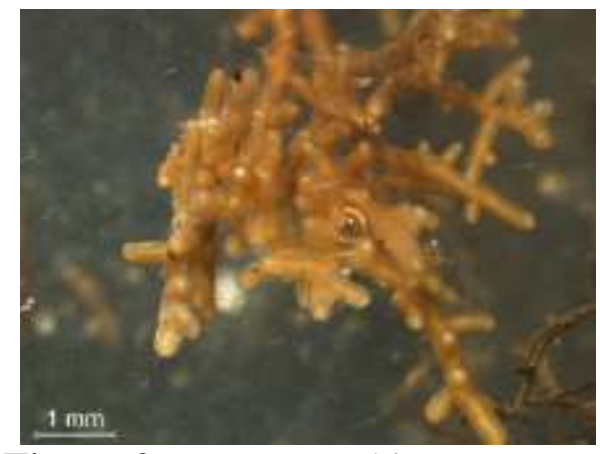

Figure 3: EM mycorrhiza

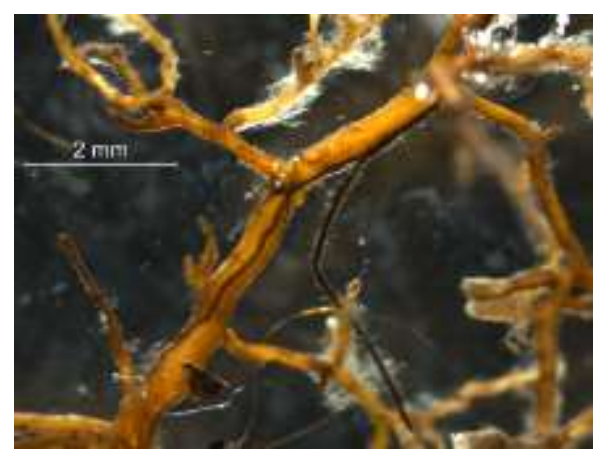

Figure 4: EM rhizomorphs on beech fine roots 
EMs have an often well developed periradical phase, present as a hyphal mantle that covers the outside of the fine root tips and has a characteristic appearance, so called morphotype. The intraradical part of EMs consists of the Hartig net, an interface for plant carbon and nutrient exchange (Corrêa et al. 2012). The extraradical hyphae emanate from the mantle into the surrounding soil. They can greatly differ in structure, abundance and length and in some EM form vessel like structures, so called rhizomorphs, which serve the long distance nutrient and water transport (Agerer 1990).

\subsection{Functions of mycorrhizal association}

Mycorrhizal fungi provide their host plant with nutrients and water and in exchange up to $22 \%$ of the plant assimilated C (Hobbie 2006). When the allocation of recent photpassimilates to roots is restricted, trees have been shown to supply mycorrhiza from root $\mathrm{C}$ storages (Appendix 2). Recent experiments with ${ }^{13} \mathrm{CO}_{2},{ }^{15} \mathrm{~N}$ and ${ }^{32} \mathrm{P}$ labelling (Fellbaum et al. 2012, Kiers et al. 2011) and a meta analysis of published data (Corrêa et al. 2012) showed that in $\mathrm{AM}$ and EM associations, both plant and fungus control the nutrient and $\mathrm{C}$ exchange. When colonized with multiple fungi, plants provide beneficial mycorrhizal partners with more $\mathrm{C}$ than unprofitable partners. In turn, fungi can drive the symbiosis by increased nutrient transfer to roots containing higher $\mathrm{C}$ concentrations. The bi-directional control presumably results in a fair reciprocal transfer of nutrients and carbon (Corrêa et al. 2012, Kiers et al. 2011).

\section{Nitrogen and phosphorus in plant nutrition}

The most plant growth limiting factor in temperate forests is nitrogen (N) (Rennenberg et al. 1998). It is an essential component of numerous organic compounds of plant cells, such as amino acids, proteins and nucleid acids. Plants acquire $\mathrm{N}$ mainly from two sources: from soil, through mineralization of organic matter, as well as through natural and anthropogenic $\mathrm{N}$ deposition, and from atmosphere through symbiotic $\mathrm{N}_{2}$ fixation (Vance 2001). In forest soils, the main fraction of $\mathrm{N}$ occurs in organic compounds, such as leaf litter, dead roots and soil organisms. Only a small fraction of soil $\mathrm{N}$ is present as ammonium $\left(\mathrm{NH}_{4}{ }^{+}\right)$, nitrate $\left(\mathrm{NO}_{3}{ }^{-}\right)$or in form of simple amino acids that can be directly taken up by plant roots (Näsholm et al. 2009). Tree species differ in their preferences to distinct $N$ forms (Schulz et al. 2011). Whereas coniferous tree species are generally considered to prefer $\mathrm{NO}_{3}{ }^{-}$over $\mathrm{NH}_{4}{ }^{+}$, in deciduous species considerable species specific differences and contradictory results within one species have been reported (Dannenmann et al. 2009). In general, the uptake of $\mathrm{NH}_{4}{ }^{+}$is considered as 
more cost efficient, whereas $\mathrm{NO}_{3}{ }^{-}$might be more plant available due to its higher diffusion rate and low absorption to soil particles (Darrah et al. 1983).

The second most plant growth limiting macronutrient in temperate forests is phosphorous $(\mathrm{P})$ (Cairney 2011). For plants it is essential as a structural component of proteins, enzymes and nucleid acids, with numerous functions in plant metabolism and growth, such as photosynthesis, respiration, as well as energy production, storage and transfer. In soils, both inorganic and organic forms of $\mathrm{P}$ exist. Organic $\mathrm{P}\left(\mathrm{P}_{\mathrm{o}}\right)$ is mainly present as phosphate monoesters, phosphate diesters and inositol phosphates, whereas inorganic $\mathrm{P}\left(\mathrm{P}_{\mathrm{i}}\right)$ is mainly present in form of mineral and dissolved phosphates (Schachtman et al. 1998). Although bound $\mathrm{P}$ is relatively abundant in many soils, the main portion of $\mathrm{P}$ is not available for plant uptake due to the high reactivity with other chemical and biological compounds (White and Hammond 2005). $\mathrm{P}$ availability varies with factors such as soil age, rates of mineral $\mathrm{P}_{\mathrm{i}}$ weathering, precipitation reactions with cations, rates of decomposition and immobilization in microbes and plants (Lambers et al. 2008). In Central European forests the amount of organic bound $\mathrm{P}$ increases with increasing tree species diversity whereas the ratio of mineral $\mathrm{P}$ is relatively constant irrespective of the tree species diversity (Talkner et al. 2009).

Plants take up mainly inorganic orthophosphate $\mathrm{P} i$, which occurs in low concentrations $(10 \mu \mathrm{M})$ in the soil solution (Schachtman et al. 1998). The optimal Pi uptake of most plants is recorded at soil $\mathrm{pH}$ between 6.0 and 5.0. Under these conditions $\mathrm{P} i$ mainly occurs as $\mathrm{H}_{2} \mathrm{PO}_{4}{ }^{-}$. Due to the low diffusion rate $\left(10^{-12}\right.$ to $\left.10^{-15} \mathrm{~m}^{2} \mathrm{~s}^{-1}\right)$ of $\mathrm{P} i$ in soil solutions, the phosphorous concentration in root near rhizosphere is rapidly depleted. In order to maintain plant internal $\mathrm{P}$ balance, plants store and recycle P (Schachtman et al. 1998).

Plants have evolved different strategies to overcome the nutrient depletion in the rhizosphere. These include the modification of root growth and architecture (Curt et al. 2005, Jacob et al. 2012), influence on soil chemical properties, which include acidification through proton extrusion and the release of root exudates (organic acids), as well as influencing soil microbial activity (Fender et al. 2012, Richardson et al. 2009). However, the most important strategy to overcome nutrient transport limitation in the depletion zone is the mycorrhizal association (Smith et al. 2001).

\section{Functions of $\mathrm{AM}$ and $\mathrm{EM}$ in plant $\mathrm{P}$ and $\mathrm{N}$ acquisition}

Numerous mycorrhizal fungi have been shown to substantially enhance both plant $\mathrm{N}$ and $\mathrm{P}$ uptake (Cairney 2011, Plassard \& Dell 2010, Smith \& Read 2008). The host plant receive 
nutrients via mobilisation and absorption by fungal mycelia, translocation through fungal hyphae to the fungus-root interface and transfer across the fungus-root interface (Nehls et al. 2007). Both AM and EM fungi produce extraradical mycelia, that formed by AM can reach soil areas of several cm (Drew et al. 2003, Eissenstat 1990) and that by EM up to several meters (Fiore-Donno \& Martin 2001) from root surface. Thus, both fungal types extend far beyond the nutrient depletion zone of the rhizosphere and generate an efficient network of nutrient uptake. Mycorrhizal root tips and hyphae produce a range of exudates that serve the nutrient release by mineral weathering (Landeweert et al. 2001), mineralisation of organic polymers (Durall et al. 1994, Read \& Perez-Moreno 2003), and that are also required for nutrient uptake processes, metal detoxification and antimicrobial defence. Exudates consist mainly of low molecular weight organic acids, saccarides, amino acids and peptides but EM root tips also release fatty acids, polymeric carbohydrates and different enzymes into the soil (Courty et al. 2005, Gadd 2007).

In temperate forests, EM fungi contribute up to $80 \%$ of the host plant $\mathrm{N}$ (van der Heijden et al. 2008). EMs have been shown to be able to use both mineral $\mathrm{N}$ sources nitrate $\left(\mathrm{NO}_{3}\right)$ (Nygren et al. 2008) and ammonium ( $\left.\mathrm{NH}_{4}\right)$, most likely with a preference to ammonium, if both $\mathrm{N}$ forms are available (Finlay et al. 1989, Smith and Read 2008). Furthermore, EMs have been reported to use a range of organic compounds, such as proteins and nucleic acids, as $\mathrm{N}$ sources (Marmeisse et al. 2004). They secrete extracellular proteinases and peptidases that effectively hydrolyse organic $\mathrm{N}$ sources to amino acids, which can be absorbed by the fungus (Chalot \& Brun 1998, Nygren et al. 2008). The production of extracellular phosphormonoesterases and phosphodiesterases has been reported, as well as that of hydrolytic enzymes such as cellulases and hemicellulases (Nygren \& Rosling 2009). These enzymes might serve the penetration to dead organic material in soil for uptake of sequestered mineral nutrients (Morel et al. 2006, Nygren \& Rosling 2009).

AM fungi have been shown to take up and transport $\mathrm{NO}_{3}{ }^{-}$(Govindarajulu et al. 2005, Tobar et al. 1994) and $\mathrm{NH}_{4}{ }^{+}$(Jin et al. 2005, Peréz-Tienda et al. 2012). The uptake of $\mathrm{N}$ from organic sources has been reported (Hawkins et al. 2000, Hodge \& Fitter 2010), however it is not clear in which form AM acquire $\mathrm{N}$ from organic compounds (Hodge 2001, Leigh et al. 2009). AM fungi mainly take up mineral $\mathrm{P}$, but some species have been shown to extract $\mathrm{P}$ from organic sources with extracellular phosphatases (Hodge \& Fitter 2010, Jayachandran et al. 1992). Also EM are able to use both mineral and organic P sources (Cairney 2011). The absorption 
of $\mathrm{P}_{\mathrm{i}}$ is maximized by high affinity transporters of the types $\mathrm{P}_{\mathrm{i}}: \mathrm{H}^{+}$and $\mathrm{P}_{\mathrm{i}}: \mathrm{Na}^{+}$(Harrison et al. 2002, Plassard \& Dell 2010). Several AM and EM putative $P_{i}$ transporter genes have been reported, that are mainly expressed in extraradical mycelium during the symbiosis (Harrison \& van Buuren 1995, Martin et al. 2008, Tatry et al. 2009).

In mycorrhizal hyphae, $\mathrm{N}$ is transported mainly as amino acids and $\mathrm{NH}_{4}{ }^{+}, \mathrm{P}_{\text {presumably as }} \mathrm{P}_{\mathrm{i}}$ (Chalot et al. 2006, Müller et al. 2007). P absorption is regulated by phosphate demand of the host plant. Plant $\mathrm{P}$ demand is reflected by plant $\mathrm{P}$ status, as well as by the concentration of hyphal polyphosphates, which serve as $\mathrm{P}_{\mathrm{i}}$ storage pools (Bücking et al. 1999, Bücking et al. 2000, Cairney \& Smith 1992, Finlay 1989). At the fungus-root interface, the nutrients are transferred through efflux across the fungal plasma membrane (Bücking et al. 1999). Subsequently, nutrients are absorbed from the apoplasm of the fungus-root interface across the plasma membrane of the host root cell (Nehls et al. 2007). The apoplasmic compartment serves the control of local chemical and physical properties of the plant-fungus interface. This presumably results in an equal control of the exchange by both fungus and host plant (Corrêa et al. 2012, Kiers et al. 2011, Nehls et al. 2007).

\section{Plant interactions}

Plant competition occurs when individuals of same species (intraspecific) or different species (interspecific) compete for the same resource, such as light, nutrients or space. Interactions among plant individuals are usually size-asymmetric, which means a resource pre-emption by a larger individual, usually measured by disproportional size advantage of larger individuals of a population. In the aboveground compartment, this is comprehensible, since the main limiting resource is light. A taller plant can pre-empt light from shorter neighbours. Therefore, already a small size difference can offer a considerable competitive advantage. Similarly, investigations of fine root biomass distributions and competitive interactions in the field, which were investigated by soil core analysis and root growth chambers with isolated but intact fine root endings of mature trees, a markedly asymmetric belowground competition has been demonstrated in temperate forests (Leuschner et al. 2001, Rewald \& Leuschner 2009). Since mycorrhizal interactions tightly associate with plant interactions (Jacob et al. 2012), it is important to consider them as a part of the plant interactions.

\section{Mycorrhizal fungi in ecological interactions}

\subsection{Mycorrhizal fungi in plant interactions}


Current research is addressing the question whether mycorrhizal fungi influence the outcome of plant competitive interactions. This is particularly important, not only to understand the interactions of plants in natural ecosystems, but also the effects of global change, such as the dispersal of invasive aliens on ecosystem structure and function (Dawson et al. 2012). The mycorrhizal status has a great impact on plant competition. Experiments with AM plants showed that usually plant size decreases without mycorrhizal association. This is based on the potential inability of mycorrhiza forming plants to effective use soil resources in the absence of mycorrhizal colonization (Facelli et al. 1999, van der Heijden et al. 2003). In mycorrhizal association the level of interplant competition increases considerably with enhanced use of available soil volume.

Also mycorrhizal types EM or AM might differently modify plant interactions. Aerts (2002) suggested a theoretical model of plant competition for two nutrients between plant species with different mycorrhizal types, based on Tilman's model (Tilman 1982).
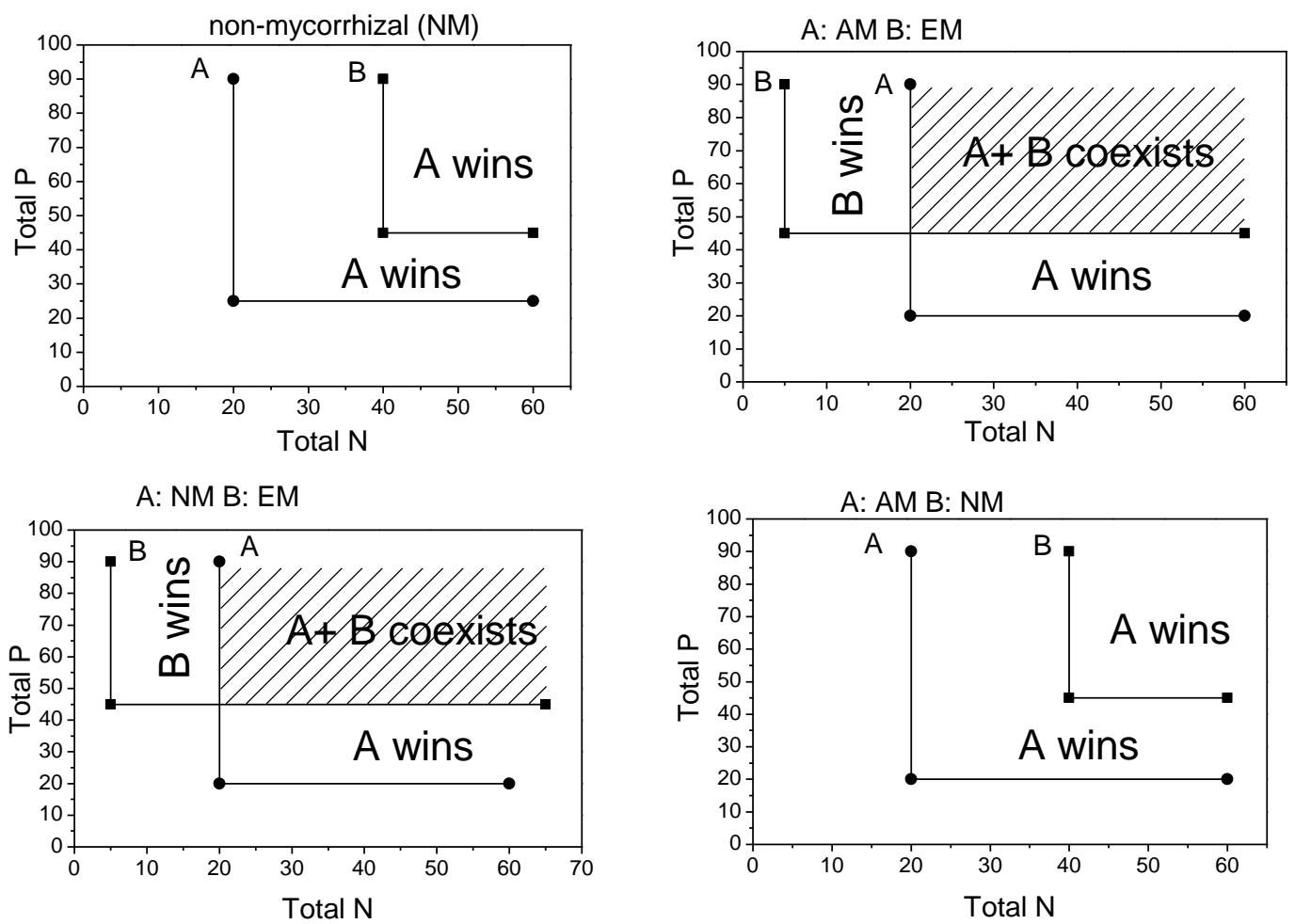

Figure 5: A hypothetical model to predict the effect of mycorrhizal colonization on plant coexistence in temperate forests based on Tilman's $\mathrm{R}^{*}$ model. The species that can grow on the lowest resource concentration $\left(\mathrm{R}^{*}\right)$ is competitively superior to the other species. In a nonmycorrhizal (NM) situation the plant species associated with AM fungi (A) out-competes the plant species associated with EM fungi (B), because of its higher uptake capacity for both nitrogen $(\mathrm{N})$ and phosphorus $(\mathrm{P})$. In the mycorrhizal situation a co-existence is possible because of the increased capacity of the plant species with EM to take up $\mathrm{N}$ and a higher capacity of the plant associated with AM fungi to take up P. Adapted from (Aerts 2002). 
The model is based on the assumption that nutrient utilization of two resources can lead to niche differentiation or out-competition between species. The species, which can reduce the resource to the lowest level and maintain growth, wins the competition. Co-existence is possible, when the growth of the species is differentially limited by the resources. Figure 5 demonstrates the suggested role of mycorrhizal type on plant interactions. In the absence of mycorrhizal colonisation, plant species associated with AM fungi is predicted to have a competitive advantage over plant species associated with EM fungi due to their presumably faster N and P uptake (Schulz et al. 2011, Stadler et al. 1993). The mycorrhizal colonization changes the situation. The suggested higher uptake capacity of EM for N, and AM for P leds to an increased $\mathrm{P}$ status of plant associated with AM fungi and increased $\mathrm{N}$ status of plant associated with EM fungi. According to Tilman's model, both species can co-exist under these conditions.

The shift between co-existence and competition however varies with the total amount of the nutrient acquisition. Moreover, a number of influencing factors, such as plant species identity and species assemblages of root colonizing fungi have a great influence on plant performance (van der Heijden et al. 2003, van der Heijden et al. 1998). In an experiment with the AM forming plant species Hieracium pilosella, Bromus erectus, and Festuca ovina and four AM fungi, van der Heiden et al. (1998) demonstrated that plant species differ in their dependency on AM. This was reflected by the differing growth response of plant species on mycorrhizal colonisation, as well as by different effects of both AM species identity and species assemblages on several plant growth variables. Mycorrhizal diversity might also acts as an insurance to sustain plant productivity under changing environmental conditions. In a greenhouse experiment (Wagg et al. 2011) demonstrated that under nutrient limited conditions high number of AM mycorrhizal species relaxed the interspecific competition by reducing the growth suppression of the competitively weaker plant species. In nutrient-rich systems, the mixture of four AM fungal species was equally beneficial for the plant productivity as the most beneficial mycorrhizal fungal species in low nutrient system (Wagg et al. 2011).

\subsection{Mycorrhizal networks}

Both AM and EM fungi form simultaneous associations with trees of one or more taxa (Bent et al. 2011). These mycorrhizal networks $(\mathrm{MN})$ are able to transport nutrients and carbon between tree individuals, and create facilitative effects of nutrient and water partitioning. This 
might be particularly important to relax the aboveground competition between mature plants and seedlings (Teste \& Simard 2008). In a review of 60 cases, in which seedlings and larger plants were grown together, van der Heijden and Horton (2009) demonstrated that MN promoted seedling growth in $48 \%$ of the cases, whereas in $27 \%$ cases the effect of MN was neutral and in $25 \%$ cases negative (van der Heijden \& Horton 2009). Generally, plants with EM benefitted from the MN, while the effects of AM association varied (van der Heijden \& Horton 2009). The type of mycorrhizal association might be particularly important, thus MN can strongly affect the growth and survival of plant species excluded from the prevailing MN (Booth 2004) and finally enhance the dominance of plants with one mycorrhizal type over another (McGuire 2007).

\subsection{Trophic interactions with soil fauna}

Mycorrhiza serve as an important channel of plant mediated carbon to soil food web (Pollierer et al. 2007). The use of ${ }^{13} \mathrm{CO}_{2}$ gas labelling has currently confirmed $\mathrm{C}$ from recent photoassimilates as the most important $\mathrm{C}$ source of soil animals. Besides living or dead roots and root exudates, EM hyphae presumably contribute in a considerable manner to the nutrition of soil animals (Landeweert et al. 2001).

Spore findings of EM in guts of arthropod fungivores (mites, springtails, millipedes, beetles, fly larvae) and predators (centipedes) suggest that diverse soil animals feed on mycorrhiza and serve the spore dispersal of belowground fruiting species (Lilleskov \& Bruns 2005). Feeding experiments with axenic fungal cultures have shown that soil animal species feed selectively on distinct fungal species (Hiol et al. 1994, Scheu \& Simmerling 2004). However, due to differences in EM metabolism in the symbiotic stage and the large variety of EM species in natural communities (Lang \& Polle 2011), feeding choice experiments can hardly reflect animal behaviour under natural conditions. Currently, no firm proof for the mycorrhizal structures as primary diet of certain soil animals exists (Högberg et al. 2010, Pollierer et al. 2007). Furthermore other kinds of interaction, such as interactions between mycorrhizal and saprophytic fungi (Cairney \& Meharg 2002, Mougel et al. 2006) or soil bacteria (Frey-Klett et al. 2007) occur. However, they are not considered in this thesis, since the research here focused on interactions with soil fauna. 
6 Ecological characteristics of beech

(Fagus sylvatica) and ash (Fraxinus excelsior)

Beech (Fagus sylvatica) is under natural conditions, with few exceptions, the dominating tree species in monocultures and mixed forest stands in Central Europe. Currently, beech comprises approximately $30 \%$ of the forest area in Germany (www. bundeswaldinventur.de).

Beech develops a typical heart root system with a markedly dense fine root fraction. The rooting depth depends strongly on the aeration of the soil. The main rooting direction is downwards, at an angle of ca. $45^{\circ}$ (Rust \& Savill 2000). The beech roots divide into fine rootlets and end in fine tips. Beech roots do not extend very far and the rooting is very intensive, especially in the top 5-10 cm (Rust \& Savill 2000).

Beech has wide habitat amplitude. It favours habitats with Atlantic climatic characters; moist, warm conditions, relatively warm winters and high precipitation, avoids stagnant moisture and too

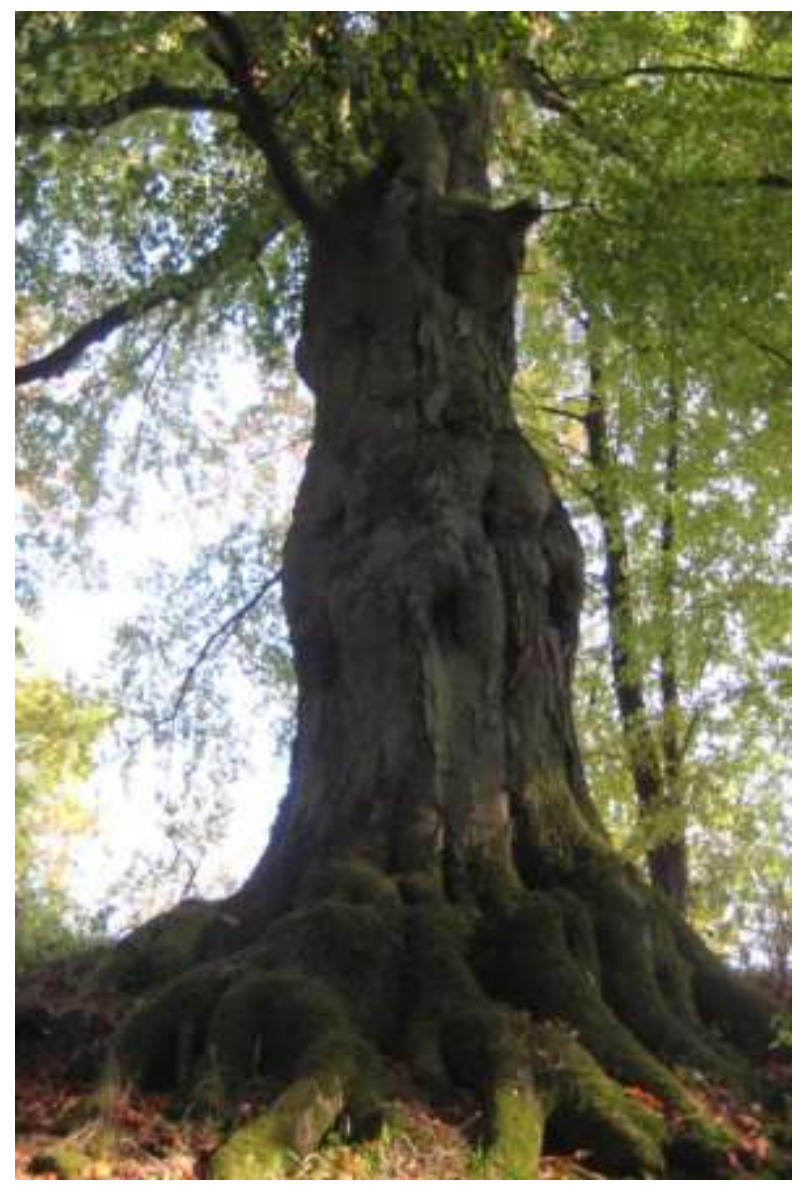

Figure 6: Beech (Fagus sylvatica)

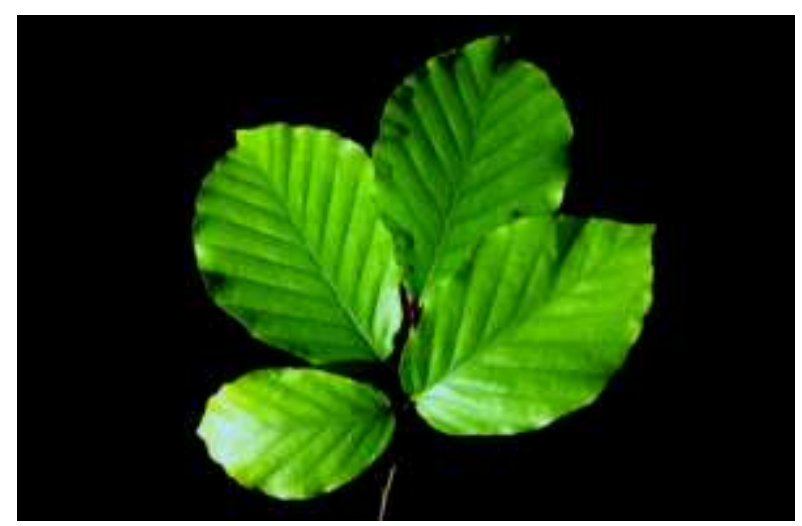

Figure 7: Beech leaf dry soils (Ellenberg \& Leuschner 2010). Especially in a young age beech is sensitive to winter frost, late frost, heat and dryness (Geßler et al. 2007). The best growth is reached in moist and nutrient rich soils. 
Ash (Fraxinus excelsior) is a common deciduous tree species in entire Europe, with the exception of north Scandinavia and south Spain. In Germany ash is found in all areas, in the low mountain range up to $800 \mathrm{~m}$ and in the Alps up to $1350 \mathrm{~m}$ (Ellenberg \& Leuschner 2010).

Ash root systems are superficial but far reaching. It has a strong horizontal root system that sends laterals vertically downwards. The superficial rooting is very intensive and dominates the upper $0-5 \mathrm{~cm}$ of the soil profile. The fine roots usually end sud-denly and blunty (Rust and Savill, 2000). With its root system ash is able to grow in compact and wet soils. In wet soil the fine roots grow preferentially in the patches with higher aeration.

Ash has a high demand on soil nutrient richness and humidity, though it occurs on a wide range of soil types, particularly at basic (pH 6-7), calcarous soils. The optimal growth is reached only on fertile, $\mathrm{pH}$ neutral, deep, moist and freely draining soils (Kerr \& Cahalan 2004).

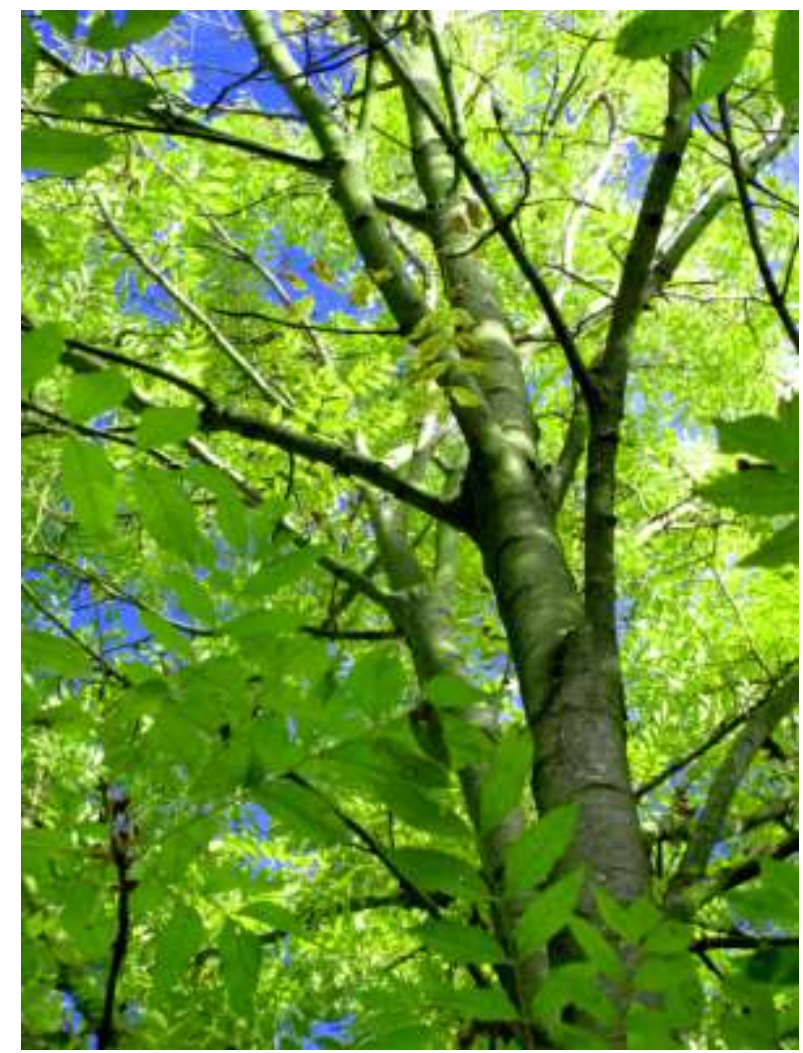

Figure 8: Ash (Fraxinus excelsior)

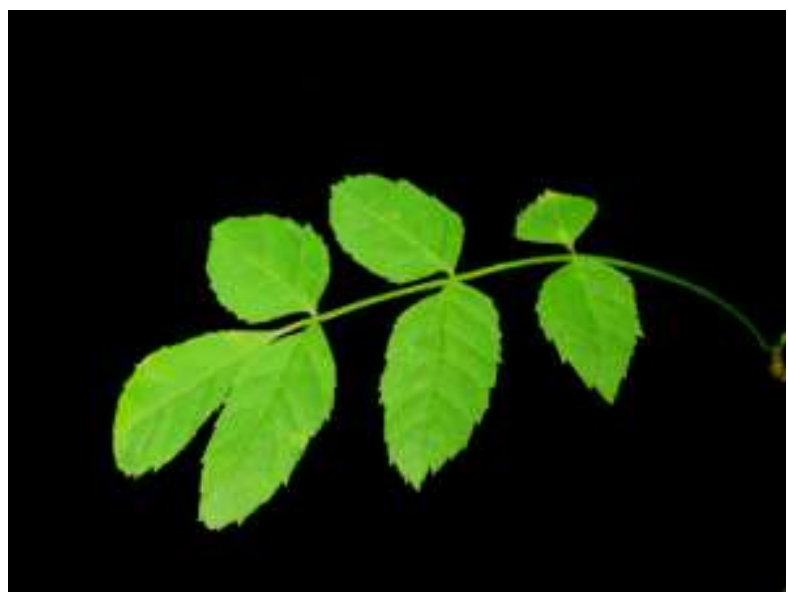

Figure 9: Ash leaf

Its occurrence on sites which are marginal or less optimal is probably due to competition with other species on better sites, frequently mediated by forest management. 
Beech and ash differ in their light demands. Especially in the juvenile stage, beech tolerates shade (Emborg 1998). Its growth in shade is plagiotrophic, indicating a horizontal lightforaging strategy (Petritan 2009). The growth of ash follows a cap-growth strategy, characterised by a constant growth response to increasing light and an inability to strongly reduce the growth rate in deep shade (Emborg 1998, Petritan 2009).

In mixed stands of ash and beech the relative strength of plant interactions varies with stand development. The distribution of ash saplings is mainly influenced by the competition for light, whereas the interspecific competition for water strongly limits the growth and survival of beech (Rust \& Savill 2000). Compared with beech, ash is more tolerant to drought (Rust \& Savill 2000). In contrast, beech saplings tolerate shade better than ash. In mixed stands ash dominates the canopy in the first $(\sim 60)$ years of growth due to its faster growth. In the biostatic phase of the forest development, the dominance shifts from ash to beech. From now on beech is able to shade ash and reduce its biomass productivity (Emborg 1998). Interesingly, in age between 100 and 200 years, the upper $20 \mathrm{~cm}$ of the soil is apparently dominated by ash roots (Jacob et al. 2012, Rust \& Savill 2000).

It is well known that different tree species require different $\mathrm{N}$ and $\mathrm{P}$ concentrations in their leaves for optimal functioning and growth (Güsewell 2004). According to foliar threshold values, normal ranges of foliar $\mathrm{N}$ and $\mathrm{P}$ for beech are $18.7-23.2 \mathrm{mg} \mathrm{g}^{-1}$ and $1.2-1.9 \mathrm{mg} \mathrm{g}^{-1}$ respectively (Mellert \& Göttlein 2012). Corresponding values for ash are $23-28 \mathrm{mg} \mathrm{N} \mathrm{g}^{-1} \mathrm{dwt}$ and 1.4-1.6 mg P g-1 dwt, respectively (Kopinga \& van den Burg 1995). The leaf $\mathrm{N}$ and $\mathrm{P}$ concentrations have been suggested to reflect the availability of these nutrients in certain habitats and therefore used as an index of the nutrition (Berger \& Glatzel 2001, Güsewell 2004). At sufficient nutrient availability the $\mathrm{N}$ and $\mathrm{P}$ threshold values are reflected by leaf N/P ratios of 12.2-15.6 for beech, and 16.4-17.5 for ash. Contradictory results about the preference for mineral $\mathrm{N}$ forms in ash and beech exist. Geßler et al. (1998) reported a preference of beech for $\mathrm{NH}_{4}{ }^{+}$both in the field and under laboratory conditions, whereas others have demonstrated that beech trees to prefer $\mathrm{NO}_{3}{ }^{-}$over $\mathrm{NH}_{4}{ }^{+}$(Dannenmann et al. 2009, Schulz et al. 2011, Simon et al. 2011). Reports for ash suggest a moderate preference for $\mathrm{NH}_{4}{ }^{+}$over $\mathrm{NO}_{3}{ }^{-}$(Stadler et al. 1993), preference for $\mathrm{NO}_{3}{ }^{-}$over $\mathrm{NH}_{4}{ }^{+}$(Schulz et al. 2011), or no preference for the given $\mathrm{N}$ forms (Jacob et al. unpublished). These observations however do not consider the role of mycorrhizal colonization, whose changes may partially explain the variability of the results within one tree species. 


\section{Objectives}

This thesis focuses on the question how mycorrhizal fungi relate to plant competitive interactions and multitrophic interactions in the soil food web.

The following research questions guided the present thesis:

- Ash and beech often co-occure in mixed temperate forests. Does plant competition for nutrients relate to root colonizing mycorrhizal fungi? Concerning this research question, the nutrient uptake of beech and ash seedlings was studied in conspecific and heterospecific mixtures. The path of inorganic phosphorus, and nitrogen were studied with radioactive $\left({ }^{32} \mathrm{P},{ }^{33} \mathrm{P}\right)$ and stable $\left({ }^{15} \mathrm{~N}\right)$ tracers (Chapter 2 and 3$)$.

- Interspecific interactions between ash and beech have often been compared without considering the associated mycorrhizal fungi on tree interactions. Which role do different EM fungi have in the nutrient acquisition of beech? In order to discover species differences of EM fungi, their contribution on nutrient acquisition of beech was studied. Uptake of mineral P (Chapter 2) and mineral N (Chapter 3) was studied in non-mycorrhizal root tips as well as in root tips colonized with different EM species of beech and compared with the nutrient accumulation in fine roots of ash.

- The effects of tree species interactions on simultaneous $\mathrm{N}$ and $\mathrm{P}$ accumulation are barely examined. What relationship do $\mathrm{N}$ and $\mathrm{P}$ accumulation of ash and beech have in species interactions, and how do $\mathrm{N}$ and $\mathrm{P}$ accumulation relate in different EM species?

- Mycorrhizal fungi are presumably an important channel of plant $\mathrm{C}$ into soil food web. We studied the paths of plant $\mathrm{C}$ via mycorrhizal fungi to soil animal food web and soil-derived $\mathrm{N}$ to plants. For this reason, natural regeneration of beech from Hainich National Park with intact mycorrhizal and soil animal community was grown in mesocosms for one growth season and labelled with ${ }^{13} \mathrm{CO}_{2}$ and ${ }^{15} \mathrm{NO}_{3}{ }^{15} \mathrm{NH}_{4}$ (Chapter 4).

The analyses of the impact of mycorrhizal fungi on nutrient and $\mathrm{C}$ fluxes between trees and soil food web will provide basic information that so far has been lacking. In addition, this thesis may give information about factors, which influence the co-occurrence of tree species with differing mycorrhizal types. 


\section{References}

Aerts, R. (2002), 'The role of various types of mycorrhizal fungi in nutrient cycling and plant competition', In: van der Heijden, M. \& Sanders, I. E. (Eds) Mycorrhizal ecology (Ecological Studies: Analysis \& Synthesis), Springer, Berlin; 117-133.

Agerer, R. (1990), 'Exploration types of ectomycorrhizae a proposal to classify ectomycorrhizal mycelial systems according to their patterns of differentiation and putative ecological importance', Mycorrhiza 11(2), 107-114.

Bücking, H. \& Heyser, W. (1999), 'Microautoradiographic localization of phosphate and carbohydrates in mycorrhizal roots of Populus tremula x Populus alba and the implications for transfer processes in ectomycorrhizal associations', Tree Physiology 21(2-3), 101-107.

Bücking, H. \& Heyser, W. (2000), 'Subcellular compartmentation of elements in nonmycorrhizal and mycorrhizal roots of Pinus sylvestris: an X-ray microanalytical study. I. the distribution of phosphate', New Phytologist 145(2), 311-320.

Beimforde, C., Schäfer, N., Dörfelt, H., Nascimbene, P.C., Singh, H., Heinrichs, J., Reitner, J., Rana, R.S. \& Schmidt, A.R. (2011), 'Ectomycorrhizas from a Lower Eocene angiosperm forest', New Phytologist 192(4),988-996.

Bent, E., Kiekel, P., Brenton, R. \& Taylor, D. L. (2011), 'Root-associated ectomycorrhizal fungi shared by various boreal forest seedlings naturally regenerating after a fire in Interior Alaska and correlation of different fungi with host growth responses.', Applied and Environmental Microbiology 77(10), 3351-3359.

Berger, T. W. \& Glatzel, G. (2001), 'Response of Quercus petraea seedlings to nitrogen fertilization', Forest Ecology and Management 149(1-3), 1-14.

Booth, M. G. (2004), 'Mycorrhizal networks mediate overstorey-understorey competition in a temperate forest', Ecology Letters 7(7), 538-546.

Bundeswaldinventur http://www.bundeswaldinventur.de. Accessed 2004, last access 28 November 2012

Cairney, J. (2011), 'Ectomycorrhizal fungi: the symbiotic route to the root for phosphorus in forest soils', Plant and Soil 344, 51-71.

Cairney, J. W. \& Meharg, A. A. (2002), 'Interactions between ectomycorrhizal fungi and soil saprotrophs: implications for decomposition of organic matter in soils and degradation of organic pollutants in the rhizosphere', Canadian Journal of Botany 80(8), 803-809.

Cairney, J. \& Smith, S. (1992), 'Influence of intracellular phosphorus concentration on phosphate absorption by the ectomycorrhizal basidiomycete Pisolithus tinctorius', Mycological Research 96(8), 673 - 676. 
Chalot, M., Blaudez, D. \& Brun, A. (2006), 'Ammonia: a candidate for nitrogen transfer at the mycorrhizal interface', Trends in Plant Science 11(6), 263-266.

Chalot, M. \& Brun, A. (1998), 'Physiology of organic nitrogen acquisition by ectomycorrhizal fungi and ectomycorrhizas.', FEMS Microbiology Reviews 22(1), 21-44.

Cornelissen, J., R. Aerts, B. C., Werger, M. \& van der Heijden, M. (2001), 'Carbon cycling traits of plant species are linked with mycorrhizal strategy', Oecologia 129(4), 611619.

Corrêa, A., Gurevitch, J., Martins-Loução, M. A. \& Cruz, C. (2012), 'C allocation to the fungus is not a cost to the plant in ectomycorrhizae', Oikos 121(3), 449-463.

Courty, P.-E., Pritsch, K., Schloter, M., Hartmann, A. \& Garbaye, J. (2005), 'Activity profiling of ectomycorrhiza communities in two forest soils using multiple enzymatic tests', New Phytologist 167(1), 309-319.

Curt, T., Colla, L., Prévostoa, B., Balandiera, P. \& Kunstler, G. (2005), 'Plasticity in growth, biomass allocation and root morphology in beech seedlings as induced by irradiance and herbaceous competition', Annals of Forest Science 62(1), 51-60.

Dannenmann, M., Simon, J., Gasche, R., Holst, J., Naumann, P. S., Ögel-Knabner, I., Knicker, H., Mayer, H., Schloter, M., Pena, R., Polle, A., Rennenberg, H. \& Papen, H. (2009), 'Tree girdling provides insight on the role of labile carbon in nitrogen partitioning between soil microorganisms and adult European beech', Soil Biology and Biochemistry 41(8), 1622-1631.

Darrah, P. R., Nye, P. H. \& White, R. E. (1983), 'Diffusion of $\mathrm{NH}_{4}{ }^{+}$and $\mathrm{NO}_{3}{ }^{-}$, mineralized from organic $\mathrm{n}$ in soil', Journal of Soil Science 34, 693-707.

Dawson, W., Fischer, M., van Kleunen, M. \& Suding, K. (2012), 'Common and rare plant species respond differently to fertilisation and competition, whether they are alien or native', Ecology Letters.

Drew, E., Murray, R., Smith, S. \& Jakobsen, I. (2003), 'Beyond the rhizosphere: growth and function of arbuscular mycorrhizal external hyphae in sands of varying pore sizes', Plant and Soil 251, 105-114.

Dučić , T., Berthold, D., Langenfeld-Heyser, R., Beese, F. \& Polle, A. (2009), 'Mycorrhizal communities in relation to biomass production and nutrient use efficiency in two varieties of Douglas fir (Pseudotsuga menziesii var. menziesii and var. glauca) in different forest soils', Soil Biology \& Biochemistry 41, 742-753.

Durall, D. M., Todd, A. W. \& Trappe, J. M. (1994), 'Decomposition of ${ }^{14}$ C-labelled substrates by ectomycorrhizal fungi in association with Douglas fir', New Phytologist 127(4), $725-729$. 
Eissenstat, D. M. (1990), 'A comparison of phosphorus and nitrogen transfer between plants of different phosphorus status', Oecologia 82, 342-347.

Ellenberg, H. \& Leuschner, C. (2010), Vegetation Mitteleuropas mit den Alpen, Ulmer Verlag, Stuttgart.

Emborg, J. (1998), 'Understorey light conditions and regeneration with respect to the structural dynamics of a near-natural temperate deciduous forest in Denmark', Forest Ecology and Management 106(2 -3), 83-95.

Facelli, E., Facelli, J. M., Smith, S. E. \& McLaughlin, M. J. (1999), 'Interactive effects of arbuscular mycorrhizal symbiosis, intraspecific competition and resource availability on Trifolium subterraneum cv. mt. Barker', New Phytologist 141(3), 535-547.

Fellbaum, C. R., Gachomo, E. W., Beesetty, Y., Choudhari, S., Strahan, G. D., Pfeffer, P. E., Kiers, E. T. \& Bücking, H. (2012), 'Carbon availability triggers fungal nitrogen uptake and transport in arbuscular mycorrhizal symbiosis.', Proceedings of the National Academy of Sciences of the United States of America 109(7), 2666-2671.

Fender, A.-C., Gansert, D., Jungkunst, H. F., Fiedler, S., Beyer, F., Schützenmeister, K., Thiele, B., Valtanen, K., Polle, A. \& Leuschner, C. (2012), 'Root-induced tree species effects on the source/sink strength for greenhouse gases $\left(\mathrm{CH}_{4}, \mathrm{~N}_{2} \mathrm{O}\right.$ and $\left.\mathrm{CO}_{2}\right)$ of a temperate deciduous forest soil', Soil Biology and Biochemistry. In press. Online access 31 August 2012.

Finlay, R. D. (1989), 'Functional aspects of phosphorus uptake and carbon translocation in incompatible ectomycorrhizal associations between Pinus sylvestris and Suillus grevillei and Boletinus cauipes', New Phytologist 112(2), 185-192.

Fiore-Donno, A.-M. \& Martin, F. (2001), 'Populations of ectomycorrhizal Laccaria amethystina and Xerocomus spp. show contrasting colonization patterns in a mixed forest', New Phytologist 152(3), 533-542.

Frey-Klett, P., Garbaye, J. \& Tarkka, M. (2007), 'The mycorrhiza helper bacteria revisited', New Phytologist 176(1), 22-36.

Gadd, G. M. (2007), 'Geomycology: biogeochemical transformations of rocks, minerals, metals and radionuclides by fungi, bioweathering and bioremediation', Mycological Research 111(1), 3-49.

Geßler, A., Keitel, C., Kreuzwieser, J., Matyssek, R., Seiler, W. \& Rennenberg, H. (2007), 'Potential risks for European beech (Fagus sylvatica L.) in a changing climate', Trees - Structure and Function 21, 1-11. 
Gessler, A., Schneider, S., von Sengbusch, D., Weber, P., Hanemann, U., Huber, C., Rothe, A., Kreuzer, K. \& Rennenberg, H. (1998), 'Field and laboratory experiments on net uptake of nitrate and ammonium by the roots of spruce (Picea abies) and beech (Fagus sylvatica) trees', New Phytologist 138(2), 275-285.

Govindarajulu, M., Pfeffer, P.E., Jin, H., Abubaker, J., Douds, D.D., Allen, J.W., Bücking, H., Lammers, P.J. \& Shachar-Hill, Y. (2005), 'Nitrogen transfer in the arbuscular mycorrhizal symbiosis', Nature 435(9).

Güsewell, S. (2004), 'N:P ratios in terrestrial plants: variation and functional significance', New Phytologist 164(2), 243-260.

Harley, J. \& Smith, S. (1983), Mycorrhizal symbiosis, Academic Press, New York.

Harrison, M. J., Dewbre, G. R. \& Liu, J. (2002), 'A phosphate transporter from Medicago truncatula involved in the acquisition of phosphate released by arbuscular mycorrhizal fungi', The Plant Cell 14, 2413-2429.

Harrison, M. J. \& van Buuren, M. L. (1995), 'A phosphate transporter from the mycorrhizal fungus Glomus versiforme’, Nature 378, 626-629.

Hawkins, H.-J., Johansen, A. \& George, E. (2000), 'Uptake and transport of organic and inorganic nitrogen by arbuscular mycorrhizal fungi', Plant and Soil 226, 275-285.

Hiol, F. H., Dixon, R. K. \& Curl, E. A. (1994), 'The feeding preference of mycophagous Collembola varies with the ectomycorrhizal symbiont', Mycorrhiza 5(2), 99-103.

Hobbie, E. (2006), 'Carbon allocation to ectomycorrhizal fungi correllates with belowground allocation in culture soils', Ecology 87(3), 563-569.

Hodge, A. (2001), 'Arbuscular mycorrhizal fungi influence decomposition of, but not plant nutrient capture from, glycine patches in soil', New Phytologist 151(3), 725-734.

Hodge, A. \& Fitter, A. H. (2010), 'Substantial nitrogen acquisition by arbuscular mycorrhizal fungi from organic material has implications for $\mathrm{n}$ cycling', Proceedings of the National Academy of Sciences of the United States of America 107(31), 13754-13759.

Högberg, M. N., Briones, M. J. I., Keel, S. G., Metcalfe, D. B., Campbell, C., Midwood, A. J., Thornton, B., Hurry, V., Linder, S., Näsholm, T. \& Högberg, P. (2010), 'Quantification of effects of season and nitrogen supply on tree below-ground carbon transfer to ectomycorrhizal fungi and other soil organisms in a boreal pine forest.', New Phytologist 187(2), 485-493.

Jacob, A., Hertel, D. \& Leuschner, C. (2012), 'On the significance of belowground over yielding in temperate mixed forests: separating species identity and species diversity effects', Oikos. In press. Online access 11 September 2012. 
Jayachandran, K., Schwab, A. \& Hetricic, B. (1992), 'Mineralization of organic phosphorus by vesicular-arbuscular mycorrhizal fungi', Soil Biology and Biochemistry 24(9), 897903.

Jin, H., Pfeffer, P. E., Douds, D. D., Piotrowski, E., Lammers, P. J. \& Shachar-Hill, Y. (2005), 'The uptake, metabolism, transport and transfer of nitrogen in an arbuscular mycorrhizal symbiosis', New Phytologist 168(3), 687-696.

Kerr, G. \& Cahalan, C. (2004), 'A review of site factors affecting the early growth of ash (Fraxinus excelsior L.)', Forest Ecology and Management 188(1-3), 225-234.

Kiers, E. T., Duhamel, M., Beesetty, Y., Mensah, J. A., Franken, O., Verbruggen, E., Fellbaum, C. R., Kowalchuk, G. A., Hart, M. M., Bago, A., Palmer, T. M., West, S. A., Vandenkoornhuyse, P., Jansa, J. \& Bücking, H. (2011), 'Reciprocal rewards stabilize cooperation in the mycorrhizal symbiosis', Science 333(6044), 880-882.

Kopinga, J. \& van den Burg, J. (1995), 'Using soil and foliar analysis to diagnose the nutritional status of urban trees', Journal of Arboriculture 21(1), 17-24.

Lambers, H., Raven, J. A., Shaver, G. R. \& Smith, S. E. (2008), 'Plant nutrient-acquisition strategies change with soil age', Trends in Ecology and Evolution 23(2), 95-103.

Landeweert, R., Hoffland, E., Finlay, R. D., Kuyper, T. W. \& van Breemen, N. (2001), 'Linking plants to rocks: ectomycorrhizal fungi mobilize nutrients from minerals', Trends in Ecology and Evolution 16(5), 248-254.

Lang, C. \& Polle, A. (2011), 'Ectomycorrhizal fungal diversity, tree diversity and root nutrient relations in a mixed Central European forest', Tree Physiology 31(5), 531538.

Lang, C., Seven, J. \& Polle, A. (2011), 'Host preferences and differential contributions of deciduous tree species shape mycorrhizal species richness in a mixed Central European forest', Mycorrhiza 21(4), 297-308.

Leigh, J., Hodge, A. \& Fitter, A. H. (2009), 'Arbuscular mycorrhizal fungi can transfer substantial amounts of nitrogen to their host plant from organic material', New Phytologist 181(1), 199-207.

Leuschner, C., Hertel, D., Coners, H. \& Büttner, V. (2001), 'Root competition between beech and oak: a hypothesis', Oecologia 126, 276-284.

LePage, B., Currah, R., Stockey, R. \& Rothwell, G. (1997), 'Fossil ectomycorrhizae from the middle eocene', American Journal of Botany 84(3), 410-412.

Lilleskov, E. A. \& Bruns, T. D. (2005), 'Spore dispersal of a resupinate ectomycorrhizal fungus, Tomentella sublilacina, via soil food webs', Mycologia 97(4), 762-769. 
Marmeisse, R., Guidot, A., Gay, G., Lambilliotte, R., Sentenac, H., Combier, J.-P., Melayah, D., Fraissinet-Tachet, L. \& Debaud, J. (2004), 'Hebeloma cylindrosporum - a model species to study ectomycorrhizal symbiosis from gene to ecosystem', New Phytologist 163, 481-498.

Martin, F., Aerts, A., Ahrén, D., Brun, A., Danchin, E. G. J., Duchaussoy, F., Gibon, J., Kohler, A., Lindquist, E., Pereda, V., Salamov, A., Shapiro, H. J., Wuyts, J., Blaudez, D., Buée, M., Brokstein, P., Canbäck, B., Cohen, D., Courty, P. E., Coutinho, P. M., Delaruelle, C., Detter, J. C., Deveau, A., DiFazio, S., Duplessis, S., Fraissinet-Tachet, L., Lucic, E., Frey-Klett, P., Fourrey, C., Feussner, I., Gay, G., Grimwood, J., Hoegger, P. J., Jain, P., Kilaru, S., Labbé, J., Lin, Y. C., Legué, V., Tacon, F. L., Marmeisse, R., Melayah, D., Montanini, B., Muratet, M., Nehls, U., Niculita-Hirzel, H., Oudot-Le Secq, M. P., Peter, M., Quesneville, H., Rajashekar, B., Reich, M., Rouhier, N., Schmutz, J., Yin, T., Chalot, M., Henrissat, B., Kües, U., Lucas, S., de Peer, Y. V., Podila, G. K., Polle, A., Pukkila, P. J., Richardson, P. M., Rouzé, P., Sanders, I. R., Stajich, J. E., Tunlid, A., Tuskan, G. \& Grigoriev, I. V. (2008), 'The genome of Laccaria bicolor provides insights into mycorrhizal symbiosis', Nature 452(7183), 88-92.

McGuire, K. L. (2007), 'Common ectomycorrhizal networks may maintain monodominance in a tropical rain forest', Ecology 88(3), 567-574.

Mellert, K. \& Göttlein, A. (2012), 'Comparison of new foliar nutrient thresholds derived from van den Burg's literature compilation with established Central European references', European Journal of Forest Research 13105, 1461-1472.

Müller, T., Avolio, M., Olivi, M., Benjdia, M., Rikirsch, E., Kasaras, A., Fitz, M., Chalot, M. \& Wipf, D. (2007), 'Nitrogen transport in the ectomycorrhiza association: the Hebeloma cylindrosporum-Pinus pinaster model', Phytochemistry 68(1), 41- 51.

Morel, M., Buée, M., Chalot, M. \& Brun, A. (2006), 'NADP-dependent glutamate dehydrogenase: a dispensable function in ectomycorrhizal fungi', New Phytologist 169(1), 179-189.

Mougel, C., Offre, P., Ranjard, L., Corberand, T., Gamalero, E., Robin, C. \& Lemanceau, P. (2006), 'Dynamic of the genetic structure of bacterial and fungal communities at different developmental stages of Medicago truncatula Gaertn. cv. jemalong line J5', New Phytologist 170(1), 165-175.

Nehls, U., Grunze, N., Willmann, M., Reich, M. \& Küster, H. (2007), 'Sugar for my honey: carbohydrate partitioning in ectomycorrhizal symbiosis', Phytochemistry 68(1), 8291.

Näsholm, T., Kielland, K. \& Ganeteg, U. (2009), 'Uptake of organic nitrogen by plants', New Phytologist 182(1), 31-48. 
Nygren, C. M. R., Eberhardt, U., Karlsson, M., Parrent, J. L., Lindahl, B. D. \& Taylor, A. F. S. (2008), 'Growth on nitrate and occurrence of nitrate reductase-encoding genes in a phylogenetically diverse range of ectomycorrhizal fungi', New Phytologist 180(4), 875-889.

Nygren, C. M. R. \& Rosling, A. (2009), 'Localisation of phosphomonoesterase activity in ectomycorrhizal fungi grown on different phosphorus sources', Mycorrhiza 19(3), 197-204.

Pérez-Tienda, J., Valderas, A., Camañes, G., García-Agustín, P. \& Ferrol, N. (2012), 'Kinetics of $\mathrm{NH}_{4}{ }^{+}$uptake by the arbuscular mycorrhizal fungus Rhizophagus irregularis', Mycorrhiza 22, 485-491.

Petriţan, A., von Lüpke, B. \& Petriţan, I. (2009), 'Influence of light availability on growth, leaf morphology and plant architecture of beech (Fagus sylvatica), maple (Acer pseudoplatanus) and ash (Fraxinus excelsior) saplings', European Journal of Forest Research 128, 61-74.

Plassard, C. \& Dell, B. (2010), 'Phosphorus nutrition of mycorrhizal trees', Tree Physiology 30(9), 1129-1139.

Pollierer, M. M., Langel, R., Körner, C., Maraun, M. \& Scheu, S. (2007), 'The underestimated importance of belowground carbon input for forest soil animal food webs', Ecology Letters 10(8), 729-736.

Read, D. J. \& Perez-Moreno, J. (2003), 'Mycorrhizas and nutrient cycling in ecosystems - a journey towards relevance?', New Phytologist 157(3), 475-492.

Rennenberg, H., Kreuzer, K., Papen, H. \& Weber, P. (1998), 'Consequences of high loads of nitrogen for spruce (Picea abies) and beech (Fagus sylvatica) forests', New Phytologist 139(1), 71-86.

Rewald, B. \& Leuschner, C. (2009), 'Belowground competition in a broad-leaved temperate mixed forest: pattern analysis and experiments in a four-species stand', European Journal of Forest Research 128, 387-398.

Richardson, A. E., Barea, J.-M., McNeill, A. M. \& Prigent-Combaret, C. (2009), 'Acquisition of phosphorus and nitrogen in the rhizosphere and plant growth promotion by microorganisms', Plant and Soil 321(1-2), 305-339.

Rust, S. \& Savill, P. (2000), 'The root systems of Fraxinus excelsior and Fagus sylvatica and their competitive relationships', Forestry 73(5), 499-508.

Schachtman, D. P. Reid, R.J. \& Ayling, S. M. (1998), 'Phosphorus uptake by plants: from soil to cell', Plant Physiology 116(2), 447-453.

Scheu, S. \& Simmerling, F. (2004), 'Growth and reproduction of fungal feeding Collembola as affected by fungal species, melanin and mixed diets', Oecologia 139(3), 347-353. 
Scheublin, T. R., van Logtestijn, R. S. P. \& van der Heijden, M. G. A. (2007), 'Presence and identity of arbuscular mycorrhizal fungi influence competitive interactions between plant species', Journal of Ecology 95(4), 631-638.

Schüßler, A. (2009), 'Struktur, Funktion und Ökologie der arbuskulären Mykorrhiza.' In: Rundgespräche der Kommission für Ökologie, Vol. 37 "Ökologische Rolle von Pilzen", Bresinsky, A. \& Ziegler A. (Eds). Verlag Dr. Friedrich Pfeil, München; 97108.

Schulz, H., Härtling, S. \& Stange, C. F. (2011), 'Species-specific differences in nitrogen uptake and utilization by six European tree species', Journal of Plant Nutrition and Soil Science 174(1), 28-37.

Simon, J., Dannenmann, M., Gasche, R., Holst, J., Mayer, H., Papen, H. \& Rennenberg, H. (2011), 'Competition for nitrogen between adult European beech and its offspring is reduced by avoidance strategy', Forest Ecology and Management 262(2), 105-114. Environmental Stress and Forest Ecosystems: Case studies from Estonia.

Smith, S. E., Dickson, S. \& Smith, F. A. (2001), 'Nutrient transfer in arbuscular mycorrhizas: how are fungal and plant processes integrated?', Australian Journal of Plant Physiology 28, 685-696.

Smith, S. E. \& Read, D. J. (2008), Mycorrhizal Symbiosis, 3nd Edition, Academic Press, London.

Stadler, J., Gebauer, G. \& Schulze, E.-D. (1993), 'The influence of ammonium on nitrate uptake and assimilation in 2-year-old Ash and Oak trees - a tracer-study with ${ }^{15} \mathrm{~N}$, Isotopenpraxis Isotopes in Environmental and Health Studies 29(1-2), 85-92.

Talkner, U., Jansen, M. \& Beese, F. O. (2009), 'Soil phosphorus status and turnover in Central-European beech forest ecosystems with differing tree species diversity', European Journal of Soil Science 60(3), 338-346.

Tatry, M.-V., Kassis, E. E., Lambilliotte, R., Corratgé, C., van Aarle, I., Amenc, L. K., Alary, R., Zimmermann, S., Sentenac, H. \& Plassard, C. (2009), 'Two differentially regulated phosphate transporters from the symbiotic fungus Hebeloma cylindrosporum and phosphorus acquisition by ectomycorrhizal Pinus pinaster', The Plant Journal 57(6), 1092-1102.

Taylor, A. F. S. \& Alexander, I. (2005), 'The ectomycorrhizal symbiosis: life in the real world', Mycologist 19(3), 102 - 112.

Taylor, L. L., Leake, J. R., Quirk, J., Hardy, K., Banwart, S. A. \& Beerling, D. J. (2009), 'Biological weathering and the long-term carbon cycle: integrating mycorrhizal evolution and function into the current paradigm', Geobiology 7(2), 171-191. 
Teste, F. P. \& Simard, S. W. (2008), 'Mycorrhizal networks and distance from mature trees alter patterns of competition and facilitation in dry Douglas-fir forests', Oecologia 158(2), 193-203.

Tilman, D. (1982), Resource Competition and Community Structure, Princeton University Press, Princeton, New Yersey.

Trappe, J. (1987), 'Phylogenetic and ecologic aspects of mycotrophy in the angiosperms from an evolutionary standpoint', In: Safir, GR (Eds) Ecophysiology of VA Mycorrhizal Plants, RCR Press, Boca Raton, Florida; 2-25.

van Aarle, I. M. \& Olsson, P. A. (2003), 'Fungal lipid accumulation and development of mycelial structures by two arbuscular mycorrhizal fungi', Applied and Environmental Microbiology 69(11), 6762-6767.

van der Heijden, M. G. A., Wiemken, A. \& Sanders, I. R. (2003), 'Different arbuscular mycorrhizal fungi alter coexistence and resource distribution between co-occurring plant', New Phytologist 157(3), 569-578.

van der Heijden, M. G. A., Bardgett, R. D. \& van Straalen, N. M. (2008), 'The unseen majority: soil microbes as drivers of plant diversity and productivity in terrestrial ecosystems', Ecology Letters 11(3), 296-310.

van der Heijden, M. G. A. \& Horton, T. R. (2009), 'Socialism in soil? The importance of mycorrhizal fungal networks for facilitation in natural ecosystems', Journal of Ecology 97(6), 1139-1150.

van der Heijden, M. G. A., Wiemken, T. B. A. \& Sanders, I. R. (1998), 'Different arbuscular mycorrhizal fungal species are potential determinants of plant community structure', Ecology 79(6), 2082-2091.

Vance, C. P. (2001), 'Symbiotic nitrogen fixation and phosphorus acquisition. Plant nutrition in a world of declining renewable resources', Plant Physiology 127(2), 390-397.

Wagg, C., Jansa, J., Stadler, M., Schmidt, B. \& van der Heijden, M. G. A. (2011), 'Mycorrhizal fungal identity and diversity relaxes plant-plant competition', Ecology 92(6), 1303-1313.

White, P. J. \& Hammond, J. P. (2008), Plant Ecophysiology, Vol.7, Springer, Berlin. 


\title{
Chapter 2
}

\author{
THE COMPETITION FOR \\ PHOSPHORUS BETWEEN BEECH \\ (FAGUS SYLVATICA) AND ASH \\ (FRAXINUS EXCELSIOR)
}




\subsection{Introduction}

The role of mycorrhiza for plant productivity and competition for nutrients attracts growing interest in ecological research. It is well known that mycorrhiza has a great impact on plant nutrient acquisition, especially in nutrient limited conditions (Scheublin et al. 2007, Smith \& Read 2008, Smith et al. 2003, Treseder 2004). Phosphorus (P) is essential for plants as a structural element with numerous functions in metabolism and growth. It has been suggested that plant competition for phosphorus depends mainly on its availability in soil (Allcock 2002). Due to its high reactivity with soil particles (absorption), positive ions (precipitation) and $\mathrm{P}$ uptake by microorganisms (immobilisation), the main part of $\mathrm{P}$ in soil is not available for plant uptake (White \& Hammond 2008). This makes it beside nitrogen $(\mathrm{N})$ to the most forest growth limiting nutrient worldwide (Abel et al. 2002, Rausch \& Bucher 2002, Schachtman et al. 1998). In terrestrial ecosystems P limitation is widespread (Wardle et al. 2004). In European forest ecosystems, especially the chemical composition of the foliage of beech (Fagus sylvatica) indicates P deficit (de Vries et al. 2003).

In plants forming mycorrhizal symbiosis, the competition for nutrients is mainly carried out by mycorrhizal fungi (Facelli \& Facelli 2002, Hodge 2004, Richardson et al. 2009, van der Heijden \& Horton 2009). Tree species in temperate forests form different mycorrhizal life forms, whereof ectomycorrhiza (EM) and arbuscular mycorrhiza (AM) are the most abundant. Both AM and EM types have been reported to take up phosphorus (reviewed in Plassard and Dell 2010). Still, EM has been usually associated with uptake of other nutrients, especially N (Corrêa \& Martins- Loução 2001). Because most tree species associate only with one type of mycorrhiza, distinct mycorrhizal communities occur in mixed forests. These in turn might differ in their access to P. Since the preservation and extension of mixed forest stands has become an important aspect of sustainable forest management worldwide, knowledge about competition of tree species with differing mycorrhizal types for $\mathrm{P}$ is of great relevance.

Linkage of trees to mycorrhizal network has a strong impact on plant growth as well as on inter- and intraspecific competition (Selosse et al. 2006, Teste \& Simard 2008). For example, Teste and Simard (2008) showed that an access to mycorrhizal network increased the seedling survival in the competition experiment with Douglas-fir seedlings. In a tropical rain forest, a network of EM enhanced the survival of seedlings leading to spatial monodominance of EM forming tree species in an area usually dominated by tree species with arbuscular mycorrhiza (McGuire 2007). Hereby, the advantage of a mycorrhizal network is based on interplant 
facilitation of nutrient and water exchange (Peuke \& Rennenberg 2004, Selosse et al. 2006, Teste \& Simard 2008).

The functional differences between plant species with different mycorrhizal strategies are of great importance for the formation of plant community structures (Cornelissen et al. 2001, van der Heijden \& Horton 2009). In comparison of plants with different mycorrhizal types, plants with AM were associated with comparatively high growth ratio, high foliar $\mathrm{N}$ and $\mathrm{P}$ content and fast litter decomposition, whereas EM type trees are associated with intermediate growth ratio, lower foliar $\mathrm{N}$ and $\mathrm{P}$ contents and intermediate to slow litter decomposability (Cornelissen et al. 2001).

Despite the significance of phosphorus in tree nutrition, little research has been conducted on mycorrhizal benefits on plant $\mathrm{P}$ acquisition, especially in $\mathrm{P}$ limited systems. Controlled studies of plant-mycorrhiza interactions are often made with plants inoculated with one fungal species in an early colonization state and often hampered by low mycorrhizal colonisation. In field studies, a mixture of tree species and understory plants with diverse mycorrhizal associations hinder the study of species effects. Moreover, studies on the competition for $\mathrm{P}$ between tree species with different mycorrhizal types under controlled conditions are virtually inexistent.

In the present study, we aim to investigate the $\mathrm{P}$ competition between tree species with different mycorrhizal types in nutrient limited conditions. We performed a ${ }^{33} \mathrm{P}$ tracer experiment with tree saplings grown in monocultures and two-species mixtures to test the following hypotheses related to P uptake: (1) EM fungi differ in their P accumulation, (2) tree species with $\mathrm{AM}$ and $\mathrm{EM}$ have different patterns of $\mathrm{P}$ uptake with conspecific and heterospecific neighbour, and (3) tree species with AM association have a greater competitive effect on trees with EM association than vice versa;

For this purpose, we chose ash (Fraxinus excelsior) which form AM, and beech (Fagus sylvatica), which form EM, since they commonly coexist in temperate deciduous forests (Emborg 1998, Meinen et al. 2009). The plants were grown in an outdoor area and possessed natural mycorrhizal communities. Mycorrhizal colonization was confirmed before the beginning of the labelling experiment and quantified for both mycorrhizal types at the harvest. Furthermore, the EM species diversity was determined with morphological and molecular approaches. 


\subsection{Material and Methods}

\subsubsection{Plant material}

Three year old European beech (Be, Fagus sylvatica, germinated June 2007) and one year old ash (As, Fraxinus excelsior, germinated June 2009) seedlings (seeds from ForstsaatgutBeratungsstelle Nds. FoA Oerrel, Germany) with similar plant height were planted (01.06.2010) pair wise in three combinations: As-As, Be-Be, As-Be. Plants were grown in pots with a sand-peat mixture of 4.5 parts fine sand $(\varnothing 0.7-1.3 \varnothing), 4.5$ parts coarse sand $(\varnothing 0.4$ $0.8 \mathrm{~mm}$ ) and 1 part peat in a shaded and wind protected outdoor area. Stem diameter at ground level and plant shoot height were recorded twice before (05.08.2010 and 08.11.2010) and during the harvest $(26.08 .2011,29.08 .2011,02.09 .2011)$.

In natural ecosystems plant nutrient pool is limited. In order to conduct nutrient limited conditions, plants in our experiment were grown in nutrient limited system. Plants were watered regularly with tap water $\left(\mathrm{pH} 7,7-8,4, \mathrm{NH}_{4}<0.1 \mathrm{mg} \mathrm{l}^{-1},{ }^{+} \mathrm{NO}_{3}, 6-10 \mathrm{mg} \mathrm{l}^{-1}, \mathrm{NO}_{2}<0,04\right.$ $\mathrm{mg} \mathrm{l}^{-1}, \mathrm{P}$ compounds $0-0,1 \mathrm{mg}^{-1}$ ) and fertilized for a short time from 01.10.2010 to 31.12.2010 every second day with $15 \mathrm{ml}$ modified Matzners nutrient solution (Brandes 1999) with pH 3.9, containing $0.4 \mathrm{mM} \mathrm{NH}_{4} \mathrm{Cl}, 0.05 \mathrm{mM} \mathrm{NaSO}_{4}, 0.1 \mathrm{mM} \mathrm{K}_{2} \mathrm{SO}_{4}, 0.06 \mathrm{mM} \mathrm{MgSO}_{4}$, $0.13 \mathrm{mM} \mathrm{CaSO}_{4}, 0.03 \mathrm{mM} \mathrm{KH}_{2} \mathrm{PO}_{4}$ and with $0.005 \mathrm{mM}$ of the following nutrients: $\mathrm{CuSO}_{4}$, Fe-EDTA, $\mathrm{H}_{3} \mathrm{BO}_{3}, \mathrm{MnSO}_{4}, \mathrm{NaMoO}_{4}$ and $\mathrm{ZnSO}_{4}$, respectively. In the following season (01.01.2011 -19.08.2011), the plants were exposed to rain water and if necessary irrigated with tap water to avoid drought stress. Five days before labelling (19.08.2011), the plants were moved into an experimental green house and supplied daily with $50 \mathrm{ml}$ demineralised water. The growth conditions in the growth cabinet were $20^{\circ} \mathrm{C}$, a $16 \mathrm{~h}$ photoperiod with 90 $110 \mathrm{mmol} \mathrm{m} \mathrm{m}^{-2} \mathrm{~s}^{-1}$ photosynthetically active radiation (PAR) at plant height and $60 \%$ air humidity.

\subsection{2 ${ }^{33} \mathrm{P}$ labelling and harvest}

Each pot was irrigated with $30 \mathrm{ml}$ of the modified Matzner nutrient solution containing additionally $3.7 \mathrm{MBq} \mathrm{H}_{3}{ }^{33} \mathrm{PO}_{4}$ and $4 \mathrm{mM} \mathrm{NH}_{4} \mathrm{NO}_{3}$ on day 0 to avoid acute $\mathrm{N}$ limitation. This 
corresponded to $0.93 \mathrm{mg}$ P including $6.27 \mathrm{ng}{ }^{33} \mathrm{P}$ and $3.78 \mathrm{mg} \mathrm{N}$ per pot. From now on plants were irrigated daily with $50 \mathrm{ml}$ demineralised water per pot until harvest.

The number of leaves, stem lengths, stem diameters and the biomass of leaves, stem, branches, fine roots and coarse roots were determined at the harvest. Plants were divided in three groups and harvested 1, 4 and 8 days after the labelling. The roots were briefly washed with tap water to remove sand and peat and separated in fine $(<2 \mathrm{~mm})$ and coarse root $(>2$ $\mathrm{mm}$ ) fractions. Aliquots of the fine roots were dried and the remaining fine roots were stored in moist tissue paper in plastic bags at $5^{\circ} \mathrm{C}$ for further analysis.

All plant fractions including mycorrhizal root tips, samples of vital non-mycorrhizal- and dry root tips as well as soil were dried for at least $7 \mathrm{~d}$ at $60^{\circ} \mathrm{C}$ and stored at room temperature. Dry plant fractions were homogenized with a blender (Waring Commercial Blendor, Dynamics Corporation of America, New Hartford, Connecticut, USA) and milled in a ball mill (Type MM2, Retsch, Haan, Germany).

\subsubsection{Autoradiography}

Autoradiography was used to qualitatively determinate the distribution of the phosphorus within ash and beech grown in monocultures and mixtures. For this purpose, one pot per treatment was used before the actual labelling experiment (05.-13.07.2011). The experimental setup was similar except following changes: 1) $1.9 \mathrm{MBq} \mathrm{H}_{3}{ }^{32} \mathrm{PO}_{4}$ used instead of $3.7 \mathrm{MBq}$ $\mathrm{H}_{3}{ }^{33} \mathrm{PO}_{4}$; 2) during the experiment, plants were irrigated daily with $40 \mathrm{ml}$ demineralised water; 3) plants were harvested and dried for at least $24 \mathrm{~h}$ at $60^{\circ} \mathrm{C}$. For autoradiography images, dried fine roots and leaves were placed on paperboards, covered with transparent film (Toppits, Melitta, Minden, Germany). Subsequently, the samples were exposed on imaging plates (BASIII, Fuji Photo Film (Europe) Co., Ltd., Düsseldorf, Germany) between 30 min and $1 \mathrm{~h}$ depending on the amount of the radioactive decay. The plates were read out by a phosphor imager (FLA-5100, Fuji Photo Film (Europe) Co., Ltd., Düsseldorf, Germany) using an image analysing software (AIDA Image Data Analyzer software, Version 4.10.; Raytest Isotopenmeßgeräte $\mathrm{GmbH}$, Straubenhardt, Germany).

\subsection{4 ${ }^{33}$ P Measurements}

Mycorrhizal root tips, fine roots and leaves $(1-5 \mathrm{~g})$ were weighted, ashed at $500^{\circ} \mathrm{C}$ for $1 \mathrm{~h}$ (Heraeus M Muffle Furnace, Heraeus Instruments, Hanau, Germany) and suspended in $10 \mathrm{ml}$ 
of scintillation cocktail (Lumasafe ${ }^{\mathrm{TM}}$ plus, Lumac LSC B.V., Groningen, Netherlands). Radioactivity was determined by liquid scintillation analyzer (Tri-Carb 2800TR Counter, Perkin Elmer Life Sciences, Rodgau-Jügesheim, Germany).

Soil ${ }^{33} \mathrm{P}$ activity was analysed with a non-destructive ${ }^{33} \mathrm{P}$ analysis method, requiring no ashing and scintillation cocktail. The calibration was carried out using equivalent non-labelled samples as internal standards. For the calculation of the efficiency, internal standards were prepared by addition of $66.77 \mathrm{kBq} \mathrm{H}{ }_{3}^{33} \mathrm{PO}_{4}$ in $20 \mathrm{~g}$ dry control soil, dried and weighed in scintillation vials of $22 \mathrm{ml}$ volume. Radioactivity was determined using WIZARD3 Automatic Gamma Counter (Perkin Elmer Life Sciences, Massachusetts, USA).

The ${ }^{33} \mathrm{P}$ activity in the plant tissues, mycorrhizal structures and soil was calculated with the equation $A[\mathrm{~Bq}]=\left(\left(\mathrm{cpm}_{\text {sample-cpm }}\right.\right.$ background $) /$ efficiency $\left.) / 60\right)$, in which $\mathrm{cpm}=$ counts per minute.

The activity was corrected referring to the day of the ${ }^{33} \mathrm{P}$ incubation with the equation,

$$
A_{(t)}=A_{(0)} * 0.5^{\frac{T_{1}-T_{0}}{33 \mathrm{P} T(1 / 2)}}
$$

whereby $\mathrm{T}_{0}=$ time of labelling $\mathrm{T}_{1}=$ time of measurement and ${ }^{33} \mathrm{P} \mathrm{T}_{(1 / 2)}={ }^{33} \mathrm{P}$ half life $(25.3 \mathrm{~d})$.

\subsubsection{Ectomycorrhizal analysis}

The roots were examined under a stereomicroscope (Leica M205 FA, Leica Microsystems, Wetzlar, Germany). Per sample, root tips were counted until 1000 vital root tips were recorded. The numbers of vital, dead, mycorrhizal and non-mycorrhizal root tips were recorded. Live and dead root tips were separated using morphological criteria such as colour, root elasticity and the degree of cohesion of root stele and periderm (Leuschner et al. 2001). The percentage of EM colonization was calculated with the following equation:

$\mathrm{EM}[\%]=(n \text { mycorrhizal root tips } / n \text { vital root tips })^{*} 100$ (Supplement table S1).

$$
\text { VI }[\%]=\frac{n \text { dead root tips }}{n \text { vital root tips }} * 100
$$


The EM were morphotyped by morphological characteristics according to a simplified system of Agerer (1987-2006) as described before (Druebert et al. 2009, Lang et al. 2011). All morphotypes were photographed with a digital camera (Leica DFC420 C, Leica Microsystems, Wetzlar, Germany) and the abundances were recorded. Aliquots of $10-20$ root tips per fungal species were stored at $-20{ }^{\circ} \mathrm{C}$ for molecular analysis and in $70 \% \mathrm{EtOH}$ at room temperature for anatomical analysis. Relative abundance $(\mathrm{P} i)$ was calculated with the equation $(\mathrm{P} i=\mathrm{n} i / \mathrm{N})$, whereby $\mathrm{n} i=$ number of species $i$ in a sample and $\mathrm{N}=$ number of all found mycorrhizal root tips in the sample.

\subsubsection{Arbuscular mycorrhizal analysis}

Ash fine roots were inspected under a stereomicroscope (Leica M205 FA, Leica Microsystems, Wetzlar, Germany) and separated according to their colour and consistence to vital and dry root tips. Aliquots were stored in $70 \% \mathrm{EtOH}$ at room temperature for the mycorrhizal analysis. For the determination of the arbuscular mycorrhiza (AM) colonization, the roots were stained with Lactophenol Blue (Phillips \& Hayman, 1970) and stored at room temperature in $50 \%$ glycerine until use. The roots were examined with a light microscope (Zeiss, Oberkochen, Germany) by 200 x magnification. AM colonization was recorded after the magnified intersection method of McGonigle et al (1990) on a 10 x 10 grid. Four roots per plant were analysed. The following mycorrhizal structures were recorded: vesicles, arbuscles and hyphae. The relative AM fungal colonization was calculated as follows:

$\mathrm{AM}[\%]=(n \text { intersections with mycorrhizal structures/ } n \text { intersections with root tissue })^{*} 100$ (Supplement table S1).

\subsubsection{Molecular identification of the EM species}

DNA was extracted from 10-20 mycorrhizal root tips per sample using the innuPREP Plant DNA Kit (Analytik Jena AG, AJ Innuscreen GmbH, Jena, Germany). The ITS region was amplified with the primer pair ITS1f 5'-CTTGGTCATTTAGAGGAAGTAA -3'and ITS4 5'TCCTCCGCTTATTGATATGC -3’ (White et al., 1990; Gardes \& Bruns, 1993). PCR products were cloned in the pGEM $^{\circledR}-\mathrm{T}$ Vector (Promega, Madison, WI, USA) and transformed into electrocompetent $E$. coli cells (E. coli TOP10, Invitrogen, Carlsbad, 
California, USA). Positive clones were sequenced with ABI Prism 3100 Genetic Analyzer (Applied Biosystems, Carlsbad, California, USA) and edited with Staden Package (4.10). The fungal species were identified by comparison of the sequences with the NCBI Genbank (www.ncbi.nlm.nih.gov) and with the UNITE databases (http://www.unite.ut.ee). If the blast score was higher than 700 bits and the homology more than $97 \%$, the species suggested in Genbank, preferably the UNITE result was quoted. If the score was higher than 600 , the homology $>95$ and $<87 \%$ and both databases suggested the same genus, the species was named as unknown species of the suggested genus (Supplement table S2).

\subsubsection{Fine root architecture}

Three randomly chosen fine root sections per plant were scanned on a flat-bed scanner. The pictures were analysed with WinRhizo 2005c software (Régent Instruments Inc., Québec, QC, Canada) with following settings: Number of classes: 11 , filter: 0.5 , sensitivity: more, 0.2 steps and dark root compatible threshold methods. Thereafter, the roots were weighed and dried at $70^{\circ} \mathrm{C}$ for 3 days. The dry weight was recorded. We calculated root length (RL), root surface area $(\mathrm{SA})$, root volume (RV), number of root tips, forks and crossings and average root diameter (AD) as well as specific root area (SRA) and specific root surface area (SSA) for the entire root sample and for eleven root classes from $0.00-0.20 \mathrm{~cm}$ up to $>2.00 \mathrm{~cm}$ root diameter (Supplement table S3, and S4)

Specific root length was calculated with the equation SRL $\left[\mathrm{cm} \mathrm{g}^{-1} \mathrm{dw}\right]=\left(\right.$ root length ${ }_{\text {sample }} /$ root dry mass sample), and specific surface area as SSA $\left[\mathrm{cm} \mathrm{g}^{-1}\right]=\left(\mathrm{SA}_{\text {sample }} /\right.$ root dry weight $\left.\mathrm{sample}_{\text {s }}\right)$. The number of root tips in the sample were calculated per mg dry weight, number of forks and crossings were calculated in relation to root length $\left(n \mathrm{~cm}^{-1}\right)$ (Supplement table S5).

\subsubsection{Elemental analysis}

$\mathrm{P}$ content of homogenised fine root and leaf samples were measured after extraction in $65 \%$ $\mathrm{HNO}_{3}$ for $12 \mathrm{~h}$ at $170^{\circ} \mathrm{C}$ according to Heinrichs et al. (1986) with an inductively coupled plasma mass spectrometer ICP-AES (Spectro Analytic Instruments, Kleve, Germany). For analysis of $\mathrm{N}$ and $\mathrm{C}$, homogenized leaf and fine root samples were used (Supplement table 
S6). EM root tips, fine root sections with AM, dead and vital non mycorrhizal fine root tips were directly weighed into tin capsules $(4 \times 6 \mathrm{~mm})$. Samples were analysed with an isotope ratio mass spectrometer Delta C (Finnigan MAT, Bremen, Germany).

\subsubsection{Data analysis}

Statistical analyses were performed with software R 2.10.0 (Team 2008). The homogeneity of variance and normal distribution of the data were tested with Levene's test and Shapiro-Wilk test of normality. If the preconditions of analysis of variance (ANOVA) were not met, data were log-transformed. When transformated data did not meet these requirementsKruskalWallist test was used to detect significant differences between the treatments As-As, Be-Be, As-Be. The pairwise comparisons were in this case calculated with Wilcoxon rank sum test.

Relations between plant nutrient element concentrations in plant tissues and plant biomass were calculated with Spearman's rank correlation test.

We used ANOVA to analyse the effects of intra- and interspecific competition for ${ }^{33} \mathrm{P}$ concentrations in different plant tissues (fine roots, coarse roots, stem and branches) of beech and ash. We used species, treatment (monoculture and two species mixture) and day of harvest $(1,4$ and 8$)$ as factors and ${ }^{33} \mathrm{P}$ concentrations in different plant tissues and plant ${ }^{33} \mathrm{P}$ content as response variables. To detect significant differences between the treatments, we pooled the data of all three harvests. The pairwise comparsions were calculated with Tukey's HSD test.

The relative annual height growth (RAG) was calculated with the equation: $\mathrm{RAG}[\%]=\left(\mathrm{h}_{1}-\right.$ $\left.\mathrm{h}_{0}\right) /\left(\mathrm{h}_{0}\right) * 100$, whereby $\mathrm{h}_{0}=$ shoot height in August 2010 and $\mathrm{h}_{1}=$ shoot height in August 2011 at the time of the harvest. The figures were generated with the software Origin 8.5G (Origin Lab Corp., Northampton, USA) and R 2.10.0 (Team 2008).

The ${ }^{33} \mathrm{P}$ uptake rates were calculated for three sampling intervals, from day of labelling to first harvest, from first to second harvest (d1-d4) and from second to third harvest with the equation

$v=\left\{\left[\left(P_{2}\right)-\left(P_{1}\right)\right] / t\right\} / \mathrm{m}$

whereby $P_{1}$ and $P_{2}$ represent the ${ }^{33} \mathrm{P}$ content of plants at the beginning and end of the sampling interval. $t$ is the time between the samplings and $m$ ist the mean dry mass of the plants per time intervall. Subsequently, an average of $v$ values of both sampling intervals was calculated. 
The relative competition intensity was calculated according to Cambbell and Grime (1992), with the equation:

$\left.R C I_{\mathrm{P}}=\left(\mathrm{a}_{\mathrm{mix}}-\mathrm{a}_{\mathrm{mono}}\right) / \mathrm{a}_{\mathrm{mono}}\right]^{*} 100$. Hereby $\mathrm{a}_{\text {mix }}$ and $\mathrm{a}_{\text {mono }}$ represent the plant ${ }^{33} \mathrm{P}$ content $[\mathrm{kBq}$ plant $\left.^{-1}\right]$ of ash and beech saplings grown in monocultures and in mixtures.

Similarly we calculated the relative annual growth intensity

$\mathrm{RCI}_{\text {growth. }}$ Hereby $\mathrm{a}_{\mathrm{mix}}$ and $\mathrm{a}_{\text {mono }}$ represent the relative annual height growth [\%] of ash and beech saplings grown in monocultures and in mixtures.

\subsection{Results}

\subsubsection{Mycorrhizal colonization in ash and beech}

The relative abundance of mycorrhizal structures in ash fine roots in monoculture was $76 \pm 3$ $\%$ and in two species mixture $75 \pm 4 \%(P=1.0)$. No significant differences occurred between tree species or treatments.

For EM mycorrhizal analysis, a total of 52336 vital beech root tips were observed. The percentage of vital ectomycorrhizal (EM) root tips of beech in monoculture was $69 \pm 4 \%$ and in two species mixture with ash $71 \pm 5 \%(P=0.285)$. We recorded 21 EM morphotypes, whereof 12 EM species were identified by ITS sequence data (Supplement table S1).

\subsubsection{Relative abundance of EM species}

Tomentella castanea colonized $62 \%$ of mycorrhizal beech root tips in monoculture and $70 \%$ in the two species mixture (Tab. 2.1). The second most abundant species was Sebacina sp., occurring on $20 \%$ of the mycorrhizal root tips in beech monoculture and $20 \%$ in two species mixture. Other EM species colonized in average $1 \%$ or less of the mycorrhizal beech root tips. No differences occurred between the relative abundances of one fungal species in different treatments. 
Table 2.1: Relative abundance (Pi) of ectomycorrhizal species of Fagus sylvatica grown in monoculture (mono) and two species mixture with Fraxinus excelsior (mix)

\begin{tabular}{lcc}
\hline Species & $\mathrm{P} i$ (mono) & $\mathrm{P} i(\mathrm{mix})$ \\
\hline Paxillus involutus & $6.1 \pm 2.4 \mathrm{a}$ & $1.4 \pm 0.3 \mathrm{a}$ \\
Rhizoscyphus sp. & $5.4 \pm 2.8 \mathrm{a}$ & $0.0 \pm 0.0 \mathrm{a}$ \\
Sebacina sp. & $19.8 \pm 5.3 \mathrm{~b}$ & $19.7 \pm 4.4 \mathrm{~b}$ \\
Tomentella castanea & $61.9 \pm 5.8 \mathrm{c}$ & $69.5 \pm 7.8 \mathrm{c}$ \\
Tomentella badia & $4.8 \pm 1.5 \mathrm{a}$ & $5.0 \pm 1.1 \mathrm{a}$ \\
Other EM species & $2.0 \pm 0.8 \mathrm{a}$ & $4.3 \pm 2.9 \mathrm{ab}$
\end{tabular}

Data indicates means $( \pm \mathrm{SE}) \cdot \mathrm{n}_{\text {mono }}=34, \mathrm{n}_{\text {mix }}=20$. Different letters in columns indicate significant differences between fungal species with $P \leq 0.05$. Statistics was performed with ANOVA and pair wise comparisons with Tukey's HSD test.

\subsection{3 ${ }^{33} \mathrm{P}$ in soil}

Soil ${ }^{33} \mathrm{P}$ was analysed after harvest. The mean values of beech and ash monocultures were $2541 \pm 496$ and $3043 \pm 547 \mathrm{kBq}^{-1}$, in mixture $2537 \pm 615 \mathrm{kBq}^{-1}$ pot $^{-1}$, respectively. No significant differences were found between labelled pots beech and ash monocultures $(P<$ $0.138)$, monocultures and mixture $\left(P_{\text {ash }}<0.101 ; P_{\text {beech }}=1.00\right)$ or between harvest days. The ${ }^{33} \mathrm{P}$ content in control pots were beech monoculture; $2 \pm 3 \mathrm{kBq}^{-1}$, ash monoculture; $3 \pm 7 \mathrm{kBq}$ pot $^{-1}$ and mixture $5 \pm 9 \mathrm{kBq}^{-1}$ pot $^{-1}$ respectively.

\subsection{4 ${ }^{33} \mathrm{P}$ accumulation in EM species}

One day after labelling, ${ }^{33} \mathrm{P}$ concentration of all EM species was higher than that of background radiation. The highest concentrations of ${ }^{33} \mathrm{P}$ were measured in EM root tips of beech and in EM rhizomorphs (Fig 2.1). Vital non-mycorrhizal root tips of beech had a significantly higher ${ }^{33} \mathrm{P}$ concentration than dry beech root tips $(P=0.014$, Fig. 2.1$)$. This result was consistent also in comparison of the treatments (Be-Be and $\mathrm{As}-\mathrm{Be})$. In contrast to this, vital and dry ash fine roots had similar ${ }^{33} \mathrm{P}$ concentrations $(P=0.999$, Fig. 2.1). 


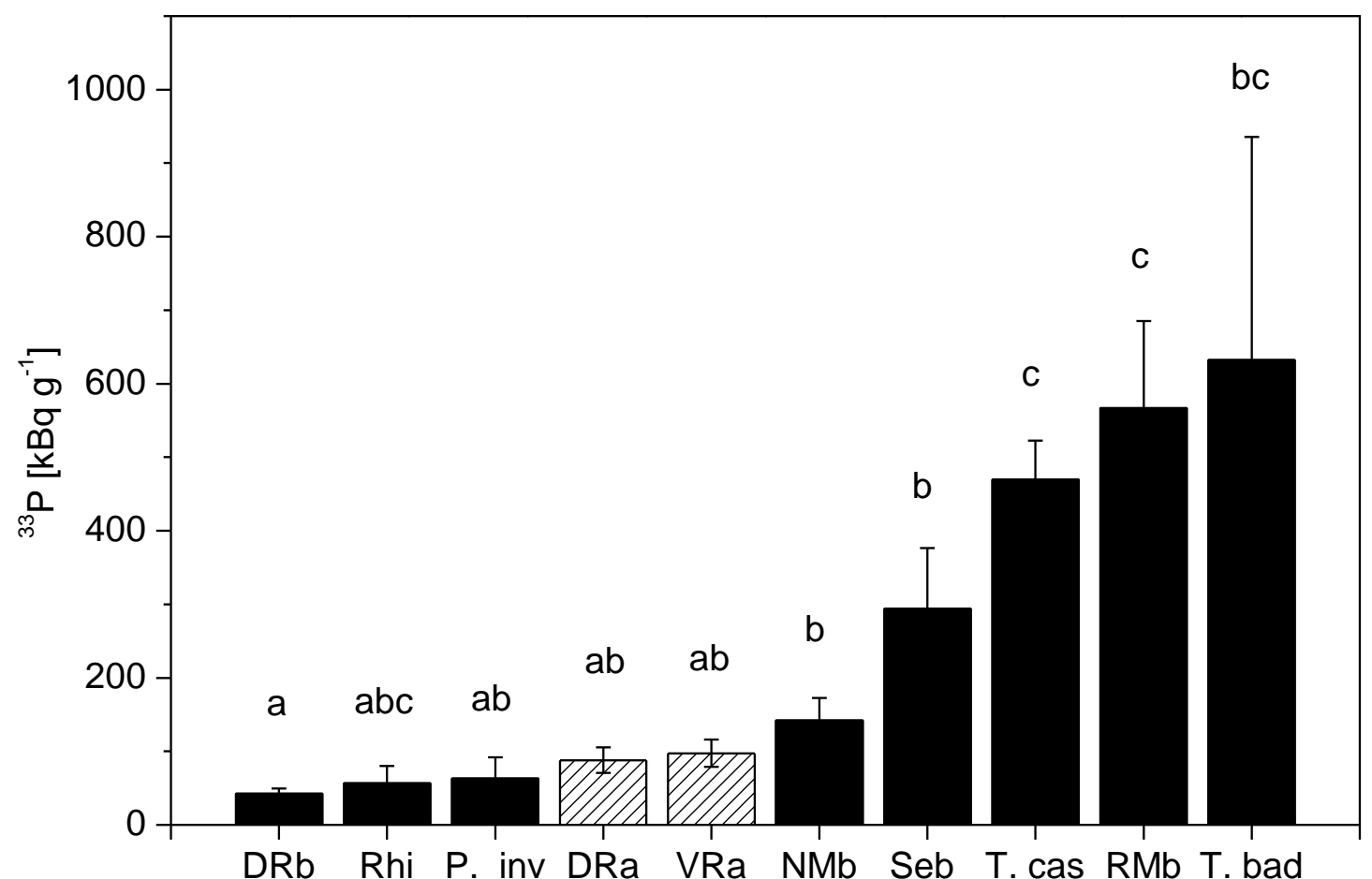

Figure 2.1:33P concentration $\left(\mathrm{kBq} \mathrm{g}^{-1}\right)$ in mycorrhizal root tips of Paxillus involutus ( $\mathrm{P}$. inv), Rhizoscyphus sp. (Rhi), Sebacina sp. (Seb), Tomentella badia (T. bad), Tomentella castanea (T. cas), Rhizomorphs (RM), non-mycorrhzal beech fine roots (NMb), vital ash root tips (VRa) as well as dry ash $(\mathrm{DRa})$ and beech $(\mathrm{DRb})$ fine roots labelled with ${ }^{3} \mathrm{P}$. Different letters indicate significant differences among plant fractions with $P \leq 0.05$. Statistics was performed with ANOVA and pair wise comparisons with Tukey's HSD test.

For the analysis of ${ }^{33} \mathrm{P}$ accumulation of different EM species, a total of 118 samples EM root tips of seven EM species were analyzed. Three of these species were sufficiently abundant during the time course of labelling and could therefore be used to measure ${ }^{33} \mathrm{P}$ concentrations in mycorrhizal root tips after one, four and eight days of labelling (Fig. 2.2).

After one day labelling, all analysed EM species had reached a ${ }^{33} \mathrm{P}$ concentration that did not increase significantly during the subsequent experiment. Only in Sebacina sp., ${ }^{33} \mathrm{P}$ concentration increased in trend. T. castanea was highly enriched with ${ }^{33} \mathrm{P}$ already 1 day after labelling and remained high until the end of measurement on day 8. 


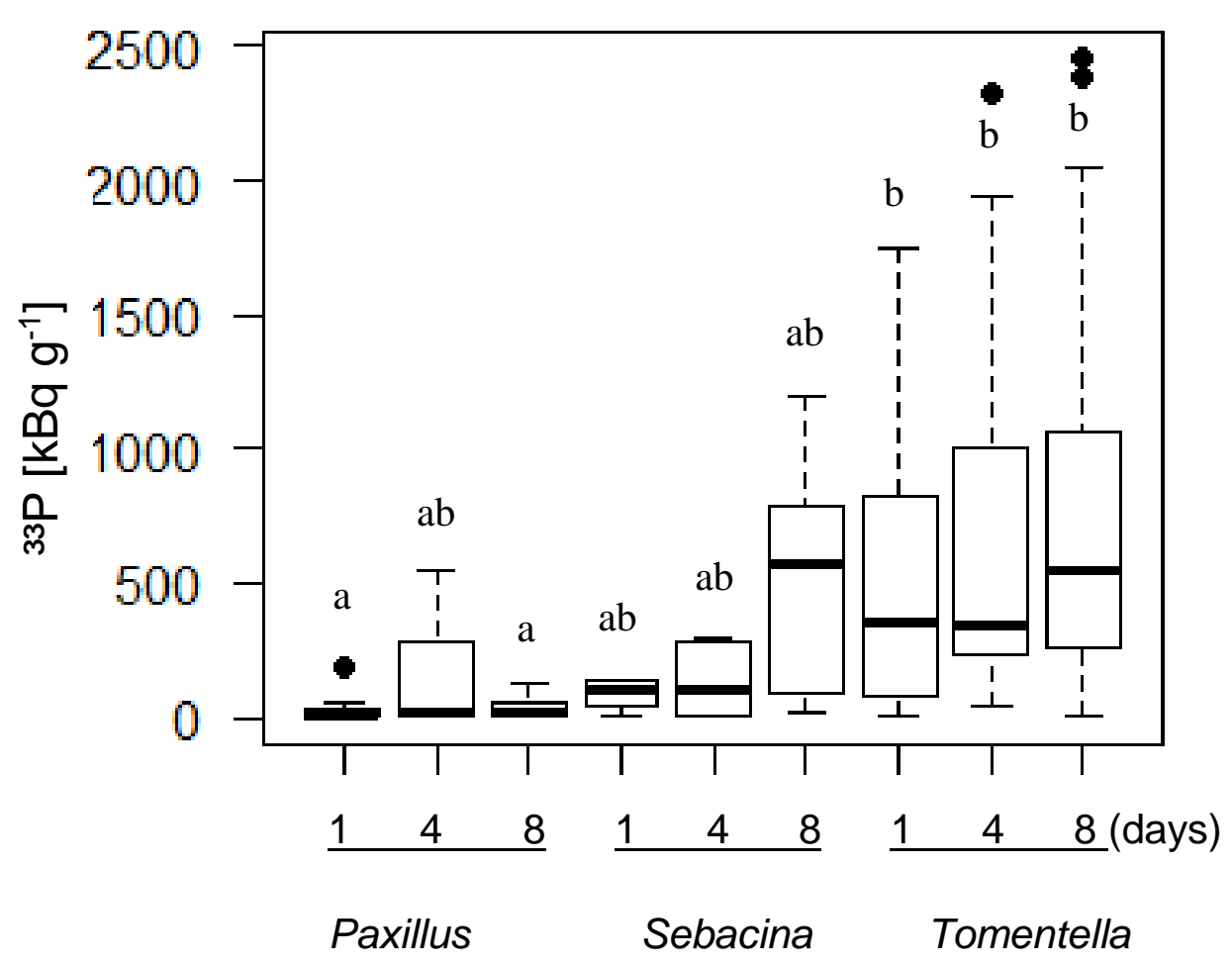

Figure 2.2:33 $\mathrm{P}$ concentration $\left(\mathrm{kBq} \mathrm{g}^{-1}\right)$ in mycorrhizal root tips of Paxillus involutus (Paxillus), Sebacina sp. (Sebacina) and Tomentella castanea (Tomentella) after 1, 4 and 8 days of incubation with ${ }^{33} \mathrm{P}$. Different letters indicate significant differences among plant fractions with $P<0.05$. Outliers were excluded with Bonferroni test. Statistics: Wilcoxon rank sum test following Kruskal-Wallis test.

In contrast to these two highly $\mathrm{P}$ accumulative EM species, the overall ${ }^{33} \mathrm{P}$ concentration of Paxillus involutus remained low during the incubation period. Other observed EM species had rather low ${ }^{33} \mathrm{P}$ concentrations with the exception of Tomentella badia, which displayed a ${ }^{33} \mathrm{P}$ concentration comparable to that of Sebacina sp. and T. castanea (Fig. 2.2). Due to the low abundances of these EM species, not all time points of labelling could be measured.

\subsubsection{Total phosphorus $(P)$ in fine roots and leaves}

Fine root and leaf $\mathrm{P}$ concentrations show that ash in mixture had lower $\mathrm{P}$ accumulation than in monoculture. As revealed in table 2.2, ash fine roots in monoculture had significantly higher 
P concentrations than beech fine roots in monoculture $(P=0.022)$ or beech in mixture $(P=$ 0.038). The $\mathrm{P}$ concentration in leaves of ash grown in monoculture was also significantly higher than in beech leaves. In contrast to this, $\mathrm{P}$ concentration decreased in fine roots and leaves of ash grown in mixture, resulting in $\mathrm{P}$ concentrations similar to those found in beech.

Table 2.2: Concentrations of phosphorous $(\mathrm{P})$ in leaves and fine roots of beech and ash in monocultures and mixtures

\begin{tabular}{llclll}
\hline Tree species & Treatment & $\mathbf{P}_{\text {leaves }}\left[\mathbf{m g ~ g}^{-1}\right]$ & & $\mathbf{P}_{\text {fine roots }}\left[\mathbf{m g ~ g}^{-1}\right]$ \\
\hline F. sylvatica & mono & 0.75 & $\pm 0.03 \mathrm{a}$ & 0.74 & $\pm 0.02 \mathrm{a}$ \\
F. excelsior & mono & 0.96 & $\pm 0.05 \mathrm{~b}$ & 0.85 & $\pm 0.05 \mathrm{~b}$ \\
F. sylvatica & mix & 0.75 & $\pm 0.05 \mathrm{a}$ & 0.75 & $\pm 0.03 \mathrm{a}$ \\
F. excelsior & mix & 0.85 & $\pm 0.06 \mathrm{ab}$ & 0.81 & $\pm 0.03 \mathrm{a}$
\end{tabular}

Data shows means $(n=16-26 \pm$ SE). Different letters in columns indicate significant differences among plant fractions with $P \leq 0.05$. Kruskal-Wallis test and pairwise comparisons using Wilcoxon rank sum test. Used $\mathrm{P}$ value adjustment method: Bonferroni.

\subsubsection{Phosphorus accumulation in fine roots and leaves}

To image the pattern of $\mathrm{P}$ distribution, autoradiography was used. Beech and ash saplings grown in monocultures and mixtures were labelled once and exposed to ${ }^{32} \mathrm{P}$ for eight days. Figure 2.3 illustrates that after 8 days incorporation, upper leaf ${ }^{32} \mathrm{P}$ concentrations of beech in mixture were higher than in beech grown in monoculture (Fig. 2.3 A, E). Ash leaves displayed an opposite pattern of P accumulation (Fig. 2.3 C, G). Here, the ash saplings grown in mixture with beech had lower P concentrations than those grown in monoculture after eight days labelling. ${ }^{32} \mathrm{P}$ was unequally distributed in fine roots of both species (Fig. 2.4). Beech (Fig. 2.4 A, B) and ash (Fig. 2.4 C, D) grown in monoculture showed no differences in ${ }^{32} \mathrm{P}$ accumulation. The autoradiograph of mixture showed, that ${ }^{32} \mathrm{P}$ was higher beech (Fig. $2.4 \mathrm{E}$, F) than in ash (Fig. $2.4 \mathrm{G}, \mathrm{H}$ ) fine roots. 

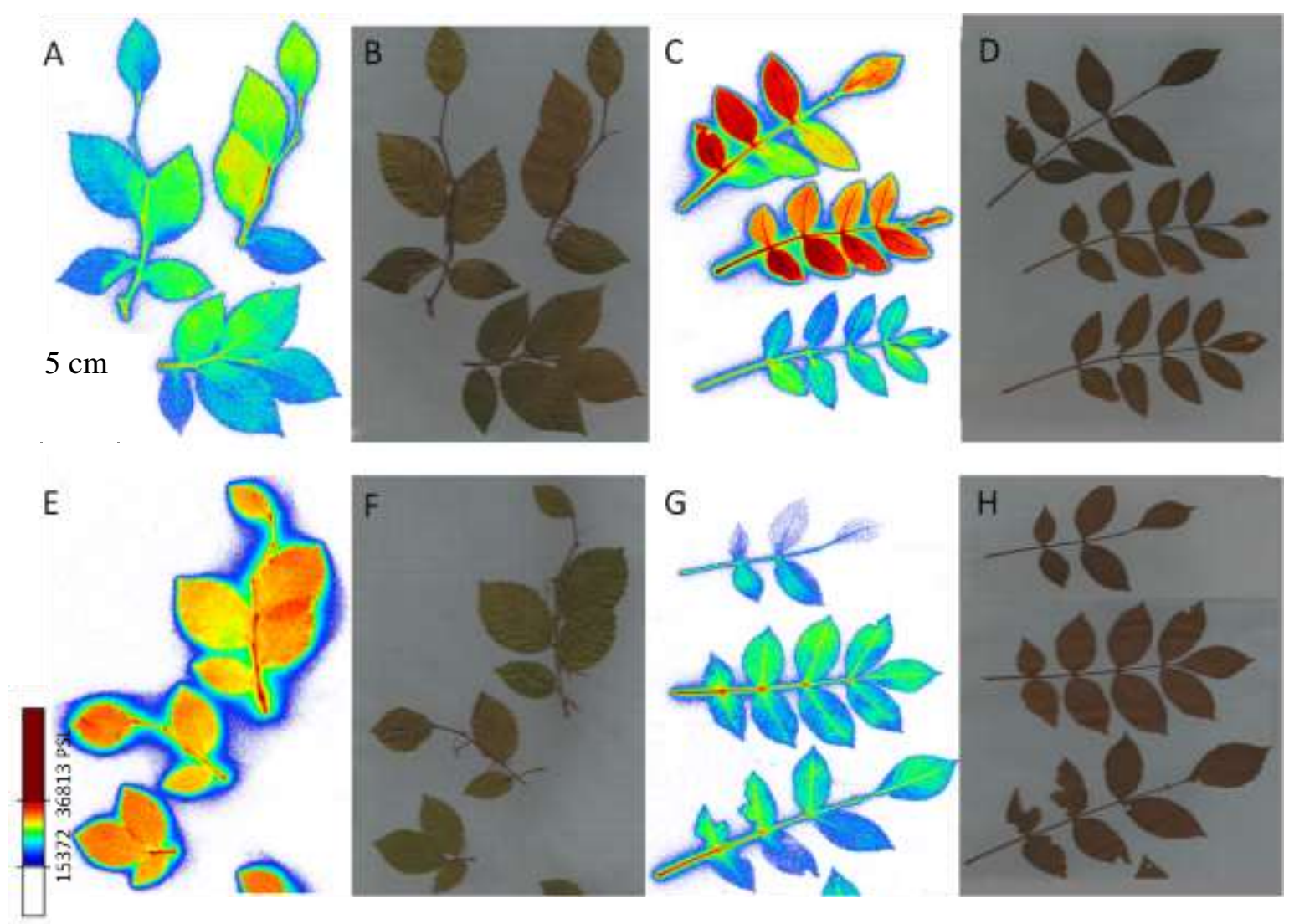

Figure 2.3: Representative autoradiographs and photographs of leaves of beech (A, B) and ash $(\mathrm{C}, \mathrm{D})$ grown in monocultures, as well as of beech $(\mathrm{E}, \mathrm{F})$ and ash $(\mathrm{G}, \mathrm{H})$ grown in two species mixtures after eight days labelling. The colours from blue to red indicate an increasing amount of incorporated ${ }^{32} \mathrm{P}$. The autoradiographs and photographs were taken in a preexperiment under similar experimental conditions. 

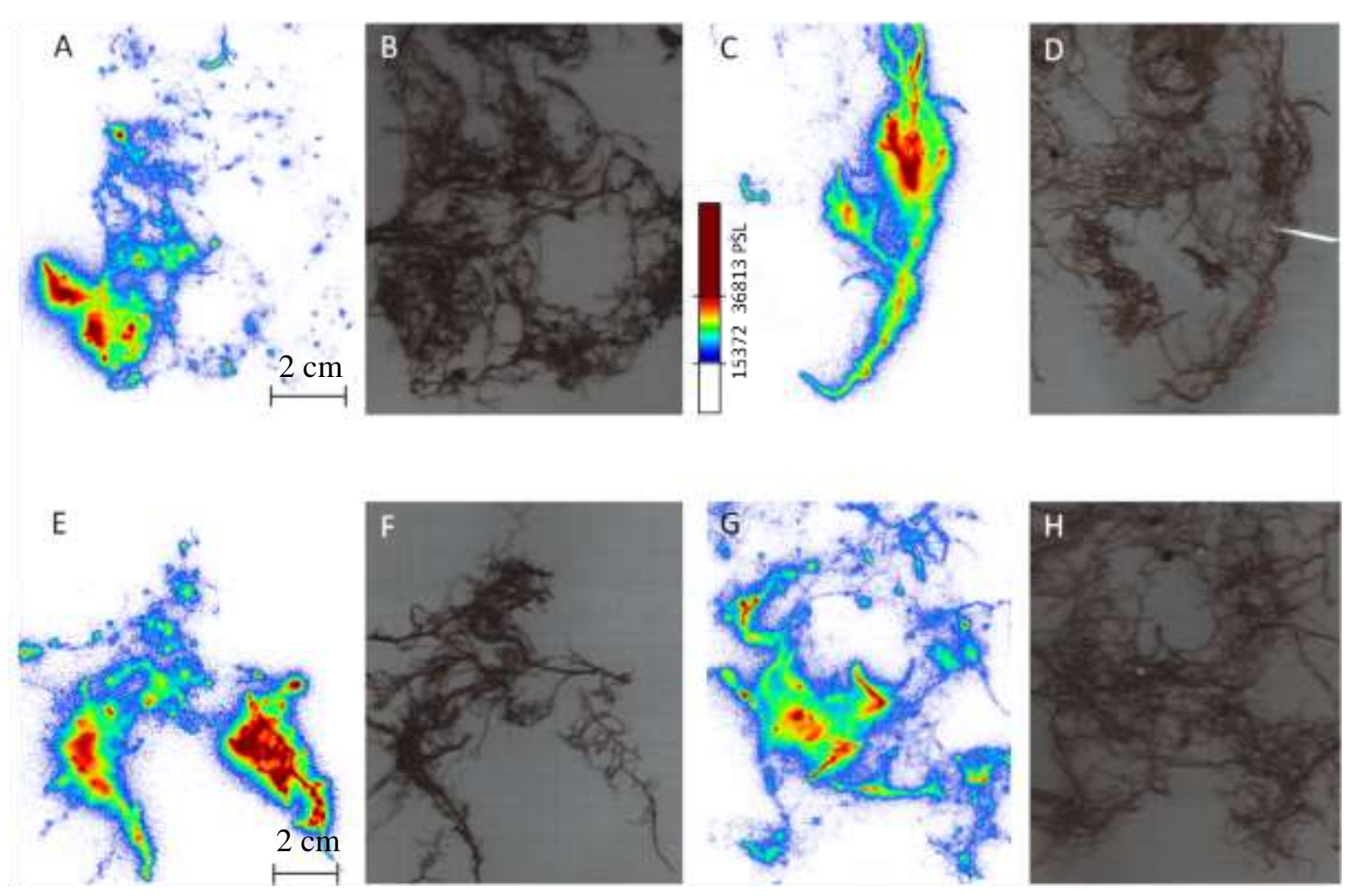

Figure 2.4: Representative autoradiograms and photographs of fine roots of beech (A, B) and ash $(C, D)$ grown in monocultures, as well as of beech (E, F) and ash $(\mathrm{G}, \mathrm{H})$ grown in two species mixtures after eight days labelling. The colours from blue to red indicate an increasing amount of incorporated ${ }^{32} \mathrm{P}$. The autoradiographs and photographs were taken in a preexperiment under similar experimental conditions.

Leaf and fine root ${ }^{33} \mathrm{P}$ concentrations as well as overall ${ }^{33} \mathrm{P}$ content of beech and ash increased during the experiment (Fig. 2.5). Whereas leaf ${ }^{33} \mathrm{P}$ concentration of ash and beech in monoculture were similar, in mixture the leaf ${ }^{33} \mathrm{P}$ concentrations of ash and beech differed significantly eight days after labelling $(P<0.001$, Fig $2.5 \mathrm{~A})$. The fine root ${ }^{33} \mathrm{P}$ concentrations of ash and beech differed also four days after labelling $(P<0.001)$. Similar differences were found overall ${ }^{33} \mathrm{P}$ contents of beech and ash in mixture (Fig. $2.5 \mathrm{~B}, \mathrm{C}$ ). Overall plant ${ }^{33 \mathrm{P}}$ contents showed a similar pattern; however the differences were significant only four days after labelling (Fig. 2.5 C). 

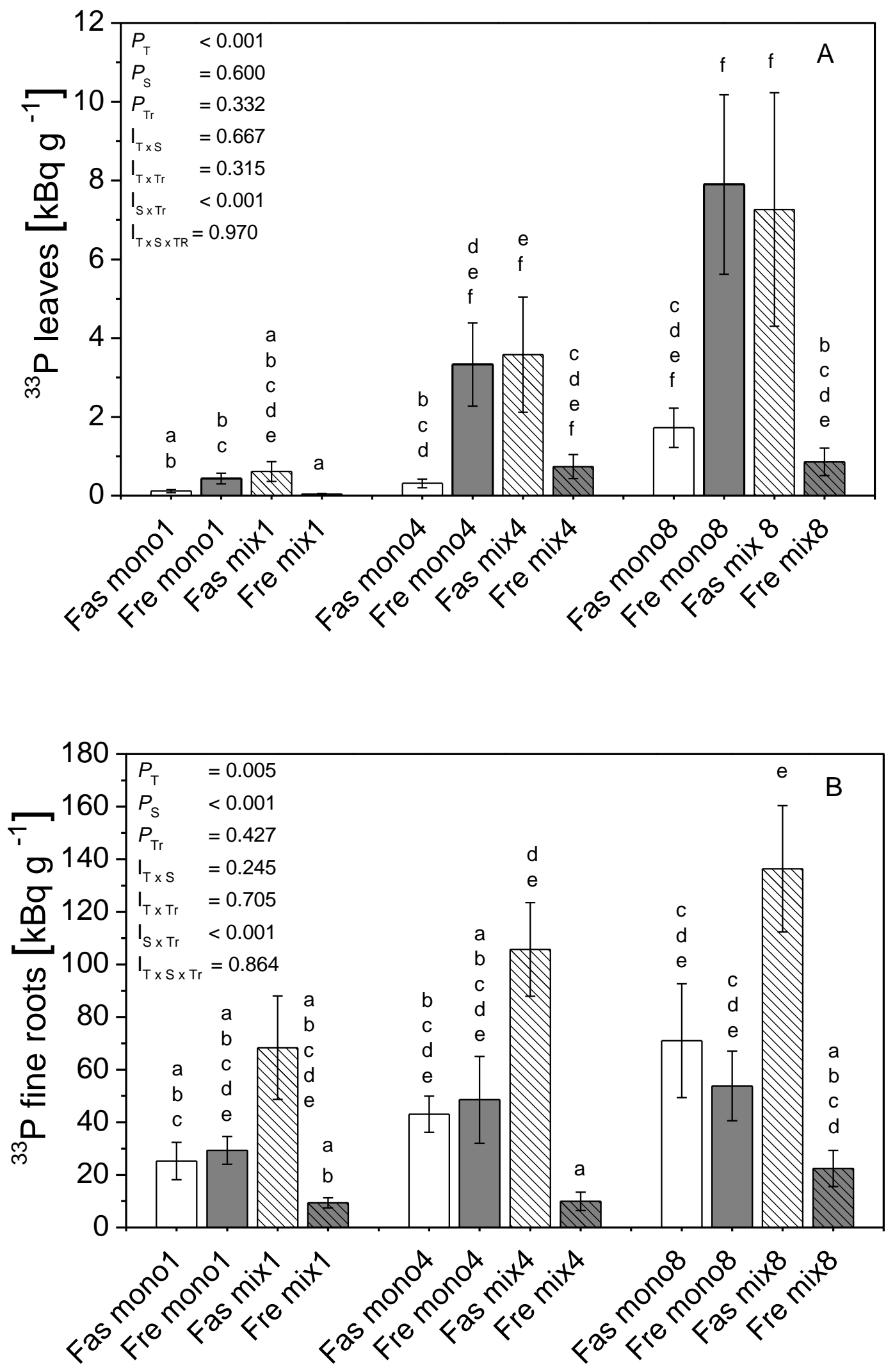


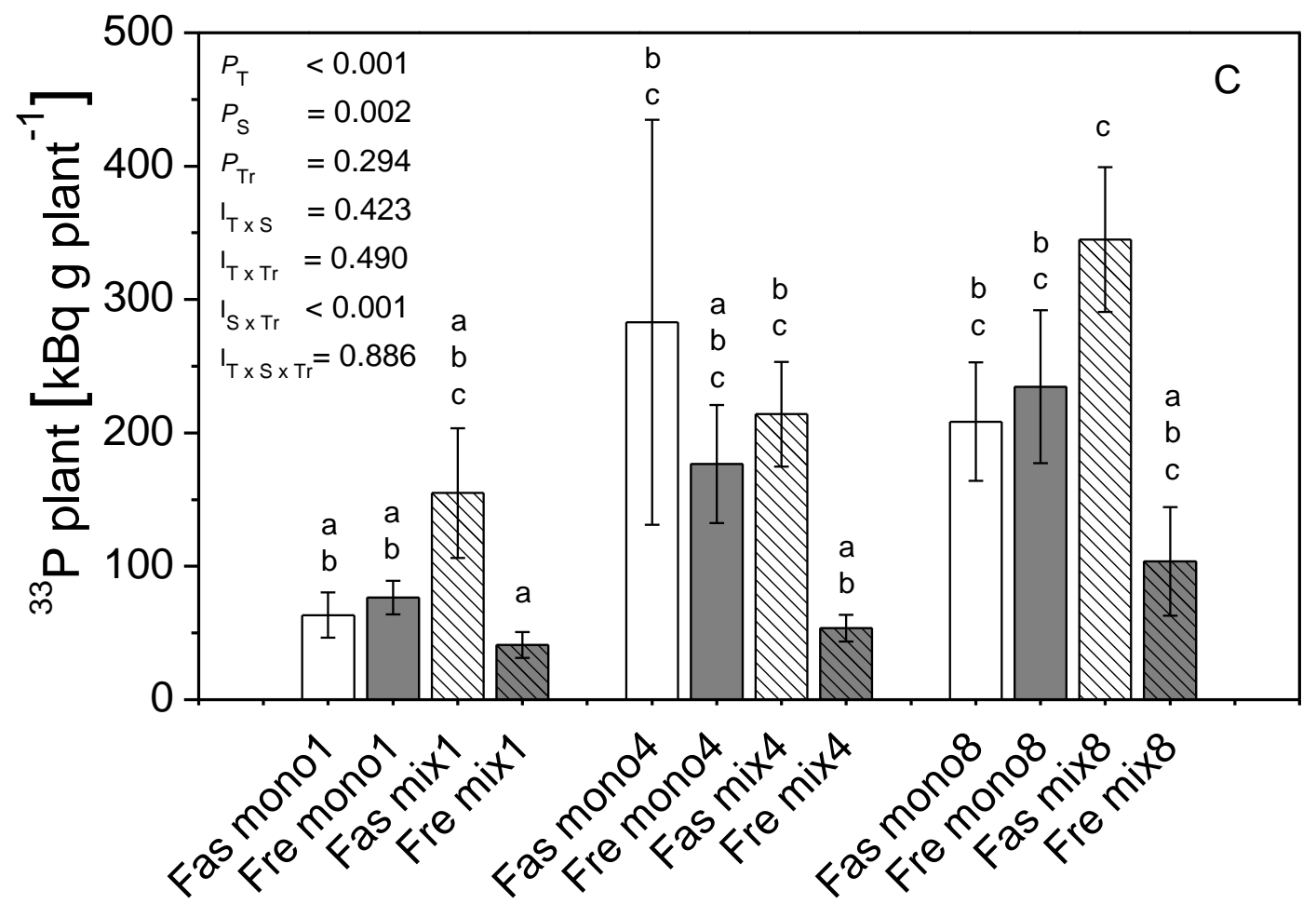

Figure 2.5: ${ }^{33} \mathrm{P}$ concentration $\left(\mathrm{kBq} \mathrm{g}^{-1}\right)$ of leaves $(\mathrm{A})$ and fine roots $(\mathrm{B})$ as well as overall ${ }^{33} \mathrm{P}$ content $(\mathrm{C})$ of ash and beech saplings grown in monocultures and two species mixtures after 1, 4 and 8 days labelling. Data indicates means $( \pm \mathrm{SE})$. Different letters indicate significant differences with $P \leq 0.05$. Ti $=$ time, $\mathrm{S}=$ species, $\mathrm{T}=$ treatment. Statistical analysis of ${ }^{33} \mathrm{P}$ concentration $\left[\mathrm{kBq} \mathrm{g}^{-1}\right]$ in plant tissues and overall ${ }^{33} \mathrm{P}$ content in plant tissues $\left[\mathrm{kBq} \mathrm{dw}^{-1}\right]$ was calculated with Tukey's HSD test following one-way ANOVA using log transformed data.

To investigate the effect of species identity of neighbouring tree on tree phosphorus accumulation, mean ${ }^{33} \mathrm{P}$ concentrations $\left[\mathrm{kBq} \mathrm{g}^{-1}\right],{ }^{33} \mathrm{P}$ contents in tissues and plants across all time points were calculated (Tab. 2.3). Fine root ${ }^{33} \mathrm{P}$ in ash decreased, whereas beech fine root ${ }^{33} \mathrm{P}$ increased in mixture. Similar pattern was observed in leaf ${ }^{33}$ accumulation. 
Table 2.3: ${ }^{33} \mathrm{P}$ concentrations $\left[\mathrm{kBqg}^{-1}\right]$ and ${ }^{33} \mathrm{P}$ content $[\mathrm{kBq}]$ of fine roots (FR), coarse roots (CR), leaves and stem, and overall ${ }^{33} \mathrm{P}$ content (Plant) of ash (Fraxinus excelsior) and beech (Fagus sylvatica) grown in monocultures and two species mixtures. Data indicates mean across all time points. The calculation of ${ }^{33} \mathrm{P}$ content is based on dry weights of tissues and total dry weights of plants

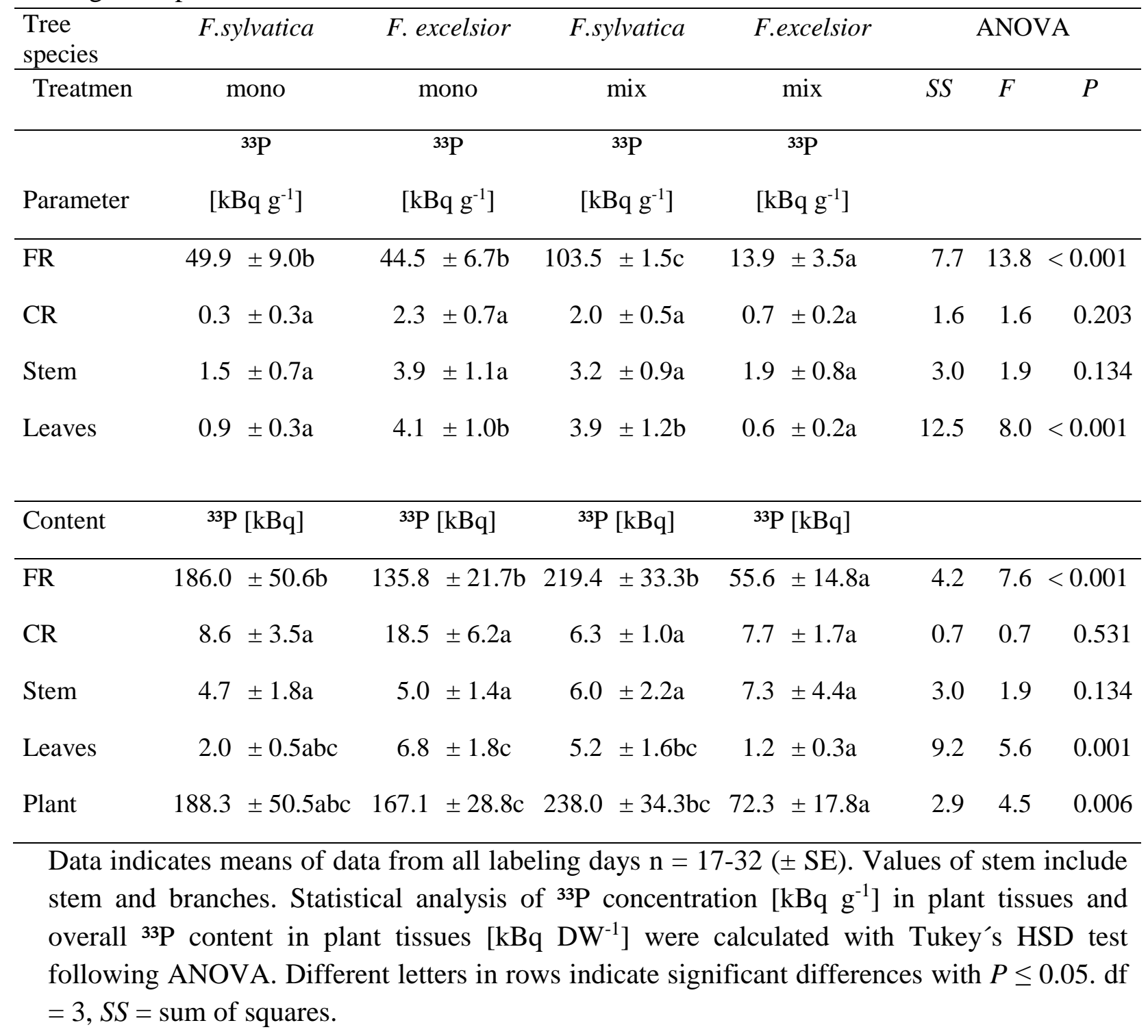


The concentration of recently accumulated ${ }^{33} \mathrm{P}$ was lower in fine roots of ash grown in two species mixture than in monoculture $(P=0.001)$ and higher in beech grown in two-species mixture than in beech grown in monoculture $(P=0.024)$. The ${ }^{33} \mathrm{P}$ concentrations in beech and ash leaves reflected the ${ }^{33} \mathrm{P}$ concentrations in fine roots. The highest plant ${ }^{33} \mathrm{P}$ contents were found in beech saplings grown in mixture, the lowest in ash in mixture (Tab. 2.3). The ${ }^{33} \mathrm{P}$ content of ash and beech saplings in mixture differed significantly $(P=0.003)$, whereas no differences between the species were found in monocultures $(P=0.945)$.

Table 2.4: Daily ${ }^{33} \mathrm{P}$ uptake rates of beech and ash grown in monoculture and mixture

\begin{tabular}{llccc}
\hline & & $\begin{array}{c}{ }^{33} \mathrm{P} \text { uptake rate } \\
{\left[\mathrm{kBq} \mathrm{g}^{-1}\right]}\end{array}$ & $\begin{array}{c}{ }^{33} \mathrm{P} \text { uptake rate } \\
{\left[\mathrm{kBq} \mathrm{g}^{-1}\right]}\end{array}$ & $\begin{array}{c}{ }^{33} \mathrm{P} \text { uptake rate } \\
{\left[\mathrm{kBq} \mathrm{g}^{-1}\right]}\end{array}$ \\
Species & Treatment & $\mathrm{d} 1-\mathrm{d} 0 / 1$ & $\mathrm{~d} 4-\mathrm{d} 1 / 3$ & $\mathrm{~d} 8-\mathrm{d} 4 / 4$ \\
\hline F.sylvatica & mono & $4.7 \pm 1.3 \mathrm{a}$ & $3.9 \pm 2.7 \mathrm{a}$ & $-1.9 \pm 0.3 \mathrm{~b}$ \\
F. excelsior & mono & $5.5 \pm 1.0 \mathrm{a}$ & $2.8 \pm 0.9 \mathrm{ab}$ & $0.8 \pm 0.8 \mathrm{ab}$ \\
F.sylvatica & mix & $7.5 \pm 3.8 \mathrm{a}$ & $1.4 \pm 1.0 \mathrm{ab}$ & $2.6 \pm 1.2 \mathrm{ab}$ \\
F. excelsior & mix & $1.8 \pm 0.5 \mathrm{ab}$ & $0.2 \pm 0.2 \mathrm{ab}$ & $0.5 \pm 0.5 \mathrm{ab}$ \\
\hline
\end{tabular}

\begin{tabular}{lcc}
\hline ANOVA & $F$ & $P$ \\
\hline Species & 0.280 & 0.598 \\
Treatment & 0.052 & 0.820 \\
Time interval & 23.917 & $<0.001 * * *$ \\
Species x Treatment & 5.225 & $0.025 *$ \\
Species x Time interval & 1.932 & 0.168 \\
Treatment x Time interval & 1.755 & 0.189 \\
Species x Treatment x Time interval & 0.142 & 0.708
\end{tabular}

Data shows means $(n=6-12, \pm S E)$. Significant differences between time intervals are marked with different Latin letters, those between mean values with different Greek letters. $P \leq 0.05$. Statistics was performed with ANOVA and pair wise comparisons with Tukey's HSD test. 


\subsection{7 ${ }^{33} \mathrm{P}$ uptake rate}

Ash in monoculture had the highest average daily uptake rates, followed by beech in mixture (Tab. 2.4). The ${ }^{33} \mathrm{P}$ uptake of beech in monoculture decreased from fourth to eigth harvest. In beech in monoculture, ash in monoculture and ash in mixture ${ }^{33} \mathrm{P}$ uptake did not change significantly during the experiment.

\subsubsection{Root morphology}

The root morphological characteristics might affect the $\mathrm{P}$ uptake of plants. We investigated root morphological parameters and root architecture to find out whether the interspecific competition altered the root demography. Specific root length and specific root surface area of beech were significantly higher than those of ash (Tab. 2.5). Ash had a higher average root diameter than beech. The fine root architecture of beech and ash did not differ between monoculture and mixture (Table S5).

Table 2.5: Specific root length (SRL), specific surface area (SSA), average fine root diameter (AD) and number of root tips of ash and beech fine roots grown in monocultures and two species mixtures

\begin{tabular}{|c|c|c|c|c|c|c|c|c|c|}
\hline $\begin{array}{c}\text { Tree } \\
\text { species }\end{array}$ & $\begin{array}{l}\text { Treat- } \\
\text { ment }\end{array}$ & & $\begin{array}{l}\mathrm{RL} \\
\left.\mathrm{g}^{-1}\right]\end{array}$ & & $\begin{array}{l}\mathrm{SA} \\
\left.\mathrm{a}^{2} \mathrm{~g}^{-1}\right]\end{array}$ & & $\begin{array}{l}\mathrm{AD} \\
\mathrm{mm}]\end{array}$ & & $\begin{array}{l}\text { ips } \\
\left.\mathrm{cm}^{-1}\right]\end{array}$ \\
\hline F. sylvatica & mono & 5282 & $\pm 290 \mathrm{a}$ & 460 & $\pm 24 \mathrm{a}$ & 2.8 & $\pm 0.1 \mathrm{a}$ & 3.1 & $\pm 0.1 \mathrm{a}$ \\
\hline F. excelsior & mono & 3252 & $\pm 166 b$ & 394 & $\pm 18 \mathrm{a}$ & 3.9 & $\pm 0.1 \mathrm{~b}$ & 1.0 & $\pm 0.1 \mathrm{~b}$ \\
\hline F. sylvatica & $\operatorname{mix}$ & 5989 & $\pm 467 \mathrm{a}$ & 495 & $\pm 46 a$ & 2.6 & $\pm 0.1 \mathrm{a}$ & 1.6 & $\pm 0.2 \mathrm{a}$ \\
\hline F. excelsior & $\operatorname{mix}$ & 3592 & $\pm 182 \mathrm{~b}$ & 430 & $\pm 18 \mathrm{a}$ & 3.8 & $\pm 0.1 \mathrm{~b}$ & 0.4 & $\pm 0.1 \mathrm{~b}$ \\
\hline
\end{tabular}

Data shows means $(n=20-36 \pm \mathrm{SE})$. $)$. Different letters in columns indicate significant differences among treatments with $P \leq 0.05$.Wilcoxon rank sum test following Kruskal-Wallis test.

Irrespective to the species identity of neighbouring tree, beech fine roots had a higher number of root tips, root forks and crossings, and ash a higher average fine root diameter. These results indicate that the differences in root morphology and architecture were species related and not influenced by the root competition. 


\subsubsection{Competition intensity}

The RCI of ash was significantly smaller than zero (Tab. 2.6). In contrast to ash, RCI of beech for P did not differ significantly from zero.

Table 2.6: Relative competition intensity (RCI) for phosphorus in ash (Fraxinus excelsior) and beech (Fagus sylvatica). Data indicates means values of one, four and eight days after labelling and mean across all time points $(1-8)$. The $P$ values demonstrate significant differences to 0 , whereby facilitation: $\mathrm{RCI}>0$ and competition $\mathrm{RCI}<0$ with $\mathrm{P} \leq 0.05$

\begin{tabular}{|c|c|c|c|c|}
\hline Species & day & RCI & $P$ & \\
\hline \multirow[t]{3}{*}{ F. sylvatica } & 1 & $145 \pm 84$ & 0.147 & \\
\hline & 4 & $-24 \pm 15$ & 0.171 & \\
\hline & 8 & $65 \pm 29$ & 0.070 & \\
\hline \multirow[t]{3}{*}{ F. excelsior } & 1 & $-46 \pm 16$ & 0.040 & $*$ \\
\hline & 4 & $-70 \pm 6$ & $<0.001$ & $* * *$ \\
\hline & 8 & $-56 \pm 19$ & 0.032 & $*$ \\
\hline F. sylvatica & $1-8$ & $62 \pm 33$ & 0.077 & \\
\hline F. excelsior & $1-8$ & $-58 \pm 8$ & $<0.001$ & $* * *$ \\
\hline
\end{tabular}

Data indicates means $( \pm$ SE).Statistic was calculated with t-test.

This result indicates a strong competition for $\mathrm{P}$ in mixture with beech compared to ash in monoculture. The results suggest that growth in species mixture with ash did not affect the $\mathrm{P}$ accumulation of beech, whereas ash had a competitive disadvantage.

\subsubsection{The effect of interpecific and intraspecific competition on plant growth}

Interspecific competition might differetially affect the plant growth than intraspecific competition. The relative growth during one growth period was faster in ash than in beech (Fig. 2.6). The growth of beech in mixture remained similar with beech in monoculture $(P=$ 0.083), whereas the growth of ash decreased $55 \pm 3 \%$ in mixture $(P=0.008)$. Generally, biomass was differently distributed in ash and beech (Supplement table S7), in which beech had higher aboveground biomass and ash higher root biomass. Fine root biomass however differed only between beech and ash in mixture $(P=0.035$, Supplement table S7). 


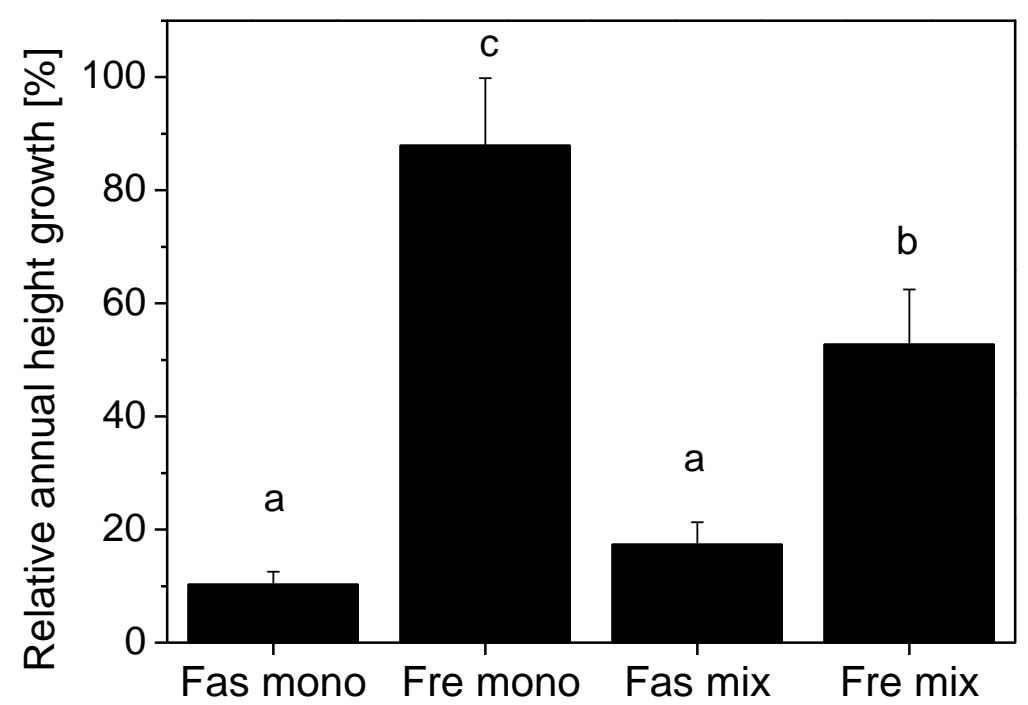

Figure 2.6: Relative annual height growth (\%) of ash and beech grown in monocultures (mono) and in two species mixture (mix). Statistical analysis was performed with Wilcoxon rank sum test following Kruskal-Wallis test with $P \leq 0.05$.

\subsubsection{The effect of competition for phosphorus on plant growth}

In order to investigate the relationship between plant growth and relative ${ }^{33} \mathrm{P}$ competition intensity we calculated the relative annual growth intensity ( $\left.\mathrm{RCI}_{\text {growth }}\right)$ of beech and ash and compared the values with the relative ${ }^{33} \mathrm{P}$ competition intensity $\left(\mathrm{RCI}_{\mathrm{P}}\right)$. High competition intensity of beech was related with high growth intensity (Fig. 2.7). The low competition intensity of ash linked to a low annual growth intensity. These results indicate that the $\mathrm{P}$ competition affected ash growth, whereas the growth intensity of beech linked with the high competition intensity for $\mathrm{P}$.

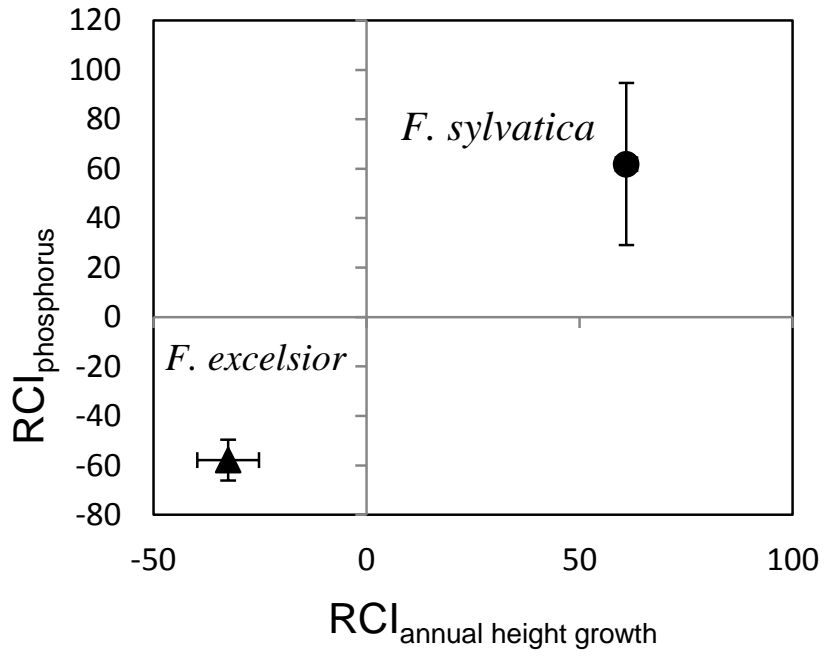

Figure 2.7: The relationship between relative annual $\mathrm{P}$ competition intensity and relative annual growth of beech and ash in nutrient limited conditions 


\subsection{Discussion}

\subsubsection{Plant phosphorus uptake in nutrient limited conditions}

The objective of our study was the comparison of phosphorus uptake of two co-existing tree species with different mycorrhizal associations in nutrient limited system.

The importance of mycorrhizal association in plant phosphorus acquisition is particularly important in ecosystems with strong P limitation (Bücking \& Heyser 2000, Bougher et al. 1990, Burgess et al. 1993). Bougher et al. (1990) showed that ectomycorrhizal infection with one of four different EM fungi (Descolea maculata; two isolates, Pisolithus tinctorius, and Laccaria laccata) improved plant P concentration and growth. Our experiment demonstrated, that beech colonising EM species accumulate $\mathrm{P}$ differently. The benefit of mycorrhizal association has been schon to decrease with the increasing level of available soil $\mathrm{P}$ until a point where the growth of non-mycorrhizal plants is not limited (Bougher et al. 1990). In an experiment from Burgess et al (1993), the effectiveness of 16 EM species in improving plant growth on high $\left(12 \mathrm{mg} \mathrm{kg}^{-1}\right)$ and low $\left(4 \mathrm{mg} \mathrm{kg}^{-1}\right) \mathrm{P}$ levels was examined. At low soil $\mathrm{P}$ concentrations EM association of Eucalyptus globulus and Eucalyptus diversicolor seedlings biomass exceeded up to 13 times that of non-mycorrhizal plants (Burgess et al. 1993). We therefore presume, that the EM species in our experiment accumulated $\mathrm{P}$ more effieciently than they accumulate on high P levels. Also Bücking and Heyser (2000) demonstrated that P transfer from EM to Pinus sylvestris seedlings inoculated with Suillus bovinus increased in P limited conditions, whereas high external $\mathrm{P}$ concentration resulted in higher $\mathrm{P}$ content in nonmycorrhizal roots than in EM colonized roots.

\subsubsection{Species specific differences in phosphorus uptake of EM}

Our results are in accordance to our first hypothesis that EM species differ in their ability to take up phosphorus. The most abundant EM fungus reached high ${ }^{33} \mathrm{P}$ concentrations within one labelling day, whereas other EM species did not accumulate P during the labelling. In Tomentella castanea, the ${ }^{33} \mathrm{P}$ concentrations were already high after one day labelling. In Sebacina sp., the concentration increased constitutively during labelling period. These results indicate a rapid uptake of external $\mathrm{P}$ within $24 \mathrm{~h}$ to an EM species specific level. This is in accordance with Jones et al (1991), who showed that plant P inflow rates of Eucalyptus 
coccifera were 3.8 times higher with EM Thelephora terrestris or L. bicolor than that of nonmycorrhizal plants and 1.4 times higher than that of AM inoculated plants (Jones et al. 1998).

The P concentration of Paxillus involutus remained low during the experiment. This result indicates that $P$. involutus did not take up $\mathrm{H}_{3}{ }^{33} \mathrm{PO}_{4}$ in a nutrient limited system. Since $P$. involutus has been demonstrated to take up $\mathrm{P}$, this result might reflect the functional diversity of EM with respect to $\mathrm{P}$ uptake. Paxillus involutus might rather take up other $\mathrm{P}$ sources or nutrients. Bücking and Heyser (2000) showed that P content in cells of P. involutus and its host Pinus sylvestris increased with $\left(\mathrm{NH}_{4}\right)_{2} \mathrm{HPO}_{4}$ supply compared to $\mathrm{KH}_{2} \mathrm{PO}_{4}$ and $\mathrm{NaH}_{2} \mathrm{PO}_{4}$, whereas $\mathrm{P}$ uptake of Suillus bovinus was not affected by $\mathrm{P}$ source. One explanation for this could be an adaptation to high soil nutrient conditions, as suggested by Lilleskov et al. (2002).

The different uptake of EM species might also result from different $\mathrm{P}_{\mathrm{i}}$ transporters found in EM species. In mycorrhizal fungi, high affinity $\mathrm{P}$ transporters of type $\mathrm{P}_{\mathrm{i}}: \mathrm{H}^{+}$have been reported (Martin et al. 2008, Tatry et al. 2009). The transcripts have mainly been detected in extraradical hyphae, and their expression level is enhanced by low $\mathrm{P}$ concentrations in soil (Plassard \& Dell 2010). Through increases in soil Pi availability, other transporters might be activated (Tatry et al. 2009). In our experiment, Tomentella badia had ${ }^{33} \mathrm{P}$ concentrations similar to $T$. castanea. This result indicates that closely relative species might have similar phosphorus acquisition strategies.

\subsubsection{Phosphorus accumulation via mycorrhiza}

In accordance to our second hypothesis, trees hosting AM and EM fungi had differed in their $\mathrm{P}$ uptake. Our result points towards comparisons of plants inoculated with AM or EM fungi performed with tree species (Eucalyptus, Salix) that form dual mycorrhizal associations (Jones et al. 1998, van der Heijden 2001). Jones et al (1998) showed that Eucalyptus seedlings inoculated with EM (L. bicolor or T. terrestris) had higher $\mathrm{P}$ content, shoot and root $\mathrm{P}$ concentrations and higher stem mass than seedlings inoculated with AM fungi. In another experiment with Salix repens inoculated with AM or EM, the plant performance and phosphorus contents were measured 12, 20 and 30 weeks after inoculation (van der Heijden 2001). Here, S. repens inoculated with AM had faster (< 12 weeks) response in P uptake as well as in shoot and root growth, but long-term (> 7 months) plants benefitted more from EM (van der Heijden 2001). Due to the few fungal species used as inocula, the results of these two 
studies might primarily reflect fungal taxon related differences in $\mathrm{P}$ accumulation. The measured uptake of $\mathrm{P}$ in $\mathrm{AM}$ fine root tips was remarkably low. The ${ }^{33} \mathrm{P}$ concentrations were comparable to those of non mycorrhizal beech fine roots. Similar fine root ${ }^{33} \mathrm{P}$ concentrations to those found in ash fine roots in our experiment have been reported in other plant species inoculated with the AM species Glomus intraradices (Nagy et al. 2005).

The differences of the mycorrhizal types in length and density of root external hyphae may result in lower concentrations of recent $\mathrm{P}$ in ash fine roots compared to beech. Jacobsen et al. (1992) demonstrated that the P uptake of two AM species with short external hyphae was over 25 times lower than that of AM species with long external hyphae. Compared to numerous EM species, the root external hyphae of $\mathrm{AM}$ are rather short (Glomus species $\leq 1 \mathrm{~cm}, G$. intraradices $\leq 3 \mathrm{~cm})$ (Agerer 1990, Jakobsen et al. 1992, Nagy et al. 2005) and do usually not form rhizomorphs (Dodd et al. 2000).

In a quantification of length of external hyphae, EM produced three to seven times more external hyphae than AM fungi. Hereby the hyphal length was highly correlated with plant $\mathrm{P}$ uptake and shoot weight (Jones et al. 1998). In our experiment, no quantification of external hyphae was conducted; however morphological analysis and sequence data confirmed that rhizomorphs of the most abundant EM species $T$. castanea were frequently found (Supplement table S2). The ${ }^{33} \mathrm{P}$ concentration in rhizomorphs had a signature similar to that of high accumulative EM root tips. Therefore, we suggest that external hyphae might have led to a competitive advantage for EM through larger space occupation and more efficient $\mathrm{P}$ uptake.

Early estimations by Harley and McCready (1952) showed that at low external P concentrations up to $90 \%$ of the P in EM structures might not be directly transported to beech (F. sylvatica). It has been suggested that high $\mathrm{P}$ concentration in EM structures results from permanent P uptake or serve as storage to overcome temporal P limitations (Smith \& Read 2008). Though, the high $\mathrm{P}$ accumulation in rhizomorphs and EM mantles might have limited the available $\mathrm{P}$ pool for ash.

Unexpectedly, P concentrations of vital mycorrhizal ash fine roots and dead ash roots were similar. That might be explained by the morphology of dead fine roots, but need further verification. 
The mean leaf $\mathrm{P}$ concentrations across all measured time points did not differ significantly between ash and beech. Based on the new critical nutrient foliar concentrations for beech (1.0 $\mathrm{mg} \mathrm{g}^{-1} \mathrm{P}$ ) suggested by Mellert and Göttlein (2012), beech leaf P (mono 0.8, mix $0.8 \mathrm{mg} \mathrm{g}^{-1}$ ) concentrations indicated a P deficiency. In this study, foliar nutrient thresholds of ash were not included, but according to van der Burg's (1985, 1990), original threshold values (1.3 mg $\mathrm{g}^{-1}$ ), also ash (mono: 1.0 , mix $0.9 \mathrm{mg} \mathrm{g}^{-1}$ ) was in $\mathrm{P}$ deficiency. This was expected because the saplings were not fertilized in the growth period before harvest.

\subsection{5 ${ }^{33} \mathrm{P}$ accumulation in leaves and fine roots}

The accumulation of recently acquired phosphorus examined with autoradiography and ${ }^{33} \mathrm{P}$ concentrations showed that similarly to the total $\mathrm{P}$ concentrations, in monoculture ash leaf $\mathrm{P}$ accumulation was higher and increased faster than in beech. In mixture the accumulation of recently acquired $\mathrm{P}$ in ash clearly decreased. Similarly, the fine root ${ }^{33} \mathrm{P}$ concentration of ash and beech resembled in monocultures, but fine roots of ash in mixture accumulated less P. These results are in accordance with our second hypothesis, that tree species with AM and EM have different patterns of $\mathrm{P}$ uptake with conspecific and heterospecific neighbor. Furthermore, our results indicate that ash might generally transport more or faster $\mathrm{P}$ to aboveground tissues than beech. There are some indications, that growth in neighbourhood of beech might affect nutrient uptake of ash. In an empirical study, nitrogen concentration of ash fine roots decreased in mixture with beech and lime, whereas $\mathrm{P}$ concentration of beech decreased in mixture with ash and lime (Lang \& Polle 2011). However, Lang and Polle (2011) studied a tree species mixture with more than two species, which might differentially influence the nutrient acquisition of each other.

The differences in recently acquired $\mathrm{P}$ in ash and beech in mixture were presumably not caused by $\mathrm{P}$ limitation during labelling. In plant pairs, a maximum of $1 \%$ of the ${ }^{33} \mathrm{P}$ added to the soil solution was detected (3.7 MBq ${ }^{33} \mathrm{P}$ added per pot, in average $166 \pm 60 \mathrm{kBq}$ recorded in plans). However soil samples might also contain mycorrhizal hyphae.

Furthermore, results of in vivo and in vitro analysis of ash and beech saplings suggest that ash out-competes beech in water acquisition (Rust \& Savill 2000). The water availability is connected with acquisition of $\mathrm{P}$. The poor mobility of $\mathrm{P}$ in soil is further reduced by drought, whereas the uptake of $\mathrm{N}$ is less affected (Peuke \& Rennenberg 2004). In our experiment, the plants were sufficiently watered and did not show any signs of water limitation. Beech 
saplings gained more and faster the accessible $\mathrm{P}$ via EM. In our experiment, according to morphological and sequence data, we found numerous highly ${ }^{33} \mathrm{P}$ enriched rhizomorphs of EM in the soil, but no comparable AM structures.

In our experiment, the $\mathrm{P}$ uptake of ash did not increase in relation to biomass. Whereas ash had a higher overall root mass and higher fine root mass in mixture, both total $\mathrm{P}$ concentration and concentrations of recently acquired ${ }^{33} \mathrm{P}$ in ash tissues decreased. The comparison of monocultures and two species mixtures of ash and beech in forest showed that fine root biomass of ash increased in mixture with beech, indicating a belowground competitive superior of ash (Jacob et al. 2012). Despite greater fine root mass of ash in mixture, its $P$ accumulation declined. Moreover, the annual growth rate of ash decreased by 55\% (Fig. 2.6). These results support the conclusion that despite the higher fine root biomass, growth in mixture affected the P uptake and growth of ash saplings. In contrast to ash, beech saplings had higher ${ }^{33} \mathrm{P}$ concentrations in mixture but similar overall ${ }^{33} \mathrm{P}$ contents in both treatments. In conclusion, the effect of interspecific competition on $\mathrm{P}$ uptake of beech was neutral.

\subsubsection{Interspecific competition for phosphorus}

To our knowledge, the competition for $\mathrm{P}$ between beech and ash has not been reported before. In contrast to our third hypothesis, AM association did not result in a competitive advantage for ash in $\mathrm{P}$ utilization. The relative competition index (RCI) indicates that growth in two species mixture with beech resulted in disadvantage for ash in $\mathrm{P}$ uptake. Thus, the hypothesis that ash with AM has a greater competitive effect on beech with EM was rejected. The relative competition index of ash indicated strong competition for phosphorus with beech. In contrast to ash, the growth of beech in species mixture did not result in facilitative or competitive interaction with ash. In our experimental design we intended to force competition between the two tree species. Therefore, the belowground rooting area was clearly restricted.

In experiments investigating the effects of $\mathrm{AM}$ colonisation on intraspecific competition indicate that AM species perform best in low densities (Facelli et al. 1999). Consequently, in lower densities less root competition might occur. 


\subsection{Conclusions}

In the present study, we investigated the $\mathrm{P}$ competition of two tree species with differing mycorrhizal strategies in a nutrient limited system.

EM fungi reveal functional diversity with respect to $\mathrm{P}$ uptake. The most abundant species T. castanea and Sebacina sp. emerged as high accumulative for $\mathrm{P}$ and reached within $24 \mathrm{~h}$ high ${ }^{33} \mathrm{P}$ concentrations. The uptake of recent phosphorus in $P$. involutus remained low during the experiment, which indicates uptake of other nutrients or other ecological functions. $\mathrm{P}$ concentrations of rhizomorphs were similar to high accumulative EM species. Unless P in EM structures might not be directly transported to beech, the accumulation might limit the available $\mathrm{P}$ pool for ash and serve as a reserve that supports the host plant to overcome temporal soil phosphate delimitations.

Conspecific and heterospecific neighbor differentially affected the $\mathrm{P}$ uptake of ash and beech. In monocultures, the higher $\mathrm{P}$ accumulation of ash leaves compared to beech can be considered as taxon related characteristics. The growth in species mixture decreased ash $\mathrm{P}$ accumulation significantly, whereas beech $\mathrm{P}$ acquisition was unaffected by the species identity of the neighbour. The changes in $\mathrm{P}$ accumulation of ash in mixture were however not related with modification of root architecture, which indicates that mycorrhiza and not root tissue took a decisive role in $\mathrm{P}$ uptake.

The relative competition index of ash indicated severe competition for phosphorus with beech whereas the effect of interspecific competition on $\mathrm{P}$ uptake of beech was neutral.

We conclude that in nutrient limited conditions, beech with EM can effectively compete for P with ash. 


\subsection{References}

Abel, S., Ticconi, C. A. \& Delatorre, C. A. (2002), 'Phosphate sensing in higher plants', Physiologia Plantarum 115(1), 1-8.

Agerer, R. (1987-2006), ‘Colour atlas of Ectomycorrhizae’, Einhorn, Schwäbisch Gmünd.

Agerer, R. (1990), 'Exploration types of ectomycorrhizae a proposal to classify ectomycorrhizal mycelial systems according to their patterns of differentiation and putative ecological importance', Mycorrhiza 11(2), 107-114.

Allcock, K. G. (2002), 'Effects of phosphorus on growth and competitive interactions of native and introduced species found in white box woodlands', Austral Ecology 27(6), 638-646.

Bücking, H. \& Heyser, W. (2000), 'Subcellular compartmentation of elements in nonmycorrhizal and mycorrhizal roots of Pinus sylvestris: an X-ray microanalytical study. I. the distribution of phosphate', New Phytologist 145(2), 311-320.

Bougher, N. L., Grove, T. S. \& Malajczuk, N. (1990), 'Growth and phosphorus acquisition of karri (Eucalyptus diversicolor f. Muell.) seedlings inoculated with ectomycorrhizal fungi in relation to phosphorus supply', New Phytologist 114(1), 77-85.

Brandes, B. (1999), 'Nährstofftransport durch das extramatrikale Myzel von Ektomykorrhizapilzen - Umfang und Einfluß auf die Ernährung der Fichte (Picea abies)', Culliverer Verlag, Göttingen, 1-88.

Burgess, T. I., Malajczuk, N. \& Grove, T. S. (1993), 'The ability of 16 ectomycorrhizal fungi to increase growth and phosphorus uptake of Eucalyptus globulus; F. Labill. and E. diversicolor; F. Muell.', Plant and Soil 153, 155-164.

Cornelissen, J., R. Aerts, B. C., Werger, M. \& van der Heijden, M. (2001), 'Carbon cycling traits of plant species are linked with mycorrhizal strategy', Oecologia 129(4), 611619.

Corrêa, A. \& Martins-Loução, M.-A. (2011), C:N interactions and the cost:benefit balance in ectomycorrhizae, In: Rai, M. \& Varma, A. (Eds), 'Diversity and Biotechnology of Ectomycorrhizae', Soil Biology 25, Springer, Berlin, 387-403.

de Vries, W., Vel, E., Reinds, G., Deelstra, H., Klap, J., Leeters, E., Hendriks, C., Kerkvoorden, M., Landmann, G., Herkendell, J., Haussmann, T. \& Erisman, J. (2003), 'Intensive monitoring of forest ecosystems in Europe: 1. Objectives, set-up and evaluation strategy', Forest Ecology and Management 174(1-3), 77-95.

Dodd, J., Boddington, C., Rodriguez, A., Gonzalez-Chavez, C. \& Mansur, I. (2000), 'Mycelium of arbuscular mycorrhizal fungi (AMF) from different genera: form, function and detection', Plant and Soil 226, 131-151. 
Druebert, C., Lang, C., Valtanen, K. \& Polle, A. (2009), 'Beech carbon productivity as driver of ectomycorrhizal abundance and diversity', Plant, Cell \& Environment 32(8), 9921003.

Emborg, J. (1998), 'Understorey light conditions and regeneration with respect to the structural dynamics of a near-natural temperate deciduous forest in Denmark', Forest Ecology and Management 106(2-3), 83-95.

Facelli, E. \& Facelli, J. M. (2002), 'Soil phosphorus heterogeneity and mycorrhizal symbiosis regulate plant intra-specific competition and size distribution', Oecologia 133(1), 5461.

Facelli, E., Facelli, J. M., Smith, S. E. \& McLaughlin, M. J. (1999), 'Interactive effects of arbuscular mycorrhizal symbiosis, intraspecific competition and resource availability on Trifolium subterraneum cv. mt. Barker', New Phytologist 141(3), 535-547.

Gardes, M. \& Bruns, T. (1993), 'ITS primers with enhanced specificity for basidiomycetes application to the identification of mycorrhizae and rusts', Molecular Ecology 2(2), $113-118$.

Hodge, A. (2004), 'The plastic plant: root responses to heterogeneous supplies of nutrients', New Phytologist 162(1), 9-24.

Jacob, A., Hertel, D. \& Leuschner, C. (2012), 'On the significance of belowground overyielding in temperate mixed forests: separating species identity and species diversity effects', Oikos 1-11. In Press. Online Access 11.09.2012.

Jakobsen, I., Abbott, L. K. \& Robson, A. D. (1992), 'External hyphae of vesicular-arbuscular mycorrhizal fungi associated with Trifolium subterraneum L.', New Phytologist 120(3), 371-380.

Jones, M. D., Durall, D. M. \& Tinker, P. B. (1998), 'A comparison of arbuscular and ectomycorrhizal Eucalyptus coccifera: growth response, phosphorus uptake efficiency and external hyphal production', New Phytologist 140, 125-134.

Lang, C. \& Polle, A. (2011), 'Ectomycorrhizal fungal diversity, tree diversity and root nutrient relations in a mixed central european forest', Tree Physiology 31(5), 531-538.

Lang, C., Seven, J. \& Polle, A. (2011), 'Host preferences and differential contributions of deciduous tree species shape mycorrhizal species richness in a mixed Central European forest', Mycorrhiza 21(4), 297-308.

Leuschner, C., Hertel, D., Coners, H. \& Büttner, V. (2001), 'Root competition between beech and oak: a hypothesis', Oecologia 126, 276-284.

Lilleskov, E. A., Fahey, T. J., Horton, T. R. \& Lovett, G. M. (2002), 'Belowground ectomycorrhizal fungal community change over a nitrogen deposition gradient in Alaska', Ecology 83, 104-115. 
Martin, F., Aerts, A., Ahrén, D., Brun, A., Danchin, E. G. J., Duchaussoy, F., Gibon, J., Kohler, A., Lindquist, E., Pereda, V., Salamov, A., Shapiro, H. J., Wuyts, J., Blaudez, D., Buée, M., Brokstein, P., Canbäck, B., Cohen, D., Courty, P. E., Coutinho, P. M., Delaruelle, C., Detter, J. C., Deveau, A., DiFazio, S., Duplessis, S., Fraissinet-Tachet, L., Lucic, E., Frey-Klett, P., Fourrey, C., Feussner, I., Gay, G., Grimwood, J., Hoegger, P. J., Jain, P., Kilaru, S., Labbé, J., Lin, Y. C., Legué, V., Tacon, F. L., Marmeisse, R., Melayah, D., Montanini, B., Muratet, M., Nehls, U., Niculita-Hirzel, H., Oudot-Le Secq, M. P., Peter, M., Quesneville, H., Rajashekar, B., Reich, M., Rouhier, N., Schmutz, J., Yin, T., Chalot, M., Henrissat, B., Kües, U., Lucas, S., de Peer, Y. V., Podila, G. K., Polle, A., Pukkila, P. J., Richardson, P. M., Rouzé, P., Sanders, I. R., Stajich, J. E., Tunlid, A., Tuskan, G. \& Grigoriev, I. V. (2008), 'The genome of Laccaria bicolor provides insights into mycorrhizal symbiosis', Nature 452(7183), 88-92.

McGonigle, T. P., Miller, M. H., Evans, D. G., Fairchild, G. L., Swan, A (1990), 'A new method which gives an objective measure of colonization of roots by vesiculararbuscular mycorrhizal fungi', New Phytologist 115, 495-501.

McGuire, K. L. (2007), 'Common ectomycorrhizal networks may maintain monodominance in a tropical rain forest', Ecology 88(3), 567-574.

Meinen, C., Hertel, D. \& Leuschner, C. (2009), 'Biomass and morphology of fine roots in temperate broad-leaved forests differing in tree species diversity: is there evidence of below-ground overyielding?', Oecologia 161(1), 99-111.

Nagy, R., Karandashov, V., Chague, V., Kalinkevich, K., Tamasloukht, M., Xu, G., Jakobsen, I., Levy, A. A., Amrhein, N. \& Bucher, M. (2005), 'The characterization of novel mycorrhiza-specific phosphate transporters from Lycopersicon esculentum and Solanum tuberosum uncovers functional redundancy in symbiotic phosphate transport in Solanaceous species.', The Plant Journal 42(2), 236-250.

Peuke, A. D. \& Rennenberg, H. (2004), 'Carbon, nitrogen, phosphorus, and sulphur concentration and partitioning in beech ecotypes (Fagus sylvatica): phosphorus most affected by drought', Trees - Structure and Function 18, 639-648.

Phillips, J. M., Hayman, D. S. (1970), 'Improved procedures for clearing roots and staining parasitic and vesicular-arbuscular mycorrhizal fungi for rapid assessment of infection', Transactions of the British Mycological Society 55, 158-160.

Plassard, C. \& Dell, B. (2010), 'Phosphorus nutrition of mycorrhizal trees', Tree Physiology 30(9), 1129-1139.

Rausch, C. \& Bucher, M. (2002), 'Molecular mechanisms of phosphate transport in plants', Planta 216, 23-37.

Richardson, A. E., Barea, J.-M., McNeill, A. M. \& Prigent-Combaret, C. (2009), 'Acquisition of phosphorus and nitrogen in the rhizosphere and plant growth promotion by microorganisms', Plant and Soil 321(1-2), 305-339. 
Rust, S. \& Savill, P. (2000), 'The root systems of Fraxinus excelsior and Fagus sylvatica and their competitive relationships', Forestry 73(5), 499-508.

Schachtman, Reid \& Ayling (1998), 'Phosphorus uptake by plants: from soil to cell', Plant Physiology 116(2), 447-453.

Scheublin, T. R., van Logtestijn, R. S. P. \& van der Heijden, M. G. A. (2007), 'Presence and identity of arbuscular mycorrhizal fungi influence competitive interactions between plant species', Journal of Ecology 95(4), 631-638.

Selosse, M.-A., Richard, F., He, X. \& Simard, S. W. (2006), 'Mycorrhizal networks: des liaisons dangereuses?', Trends in Ecology and Evolution 21(11), 621-628. Smith, S.

E. \& Read, D. J. (2008), Mycorrhizal Symbiosis, $3^{\text {rd }}$ edn, Academic Press, London.

Smith, S. E., Smith, F. A. \& Jakobsen, I. (2003), 'Mycorrhizal fungi can dominate phosphate supply to plants irrespective of growth responses', Plant Physiology 133(1), 16-20.

Tatry, M.-V., Kassis, E. E., Lambilliotte, R., Corratgé, C., van Aarle, I., Amenc, L. K., Alary, R., Zimmermann, S., Sentenac, H. \& Plassard, C. (2009), 'Two differentially regulated phosphate transporters from the symbiotic fungus Hebeloma cylindrosporum and phosphorus acquisition by ectomycorrhizal Pinus pinaster', The Plant Journal 57(6), 1092-1102.

Team, R. D. C. (2008), R: A language and environment for statistical computing. R Foundation for Statistical Computing, Vienna, Austria. http://www.R-project.org. Access date:28.11.2012.

Teste, F. P. \& Simard, S. W. (2008), 'Mycorrhizal networks and distance from mature trees alter patterns of competition and facilitation in dry Douglas-fir forests', Oecologia 158(2), 193-203.

Treseder, K. K. (2004), 'A meta-analysis of mycorrhizal responses to nitrogen, phosphorus, and atmospheric $\mathrm{CO}_{2}$ in field studies', New Phytologist 164(2), 347-355.

van der Heijden, E. W. (2001), 'Differential benefits of arbuscular mycorrhizal and ectomycorrhizal infection of Salix repens', Mycorrhiza 10(4), 185-193.

van der Heijden, M. G. A. \& Horton, T. R. (2009), 'Socialism in soil? The importance of mycorrhizal fungal networks for facilitation in natural ecosystems', Journal of Ecology 97(6), 1139-1150.

Wardle, D. A., Walker, L. R. \& Bardgett, R. D. (2004), 'Ecosystem properties and forest decline in contrasting long-term chronosequences', Science 305(5683), 509-513.

White, T., Bruns, T., Lee, S. \& Taylor, J. (1990), 'Amplification and direct sequencing of fungal ribosomal RNA genes for phylogenetics', In: PCR protocols: a guide to methods and applications, Academic Press, New York, 315-322.

White, P. J. \& Hammond, J. P. (2008), Plant Ecophysiology 7, Springer Verlag, Berlin. 
Supplementary data

Supplement Table S1: Mycorrhizal colonization of beech (Fagus sylvatica; ECM) and ash (Fraxinus excelsior; AM) grown in monoculture and two species mixture

Supplement Table S2: Molecular information on ectomycorrhizal (EM) species. EM fungi were identified by ITS sequencing and sequence information was deposited in NCBI databank. If the homology was higher than $97 \%$ and the score higher than 700 bits, the name suggested by the database, preferentially that of UNITE was quoted. If the score was higher than 600, the homology more than $95 \%$ and both databases suggested the same genus, the species was named as unknown species of the suggested genus.

Supplement Table S3:Root length (RL), specific root length (SRL), specific surface area (SSA), and average root diameter (AD) of fine roots $(\varnothing \leq 2 \mathrm{~mm})$ of ash and beech saplings grown in monocultures and two species mixtures

Supplement Table S4: The lenght $(\mathrm{cm})$, area $\left(\mathrm{cm}^{2}\right)$, volume $\left(\mathrm{cm}^{3}\right)$ and number of root tips $(\mathrm{n})$ of fine roots of beech (Fagus sylvatica) and ash (Fraxinus excelsiot) divided in 11 classes.

Supplement Table S5: Fine root architecture of beech and ash saplings grown in monoculture and in two species mixture. The number of root tips, -forks and -crossings in relation to root length

Supplement Table S6: Nutrient element concentrations in beech (Fagus syvatica) and ash (Fraxinus excelsior) fine roots and leafs

Supplement Table S7: Biometrical parameters of ash and beech grown in monoculture (mono) and two species mixture (mix) 
Supplement Table S1: Mycorrhizal colonization of beech (Fagus sylvatica; EM) and ash (Fraxinus excelsior; AM) grown in monoculture and two species mixture

\begin{tabular}{lllll}
\hline Species & Treatment & $\mathrm{n}$ & $\%$ & \\
\hline Mycorrhizal root tips & & & & \\
F. sylvatica & mono & 34 & 68.7 & $\pm 4 \mathrm{a}$ \\
F. excelsior & mono & 14 & 75.8 & $\pm 3 \mathrm{a}$ \\
& & & & \\
F. sylvatica & mix & 20 & 70.5 & $\pm 5 \mathrm{a}$ \\
F. excelsior & mix & 11 & 75.3 & $\pm 4 \mathrm{a}$
\end{tabular}

Data indicates means $( \pm \mathrm{SE})$. Different letters in columns indicate significant differences among treatments with $P \leq 0.05$. Statistics was performed with Kruskal-Wallis test. To determine ECM colonization of the root tips, in each sample 1000 vital root tips were counted. The percentage of ECM colonization was calculated as: ECM root tips/(ECM root tips + non mycorrhizal root tips) $x 100$. 
Supplement Table S2: Molecular information on ectomycorrhizal (EM) species. EM fungi were identified by ITS sequencing and sequence information was deposited in NCBI databank. If the homology was higher than $97 \%$ and the score higher than 700 bits, the name suggested by the database, preferentially that of UNITE was quoted. If the score was higher than 600, the homology more than $95 \%$ and both databases suggested the same genus, the species was named as unknown species of the suggested genus. ACC = Accession number in NCBI databank, Best BLAST match $=$ name obtained from NCBI or UNITE

\begin{tabular}{|c|c|c|c|c|c|c|c|c|}
\hline & $\mathrm{ACC}$ & $\begin{array}{c}\text { Length of } \\
\text { Fragment } \\
\text { [letters] }\end{array}$ & Best BLAST Match & Source & Strain Identity & Identities & $\begin{array}{l}\text { Homo } \\
\text { logy } \\
{[\%]} \\
\end{array}$ & $\begin{array}{l}\text { Score } \\
\text { [bits] }\end{array}$ \\
\hline Hebeloma velutipes & JX844784 & 597 & Hebeloma velutipes & UNITE & UDB000022 & $595 / 597$ & 99 & 1172 \\
\hline Paxillus involutus & JX844778 & 668 & Paxillus involutus & UNITE & UDB000754 & $642 / 642$ & 100 & 1273 \\
\hline Paxillus involutus & JX844779 & 707 & Paxillus involutus & UNITE & UDB000754 & $654 / 654$ & 100 & 1296 \\
\hline Rhizoscyphus sp. & JX844782 & 569 & $\begin{array}{l}\text { Uncultured } \\
\text { (Rhizoscyphus) }\end{array}$ & NCBI & HQ211588.1 & $566 / 569$ & 99 & 1035 \\
\hline Sebacina sp. 1 & JX844771 & 651 & Uncultured EM (Sebacina) & NCBI & HQ212339.1 & $633 / 653$ & 97 & 1090 \\
\hline Sebacina sp. 1 & JX844775 & 568 & UnculturedEM (Sebacina) & $\mathrm{NCBI}$ & $\underline{\mathrm{HQ} 212339.1}$ & $551 / 569$ & 97 & 948 \\
\hline Sebacina sp. 1 & JX844773 & 560 & Uncultured EM (Sebacina) & NCBI & HQ212339.1 & $542 / 561$ & 97 & 928 \\
\hline Sebacina sp. 2 & JX844772 & 622 & Uncultured EM (Sebacina) & $\mathrm{NCBI}$ & HQ212355.1 & $604 / 622$ & 97 & 1046 \\
\hline Sebacina sp. 2 & JX844774 & 516 & Uncultured EM (Sebacina) & NCBI & HQ212355.1 & $502 / 516$ & 97 & 874 \\
\hline Tomentella badia & JX844776 & 704 & Tomentella badia & UNITE & UDB000952 & $544 / 546$ & 99 & 1070 \\
\hline Tomentella castanea & JX844764 & 619 & Tomentella castanea & UNITE & UDB000120 & $608 / 608$ & 100 & 1205 \\
\hline Tomentella castanea & JX844765 & 575 & Tomentella castanea & UNITE & UDB000120 & $575 / 575$ & 100 & 1140 \\
\hline Tomentella castanea & JX844767 & 668 & Tomentella castanea & UNITE & UDB000120 & $668 / 668$ & 100 & 1324 \\
\hline Tomentella castanea & JX844768 & 668 & Tomentella castanea & UNITE & UDB000120 & $668 / 668$ & 100 & 1324 \\
\hline Tomentella castanea & JX844769 & 668 & Tomentella castanea & UNITE & UDB000120 & $532 / 532$ & 100 & 1055 \\
\hline Tomentella castanea & JX844770 & 668 & Tomentella castanea & UNITE & UDB000120 & $637 / 637$ & 100 & 1263 \\
\hline Tuber sp. & JX844780 & 621 & Uncultured EM (Tuber) & NCBI & HQ204753.1 & $618 / 621$ & 99 & 1131 \\
\hline Uncultured EM MT10 & JX844777 & 782 & Uncultured EM fungus & NCBI & DQ233812.1 & $776 / 782$ & 99 & 1411 \\
\hline Unknown EM MT18 & JX844781 & 559 & Sphaerosporella brunnea & UNITE & UDB000994 & $345 / 368$ & 93 & 541 \\
\hline uncultured Helotiales & JX844783 & 466 & Uncultured EM (Helotiales) & NCBI & FJ475652.1 & $459 / 467$ & 98 & 718 \\
\hline
\end{tabular}


Supplemen Table S3: Root length (RL), specific root length (SRL), specific surface area (SSA) and average root diameter (AD)

\begin{tabular}{|c|c|c|c|c|c|}
\hline Tree species & treatment & SRL $\left[\mathrm{cm} \mathrm{g}^{-1}\right]$ & $\mathrm{SSA}\left[\mathrm{cm}^{2} \mathrm{~g}^{-1}\right]$ & & $\mathrm{D}[\mathrm{cm}]$ \\
\hline F. sylvatica & mono & $5282.1 \pm 290 \mathrm{a}$ & $459.8 \pm 24.1 \mathrm{a}$ & 0.028 & $\pm 0.001 \mathrm{a}$ \\
\hline F. Excelsior & mono & $3251.6 \pm 166 b$ & $393.9 \pm 18.4 \mathrm{a}$ & 0.039 & $\pm 0.001 b$ \\
\hline F. sylvatica & $\operatorname{mix}$ & $5989.2 \pm 467 \mathrm{a}$ & $494.6 \pm 46.0 \mathrm{a}$ & 0.026 & $\pm 0.001 \mathrm{a}$ \\
\hline F. Excelsior & $\operatorname{mix}$ & $3591.9 \pm 182 b$ & $429.6 \pm 18.3 \mathrm{a}$ & 0.038 & $\pm 0.001 \mathrm{~b}$ \\
\hline
\end{tabular}

Data shows means $(n=20-36 \pm$ SE). Different letters in columns indicate significant differences among treatments with $P \leq 0.05$ (Kruskal-Wallis test and post hoc tests with Wilcoxon rank sum test). 
Supplement Table S4: The lenght $(\mathrm{cm})$, area $\left(\mathrm{cm}^{2}\right)$, volume $\left(\mathrm{cm}^{3}\right)$ and number of root tips $(\mathrm{n})$ of fine roots of beech $($ Fagus sylvatica) and ash (Fraxinus excelsiot) grown in monocultures (mo) and mixtures (mi) divided in 11 classes

\begin{tabular}{|c|c|c|c|c|c|c|c|c|c|c|c|c|c|c|c|c|c|c|c|c|c|c|c|}
\hline Species & $\begin{array}{l}\text { Tr } \\
\text { eat }\end{array}$ & \multicolumn{2}{|c|}{ class 1} & \multicolumn{2}{|c|}{ class 2} & \multicolumn{2}{|c|}{ class 3} & \multicolumn{2}{|c|}{ class 4} & \multicolumn{2}{|c|}{ class 5} & \multicolumn{2}{|c|}{ class 6} & \multicolumn{2}{|c|}{ class 7} & \multicolumn{2}{|c|}{ class 8} & \multicolumn{2}{|c|}{ class 9} & \multicolumn{2}{|c|}{ class 10} & \multicolumn{2}{|c|}{ class 11} \\
\hline $\begin{array}{c}\text { Root area } \\
{\left[\mathrm{cm}^{2}\right]}\end{array}$ & & \multicolumn{2}{|c|}{$0.0<-\leq 0.2$} & \multicolumn{2}{|c|}{$0.2<-\leq 0.4$} & \multicolumn{2}{|c|}{$0.4<-\leq 0.6$} & \multicolumn{2}{|c|}{$0.6<-\leq 0.8$} & \multicolumn{2}{|c|}{$0.8<-\leq 1.0$} & \multicolumn{2}{|c|}{$1.0<-\leq 1.2$} & \multicolumn{2}{|c|}{$1.2<-\leq 1.4$} & \multicolumn{2}{|c|}{$1.4<-\leq 1.6$} & \multicolumn{2}{|c|}{$1.6<-\leq 1.8$} & \multicolumn{2}{|c|}{$1.8<-\leq 2.0$} & \multicolumn{2}{|r|}{$>2.0$} \\
\hline$\overline{F . \text { sylvatica }}$ & mo & 4.7 & $\pm 0.3 \mathrm{a}$ & 5.8 & $\pm 0.4 \mathrm{a}$ & 4.31 & $\pm 0.3 \mathrm{ab}$ & 1.13 & $\pm 0.1 \mathrm{a}$ & 0.79 & $\pm 0.1 \mathrm{a}$ & 0.32 & $\pm 0.1 \mathrm{a}$ & 0.07 & $\pm 0.02 \mathrm{ab}$ & 0.07 & $\pm 0.01 \mathrm{a}$ & 0.03 & $\pm 0.01 \mathrm{a}$ & 0.01 & $\pm 0.00 \mathrm{a}$ & 0.03 & $\pm 0.01 \mathrm{a}$ \\
\hline F.excelsior & mo & 0.3 & $\pm 0.0 \mathrm{~b}$ & 8.2 & $\pm 0.7 \mathrm{~b}$ & 4.81 & $\pm 0.4 \mathrm{~b}$ & 0.83 & $\pm 0.1 \mathrm{a}$ & 0.3 & $\pm 0.1 \mathrm{~b}$ & 0.26 & $\pm 0.1 \mathrm{~b}$ & 0.05 & $\pm 0.02 \mathrm{~b}$ & 0.03 & $\pm 0.01 \mathrm{~b}$ & 0.01 & $\pm 0.01 \mathrm{~b}$ & 0.00 & $\pm 0.00 \mathrm{~b}$ & 0.01 & $\pm 0.01 \mathrm{~b}$ \\
\hline F. sylvatica & $\mathrm{mi}$ & 5.2 & $\pm 0.5 \mathrm{a}$ & 6.8 & $\pm 0.8 \mathrm{ab}$ & 3.81 & $\pm 0.3 \mathrm{a}$ & 0.82 & $\pm 0.1 \mathrm{a}$ & 0.51 & $\pm 0.1 \mathrm{ab}$ & 0.25 & $\pm 0.1 \mathrm{ab}$ & 0.08 & $\pm 0.02 \mathrm{a}$ & 0.03 & $\pm 0.01 \mathrm{ac}$ & 0.03 & $\pm 0.01 \mathrm{a}$ & 0.01 & $\pm 0.01 \mathrm{a}$ & 0.03 & $\pm 0.01 \mathrm{a}$ \\
\hline F. excelsior & $\mathrm{mi}$ & 0.4 & $\pm 0.0 \mathrm{~b}$ & 9.8 & $\pm 1.0 \mathrm{~b}$ & 5.65 & $\pm 0.4 \mathrm{~b}$ & 0.76 & $\pm 0.1 \mathrm{a}$ & 046 & $\pm 0.1 \mathrm{~b}$ & 0.20 & $\pm 0.1 \mathrm{ab}$ & 0.06 & $\pm 0.02 \mathrm{ab}$ & 0.02 & $\pm 0.01 \mathrm{bc}$ & 0.01 & $\pm 0.01 \mathrm{~b}$ & 0.00 & $\pm 0.00 \mathrm{ab}$ & 0.01 & $\pm 0.00 \mathrm{ab}$ \\
\hline $\begin{array}{l}\text { Root length } \\
{[\mathrm{cm}]}\end{array}$ & & \multicolumn{2}{|c|}{$0.0<-. \leq 0.2$} & \multicolumn{2}{|c|}{$0.2<-\leq 0.4$} & \multicolumn{2}{|c|}{$0.4<-\leq 0.6$} & \multicolumn{2}{|c|}{$0.6<-\leq 0.8$} & \multicolumn{2}{|c|}{$0.8<-\leq 1.0$} & $1.0<$ & $-\leq 1.2$ & & $-\leq 1.4$ & & $-\leq 1.6$ & & $-\leq 1.8$ & & $-\leq 2.0$ & & $>2.0$ \\
\hline F. sylvatica & mo & 116.2 & $\pm 6.4 \mathrm{a}$ & 51.1 & $\pm 3.3 \mathrm{a}$ & 21.5 & $\pm 1.5 \mathrm{a}$ & 4.11 & $\pm 0.4 \mathrm{a}$ & 2.28 & $\pm 0.3 \mathrm{a}$ & 0.74 & $\pm 0.1 \mathrm{a}$ & 0.13 & $\pm 0.03 \mathrm{ab}$ & 0.11 & $\pm 0.02 \mathrm{a}$ & 0.05 & $\pm 0.01 \mathrm{a}$ & 0.01 & $\pm 0.01 \mathrm{a}$ & 0.02 & $\pm 0.00 \mathrm{a}$ \\
\hline F.excelsior & mo & 8.7 & $\pm 1.0 \mathrm{~b}$ & 80.9 & $\pm 6.7 \mathrm{~b}$ & 29.5 & $\pm 2.2 \mathrm{~b}$ & 3.63 & $\pm 0.3 \mathrm{a}$ & 1.83 & $\pm 0.3 \mathrm{a}$ & 0.70 & $\pm 0.2 \mathrm{a}$ & 0.12 & $\pm 0.03 \mathrm{~b}$ & 0.05 & $\pm 0.02 \mathrm{~b}$ & 0.02 & $\pm 0.01 \mathrm{~b}$ & 0.00 & $\pm 0.00 \mathrm{~b}$ & 0.01 & $\pm 0.01 \mathrm{~b}$ \\
\hline F. sylvatica & $\mathrm{mi}$ & 127.6 & $\pm 12.3 \mathrm{a}$ & 61.3 & $\pm 7.9 \mathrm{a}$ & 19.5 & $\pm 1.7 \mathrm{a}$ & 3.00 & $\pm 0.4 \mathrm{a}$ & 1.49 & $\pm 0.2 \mathrm{a}$ & 0.59 & $\pm 0.1 \mathrm{a}$ & 0.16 & $\pm 0.03 \mathrm{a}$ & 0.06 & $\pm 0.01 \mathrm{ab}$ & 0.04 & $\pm 0.01 \mathrm{a}$ & 0.02 & $\pm 0.01 \mathrm{a}$ & 0.02 & $\pm 0.01 \mathrm{a}$ \\
\hline F. excelsior & $\mathrm{mi}$ & 11.1 & $\pm 1.3 \mathrm{~b}$ & 95.8 & $\pm 10.3 \mathrm{~b}$ & 34.9 & $\pm 2.8 \mathrm{~b}$ & 3.34 & $\pm 0.4 \mathrm{a}$ & 1.61 & $\pm 0.2 \mathrm{a}$ & 0.56 & $\pm 0.1 \mathrm{a}$ & 0.13 & $\pm 0.04 \mathrm{ab}$ & 0.04 & $\pm 0.02 \mathrm{~b}$ & 0.02 & $\pm 0.01 \mathrm{ab}$ & 0.00 & $\pm 0.00 \mathrm{ab}$ & 0.01 & $\pm 0.00 \mathrm{ab}$ \\
\hline $\begin{array}{c}\text { Root volume } \\
{\left[\mathrm{cm}^{3}\right]}\end{array}$ & & $0.0<$ & $\leq 0.2$ & 0.2 & $\leq 0.4$ & 0.4 & $=0.6$ & 0.6 & $=0.8$ & 0 . & $-\leq 1.0$ & 1. & $=1.2$ & & $\leq 1.4$ & & $\leq 1.6$ & & $=1.8$ & & $-\leq 2.0$ & & $>2.0$ \\
\hline F. sylvatica & mo & 0.01 & $\pm 0.0 \mathrm{a}$ & 0.03 & $\pm 0.0 \mathrm{a}$ & 0.04 & $\pm 0.0 \mathrm{ab}$ & 0.01 & $\pm 0.0 \mathrm{a}$ & 0.01 & $\pm 0.0 \mathrm{a}$ & 0.01 & \pm 0.0 & 0.00 & $\pm 0.00 \mathrm{ab}$ & 0.00 & $\pm 0.00 \mathrm{a}$ & 0.00 & $\pm 0.00 \mathrm{a}$ & 0.00 & $\pm 0.00 \mathrm{a}$ & 0.00 & $\pm 0.00 \mathrm{a}$ \\
\hline F.excelsior & mo & 0.00 & $\pm 0.0 \mathrm{~b}$ & 0.06 & $\pm 0.0 \mathrm{~b}$ & 0.05 & $\pm 0.0 \mathrm{~b}$ & 0.01 & $\pm 0.0 \mathrm{a}$ & 0.01 & $\pm 0.0 \mathrm{a}$ & 0.01 & $\pm 0.0 \mathrm{a}$ & 0.00 & $\pm 0.00 \mathrm{~b}$ & 0.00 & $\pm 0.00 \mathrm{~b}$ & 0.00 & $\pm 0.00 \mathrm{~b}$ & 0.00 & $\pm 0.00 \mathrm{~b}$ & 0.00 & $\pm 0.00 \mathrm{~b}$ \\
\hline F. sylvatica & $\mathrm{mi}$ & 0.01 & $\pm 0.0 \mathrm{a}$ & 0.04 & $\pm 0.0 \mathrm{ab}$ & 0.04 & $\pm 0.0 \mathrm{a}$ & 0.01 & $\pm 0.0 \mathrm{a}$ & 0.01 & \pm 0.0 & 0.01 & $\pm 0.0 \mathrm{a}$ & 0.00 & $\pm 0.00 \mathrm{a}$ & 0.00 & $\pm 0.00 \mathrm{ab}$ & 0.00 & $\pm 0.00 \mathrm{a}$ & 0.00 & $\pm 0.00 \mathrm{a}$ & 0.00 & $\pm 0.00 \mathrm{a}$ \\
\hline F. excelsior & $\mathrm{mi}$ & 0.00 & $\pm 0.0 \mathrm{~b}$ & 0.07 & $\pm 0.0 \mathrm{~b}$ & 0.06 & $\pm 0.0 \mathrm{~b}$ & 0.01 & $\pm 0.0 \mathrm{a}$ & 0.01 & $\pm 0.0 \mathrm{a}$ & 0.00 & $\pm 0.0 \mathrm{a}$ & 0.00 & $\pm 0.00 \mathrm{ab}$ & 0.00 & $\pm 0.00 \mathrm{~b}$ & 0.00 & $\pm 0.00 \mathrm{ab}$ & 0.00 & $\pm 0.00 \mathrm{ab}$ & 0.00 & $\pm 0.00 \mathrm{ab}$ \\
\hline Root tips [n] & & $0.0<-$ & $\leq 0.2$ & 0.2 & $\leq 0.4$ & $\overline{0.4<}$ & $\leq 0.6$ & 0.6 & $\leq 0.8$ & $0.8<$ & $-\leq 1.0$ & $1.0<$ & $-\leq 1.2$ & & $-\leq 1.4$ & & $-\leq 1.6$ & & $-\leq 1.8$ & & $-\leq 2.0$ & & $>2.0$ \\
\hline F. sylvatica & mo & 536.5 & $\pm 30.4 \mathrm{a}$ & 65.3 & $\pm 9.1 \mathrm{a}$ & 10.5 & $\pm 1.2 \mathrm{a}$ & 1.93 & $\pm 0.3 \mathrm{a}$ & 1.03 & $\pm 0.2 \mathrm{a}$ & 0.27 & $\pm 0.1 \mathrm{a}$ & 0.10 & $\pm 0.07 \mathrm{a}$ & 0.00 & $\pm 0.00 \mathrm{a}$ & 0.00 & $\pm 0.00 \mathrm{a}$ & 0.03 & $\pm 0.03 \mathrm{a}$ & 0.00 & $\pm 0.00 \mathrm{a}$ \\
\hline F. excelsior & mo & 52.4 & $\pm 5.1 \mathrm{~b}$ & 59.1 & $\pm 5.1 \mathrm{a}$ & 8.53 & $\pm 0.9 \mathrm{a}$ & 1.28 & $\pm 0.2 \mathrm{a}$ & 0.72 & $\pm 0.1 \mathrm{a}$ & 0.28 & $\pm 0.1 \mathrm{a}$ & 0.08 & $\pm 0.05 \mathrm{a}$ & 0.00 & $\pm 0.00 \mathrm{a}$ & 0.03 & $\pm 0.03 \mathrm{a}$ & 0.00 & $\pm 0.00 \mathrm{a}$ & 0.00 & $\pm 0.00 \mathrm{a}$ \\
\hline F. sylvatica & $\mathrm{mi}$ & 582.6 & $\pm 56.0 \mathrm{a}$ & 76.8 & $\pm 10.4 \mathrm{a}$ & 9.59 & $\pm 1.1 \mathrm{a}$ & 0.91 & \pm 0.2 & 0.86 & $\pm 0.3 \mathrm{a}$ & 0.41 & $\pm 0.1 \mathrm{a}$ & 0.14 & $\pm 0.07 \mathrm{a}$ & 0.05 & $\pm 0.04 \mathrm{a}$ & 0.00 & $\pm 0.00 \mathrm{a}$ & 0.00 & $\pm 0.00 \mathrm{a}$ & 0.00 & $\pm 0.00 \mathrm{a}$ \\
\hline F.excelsior & $\mathrm{mi}$ & 65.3 & $\pm 6.6 \mathrm{~b}$ & 76.2 & $\pm 7.8 \mathrm{a}$ & 11.6 & $\pm 1.9 \mathrm{a}$ & 1.45 & $\pm 0.3 \mathrm{a}$ & 0.55 & $\pm 0.2 \mathrm{a}$ & 0.20 & $\pm 0.1 \mathrm{a}$ & 0.05 & $\pm 0.05 \mathrm{a}$ & 0.00 & $\pm 0.00 \mathrm{a}$ & 0.00 & $\pm 0.00 \mathrm{a}$ & 0.00 & $\pm 0.00 \mathrm{a}$ & 0.00 & $\pm 0.00 \mathrm{a}$ \\
\hline
\end{tabular}

Data shows means $(n=20-36 \pm \mathrm{SE})$. Different lower-case letters indicate significant differences between the variants at a significance level $P \leq$

0.05 (Kruskal-Wallis test, post hoc test: pairwise Wilcoxon rank sum test with $P$ value adjustment with bonferroni correction method). 
Supplement Table S5: Fine root architecture. The number of root tips, -forks and-crossings in relation to root length

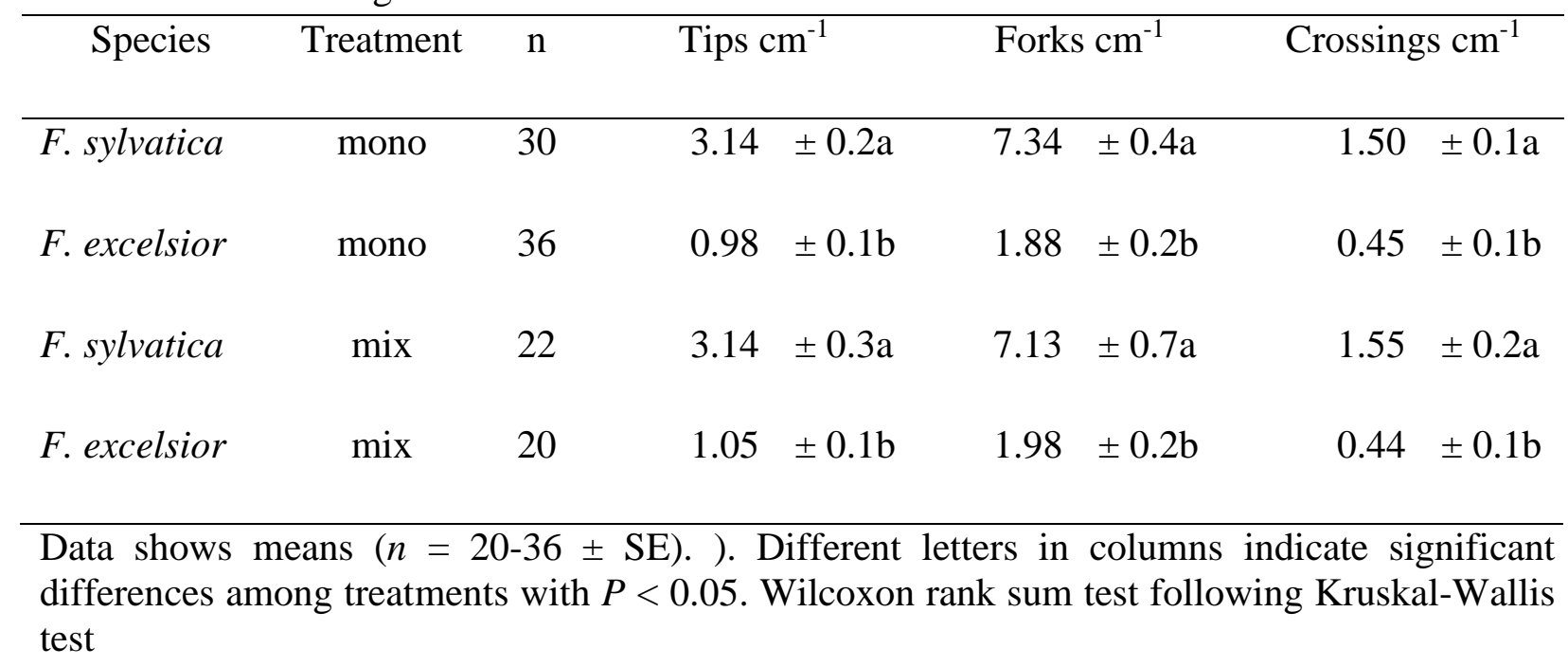


Supplement Table 6: Nutrient element concentrations in beech (Fagus syvatica) and ash (Fraxinus excelsior) fine roots and leafs

\begin{tabular}{|c|c|c|c|c|c|c|c|c|c|c|c|c|c|}
\hline Tree species & $\begin{array}{l}\text { Treat } \\
\text { ment }\end{array}$ & $\mathrm{Al}\left[\mathrm{mg} \mathrm{g}^{-1}\right]$ & $\mathrm{C}\left[\mathrm{mg} \mathrm{g}^{-1}\right]$ & $\mathrm{Ca}\left[\mathrm{mg} \mathrm{g}^{-1}\right]$ & $\mathrm{Fe}\left[\mathrm{mg} \mathrm{g}^{-1}\right]$ & $\mathrm{K}\left[\mathrm{mg} \mathrm{g}^{-1}\right]$ & $\mathrm{Mg}\left[\mathrm{mg} \mathrm{g}^{-1}\right]$ & $\mathrm{Mn}\left[\mathrm{mg} \mathrm{g}^{-1}\right]$ & $\mathrm{N}[1$ & $\operatorname{ng~g^{-1}]}$ & $\mathrm{Na}\left[\mathrm{mg} \mathrm{g}{ }^{1}\right]$ & $\mathrm{P}\left[\mathrm{mg} \mathrm{g}^{-1}\right]$ & $\mathrm{S}\left[\mathrm{mg} \mathrm{g}^{-1}\right]$ \\
\hline \multicolumn{14}{|l|}{ Fine Roots } \\
\hline F. sylvatica & mono & $3.78 \pm 0.44 \mathrm{a}$ & $433.4 \pm 6.7 \mathrm{a}$ & $5.08 \pm 0.3 \mathrm{a}$ & $2.95 \pm 0.28 \mathrm{a}$ & $3.24 \pm 0.19 \mathrm{a}$ & $1.48 \pm 0.07 \mathrm{a}$ & $3.78 \pm 0.44 \mathrm{a}$ & 10.09 & $\pm 0.19 \mathrm{a}$ & $0.66 \pm 0.15 \mathrm{a}$ & $0.73 \pm 0.02 \mathrm{a}$ & $1.48 \pm 0.07 \mathrm{a}$ \\
\hline F. excelsior & mono & $0.98 \pm 0.16 \mathrm{~b}$ & $432.4 \pm 4.8 \mathrm{a}$ & $3.38 \pm 0.1 \mathrm{~b}$ & $0.66 \pm 0.08 \mathrm{~b}$ & $9.89 \pm 0.62 b$ & $3.24 \pm 0.14 \mathrm{~b}$ & $0.23 \pm 0.16 b$ & 7.37 & $\pm 0.21 \mathrm{~b}$ & $2.86 \pm 0.23 b$ & $0.85 \pm 0.03 b$ & $3.24 \pm 0.14 \mathrm{~b}$ \\
\hline F. sylvatica & $\operatorname{mix}$ & $5.16 \pm 0.77 \mathrm{a}$ & $429.3 \pm 7.9 \mathrm{a}$ & $4.84 \pm 0.2 \mathrm{a}$ & $3.46 \pm 0.44 \mathrm{a}$ & $3.53 \pm 0.67 \mathrm{a}$ & $1.53 \pm 0.09 \mathrm{a}$ & $5.16 \pm 0.77 \mathrm{a}$ & 9.53 & $\pm 0.35 \mathrm{a}$ & $0.61 \pm 0.03 \mathrm{a}$ & $0.74 \pm 0.03 \mathrm{ab}$ & $1.53 \pm 0.09 \mathrm{a}$ \\
\hline F. excelsior & $\operatorname{mix}$ & $0.82 \pm 0.11 \mathrm{~b}$ & $430.8 \pm 8.7 \mathrm{a}$ & $3.69 \pm 0.2 b$ & $0.65 \pm 0.10 \mathrm{~b}$ & $10.1 \pm 0.51 b$ & $2.91 \pm 0.15 b$ & $0.82 \pm 0.11 \mathrm{~b}$ & 8.06 & $\pm 0.23 \mathrm{~b}$ & $2.31 \pm 0.29$ & $0.81 \pm 0.03 \mathrm{ab}$ & $2.91 \pm 0.15 b$ \\
\hline \multicolumn{14}{|l|}{ Leafs } \\
\hline F. sylvatica & mono & $0.13 \pm 0.01 \mathrm{a}$ & $471.5 \pm 8.4 \mathrm{a}$ & $6.28 \pm 0.3 \mathrm{a}$ & $0.15 \pm 0.01 \mathrm{a}$ & $5.05 \pm 0.33 \mathrm{a}$ & $1.83 \pm 0.06 \mathrm{a}$ & $0.59 \pm 0.05 \mathrm{a}$ & 11.96 & $\pm 0.42 \mathrm{a}$ & $0.17 \pm 0.01 \mathrm{a}$ & $0.75 \pm 0.03 \mathrm{a}$ & $0.82 \pm 0.03 \mathrm{a}$ \\
\hline F. excelsior & mono & $0.11 \pm 0.01 \mathrm{a}$ & $435.0 \pm 1.7 \mathrm{~b}$ & $11.1 \pm 0.7 \mathrm{~b}$ & $0.17 \pm 0.01 \mathrm{a}$ & $16.0 \pm 0.77 \mathrm{~b}$ & $4.80 \pm 0.27 b$ & $0.06 \pm 0.00 \mathrm{~b}$ & 11.14 & $\pm 0.36 \mathrm{a}$ & $0.11 \pm 0.02 b$ & $0.96 \pm 0.05 \mathrm{~b}$ & $1.73 \pm 0.10 \mathrm{~b}$ \\
\hline F. sylvatica & $\operatorname{mix}$ & $0.10 \pm 0.00 \mathrm{a}$ & $458.3 \pm 1.1 \mathrm{c}$ & $6.75 \pm 0.3 \mathrm{ac}$ & $0.15 \pm 0.01 \mathrm{a}$ & $5.31 \pm 0.82 \mathrm{a}$ & $2.11 \pm 0.15 \mathrm{a}$ & $0.71 \pm 0.09 \mathrm{a}$ & 11.50 & $\pm 0.65 \mathrm{a}$ & $0.19 \pm 0.02 \mathrm{a}$ & $0.75 \pm 0.05 \mathrm{a}$ & $0.85 \pm 0.07 \mathrm{a}$ \\
\hline F. excelsior & $\operatorname{mix}$ & $0.12 \pm 0.01 \mathrm{a}$ & $431.1 \pm 1.9 \mathrm{~b}$ & $9.22 \pm 0.9 \mathrm{bc}$ & $0.15 \pm 0.01 \mathrm{a}$ & $17.8 \pm 1.56 \mathrm{~b}$ & $4.90 \pm 0.40 \mathrm{~b}$ & $0.10 \pm 0.04 b$ & 10.69 & $\pm 0.40 \mathrm{a}$ & $0.08 \pm 0.03 b$ & $0.85 \pm 0.06 \mathrm{ab}$ & $1.54 \pm 0.15 b$ \\
\hline
\end{tabular}

Data indicates means $(n=17-27 \pm \mathrm{SE})$. Different letters in columns indicate significant differences among plant fractions with $P<0.05$. Kruskal-

Wallis test and Pairwise comparisons using Wilcoxon rank sum test. 
Supplement Table S7: Biometrical parameters of ash and beech grown in monoculture (mono) and two species mixture (mix)

\begin{tabular}{|c|c|c|c|c|c|c|c|c|c|c|c|c|c|c|c|}
\hline Tree species & Treatment & $\begin{array}{c}\text { Biomass } \\
\text { [g plant }^{-1} \text { ] }\end{array}$ & $\begin{array}{c}\text { Leaf } \\
{\left[\text { [g plant }^{-1}\right]}\end{array}$ & $\begin{array}{c}\text { Stem } \\
{\left[\text { g plant }^{-1}\right]}\end{array}$ & $\begin{array}{l}\text { Fine root } \\
\left.\text { [g plant }^{-1}\right]\end{array}$ & $\begin{array}{c}\text { Coarse Root } \\
\left.\text { [g plant }^{-1}\right]\end{array}$ & $\begin{array}{c}\text { R:S } \\
\text { Ratio }\end{array}$ & & $\begin{array}{l}\text { R:FR } \\
\text { atio }\end{array}$ & & $\begin{array}{l}\mathrm{HD} \\
\mathrm{nm}]\end{array}$ & $\begin{array}{l}\text { Shoot height }{ }^{\mathrm{a}} \\
{[\mathrm{cm}]}\end{array}$ & $\begin{array}{c}\text { Shoot } \\
\text { height }^{\text {b }} \\
{[\mathrm{cm}]}\end{array}$ & $\begin{array}{l}\text { RC } \\
{[c}\end{array}$ & $\begin{array}{l}\text { GR } \\
\text { \%] }\end{array}$ \\
\hline F. sylvatica & mono & $20.20 \pm 2 \mathrm{ab}$ & $2.41 \quad \pm 0.2 \mathrm{~b}$ & $7.07 \quad \pm 0.7 \mathrm{~b}$ & $3.73 \pm 2 \mathrm{ab}$ & $7.52 \pm 0.6 \mathrm{a}$ & $1.74 \pm 0.4 \mathrm{a}$ & 2.57 & $\pm 0.8 \mathrm{a}$ & 6.95 & $\pm 0.3 \mathrm{~b}$ & $49.07 \pm 2 b$ & $57.16 \pm 2 b$ & 1.48 & $\pm 0.2 \mathrm{a}$ \\
\hline F. excelsior & mono & $17.17 \pm 1 \mathrm{a}$ & $1.54 \pm 0.1 \mathrm{a}$ & $3.68 \pm 0.3 \mathrm{a}$ & $3.31 \pm 1 \mathrm{ab}$ & $8.64 \pm 0.3 b$ & $3.48 \pm 0.2 b$ & 2.93 & $\pm 0.2 \mathrm{~b}$ & 7.15 & $\pm 0.2 \mathrm{~b}$ & $19.52 \pm 2 \mathrm{a}$ & $33.67 \pm 2 \mathrm{a}$ & 11.02 & $\pm 1.2 \mathrm{c}$ \\
\hline F. sylvatica & mix & $13.90 \pm 2 \mathrm{a}$ & $1.94 \pm 0.3 \mathrm{ab}$ & $5.17 \pm 0.8 \mathrm{ab}$ & $2.53 \pm 1 \mathrm{a}$ & $4.27 \pm 0.3 \mathrm{a}$ & $1.52 \pm 0.1 \mathrm{a}$ & 1.83 & $\pm 0.2 \mathrm{a}$ & 5.96 & $\pm 0.3 \mathrm{a}$ & $43.28 \pm 3 b$ & $52.75 \pm 4 \mathrm{~b}$ & 2.67 & $\pm 0.7 \mathrm{a}$ \\
\hline F. excelsior & $\operatorname{mix}$ & $22.87 \pm 2 b$ & $1.98 \pm 0.1 \mathrm{~b}$ & $5.11 \pm 0.4 \mathrm{ab}$ & $4.65 \pm 1 b$ & $11.12 \pm 0.6 \mathrm{c}$ & $3.27 \pm 0.2 b$ & 2.93 & $\pm 0.3 \mathrm{~b}$ & 8.28 & $\pm 0.3 \mathrm{c}$ & $25.42 \pm 2 \mathrm{a}$ & $38.94 \pm 2 \mathrm{a}$ & 5.88 & $\pm 0.9 \mathrm{~b}$ \\
\hline
\end{tabular}

Data indicates means $( \pm \mathrm{SE})$. Different letters in columns indicate significant differences within group with $P \leq 0.05$. Statistics were performed with Wilcoxon rank sum test following Kruskal-Wallis test. Data of relative growth rate includes control plants and was calculated with RGR [\%] = $\left(\right.$ Shoot height ${ }^{\mathrm{b}}-$ Shoot height $\left.{ }^{\mathrm{a}}\right) /\left(\right.$ Shoot height $\left.{ }^{\mathrm{a} *} 10\right) * 100^{\mathrm{a}}$ Shoot length measured 10 months before the harvest, ${ }^{\mathrm{b}}$ Shoot length measured at the harvest. 


\title{
Chapter 3
}

\author{
PLANT NITROGEN ACCUMULATION \\ UNDER INTRA - AND INTERSPECIFIC \\ COMPETITION IN RELATION TO \\ PHOSPHORUS ACCUMULATION
}




\subsection{Introduction}

The benefits of mycorrhizal associations in the acquisition of the most plant growth limiting nutrients nitrogen $(\mathrm{N})$ and phosphorus $(\mathrm{P})$ have become important issues of scientific research (Correâ et al. 2012, Fellbaum et al., 2012, Kiers et al. 2011). The vast majority of the studies has focused on the acquisition of one nutrient element, but very little is known about the simultaneous uptake of multiple elements. In addition, the effects of mycorrhizal fungi on plant competition for multiple nutrients are nearly unknown. Therefore, the main objective of this study was to investigate the role of different mycorrhizal species on plant $\mathrm{N}$ and $\mathrm{P}$ acquisition.

$\mathrm{N}$ acquisition of plants presumably varies with the type of mycorrhizal association (van der Heijden et al. 2001). Especially ectomycorrhiza (EM) forming fungi have been considered to effectively increase the $\mathrm{N}$ status of plants (Smith and Read 2008). In an experiment with nonmycorrhizal and with EM inoculated Scotch pine (Pinus sylvestris L.) seedlings, root $\mathrm{N}$ concentration increased significantly in mycorrhizal seedlings compared to non-mycorrhizal plants (Colpaert et al. 1996). EM has been shown to be able to use both mineral $\mathrm{N}$ sources nitrate, $\mathrm{NO}_{3}{ }^{-}$(Nygren et al. 2008) and ammonium, $\mathrm{NH}_{4}{ }^{+}$(Chalot et al. 2006), most likely with a preference to $\mathrm{NH}_{4}^{+}$, if both $\mathrm{N}$ forms are available (Finlay et al. 1989). Furthermore, EM fungi have been reported to use a range of organic compounds as $\mathrm{N}$ sources (Chalot \& Brun 1998, Marmeisse et al. 2004).

Besides EM, certain tree species in temperate forests form arbuscular mycorrhizal (AM) associations. The relevance of these fungi to plant $\mathrm{N}$ acquisition is increasingly recognised (Fellbaum et al. 2012, Pérez-Tienda et al. 2012, Govindarajulu et al. 2005). AM fungi have been shown to take up and transport $\mathrm{NO}_{3}{ }^{-}$(Tobar et al. 1994, Govindarajulu et al. 2005), $\mathrm{NH}_{4}{ }^{+}$(Govindarajulu et al. 2005, Jin et al. 2005, Peréz-Tienda et al. 2012) and $\mathrm{N}$ from organic sources (Hawkins et al. 2000, Hodge \& Fitter 2010).

Although different mycorrhizal types might impact the $\mathrm{N}$ and $\mathrm{P}$ acquisition of co-occurring tree species unequally, surprisingly little attention has been paid to this issue. According to Tilman's (Tilman 1982) model, the nutrient utilization of two resources can lead to niche differentiation or out-competition between species (Tilman's $\mathrm{R}^{*}$ ). Species that can reduce the resource to the lowest level and maintain growth wins the competition. Co-existence is possible, when the growth of the species is differentially limited by the resources. The association with mycorrhizal fungi, and especially the different mycorrhizal types, modify the 
response of the competing plants (Aerts, 2002). It has been suggested that in non-mycorrhizal stage, plant species associated with AM fungi have a competitive advantage over plant species associated with EM fungi. This suggestion is based on the theory that plants associated with AM are characterized by more efficient $\mathrm{N}$ and $\mathrm{P}$ uptake than plants with EM (Schulz et al. 2011, Stadler et al. 1993). The mycorrhizal colonization changes the situation. Due to the presumed higher uptake capacity of EM for N, and AM for $\mathrm{P}$, the phosphorus status of ash and nitrogen status of beech increases. According to Tilman's model, both species can co-exist under these conditions.

Until now, no experimental evidence for the differences in uptake capacities of AM and EM for $\mathrm{N}$ and $\mathrm{P}$ in competition exists. An empirical study supports the theory of Aerts (2002) for differences in $\mathrm{N}$ and $\mathrm{P}$ acquisition of mycorrhizal types (Lang \& Polle 2011). Lang and Polle (2011) demonstrated that root $\mathrm{P}$ concentration of beech decreased and $\mathrm{P}$ concentration of ash increased by increasing root diversity, suggesting interspecific competition for P. In addition, $\mathrm{N}$ acquisition was related with EM diversity. In a mixed stand, fine root $\mathrm{N}$ concentration of ash decreased with increasing EM diversity of beech roots. This result indicates that EM influences the competition for $\mathrm{N}$ in tree species mixture (Lang \& Polle 2011).

It has been speculated, that the dominance of EM tree species in temperate and boreal forests, which are characterised by a strong limitation of $\mathrm{N}$ availability, might rely on a more effective N acquisition of EM compared to AM (Smith and Read 2008, Rennenberg et al. 2009). However, the experimental evidence is lacking to answer the question whether EM provides an advantage in both $\mathrm{N}$ and $\mathrm{P}$ acquisition over $\mathrm{AM}$ symbiosis.

This study reports the nitrogen uptake of ash and beech grown in conspecific and heterospecific pairs. Since the EM species effects on plant interactions are currently not well documented, we determined $\mathrm{N}$ acquisition in beech root tips colonised with different EM species. It is currently also unclear whether EM species with high $\mathrm{P}$ accumulation, which was documented in chapter 2, also take up $\mathrm{N}$ more efficiently than other EM species. Therefore, the relationship of $\mathrm{N}$ and $\mathrm{P}$ accumulation in $\mathrm{EM}$ roo tips was studied.

For this purpose, we used beech (Fagus sylvatica), which forms associations with EM fungi, and ash (Fraxinus excelsior), which forms associations with AM fungi. Both are common tree species in Central Europe, often co-occuring in mixed forests (Ellenberg \& Leuschner 2010, McKay et al. 1999). Since the developmental stage of the mycorrhizal association might strongly impact the plant response, we conducted a long term experiment to ensure the 
establishment of root external hyphae and mycorrhizal colonization in plant roots. Saplings were grown in conspecific and heterospecific pairs for two growing seasons. In order to analyse $\mathrm{N}$ and $\mathrm{P}$ uptake, we labelled the saplings for one, four or eight days with a nutrient solution containing $4 \mathrm{mM}^{15} \mathrm{NO}_{3}{ }^{15} \mathrm{NH}_{4}$ and $3.7 \mathrm{MBq} \mathrm{H}_{3}{ }^{33} \mathrm{PO}_{4}$. Subsequently we measured ${ }^{15} \mathrm{~N}$, ${ }^{33} \mathrm{P}$ and total $\mathrm{N}$ and $\mathrm{P}$ in leaves, fine roots, vital root tips (ash) as well as in mycorrhizal and non-mycorrhizal root tips (beech)

We hypothesised that (1) Nitrogen uptake of beech and ash differ in heterospecific and conspecific pairs in nutrient limited system (2) the high accumulation of P found in some EM species (Chapter 2) relate with a high accumulation for $\mathrm{N}$. 


\subsection{Material and Methods}

\subsubsection{Plant material}

The plant material and procedures have been described in chapter 2 and are therefore here only briefly reported. Beech (Fagus sylvatica), and ash (Fraxinus excelsior) seeds were germinated in June 2007 (beech) and June 2009 (ash) (Forstsaatgut-Beratungsstelle Nds. FoA Oerrel, Germany), and grown in sand-peat mixture. In June 2010 saplings of comparable size were planted in conspecific (As-As, Be-Be) and heterospecific pairs (As-Be) in pots containing a mixture 4.5:4.5:1 fine sand $(0.71-1.25 \mathrm{~mm})$, coarse sand $(0.4-0.8 \mathrm{~mm})$ and peat.

Saplings were grown together for two vegetation periods (June 2010 to August 2011) in a shaded and wind protected outdoor area. Plants were watered regularly and fertilized every second day from 01.10.2010 to 31.12.2010 with $15 \mathrm{ml}$ modified nutrient solution based on nutrient solution of Matzner et al. (1982, in Brandes 1999), containing $0.4 \mathrm{mM} \mathrm{NH} 4 \mathrm{Cl}$,

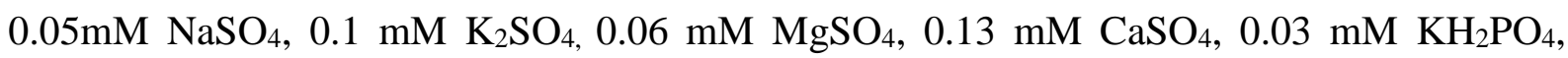
$0.005 \mathrm{mM} \mathrm{MnSO} 4$ and with $0.005 \mathrm{mM}$ of the following micronutrients: $\mathrm{H}_{3} \mathrm{BO}_{3}, \mathrm{NaMoO}_{4}$, $\mathrm{ZnSO}_{4}, \mathrm{CuSO}_{4}$ and Fe-EDTA respectively. The plants were watered with tap water from 01.01.2011 to 19.08.2011. One week before labelling (19.08.2011), plants were moved to cabinet with constant temperature of $20^{\circ} \mathrm{C}, 16 \mathrm{~h}$ photoperiod, $90-110 \mathrm{mmol} \mathrm{m} \mathrm{m}^{-2} \mathrm{~s}^{-1}$ photosynthetically active radiation (PAR) at plant height and 60\% air humidity. Plants were supplied daily with $50 \mathrm{ml}$ demineralised water per pot.

\subsubsection{Labelling and harvest}

The saplings were labelled on day 0 with $30 \mathrm{ml}$ of the modified Matzners nutrient solution per pot, containing $3.78 \mathrm{mg} \mathrm{N}$ whereof $3.36 \mathrm{mg}{ }^{15} \mathrm{~N}$ and $0.93 \mathrm{mg} \mathrm{P}$ whereof $6.27 \mathrm{ng}{ }^{33} \mathrm{P}$ per pot. 1 , 4 and 8 days after labelling, labelled and non-labelled plants from conspecific and heterospecific mixtures were harvested. The roots were briefly washed with tap water and separated in fine root $(<2 \mathrm{~mm})$ and coarse root $(>2 \mathrm{~mm})$ fractions. Subsequently, soil and plant fractions (fine roots, coarse roots, leaves, stem and branches) were weighted. Stem length, collar diameter and the number of leaves were recorded. Aliquots of fine roots were separated, put to plastic bags with moist tissue paper and stored at $5^{\circ} \mathrm{C}$ for mycorrhizal analyses. Subsequently fine roots, mycorrhizal samples, all other plant fractions and soil aliquots were dried at $60^{\circ} \mathrm{C}$. 


\subsection{3 ${ }^{15} \mathrm{~N}$ isotope analysis and $\mathrm{N}$ uptake rate}

${ }^{15} \mathrm{~N}$ labels of fine roots, leaves, dry fine roots, vital ash fine root tips of 1. and 2. order, EM fine root tips and non-mycorrhizal beech root tips were measured. Dry plant material was homogenized with a blender (Waring Commercial Blendor, Dynamics Corporation of America, New Hartford, Connecticut, USA) and ball mill (Type MM 2, Retsch, Haan, Germany). Due to the small sample sizes, ash fine root tips, non-mycorrhizal beech fine roots and EM root tips (one EM sample containing approximately 40-100 tips) were directly used. 2 mg of the dry material were weighted into tin capsules and analyzed with a coupled system of elemental analyser (NA 1500, Carlo Erba, Mailand) and a mass spectrometer (EA NC2500 Delta Plus and EA NC1108 ConFlo III Delta C, Finnigan MAT, Bremen, Germany) at the Centre for Stable Isotope Research and Analysis, University of Göttingen. The isotopic composition was calculated as

$$
\delta_{\text {sample } i}[\% 0]=\frac{R_{\text {sample } i}-R_{\text {standard }}}{R_{\text {standard }}} * 1000
$$

where $R_{\text {sample } i}$ and $R_{\text {standard }}$ represent the stabile isotope ratios $\left({ }^{13} \mathrm{C} /{ }^{12} \mathrm{C}\right.$ and $\left.{ }^{15} \mathrm{~N} /{ }^{14} \mathrm{~N}\right)$ of the sample $i$ and standards. Results are shown in the $\delta$ notation in \%o relative to the international standard PD Belemnite (PBD) for ${ }^{13} \mathrm{C}$ and atmospheric nitrogen for ${ }^{15} \mathrm{~N}$.

Specific N uptake rate was calculated for fine roots, leaves and root tips according to Schulz et al. (2011) with the equation:

$$
\mu \mathrm{g}{ }^{15} \mathrm{~N} \mathrm{~d}^{-1}(\mathrm{~g} \text { plant biomass } \mathrm{dw})^{-1}=\left[\frac{\left(\mathrm{a}_{1}-\mathrm{a}_{0}\right) * \mathrm{~N} \%}{t}\right] * 100
$$

whereby $\mathrm{a}_{1}$ and $\mathrm{a}_{0}$ represent the atom $\%{ }^{15} \mathrm{~N}$ concentrations of the plant fractions in labelled plants and non-labelled control plants. The atom\% is calculated as

$$
\text { atom } \%{ }^{13} \mathrm{C}=\frac{{ }^{13} \mathrm{C}}{{ }^{13} \mathrm{C}+{ }^{12} \mathrm{C}} * 100
$$

and $\mathrm{N} \%$ is the total $\mathrm{N}$ concentration and $t$ is the time between ${ }^{15} \mathrm{~N}$ labelling and harvest date. 
The enrichment of ${ }^{15} \mathrm{~N}$ in root tips was expressed as atom\%excess

$$
\mathrm{APE}_{15} \mathrm{~N}=\left(\text { atom } \%_{\text {labelled-atom }} \%_{\text {unlabelled }}\right) * 100
$$

\subsection{4 ${ }^{33}$ P Analysis}

The radiation of radioactive isotopes in mycorrhizal root tips was measured with a liquid scintillation analyzer (Tri-Carb 2800TR Counter, Perkin Elmer Life Sciences, RodgauJügesheim, Germany), as described previously in chapter 2.

\subsubsection{Mycorrhizal analysis}

Root tips were examined under a stereomicroscope (Leica M205 FA, Leica Microsystems, Wetzlar, Germany) and divided to vital and dry tips according to their colour and consistence. The EM mycorrhizal colonization was calculated, the EM root tips morphotyped, abundances recorded and the morphotypes photographed as described previously (chapter 2). For the analysis of the relative colonization rate of ash, three lactophenole-blue stained (Schmitz et al. 1991) fine roots per sample were examined with light microscope (Axioplan with digital camera AxioCam incl. software Axiovision, Zeiss, Oberkochen, Germany) and AM colonization was calculated with the magnified intersection method described by McGonigle et al (1990).

\subsubsection{Plant growth}

The relative annual height growth (RAG) was calculated with the equation:

$$
\operatorname{RAG}[\%]=\left[\frac{\left(\mathrm{h}_{1}-\mathrm{h}_{0}\right)}{\mathrm{h}_{0}}\right] * 100
$$

whereby $\mathrm{h}_{0}=$ shoot height in August 2010 and $\mathrm{h}_{1}=$ shoot height in August 2011 at the time of the harvest.

\subsubsection{Data analysis}

The statistical analysis was performed with the software R (The R Foundation for Statistical Computing, http://www.r-project.org). Data were log-transformed to meet the assumptions of normality and variance homogeneity. We carried out analysis of variance (ANOVA) with 
Tukeys HSD test. We used treatment (As-As, Be-Be, As-Be) and days of labelling (1, 4, and 8) as main effects to examine signatures of ${ }^{15} \mathrm{~N}$ and ${ }^{13} \mathrm{C}$ as well as total $\mathrm{N}$ and $\mathrm{C}$ concentrations of plant tissues. If the data were unsuitable for ANOVA after transformation, we used a non-parametric Kruskal-Wallis test and pairwise comparisons with Wilcoxon test to detect significant differences.

Linear regression analyses were performed to evaluate the relationship of ${ }^{15} \mathrm{~N}$ signatures of fine roots and leavesas well as ${ }^{15} \mathrm{~N}$ concentrations of mycorrhizal and non-mycorrhizal fine root tips. The figures were generated with the software Origin 8.5G (Origin Lab Corp., Northampton, USA) and R 2.10.0 (Team 2008).

\subsection{Results}

\subsubsection{Total carbon and nitrogen in fine roots and leaves}

Total $\mathrm{N}$ concentrations in ash and beech leaves were similar (Tab. 3.1). According to the foliar nutrient threshold values of 19-23 $\mathrm{mg} \mathrm{g}^{-1}$ for beech (Mellert and Göttlein 2012) and 23$28 \mathrm{mg} \mathrm{g}^{-1}$ for ash (Kopinga \& van den Burg, 1995), both species were N deficient. Total N concentrations of fine roots displayed taxon related differences and were not influenced by the species identity of the neighbour.

Leaf $\mathrm{C}$ concentration of beech was higher than in ash, but decreased in mixture. Generally the $\mathrm{C}$ concentrations of fine roots were species specific. The growth in mixture increased the $\mathrm{C}$ concentration of EM root tips of the most abundant EM species (EM species mean). Nonmycorrhizal root tips of beech had the highest $\mathrm{C}$ concentrations. 
Table 3.1: $\mathrm{N}$ and $\mathrm{C}$ concentration $\left[\mathrm{mg} \mathrm{g}^{-1}\right]$ in leaves, fine roots (FR) as well as in dry, vital non mycorrhizal (NM) and mycorrhizal (EM) root tips of beech and dry and vital mycorrhizal root tips of ash fine roots grown in monoculture (mono) and two species mixture (mix)

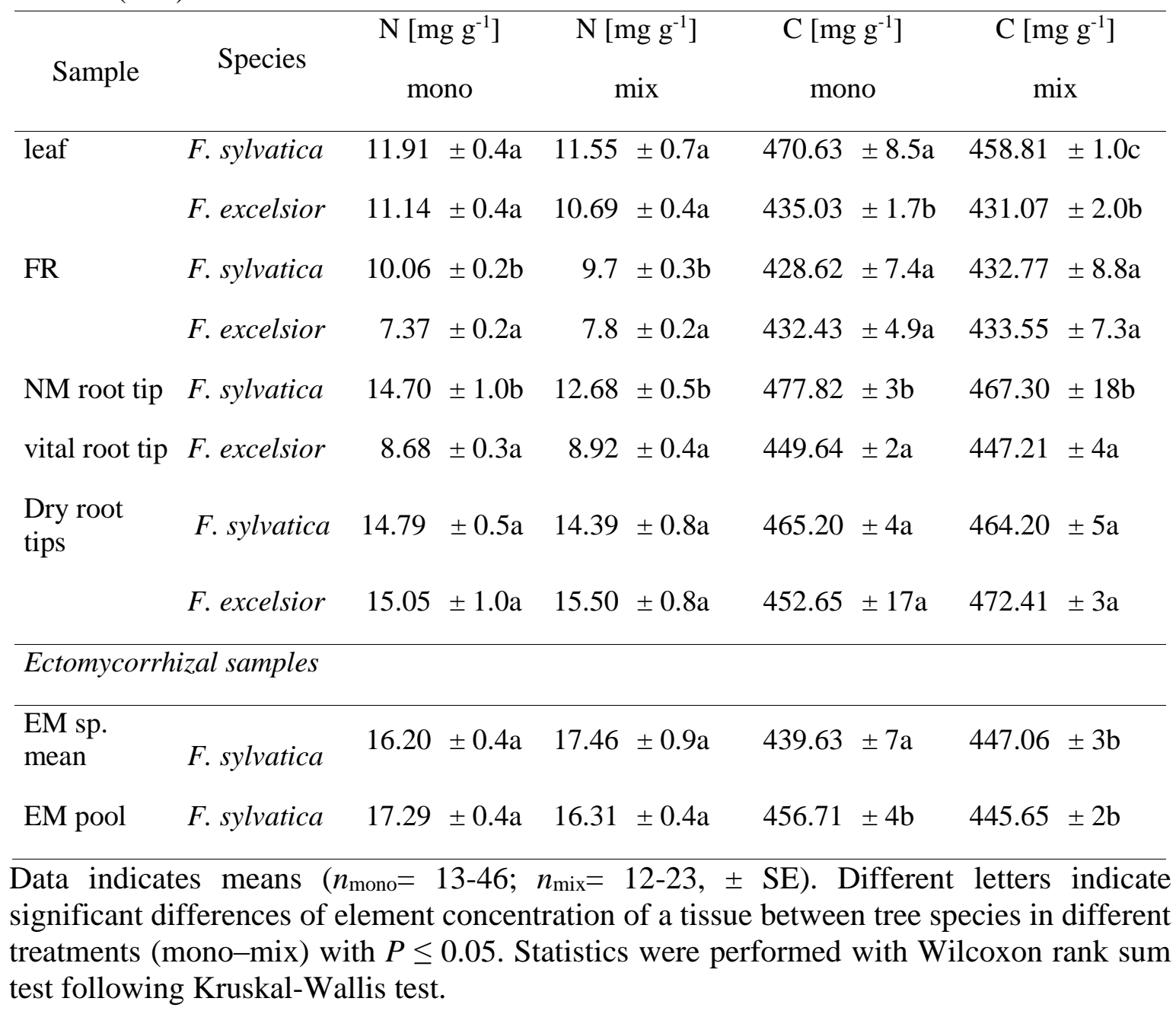

\subsection{2 ${ }^{15} \mathrm{~N}$ accumulation in leaves and fine roots}

The leaf ${ }^{15} \mathrm{~N}$ accumulation of beech and ash in monocultures displayed species differences (Fig. 3.1 A, Tab. 3.2). Leaf ${ }^{15} \mathrm{~N}$ accumulation of beech was significantly lower than in ash $(P$ $=0.012$ ). In addition, leaf ${ }^{15} \mathrm{~N}$ signature of beech did not increase remarkably during the labelling period. The signatures were however higher than in unlabelled controls $(P<0.001)$. Leaf ${ }^{15} \mathrm{~N}$ accumulation of ash decreased in mixture compared to monoculture. This resulted in similar leaf ${ }^{15} \mathrm{~N}$ labels of ash and beech in mixture $(P=0.877)$ at day 8 . Fine root ${ }^{15} \mathrm{~N}$ accumulation of ash and beech did not differ significantly over the time (Fig. 3.1 B). 

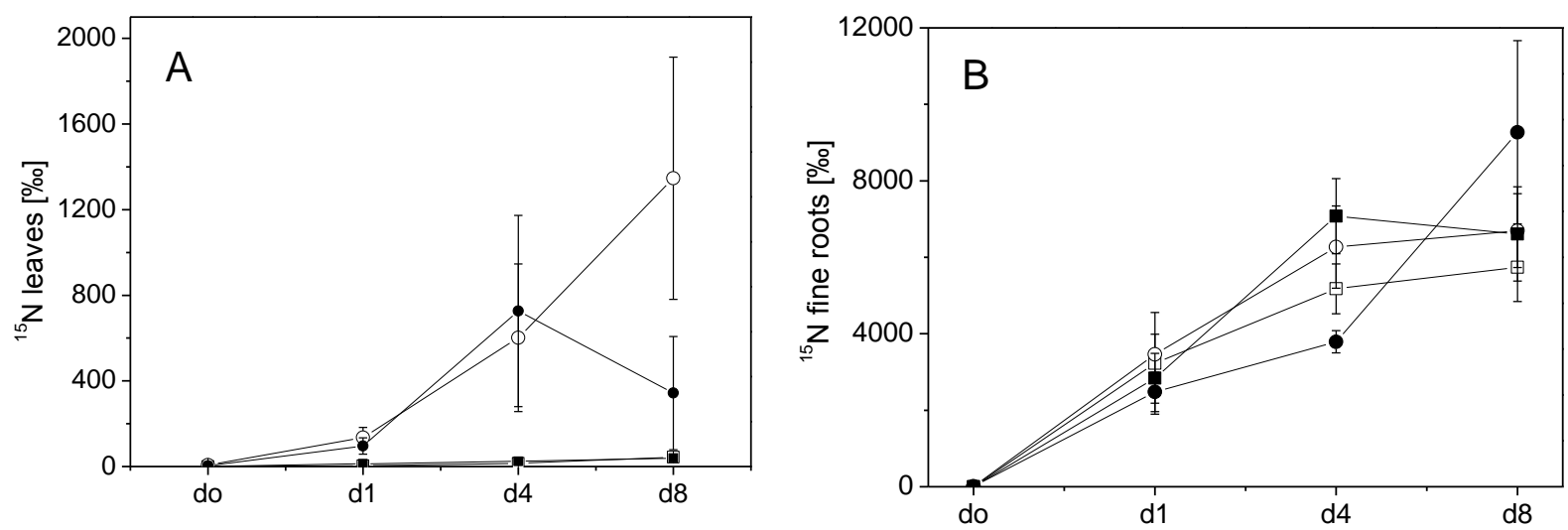

Figure 3.1: $\delta^{15} \mathrm{~N}$ accumulation in leaves (A) and fine roots (B) of beech (squares) and ash (dots) grown in monoculture (open symbols) and two species mixtures (filled symbols) during 8 days labelling.

Table 3.2: Results of ANOVA for $\delta^{15} \mathrm{~N}$ accumulation [\%o] in leaves and fine roots of beech and ash grown in monoculture and two species mixtures during 8 days labelling

\begin{tabular}{lccc}
\hline ANOVA ${ }^{15} \mathrm{~N}$ leaves [\%] & $F$ & $P$ & \\
\hline Day & 44.184 & $<0.001$ & $* * *$ \\
Species & 88.327 & $<0.001$ & $* * *$ \\
Treatment & 0.003 & 0.953 & \\
Day x Species & 2.846 & 0.042 & $*$ \\
Day x Treatment & 0.921 & 0.434 & \\
Species x Treatment & 4.221 & 0.043 & $*$ \\
Day x Species x Treatment & 0.394 & 0.758 &
\end{tabular}

\begin{tabular}{lccc}
\hline ANOVA ${ }^{15} \mathrm{~N}$ fine roots [\%o] & $F$ & $P$ & \\
\hline Day & 627.444 & $<0.001$ & $* *$ \\
Species & 2.634 & 0.626 & $*$ \\
Treatment & 0.240 & 0.049 & $*$ \\
Day x Species & 2.718 & 0.506 & \\
Day x Treatment & 0.784 & 0.133 & \\
Species x Treatment & 2.298 & 0.302 & \\
Day x Species x Treatment & 0.474 & 0.701 & \\
\hline
\end{tabular}

Beech fine root ${ }^{15} \mathrm{~N}$ accumulation was generally higher in mixture than in monoculture. However the accumulation of ${ }^{15} \mathrm{~N}$ in fine roots differed not significantly between species.

\subsection{3 ${ }^{15} \mathrm{~N}$ accumulation in fine roots tips}

In order to find out whether ${ }^{15} \mathrm{~N}$ uptake of fine root tips differs between trees grown in monoculture and mixture, we compared the mean ${ }^{15} \mathrm{~N}$ signatures of root tips (Fig. 3.2). The 
highest ${ }^{15} \mathrm{~N}$ label was found in EM root tips. In monoculture NM beech fine root tips and vital ash fine root tips accumulated ${ }^{15} \mathrm{~N}$ similarly $(P=0.219)$. In mixture $\mathrm{NM}$ beech root tips had higher fine $\operatorname{root}{ }^{15} \mathrm{~N}$ signatures than ash fine root tips $(P=0.039)$.

In mycorrhizal beech root tips, the $\mathrm{N}$ accumulation tended to increase in mixture. In contrast, vital ash root tips and non-mycorrhizal (NM) beech root tips tended to accumulate less ${ }^{15} \mathrm{~N}$ in mixture. The lowest ${ }^{15} \mathrm{~N}$ signatures were recorded in dead root tips of beech. Passive absorption of ${ }^{15} \mathrm{~N}$ was measured to some extent in dead root tips of both tree species.

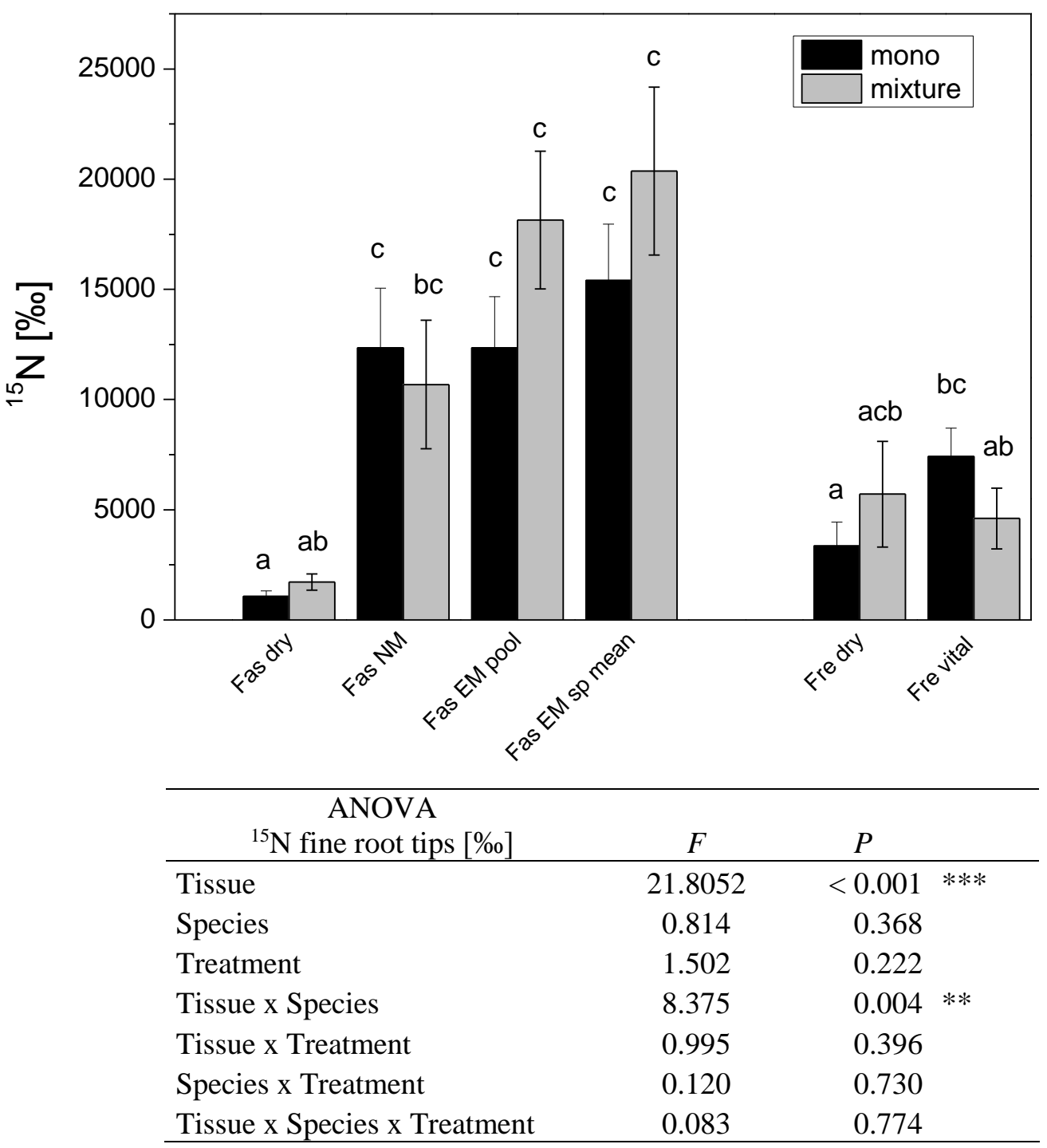

Figure 3.2: $\delta^{15} \mathrm{~N}$ enrichment (\%) in dry, vital non mycorrhizal (NM), mycorrhizal root tips of most abundant ECM species (EM sp mean), mixture of all found EM (EM pool) of beech (Fas) and dry and vital mycorrhizal root tips of ash (Fre) fine roots grown in monoculture (mono) and two species mixture (mixture). Data indicates means $(n=46-16 \pm S E$ ). Tukeys HD test following one way ANOVA with $P \leq 0.05$. 


\subsection{4 ${ }^{15} \mathrm{~N}$ accumulation in EM species}

In order to determine taxon related differences in $\mathrm{N}$ uptake in $\mathrm{EM}$ fungi, ${ }^{15} \mathrm{~N}$ accumulation was measured in beech root tips colonized with different EM species. Because no significant differences between monocultures and mixtures occurred, the mean value of both treatments is shown. Some taxon related differences were found in the ${ }^{15} \mathrm{~N}$ uptake of EM species (Fig. $3.3)$.

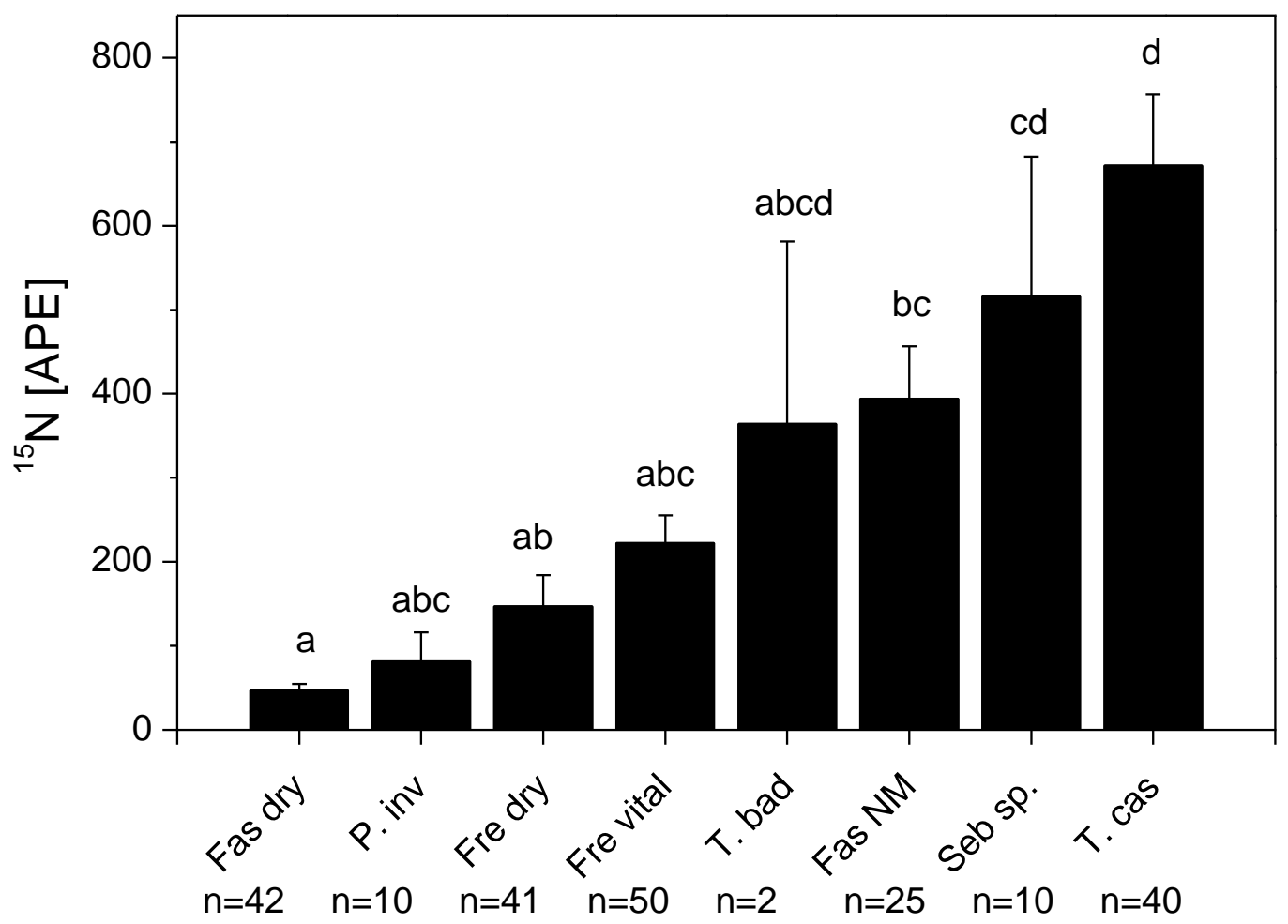

Figure 3.3: ${ }^{15} \mathrm{~N}$ signatures of dry root tips (dry), of ash (Fre) and beech (Fas), vital root tips of ash (vital), non-mycorrhizal root tips (NM) of beech and in ectomycorrhizal species Paxillus involutus (P. inv), Tomentella castanea (T. cas), Sebacina sp. (Seb sp) and Tomentella badia (T. bad). Data indicates means ( $\pm \mathrm{SE}$ ). Letters indicate significant differences with $\mathrm{P} \leq 0.05$. Tukeys HD test following one way ANOVA.

The most abundant EM species Tomentella castanea (68 $\pm 3 \%$ colonized root tips) and Sebacina sp. $\left(19 \pm 3 \%\right.$ colonized root tips) were highly enriched with ${ }^{15} \mathrm{~N}$. In contrast, the ${ }^{15} \mathrm{~N}$ label of Paxillus involutus remained low ( $4 \pm 1 \%$ colonized root tips). Its ${ }^{15} \mathrm{~N}$ signature was similar to non-mycorrhizal root tips and dry beech roots. This result demonstrates that whereas other EM sepcies accumulated $\mathrm{N}$ effectively, $P$. involutus barely accumulated nitrogen. 
Despite the differences between ${ }^{15} \mathrm{~N}$ singatures of EM species, total $\mathrm{N}$ contents of EM species were relatively similar (Fig. 3.4). This result suggests that the higher ${ }^{15} \mathrm{~N}$ signatures found in Tomentella spp. and Sebacina sp. did not result from a generally higher $\mathrm{N}$ content of fungal structures.

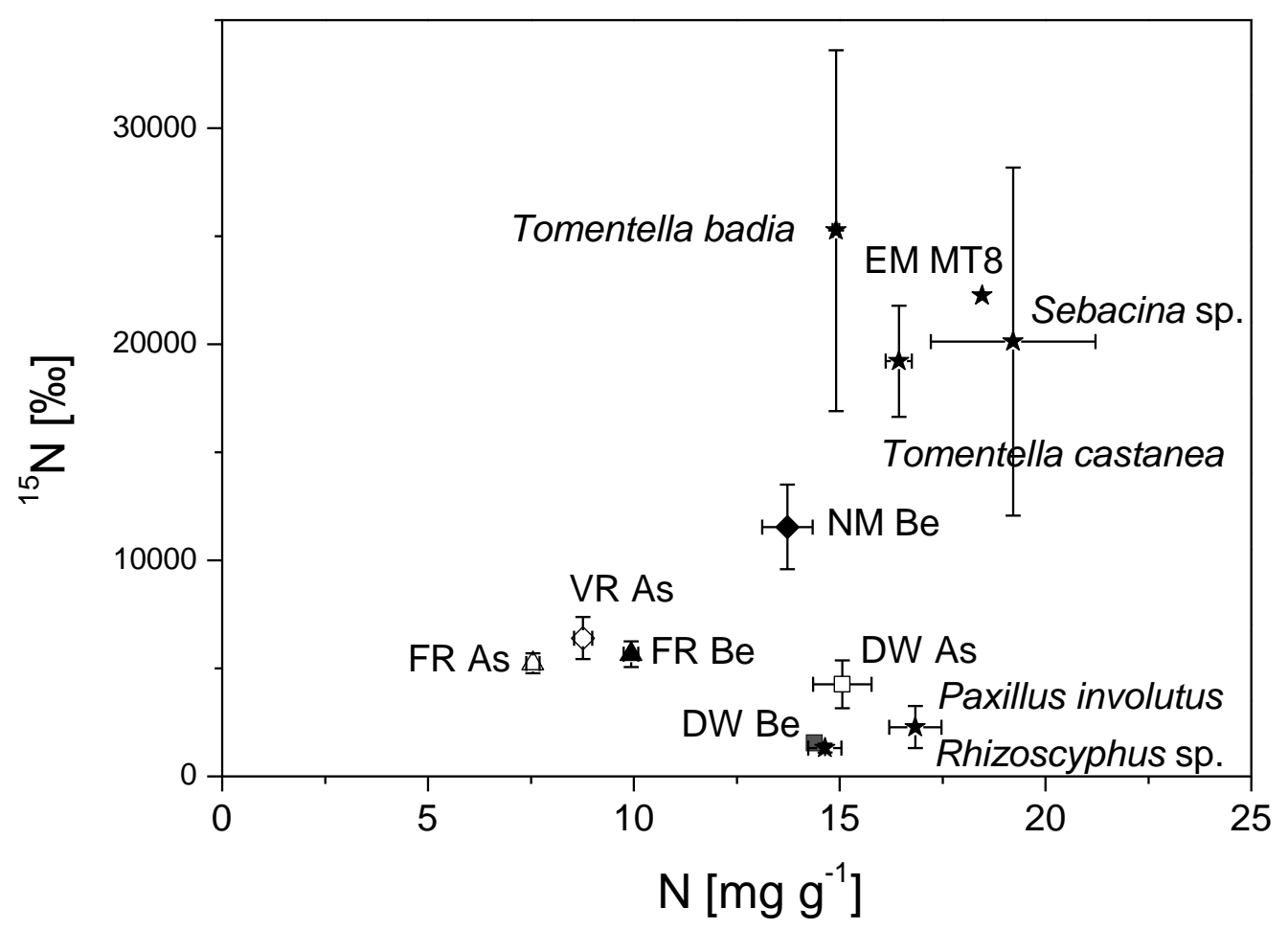

Figure 3.4: The relationship of ${ }^{15} \mathrm{~N}$ accumulation and total $\mathrm{N}$ concentration in ash (open symbols) and beech (filled symbols) fine roots (triangles), non-mycorrhizal root tips of beech (square), vital root tips of ash (square), dry root tips (rectangle) and root tips colonized with different EM species (stars).

\subsubsection{Relationship of ${ }^{15} \mathrm{~N}$ in mycorrhizal root tips and total fine root ${ }^{15} \mathrm{~N}$}

In order to investigate whether high ${ }^{15} \mathrm{~N}$ accumulation in mycorrhizal root tips resulted in an increased allocation of ${ }^{15} \mathrm{~N}$ into fine roots, we determined the relationship between the ${ }^{15} \mathrm{~N}$ signatures in both plant fractions. 
We found a low positive relationship of ${ }^{15} \mathrm{~N}$ signatures of EM root tips and mean fine root ${ }^{15} \mathrm{~N}$ signatures, but no correlation between non-mycorrhizal root tips and fine root ${ }^{15} \mathrm{~N}$ signatures (Fig. 3.5). These results indicate that mycorrhizal root tips might be more important for plant $\mathrm{N}$ uptake than non-mycorrhizal root tips.

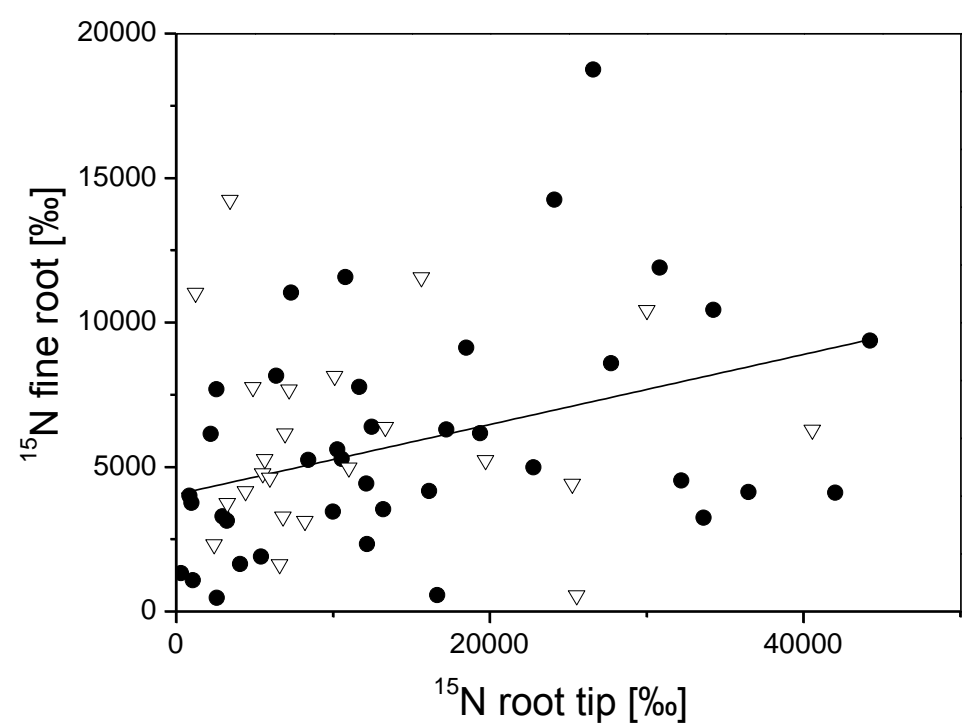

\begin{tabular}{lccc}
\hline $\begin{array}{l}\text { Plant } \\
\text { fraction }\end{array}$ & $y$ & $P$ & $R^{2}$ \\
\hline EM root tip & $y=4040+0.121 x$ & 0.017 & 0.121 \\
NM root tip & $y=-6010-0.001 x$ & 0.988 & -0.048
\end{tabular}

Figure 3.5: Relationship between recently accumulated ${ }^{15} \mathrm{~N}$ in fine roots and in EM fine root tips (filled dots, filled line) or NM root tips (open triangle).

\subsubsection{Relationship of ${ }^{15} \mathrm{~N}$ signatures in fine roots and leaves}

Subsequently we investigated whether a higher fine root ${ }^{15} \mathrm{~N}$ was related with an increased $\mathrm{N}$ accumulation in leaves. There was a positive relationship between ${ }^{15} \mathrm{~N}$ signatures of fine roots and leaves, with an exception of ash in mixture (Fig. 3.6 A, B). This result suggests that a higher ${ }^{15} \mathrm{~N}$ accumulation in fine roots might enhance the transport of $\mathrm{N}$ to leaves. In addition, partitioning of ${ }^{15} \mathrm{~N}$ in tissues of ash changed in the presence of beech. 


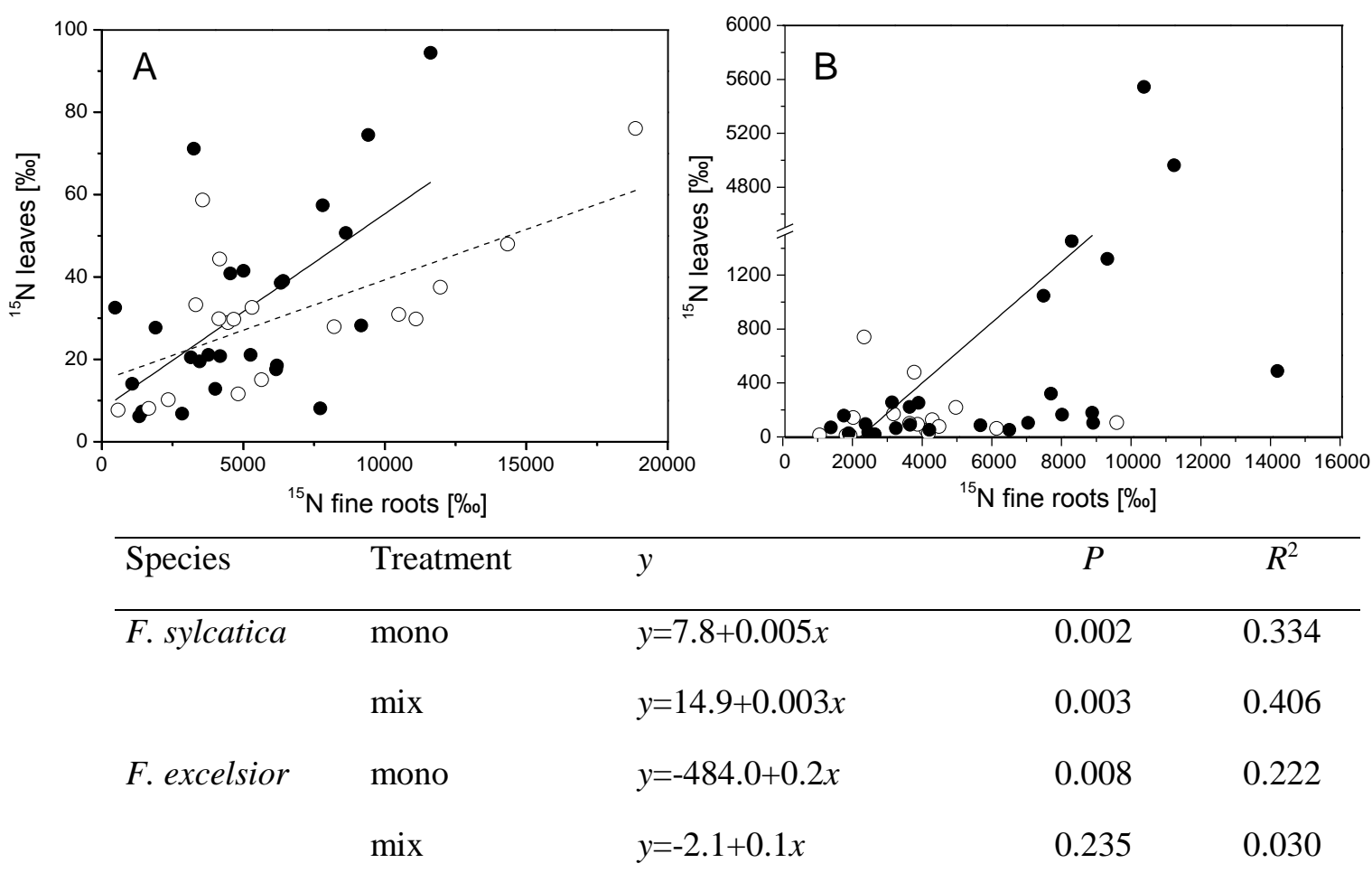

Figure 3.6: Relationship between recently accumulated ${ }^{15} \mathrm{~N}$ in fine roots and leaves of beech (A) and ash (B) grown in monoculture (filled dots, line) and mixture (open dots, dotted line).

\subsubsection{Short-term ${ }^{15} \mathrm{~N}$ and ${ }^{33} \mathrm{P}$ supply in mycorrhizal and $\mathrm{NM}$ root tips}

Because EM species with high ${ }^{33} \mathrm{P}$ accumulation were identified earlier (Chapter 2), we investigated whether high ${ }^{33} \mathrm{P}$ accumulation in these EM species was related with a high nitrogen accumulation. Because no significant differences were found between EM species from monocultures and mixtures, the EM samples from beech monocultures and mixtures were pooled together. The EM species could roughly been divided to three groups (Fig. 3.7).

The first group contains EM species T. castanea, . badia $(\mathrm{n}=2)$ and an unknown EM species MT8 ( $\mathrm{n}=1)$, which had relative high accumulations of both recently acquired phosphorus ( $\left.{ }^{33} \mathrm{P}\right)$ and ${ }^{15} \mathrm{~N}$. The second group included species P. involutus and Rhizoscyphus sp., which do not accumulate significantly more ${ }^{33} \mathrm{P}$ and ${ }^{15} \mathrm{~N}$ than vital or dry root tips. Thus, these species can be supposed to be relatively inactive for $\mathrm{N}$ and $\mathrm{P}$ uptake. The third group includes only one species, Sebacina sp. that had a relative high ${ }^{15} \mathrm{~N}$ accumulation, bur rather $\operatorname{low}{ }^{33} \mathrm{P}$ accumulation. These results indicate taxon related traits for $\mathrm{N}$ and $\mathrm{P}$ uptake within $\mathrm{EM}$ species. 


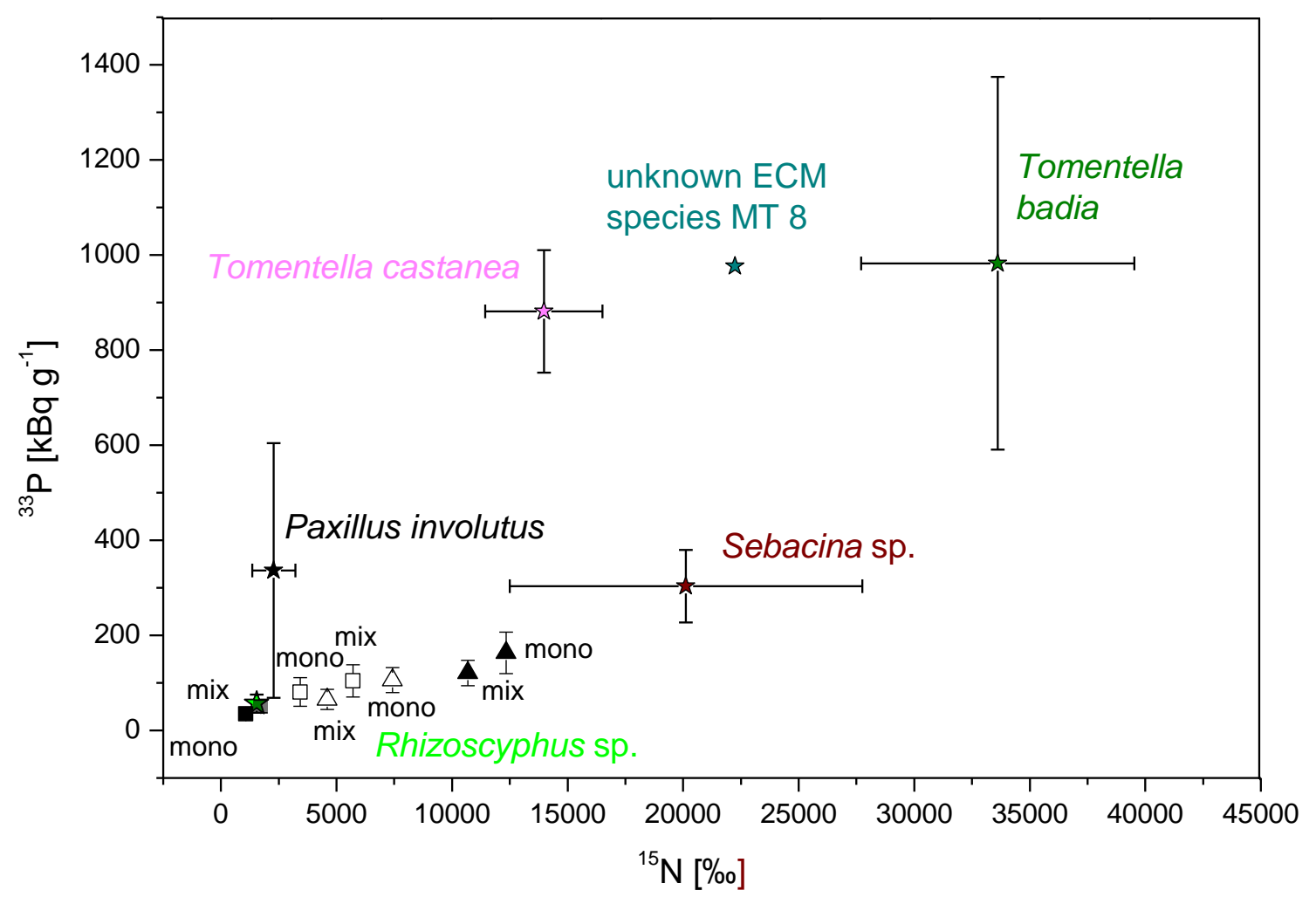

Figure 3.7: ${ }^{33} \mathrm{P}$ concentration $\left(\mathrm{kBq} \mathrm{g}^{-1}\right)$ and ${ }^{15} \mathrm{~N}$ signatures $(\delta \%$ in ash (open symbols) and beech (filled symbols) root tips. Different symbols represent different fine root fractions: Dry root tips (squares), vital root tips of ash (open triangles), non-mycorrhizal root tips of beech (filled triangles) and beech root tips colonized with different EM species (stars). Root tips were divided in roots from monocultures (mono) and mixtures (mix), with an exception of EM root tips. Data indicateds means $( \pm \mathrm{SE})$.

$\mathrm{N}$ and $\mathrm{P}$ accumulations of non mycorrhizal beech fine root tips and with vital, mycorrhizal ash fine root tips decreased in mixture. However, the difference between N/P ratios of monoculture and mixture were higher in non-mycorrhizal root tips of beech (difference, 12.7) than in root tips of ash (difference, 0.2). These results indicate that in mixture with ash, nonmycorrhizal beech root tips shift to $\mathrm{P}$ deficiency, whereas $\mathrm{N}$ and $\mathrm{P}$ supply of vital ash root tips was unaltered by the species identity of the neighbouring tree.

\subsubsection{Comparison of long-term and short-term $N$ and $P$ relations of fine roots and leaves}

The $\mathrm{N}$ and $\mathrm{P}$ accumulation in $\mathrm{EM}$ root tips might influence the relationship of $\mathrm{N}$ and $\mathrm{P}$ accumulation in other plant tissues. As an index of long-term $\mathrm{N}$ and $\mathrm{P}$ balance of the tree 
species, N/P ratios of plant tissues were compared (Tab. 3.3). Subsequently the N/P ratios were compared with short-term ${ }^{15} \mathrm{~N}$ and ${ }^{33} \mathrm{P}$ nutrition (Fig. $3.8 \mathrm{~A}, \mathrm{~B}$ ).

$\mathrm{N} / \mathrm{P}$ ratios of beech leaves were 16.1 in monoculture and 15.6 in mixture. These ratios suggest normal to optimal N/P balance of beech (Tab. 3.3). In contrast, leaf N/P ratios of ash were lower than 14 (mono: 11.5, mix: 12.4) indicated that ash was relatively more limited by $\mathrm{N}$ than by $\mathrm{P}$.

Table 3.3: Balanced leaf N/P ratios of beech and ash based on leaf nitrogen and phosphorus threshold values suggested by Mellert \& Göttlein (2012) and Kopinga \& van den Burg (1995)

\begin{tabular}{ccccccc}
\hline \multirow{3}{*}{ Species } & $\begin{array}{c}\text { optimal } \\
\text { leaf N } \\
\mathrm{mg} \mathrm{g}^{-1}\end{array}$ & $\begin{array}{c}\text { optimal } \\
\text { leaf } \mathrm{P} \\
\mathrm{mg} \mathrm{g}^{-1}\end{array}$ & $\begin{array}{c}\text { relative } \\
\mathrm{N} \\
\text { deficiency }\end{array}$ & $\begin{array}{c}\text { optimal } \\
\mathrm{N} / \mathrm{P} \\
\text { ratio }\end{array}$ & $\begin{array}{c}\text { relative } \\
\mathrm{P} \\
\text { deficiency }\end{array}$ & Reference \\
\hline F. sylvatica & $19-23$ & $1.2-1.9$ & $<10$ & $10-19$ & $>19$ & $\begin{array}{c}\text { Mellert \& Göttlein (2012) } \\
\text { F. excelsior }\end{array}$ \\
$223-28$ & $1.4-1.6$ & $<14$ & $14-20$ & $>20$ & $\begin{array}{c}\text { Kopinga \& van den Burg } \\
(1995)\end{array}$ \\
\hline
\end{tabular}

Total $\mathrm{N}$ and $\mathrm{P}$ concentrations of ash leaves decreased in mixture (Fig. $3.8 \mathrm{~A}$ ). In addition, the short-term $\mathrm{N}$ and $\mathrm{P}$ accumulation indicates that the nutrient allocation to leaves was affected by the presence of beech (Fig. $3.8 \mathrm{~B}$ ).
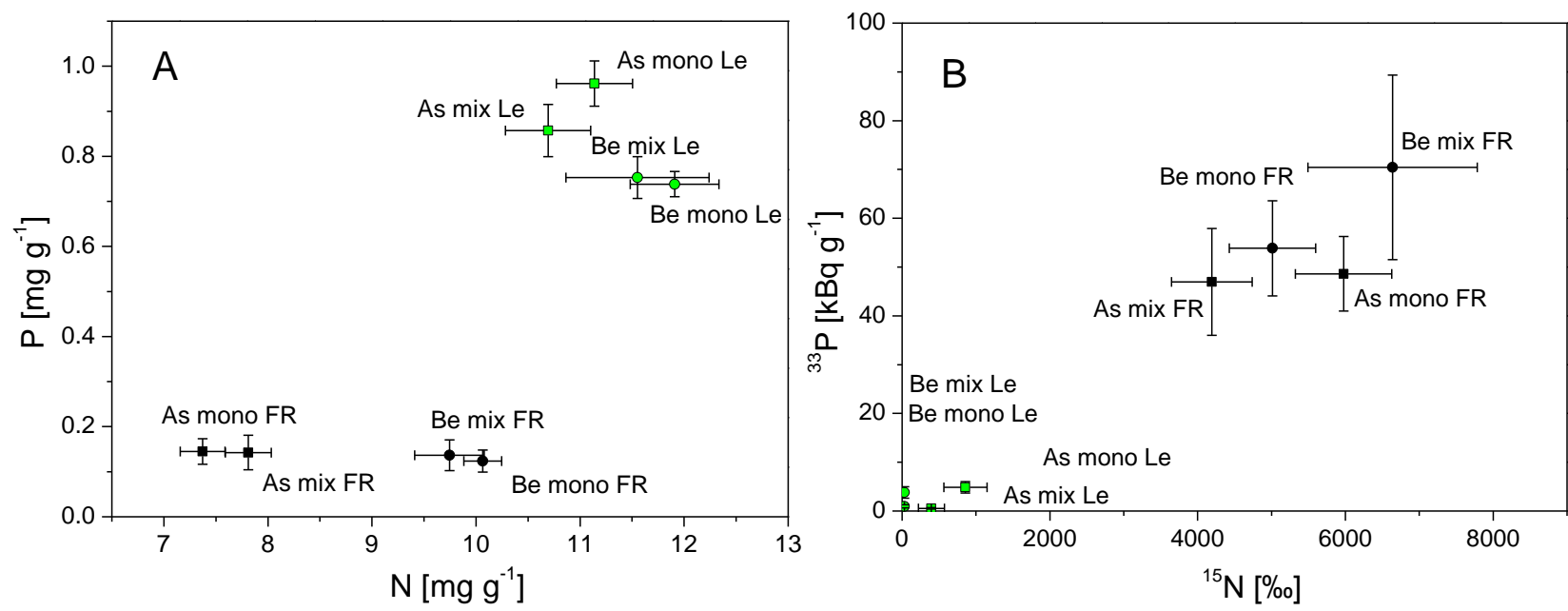

Figure 3.8: Long-term $\mathrm{N}$ and $\mathrm{P}$ supply (A), and short-term ${ }^{15} \mathrm{~N}$ and ${ }^{33} \mathrm{P}$ supply (B) in leaves (Le) and fine roots (FR) of beech (Be) and ash (As) grown in monocultures (mono) and twospecies mixtures (mix).

In fact, the difference value of leaf ${ }^{15} \mathrm{~N} /{ }^{33} \mathrm{P}$ ratios in mixture and monoculture was 22 times higher in ash than in beech. Fine root ${ }^{15} \mathrm{~N}$ and ${ }^{33} \mathrm{P}$ signatures of ash indicate that in the presence of beech $\mathrm{N}$ deficiency tended to increase more than P deficiency (Fig. 10B). In contrast, the growth in mixture with ash increased both ${ }^{15} \mathrm{~N}$ and ${ }^{33} \mathrm{P}$ accumulation of beech fine roots. 


\subsection{Discussion}

\subsubsection{Nitrogen uptake of beech and ash in heterospecific and conspecific pairs}

In accordance to our first hypothesis, the $\mathrm{N}$ deficiency of ash increased in the presence of beech. This was true although ash had a higher fine root biomass than beech. Experimental data and field surveys show that root biomass of ash tends to predominate in ash-beech mixtures (Jacob et al. 2012, Rust \& Savill 2000). The results of the present study demonstrate that a higher root biomass of ash does not necessary result in a competitive advantage for $\mathrm{N}$ acquisition. In fact, beech was capable to compete with ash for N, presumably due to its EM association. $\mathrm{N}$ uptake of beech was, contrary to expected, unaffected by species identity of the neighbouring tree.

${ }^{15} \mathrm{~N}$ in fine roots and leaves tended to have a positive relationship. This result indicates that higher $\mathrm{N}$ uptake results in an increased leaf $\mathrm{N}$ accumulation. Only exception was ash in conspecific mixture. At eighth labelling day, leaf ${ }^{15} \mathrm{~N}$ signatures of ash decreased in mixture. In contrast, ${ }^{15} \mathrm{~N}$ accumulation increased in fine roots. These results might indicate that over the time $\mathrm{N}$ uptake of ash decreased in the presence of beech. Since the uptake kinetics was not measured in this study, this is only a speculation. The conclusions of van der Heijden et al. (200I) support our suggestion. Van der Heijden et al. (2001) demonstrated that in nutrient poor conditions, nutrient uptake of Salix repens increased faster in plants inoculated with AM than in plants with EM (van der Heijden et al. 2001). However, in long term plants benefitted more from EM association (van der Heijden et al. 2001). This long-term beneft of EM association may partially explain the well-known dominance of beech in mixed forests from the middle of the biostatic phase of forest development (Emborg 1998).

Total leaf $\mathrm{N}$ concentration of ash was higher than that of beech. Ash also accumulated more ${ }^{15} \mathrm{~N}$ in leaves than beech. These differences occurred irrespective to the growth in monoculture or in two species mixture, and can therefore be considered as taxon related characteristics. The higher $\mathrm{N}$ accumulation in leaves might result from the reported higher $\mathrm{N}$ uptake rate of ash compared with beech (Schulz et al. 2011). It has been suggested that high nutrient uptake kinetics might not be a competitive advantage in a nutrient depleted ecosystem (Aerts 1999). High nutrient content of leafs and high nutrient uptake rates are presumably 
related to adaptation to nutrient rich ecosystems (Aerts 1999, Reich et al. 2003). Therefore, we suggest that ash is less adapted to nutrient depleted conditions than beech.

According to our knowledge, this was the first time that the N/P ratios of two competing tree species with different mycorrhizal types were investigated experimentally. N/P ratios reflect species specific differences and intraspecific responses to N and P supply (Güsewell 2004). Leaf N/P ratios demonstrate that contrary to ash, beech was able to maintain a balanced leaf $\mathrm{N} / \mathrm{P}$ ratio in nutrient limited conditions. This might indicate that beech used $\mathrm{N}$ and $\mathrm{P}$ resources more economical than ash. N/P ratios (Fig. 11A) and relationship of short-term accumulation of ${ }^{15} \mathrm{~N}$ and ${ }^{33} \mathrm{P}$ by ash suggest that ash was generally more limited by $\mathrm{N}$ than by $\mathrm{P}$. However, both $\mathrm{N}$ and $\mathrm{P}$ deficiency of ash increased in mixture with beech. These results indicate that no clear niche differentiation between ash and beech occurred. Since tree interspecific interactions might shift with stand age (Cavard et al. 2011), adult trees in field could respond differently in comparable soil conditions.

\subsubsection{The role of EM species in plant $N$ and $P$ uptake}

EM association enhanced remarkably beech $\mathrm{N}$ and $\mathrm{P}$ supply. The comparison of N/P ratios of NM beech root tips in heterospecific and conspecific mixtures demonstrated that in the presence of ash non-mycorrhizal beech fine root tips shift to $\mathrm{P}$ deficiency. These results suggest that when the mycorrhizal colonization of beech decreases, it shifts to P deficiency. These results support the theory suggested by (Aerts 2002) that the interspecific competition with AM associated plant drives EM plant in non-mycorrhizal stage to P deficiency. In other words: the outcome of plant competition for $\mathrm{N}$ and $\mathrm{P}$ is driven by their mycorrhizal association.

The differences in $\mathrm{N}$ accumulation between EM species were species specific. EM with highest relative abundances; Tomentella spp., and Sebacina sp. had the highest ${ }^{15} \mathrm{~N}$ signatures. Tomentella species are frequently found in EM root tips and in soil (Danielsen et al. 2012, Horton \& Bruns 2001, Kjøller 2006, Pena et al. 2010). The reason for the dominance of Tomentella species is not known, but they are demonstrated as good competitors in root colonisation (Kennedy et al. 2007), which might have important ecological functions, such as efficient nutrient acquisition in N limited conditions (Horton \& Bruns 2001, Lilleskov et al. 2002).

In contrast to the most abundant EM fungi in our experiment, $P$. involutus barely accumulated ${ }^{15} \mathrm{~N}$. This was surprising, since it is well known species from $\mathrm{N}$ uptake experiments 
(Arnebrant 1994, Kytöviita 2005, Kytöviita et al. 2001, Morel et al. 2006). We assume that the growth conditions might have affected nutrient uptake efficiency of $P$. involutus. This is supported by a survey of EM species abundance in forest sites with differing gradients of $\mathrm{N}$ deposition (Lilleskov et al. 2002). Dark mantled Tomentella species, similar to those abundant in our experiment, were suggested to be adapted to $\mathrm{N}$ uptake in N-poor soils; whereas P. involutus was suggested to be specialized to high $\mathrm{N}$ conditions (Lilleskov et al. 2002).

Consistent to our second hypothesis, species that were identified as high accumulative for $\mathrm{P}$ had often high accumulation of N (Tomentella spp. and unknown EM MT8). The second group of EM species (Paxillus involutus and Rhizoscyphus sp) had similar N and P ratios than non-mycorrhizal and dead fine root tips. These EM species did presumably not actively accumulate $\mathrm{N}$ or $\mathrm{P}$. As a third variation, Sebacina $\mathrm{sp}$. had a high $\mathrm{N}$ and an inter-mediate $\mathrm{P}$ accumulation. These differences in $\mathrm{N}$ and $\mathrm{P}$ acquisition suggest functional diversity of $\mathrm{EM}$ species. Nygren et al. (2008) and Nygren and Rosling (2009) showed that although many EM species share similar pools of genes for nitrate reductase (nar) and phosphomonoesterases, the growth of EM species differ significantly on supplied $\mathrm{N}$ and $\mathrm{P}$ sources. The authors infered continuously distributed traits to use different nutrient sources among EM species. Our results support this hypothesis. 


\subsection{Conclusions}

We investigated $\mathrm{N}$ and $\mathrm{P}$ acquisition in beech and ash in nutrient limited conditions with emphasis on roles of different mycorrhizal species on plant $\mathrm{N}$ and $\mathrm{P}$ acquisition.

Both tree species related effects on $\mathrm{N}$ accumulation and indications of interspecific competition for $\mathrm{N}$ were found. The differences in total $\mathrm{N}$ contents of fine roots, as well as the transport of recently acquired $\mathrm{N}$ to leaves were tree species related.

The shift in N/P relation of ash fine roots and leaves indicated that $\mathrm{N}$ and $\mathrm{P}$ deficiency of ash increased in mixture with beech. Despite of long-term nutrient limitation, beech leaf N/P ratios remained balanced.

These results are particularly important, since they indicate that beech is better adapted to nutrient limited conditions than ash. We believe that this might be an important aspect to consider by establishing mixed forests stands with beech and ash saplings on nutrient limited sites.

The $\mathrm{N}$ and $\mathrm{P}$ relations differed greatly within $\mathrm{EM}$ species, indicating taxon related traits for $\mathrm{N}$ and $\mathrm{P}$ uptake. These results suggest that the species composition of root colonizing fungi is of great importance for nutrient acquisition of the host plant.

In conclusion, competition, rather than facilitation, for $\mathrm{N}$ and $\mathrm{P}$ occurred between beech and ash saplings in mixture. EM fungi contributed significantly to $\mathrm{N}$ and $\mathrm{P}$ acquisition of beech. 


\subsection{References}

Aerts, R., (2002), 'The role of various types of mycorrhizal fungi in nutrient cycling and plant competition', In: van der Heijden, M. \& Sanders, I. E. (Eds) Mycorrhizal ecology (Ecological Studies: Analysis \& Synthesis), Springer, Berlin, 117-133.

Arnebrant, K. (1994), 'Nitrogen amendments reduce the growth of extramatrical ectomycorrhizal mycelium', Mycorrhiza 5, 7-15.

Brandes, B. (1999), 'Nährstofftransport durch das extramatrikale Myzel von Ektomykorrhizapilzen - Umfang und Einfluß auf die Ernährung der Fichte (Picea abies)', Culliverer Verlag, Göttingen, 1-88.

Cavard, X., Bergeron, Y., Chen, H. Y. H., Paré, D., Laganiére, J. \& Brassard, B. (2011), 'Competition and facilitation between tree species change with stand development', Oikos 120(11), 1683-1695.

Chalot, M., Blaudez, D. \& Brun, A. (2006), 'Ammonia: a candidate for nitrogen transfer at the mycorrhizal interface', Trends in Plant Science 11(6), 263-266.

Chalot, M. \& Brun, A. (1998), 'Physiology of organic nitrogen acquisition by ectomycorrhizal fungi and ectomycorrhizas', FEMS Microbiology Reviews 22(1), 21-44.

Colpaert, J. V., van Laere, A. \& van Assche, J. A. (1996), 'Carbon and nitrogen allocation in ectomycorrhizal and non-mycorrhizal Pinus sylvestris L. seedlings', Tree Physiology 16(9), 787-793.

Corrêa, A., Gurevitch, J., Martins-Loução, M. A. \& Cruz, C. (2012), 'C allocation to the fungus is not a cost to the plant in ectomycorrhizae', Oikos 121(3), 449-463.

Danielsen, L., Thürmer, A., Meinicke, P., Buée, M., Morin, E., Martin, F., Pilate, G., Daniel, R., Polle, A. \& Reich, M. (2012), 'Fungal soil communities in a young transgenic poplar plantation form a rich reservoir for fungal root communities', Ecology and Evolution 2(8), 1935-1948.

Ellenberg, H. \& Leuschner, C. (2010), Vegetation Mitteleuropas mit den Alpen, Ulmer Verlag, Stuttgart.

Emborg, J. (1998), 'Understorey light conditions and regeneration with respect to the structural dynamics of a near-natural temperate deciduous forest in Denmark', Forest Ecology and Management 106(2-3), 83-95.

Fellbaum, C. R., Gachomo, E. W., Beesetty, Y., Choudhari, S., Strahan, G. D., Pfeffer, P. E., Kiers, E. T. \& Bücking, H. (2012), 'Carbon availability triggers fungal nitrogen uptake and transport in arbuscular mycorrhizal symbiosis', Proceedings of the National Academy of Sciences of the United States of America 109(7), 2666-2671. 
Finlay, R. D., H. Ek, Odham, G. \& Söderström, B. (1989), 'Uptake, translocation and assimilation of nitrogen from ${ }^{15} \mathrm{~N}$-labelled ammonium and nitrate sources by intact ectomycorrhizal systems of Fagus sylvatica infected with Paxillus involutus', New Phytologist 113, 47-55.

Govindarajulu, M., Pfeffer, P. E., Jin, H., Abubaker, J., Douds, D. D., Allen, J. W., Bücking, H., Lammers, P. J. \& Shachar-Hill, Y. (2005), 'Nitrogen transfer in the arbuscular mycorrhizal symbiosis', Nature 435(9).

Güsewell, S. (2004), 'N:P ratios in terrestrial plants: variation and functional significance', New Phytologist 164(2), 243-260.

Hawkins, H.-J., Johansen, A. \& George, E. (2000), 'Uptake and transport of organic and inorganic nitrogen by arbuscular mycorrhizal fungi', Plant and Soil 226, 275-285.

Hodge, A. \& Fitter, A. H. (2010), 'Substantial nitrogen acquisition by arbuscular mycorrhizal fungi from organic material has implications for $\mathrm{N}$ cycling', Proceedings of the National Academy of Sciences of the United States of America 107(31), 13754-13759.

Jacob, A., Hertel, D. \& Leuschner, C. (2012), 'On the significance of belowground overyielding in temperate mixed forests: separating species identity and species diversity effects', Oikos, In press, Online access 11 September 2012.

Jin, H., Pfeffer, P. E., Douds, D. D., Piotrowski, E., Lammers, P. J. \& Shachar-Hill, Y. (2005), 'The uptake, metabolism, transport and transfer of nitrogen in an arbuscular mycorrhizal symbiosis', New Phytologist 168(3), 687-696.

Kennedy, P. G., Bergemann, S. E., Hortal, L, S. \& Bruns, T. D. (2007), 'Determining the outcome of field-based competition between two Rhizopogon species using real-time PCR', Molecular Ecology 16(4), 881-890.

Kiers, E. T., Duhamel, M., Beesetty, Y., Mensah, J. A., Franken, O., Verbruggen, E., Fellbaum, C. R., Kowalchuk, G. A., Hart, M. M., Bago, A., Palmer, T. M., West, S. A., Vandenkoornhuyse, P., Jansa, J. \& Bücking, H. (2011), 'Reciprocal rewards stabilize cooperation in the mycorrhizal symbiosis', Science 333(6044), 880-882.

Kjøller, R. (2006), 'Disproportionate abundance between ectomycorrhizal root tips and their associated mycelia', FEMS Microbiology Ecology 58(2), 214-224.

Kopinga, J. \& van den Burg, J. (1995), 'Using soil and foliar analysis to diagnose the nutritional status of urban trees', Journal of Arboriculture 21(1), 17-24.

Kytöviita, M.-M. (2005), 'Asymmetric symbiont adaptation to arctic conditions could explain why high arctic plants are non-mycorrhizal', FEMS Microbiology Ecology 53(1), 27-32. 
Kytöviita, M.-M., Thiec, D. L. \& Dizengremel, P. (2001), 'Elevated $\mathrm{CO}_{2}$ and ozone reduce nitrogen acquisition by Pinus halepensis from its mycorrhizal symbiont', Plant Physiology 111(3), 305-312.

Lang, C. \& Polle, A. (2011), 'Ectomycorrhizal fungal diversity, tree diversity and root nutrient relations in a mixed Central European forest', Tree Physiology 31(5), 531- 538.

Lilleskov, E. A., Fahey, T. J., Horton, T. R. \& Lovett, G. M. (2002), 'Belowground ectomycorrhizal fungal community change over a nitrogen deposition gradient in Alaska', Ecology 83, 104-115.

Marmeisse, R., Guidot, A., Gay, G., Lambilliotte, R., Sentenac, H., Combier, J.-P., Melayah, D., Fraissinet-Tachet, L. \& Debaud, J. (2004), 'Hebeloma cylindrosporum a model species to study ectomycorrhizal symbiosis from gene to ecosystem', New Phytologist 163, 481-498.

Morel, M., Buée, M., Chalot, M. \& Brun, A. (2006), 'NADP-dependent glutamate dehydrogenase: a dispensable function in ectomycorrhizal fungi', New Phytologist 169(1), 179-189.

Nygren, C. M. R., Eberhardt, U., Karlsson, M., Parrent, J. L., Lindahl, B. D. \& Taylor, A. F. S. (2008), 'Growth on nitrate and occurrence of nitrate reductase-encoding genes in a phylogenetically diverse range of ectomycorrhizal fungi', New Phytologist 180(4), 875-889.

Nygren, C. M. R. \& Rosling, A. (2009), 'Localisation of phosphomonoesterase activity in ectomycorrhizal fungi grown on different phosphorus sources', Mycorrhiza 19(3), 197-204.

Pena, R., Offermann, C., Simon, J., Naumann, P.S., Gessler, A., Holst, J., Dannenmann, M., Mayer, H., Kögel-Knabner, I., Rennenberg, H. \& Polle, A. (2010), 'Girdling affects ectomycorrhizal fungal (EMF) diversity and reveals functional differences in EMF community composition in a beech forest', Applied and Environmental Microbiology 76(6), 1831-1841.

Pérez-Tienda, J., Valderas, A., Camañes, G., García-Agustín, P. \& Ferrol, N. (2012), 'Kinetics of $\mathrm{NH}_{4}^{+}$; uptake by the arbuscular mycorrhizal fungus Rhizophagus irregularis', Mycorrhiza 22, 485-491.

Reich, P. B., Wright, I. J., Cavender-Bares, J., Craine, J. M., Oleksyn, J., Westoby, K. M. \& Walters, M. B. (2003), 'The evolution of plant functional variation: traits, spectra, and strategies', International Journal of Plant Sciences 164(3), 143-164.

Rennenberg, H., Dannenmann, M., Gessler, A., Kreuzwieser, J., Simon, J. \& Papen, H. (2009), 'Nitrogen balance in forest soils: nutritional limitation of plants under climate change stresses', Plant Biology 11(1), 4-23. 
Rust, S. \& Savill, P. (2000), 'The root systems of Fraxinus excelsior and Fagus sylvatica and their competitive relationships', Forestry 73(5), 499-508.

Schulz, H., Härtling, S. \& Stange, C. F. (2011), 'Species-specific differences in nitrogen uptake and utilization by six European tree species', Journal of Plant Nutrition and Soil Science 174(1), 28-37.

Smith, S. E. \& Read, D. J. (2008), Mycorrhizal Symbiosis, $3^{\text {rd }}$ edn, Academic Press, London.

Stadler, J., Gebauer, G. \& Schulze, E.-D. (1993), 'The influence of ammonium on nitrate uptake and assimilation in 2-year-old ash and oak trees - a tracer-study with ${ }^{15} \mathrm{~N}$ ', Isotopenpraxis Isotopes in Environmental and Health Studies 29(1-2), 85-92.

Tobar, R., Azcón, R. \& Barea, J. M. (1994), 'Improved nitrogen uptake and transport from ${ }^{15} \mathrm{~N}$-labelled nitrate by external hyphae of arbuscular mycorrhiza under water-stressed conditions', New Phytologist 126(1), 119-122.

Team, R. D. C. (2008), R: A language and environment for statistical computing., R Foundation for Statistical Computing, Vienna, Austria. http://www.R-project.org. Access date: 28.11.2012.

van der Heijden, E. W. (2001), 'Differential benefits of arbuscular mycorrhizal and ectomycorrhizal infection of Salix repens', Mycorrhiza 10(4), 185-193. 


\title{
Chapter 4
}

\author{
ECTOMYCORRHIZA AS A LINK \\ BETWEEN TREES \\ (FAGUS SYLVATICA) AND \\ THE BELOWGROUND FOOD WEB
}




\subsection{Introduction}

Recently, there has been growing awareness of the relevance of ectomycorrhizal fungi (EM) to belowground food webs. Ectomycorrhiza play a key role in plant nutrient uptake and plant defence, but they also serve as an important channel of plant mediated carbon to soil food web (Pollierer et al. 2012). In temperate forests, ectomycorrhizal fungi contribute to $80 \%$ of the host plant nitrogen (van der Heijden et al. 2008). Up to $30 \%$ of the total photoassimilate carbon is transferred to the fungal symbiosis partner (Smith \& Read 1997) and partitioned to three different pools: fungal biomass, exudation and respiration. Well reported is the high EM biomass in forest soils. The fungal mycelium comprises up to $70 \mathrm{mg} \mathrm{g}^{-1}$ soil (Vinichuk \& Johanson 2003) and Wallander et al. (2001, 2004) estimated total amount of EM mycelium including EM mantles up to 700-900 kg.ha ${ }^{-1}$ (Wallander et al. 2004, Wallander et al. 2001), others suggest approximately $30 \%$ of the microbial biomass and $80 \%$ of the fungal biomass in boreal forest soils to be ectomycorrhizal mycelium (Högberg \& Högberg 2002, Wallander et al. 2003, Wallander et al. 2001).

The metabolic activities among ectomycorrhizal tips differ largely. (Jany et al. 2003) measured with a microradiorespirometry assay respiration rates between 7 and $34 \mathrm{nmol} \mathrm{O} \mathrm{g}^{-1} \mathrm{~s}^{-1}$ in ectomycorrhizal root tips of different EM species. High variability of respiration rates between single ectomycorrhizal root tips has also been found (Jany et al. 2003, Trocha et al. 2010).

Exudation is considered as an important component of EM's overall C budget (Fransson \& Johansson 2010, Godbold et al. 2006, Högberg \& Högberg 2002). Exudation serves the nutrient uptake by mineral weathering (Landeweert et al. 2001), mineralisation of organic polymers (Durall et al. 1994, Read \& Perez-Moreno 2003), and is also required for the nutrient uptake process, metal detoxification and antimicrobial defence (Bais et al. 2006). The range of produced substances differs between EM species. Exudates consist mainly of low molecular weight organic acids, saccharides, amino acids and peptides but ectomycorrhizal root tips also release fatty acids, polymeric carbohydrates and different enzymes into the rhizosphere (Courty et al. 2005, Gadd 2007). Hence, EM hyphae presumably contribute in a considerable manner to the nutrition of soil animals and carbon cycling (Bonkowski et al. 2009, Landeweert et al. 2001, Langley et al. 2006).

Despite the increasing interest on connecting mycorrhizal symbiosis with belowground ecosystem functions, our knowledge about the relationship of EM and soil animals is limited. 
Recent studies have shown that the number of soil animals depending on carbon from EM fungi has been underestimated (Pollierer et al. 2007, Pollierer et al. 2009). Spore findings of EM in guts of soil animals suggest that diverse species feed on EM and serve the spore dispersal of belowground fruiting EM (Lilleskov \& Bruns 2005). Feeding experiments with axenic fungal cultures have shown soil fauna species to feed selectively on fungi (Hiol et al. 1994, Scheu \& Simmerling 2004). However, due to the differences in EM metabolism in symbiotic stage and the large variety of EM species in natural communities (Lang et al. 2011) feeding choice experiments can hardly reflect natural behaviour of EM feeding soil animals.

${ }^{13} \mathrm{C}$ and ${ }^{15} \mathrm{~N}$ tracing is a useful method to investigate nutrient fluxes and trophic interactions. Feeding strategies and trophic relations of soil animals have been investigated by comparing both natural and experimentally enriched abundances of stable isotopes ${ }^{13} \mathrm{C}$ and ${ }^{15} \mathrm{~N}$ in soil food web (Högberg et al. 2010, Pollierer et al. 2009, Scheu \& Falca 2000, Wardle et al. 2011). Application of stable isotope tracers allows a time-integrated detection of trophic pathways for nutrients derived from specific sources. The majority of early fungal studies with stable isotopes was limited to measurements on aboveground fruit bodies (Gebauer \& Dietrich 1993, Gebauer \& Taylor 1999, Högberg et al. 1999). Meanwhile the focus of experiments is increasingly on belowground trophic interactions. Högberg et al. (2010) showed that ${ }^{13} \mathrm{C}$ levels of Collembola species increased within days after a $\mathrm{CO}_{2}$ labelling (Högberg et al. 2010). Pollierer et al. (2007) identified different diets of soil arthropods such as leaf litter, root derived and soil carbon respectively. Though recent research using stable tracers has shown plant recent photoassimilates as one of the most important carbon source of soil animals, it remains unclear if mycorrhizal structures were the primarly diet. Numerous soil animals are considered as fungivorous (Pollierer et al. 2007), often without paying attention as to whether these fungi are mycorrhizal or saprotrophic. Moreover, the majority of experiments have been performed in arbuscular mycorrhiza comprising grassland ecosystems (Graham 2001, Hempel et al. 2009, Hoffmann et al. 2009, Koricheva et al. 2009). Because of the vast importance of EM for plant fitness, better understanding of the trophic interactions of soil animals and EM is of great relevance. Since previous research has pointed out the ability of mycorrhizal fungi to interact with and influence a number of predator species of plant feeding species (Bonkowski et al. 2009, Hempel et al. 2009, Hoffmann et al. 2011) the predator arthropods with a trophic link to ectomycorrhizas are of special interest. 
The aim of this study was to determine carbon and nitrogen fluxes between beech trees (Fagus sylvatica), its mycorrhizal fungi and soil arthropods. We used ${ }^{13} \mathrm{C}$ enriched $\mathrm{CO}_{2}$ and ${ }^{15} \mathrm{~N}$ labeled $\mathrm{NO}_{3} \mathrm{NH}_{4}$ nutrient solution to label beech seedlings. Intact soil cores ensured vital beech plants and associated mycorrhiza as well as an undisturbed soil animal community. To analyse carbon and nitrogen allocation processes, we measured ${ }^{13} \mathrm{C}$ and ${ }^{15} \mathrm{~N}$ label in leaves, stem, fine roots, mycorrhizal root tips, in addition to fine roots directly above the mycorrhizal root tip and in soil animals.

We hypothetized that (a) EM-colonized root tips are strong sinks for both $\mathrm{C}$ and $\mathrm{N}$, (b) the accumulation of ${ }^{13} \mathrm{C}$ and ${ }^{15} \mathrm{~N}$ in root EM tips is directly related to the exchange of $\mathrm{C}$ and $\mathrm{N}$ with the attached root and (c) ectomycorrhiza are an attractive nutrient source for a number of soil arthropod species.

\subsection{Materials and Methods}

\subsubsection{Plant material and experimental setup}

The sampling sites were deciduous forest stands in two parts (Thiemsburg and Lindig) of National Park Hainich, Thuringia, Germany $\left(51^{\circ} 05^{\prime} 28^{\prime \prime} \mathrm{N}, 10^{\circ} 31^{\prime} 24^{\prime \prime} \mathrm{E}\right)$. The forest was unmanaged for at least four decades and is characterised by having a total annual precipitation of 600-670 mm and an annual mean temperature of 7.5-8.0 ${ }^{\circ} \mathrm{C}$ (Leuschner et al. 2009). Naturally regenerated seedlings of Fagus sylvatica with a height of approximately $40 \mathrm{~cm}$ were extracted within intact soil cores, transported to a greenhouse and placed in pots with diameter of $25 \mathrm{~cm}$, a height of $45 \mathrm{~cm}$ and a drainage

A total of nine trees were exposed to ${ }^{13} \mathrm{CO}_{2}$ enriched air $\left(1018 \pm 340 \mathrm{ppm},{ }^{13} \mathrm{CO}_{2}\right.$, EURISOTOP GmbH, Saarbrücken, Germany) for one growing season (24.04- 05.10.09) at an average temperature of $22.8{ }^{\circ} \mathrm{C}( \pm 2.8)$ and humidity of $71.8 \%( \pm 13)$. Contemporaneously, the plants were irrigated daily with a Hoagland-based nutrient solution containing $0.6 \mathrm{mM} \mathrm{CaCl} 2,0.4$ $\mathrm{mM} \mathrm{MgSO}_{4}, 0.01 \mathrm{mM} \mathrm{FeCl}_{3}, 0.4 \mathrm{mM} \mathrm{K}_{3} \mathrm{PO}_{4}, 1.8 \mu \mathrm{M} \mathrm{MnSO}_{4}, 0.064 \mu \mathrm{M} \mathrm{CuCl}, 0.15 \mu \mathrm{M}$ $\mathrm{ZnCl}_{2}, 0.1 \mu \mathrm{M} \mathrm{MoO}_{3}, 0.01 \mathrm{mM} \mathrm{H}_{3} \mathrm{BO}_{3}, 5 \mathrm{mM} \mathrm{NO}_{3} \mathrm{NH}_{4}$ and $0.1 \mathrm{mM}^{15} \mathrm{NO}_{3}{ }^{15} \mathrm{NH}_{4}$ (Euriso-top, Saint-Aubin, Essonne, France). The soil moisture was kept at 30\% during the experiment. 


\subsubsection{Plant harvest and soil collection}

At the end of the experimental treatment (05.10.09), leaf and aboveground plant mass were weighted. The soil columns were divided into two depth fractions: $0-5 \mathrm{~cm}$ corresponding to the $\mathrm{A}_{1}$ horizon, and 5-21 $\mathrm{cm}$ corresponding to the top of the $\mathrm{A}_{2}$ horizon. Soil fauna were trapped in the litter and upper soil layers. The roots in the lower soil layer (below $5 \mathrm{~cm}$ depth) were immediately washed with hand warm tap water, divided into coarse (> $2 \mathrm{~mm})$ and fine root fractions and weighed. After removal of trapped animals the roots in the upper horizon were also washed and weighed. Both root fractions were stored at $4{ }^{\circ} \mathrm{C}$ in moist tissue paper in plastic bags for mycorrhizal analysis. Leaf morphology and area were analysed from flatbed scanner images usingWinFolia 2005a,b (Régent Instruments Inc., Québec, QC, Canada). Subsequently, the plant material was dried for 4 days at $70{ }^{\circ} \mathrm{C}$ and the dry masses of all plant fractions were recorded. Soil and leaf litter were also collected, dried and used for further analyses.

\subsubsection{Soil animal harvest and identification}

Soil fauna were collected from the entire upper soil layer by using a heat gradient extractor (Kempson 1963), driven out into glycol and stored in 70\% EtOH. Animals were counted and sorted to group level. Lumbricids, Araneidae, Isopoda, Chilopoda (Strigamia accuminata, Lithobiidae and Geophilidae), Diplopoda, Oribatida and Collembolans were determined to species level.

\subsubsection{Ectomycorrhizal identification and quantification}

Fine roots of nine beech trees were examined with a stereomicroscope (Leica M205 FA, Leica Microsystems, Wetzlar, Germany). To determine EM colonization of the root tips, five fine root fragments were randomly selected in each sample and 500 vital root tips were counted. The percentage of EM colonization was calculated as: $\mathrm{EM}$ root tips/(EM root tips + non mycorrhizal vital root tips)x100.

Mycorrhizal roots tips were classified using the previously described (Druebert et al. 2009, Lang et al. 2011). morphotyping system developed by Agerer (1987-2006). The abundance of each morphotype in each subsample was recorded, the morphotypes photographed (Leica DFC420 C, Leica Microsystems, Wetzlar, Germany) and collected for chemical and molecular analyses. 


\subsubsection{Molecular identification of the EM species}

DNA was extracted from 10-40 mycorrhizal root tips per sample using innuPREP Plant DNA Kit (Analytik Jena AG, AJ Innuscreen $\mathrm{GmbH}$, Jena, Germany) according to the manufacturer's instructions, with the exception that lysis buffer and protease were added to the sample before the homogenisation with a push rod. DNA was resuspended in $100 \mu \mathrm{l}$ elution solution. A polymerase chain reaction (PCR) product of the complete region of the internal transcribed spacer (ITS) region was amplified with the primer pair ITS1f $5^{\prime}-$ CTTGGTCATTTAGAGGAAGTAA-3’and ITS4 5'- TCCTCCGCTTATTGATATGC -3' (White et al., 1990; Gardes and Bruns, 1993). The total volume of the PCR reaction was 25 $\mu 1$, containing $10 \times$ PCR buffer with $\left(\mathrm{NH}_{4}\right)_{2} \mathrm{SO}_{4}$ (Fermentas, St-Leon-Rot, Germany), $2 \mathrm{mM}$ $\mathrm{MgCl}_{2}, 200 \mu \mathrm{M}$ of each dNTP, $0.5 \mu \mathrm{M}$ each primer and $0.5 \mathrm{U}$ Taq-polymerase (Fermentas, St-Leon-Rot, Germany). The PCR was performed in a Mastercycler Gradient (Eppendorf, Hamburg, Germany) with the following settings: initial denaturation at $95{ }^{\circ} \mathrm{C}$ for $60 \mathrm{~s}$, denaturation at $94^{\circ} \mathrm{C}$ for $30 \mathrm{~s}$, annealing at $55^{\circ} \mathrm{C}$ for $30 \mathrm{~s}$ and elongation at $72{ }^{\circ} \mathrm{C}$ for $60 \mathrm{~s}$. This was repeated for 35 cycles before the final elongation at $72{ }^{\circ} \mathrm{C}$ for $10 \mathrm{~min}$. If the subsequent gel analysis revealed more than one PCR product the PCR products were cloned in E. coli TOP19 (Invitrogen, Carlsbad, California, USA).

The ligation and transformation of the ITS-PCR products was done with a pGEM ${ }^{\circledR}-\mathrm{T}$ and pGEM®-T easy Vector system kit following the manufacter's instructions (Promega Corporation, Madison, USA), with the exception that the litigation product was incubated $1 \mathrm{~h}$ at $16^{\circ} \mathrm{C}$. For the transformation Luria Bertani-medium $(10 \mathrm{~g} / \mathrm{l}$ tryptone, $5 \mathrm{~g} / \mathrm{l}$ yeast extract, $10 \mathrm{~g} / \mathrm{l} \mathrm{NaCl}, 15 \mathrm{~g} / \mathrm{l}$ agar and 11 demineralised $\mathrm{H}_{2} \mathrm{O}$ ) with $100 \mu \mathrm{g} / \mathrm{ml}$ Ampicillin, $200 \mathrm{mg} / \mathrm{ml}$ IPTG, and $20 \mathrm{mg} / \mathrm{ml} \mathrm{X-Gal} \mathrm{in} \mathrm{DMF} \mathrm{was} \mathrm{prepared.} \mathrm{The} \mathrm{PCR} \mathrm{products} \mathrm{were} \mathrm{sequenced} \mathrm{at} \mathrm{the}$ Department of Forest Genetics and Forest Tree Breeding, University of Göttingen with an ABI Prism 3100 Genetic Analyzer (Applied Biosystems, Foster City, USA). The sequences were edited with Staden Package (4.10, http://staden.sourceforge.net) and multiple sequence alignments were made with Clustal W (http://align.genome.jp). For the fungal species identification, sequences were compared with NCBI Genbank (www.ncbi.nlm.nih.gov) and UNITE (Kõljalg et al. 2005) databases. If the score was higher than 700 bits and the homology more than $97 \%$ the species suggested in gene bank, preferably UNITE was used. If the score was 600-700, homology 95-97\% and both databases suggested the same genus, the species was recorded as an unknown species of the suggested genus. The sequences with 
lower scores or a database sequence identity limited to family level were recorded on the basis of the results of a phylogenetic analysis or remained as unknown mycorrhizal species.

A phylogenetic tree of the EM species based on an alignment of ITS 1 and 2 and $2.5 \mathrm{~S}$ sequences with a total alignment length of 659 bases was constructed using SeaView (4.2.12, http://pbil.univ-lyon1.fr/software/seaview.html) program (Gouy et al. 2010). A Maximum Likelihood phylogram using GTR model aLRT was created with the following settings: invariable sites were ignored, optimized across site rate variation with 4 rate categories, NNI tree searching operation, BioN starting tree option, optimized tree topology and 5 random sites. Bootstrap values were calculated with 100 replicates.

\subsubsection{Chemical analysis: ${ }^{13} \mathrm{C}$ and ${ }^{15} \mathrm{~N}$ labeling}

Dry plant tissues (leaf, wood, coarse root, fine root) as well as aliquots of soil from upper soil layer and leaf litter were milled with a ball mill (Type MM 2, Retsch, Haan, Germany), dried for another $24 \mathrm{~h}$ at $70^{\circ} \mathrm{C}$ and kept in an exicator. Aliquots of the samples were weighed into tin capsules and the of ${ }^{15} \mathrm{~N} /{ }^{14} \mathrm{~N}$ and ${ }^{13} \mathrm{C} /{ }^{12} \mathrm{C}$ were analyzed with an isotope ratio mass spectrometer IRMS (Delta C, Finnigan MAT, Bremen, Germany) at the Centre for Stable Isotope Research and Analysis, University of Göttingen. All mycorrhizal species and 3-10 $\mathrm{mm}$ long fine root sections next to the mycorrhizal mantle, directly connected with a given EM were analyzed after weighting ca $1 \mathrm{mg}$ directly into tin capsules.

The isotopic composition of plant tissues, mycorrhiza, soil animals, soil and above ground litter was calculated as

$\delta_{\text {sample } i}[\% 0]=\frac{R_{\text {sample } i}-R_{\text {standard }}}{R_{\text {standard }}} * 1000$

where $R_{\text {sample } i}$ and $R_{\text {standard }}$ represent the ${ }^{13} \mathrm{C} /{ }^{12} \mathrm{C}$ and ${ }^{15} \mathrm{~N} /{ }^{14} \mathrm{~N}$ ratios of the sample $i$ and standards. Results are shown in the $\delta$ notation in \%o relative to the international standard Vienna Pee Dee belemnite (V-PDB) and 28/29 ratio.

We used the isotopic label of the fine roots as a reference to remove the background variability of the ${ }^{13} \mathrm{C}$ label.

$\Delta_{\text {sample } i}[\% 0]=\delta_{\text {sample } i}-\delta_{\text {fine roots } i}$

Additionally the atom fraction expressed as percentages (atom \%) was used to analyse the ${ }^{15} \mathrm{~N}$ and ${ }^{13} \mathrm{C}$ levels of plant and mycorrhizal tissues. 


\subsubsection{Statistical analysis}

The statistical computing was carried out with $\mathrm{R}$ software v.2.10.0 (The R Foundation for Statistical Computing, http://www.r-project.org). All data were tested for normal distribution using the Shapiro-Wilk test and for homogeneity of variances with the Levene test. To compare the carbon and nitrogen contents and enrichments in different plant fractions, mycorrhizal root tips, soil, litter and soil fauna, a linear model was used. Studentized residuals were detected with the Bonferroni Outlier test. Subsequently, a non-parametric KruskalWallis test was used to test significant differences between means followed by multiple comparisons of the data with the package nparcomp based on Pearson's product-moment correlation and non-parametric Behrens-Fischer problem (Brunner and Munzel, 2000). Mean \pm SE were calculated using original data. Spearman's rank correlation was used to test the relation of $\delta^{13} \mathrm{C}$ to $\delta^{15} \mathrm{~N}$ label in EM species and their corresponding fine roots, the relation of leaf area to $\delta^{13} \mathrm{C}$ and $\delta^{15} \mathrm{~N}$ label in EM species. Regression analysis was used to test the relation of $\delta^{13} \mathrm{C}$ and $\delta^{15} \mathrm{~N}$ label in mycorrhizal root tips (EM) and mycorrhizal root tip corresponding fine roots (RM). In all analyses, differences were considered significant when $P \leq 0.05$.

\subsection{Results}

\subsubsection{Carbon and nitrogen allocation between plant tissues and soil organisms}

17 different EM and 29 invertebrates were recorded (Supplement Table S1, S2). The vital root tips were on average 96\% ( $\pm 3 \%)$ colonised with EM. 13 EM species were identified through ITS sequence data and phylogenetic analysis (Supplement Table S1, Supplement Fig. S2). Three of these were ascomycota (Cenococcum geophilum, Peziza succosa and the unknown ascomycet MT 17); the remaining species belonged to the basidiomyceta.

The $\delta{ }^{15} \mathrm{~N}$ ratio was highest in EM colonized root tips and decreased along the uptake and transport route from roots to leaves (Fig. 4.1 A). The $\delta{ }^{15} \mathrm{~N}$ label of the EM root tips $(P=$ $0.003)$ and the fine roots associated with the mycorrhizal root tips were significantly higher $(P$ $\leq 0.001$ ) than that of the other plant fractions (Fig. 4.1) or non-labelled beech fine roots in field conditions $\left(7.21 \pm 2 \%\right.$ ) . The lowest $\delta^{15} \mathrm{~N}$ signatures were found in soil $(252 \pm 172 \%$ o and leaf litter $(607 \pm 540 \%)$, both enriched compared to field conditions, where litter layer $\delta^{15} \mathrm{~N}$ values of approximately $-3.7 \%$ in beech dominated mixed forests have been recorded 
(Scheu \& Falca 2000). The $\delta^{15} \mathrm{~N}$ ratio of soil fauna was higher than that of soil $(661 \pm 553$ \%o), but clearly below that of plant tissues and their associated EM (Fig. 4.1 A).

The stable isotope $\delta^{13} \mathrm{C}$ ratio showed an increase from distant plant fractions such as the stem to the mycorrhizal root tip. Furthermore, the $\delta^{13} \mathrm{C}$ label was significantly higher $(P \leq 0.001)$ in the mycorrhizal root tips than in any other fraction (Fig $4.1 \mathrm{~B}) . \delta^{13} \mathrm{C}$ label in soil fauna was higher than in soil or leaf litter (Fig $4.1 \mathrm{~B})$, whose labels were low ( $-23 \pm 3 \%$ ).

\subsubsection{EM mediated $N$ uptake and transfer in relation to carbon incorporation}

A regression analysis showed a strong positive relationship between $\delta^{15} \mathrm{~N}$ label in the mycorrhizal root tips and mycorrhiza-attached fine roots $(y=0.005+0.46 x, r=0.630 P=$ 0.0001), whereas no relationship was detected between the $\delta^{13} \mathrm{C}$ ratio in the mycorrhizal root tips and mycorrhiza attached fine roots $(y=65.5+0.30 x, r=0.182, P=0.088)$. 

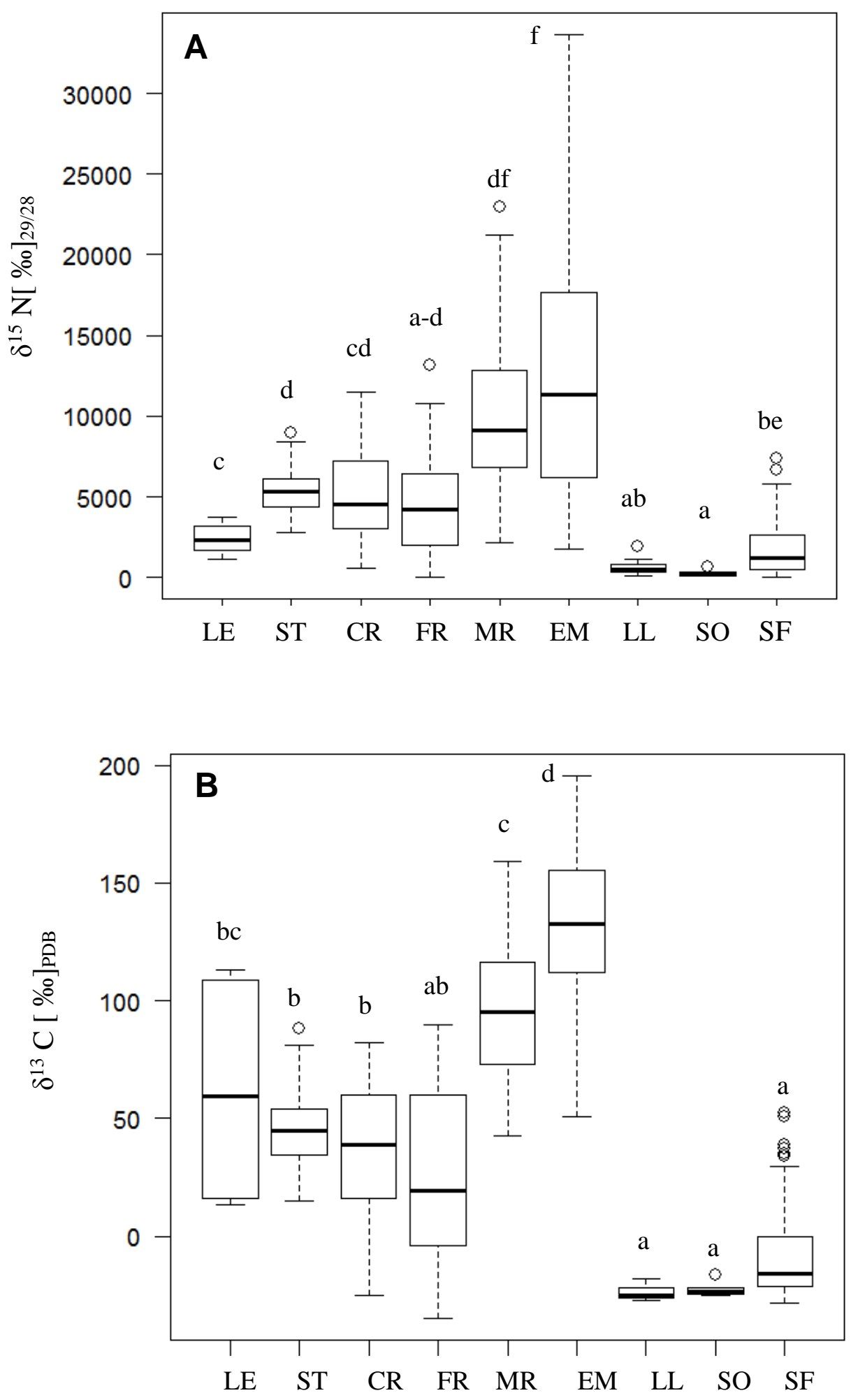

Figure 4.1: $\delta^{15} \mathrm{~N}(\mathrm{~A})$ and $\delta^{13} \mathrm{C}(\mathrm{B})$ in leaves (LE), stem (ST), coarse roots (CR), fine roots (FR), fine roots attached to mycorrhiza (MR), ectomycorrhizal root tips (EM), soil (SO), leaf litter (LL) and soil fauna (SF). The boxes indicate the 25th and 75th percentile, the horizontal line the 50th percentile and the whiskers within the 1.5 interquartile range. 


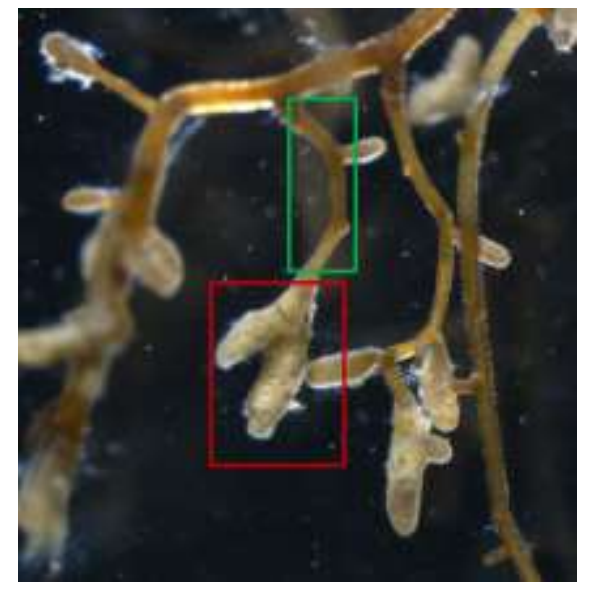

Figure 4.2: Mycorrhizal rot tip (red square) and fine root adjacent to mycorrhizal root tip (green square)

Since the acquisition of ${ }^{15} \mathrm{~N}$ and ${ }^{13} \mathrm{C}$ may also be affected by the concentration of $\mathrm{N}$ and $\mathrm{C}$ in the tissues, the specific enrichment ${ }^{15} \mathrm{~N}$ (atom\%) and ${ }^{13} \mathrm{C}$ (atom\%) was analysed (Fig. 4.2, 4.3). The ${ }^{15} \mathrm{~N}$ enrichment in root adjacent to EM was strongly related to the ${ }^{15} \mathrm{~N}$ label of the EM (Fig 4.3 A, $y=1.44+0.54 x, r=0.750, P=7.01 \times 10^{-6}$ ); whereas the ${ }^{13} \mathrm{C}$ enrichment in EM was not related to the ${ }^{13} \mathrm{C}$ enrichment in adjacent roots (Fig $4.3 \mathrm{~B}, y=0.84+0.30 x, r=$ $0.184, P=0.086)$.
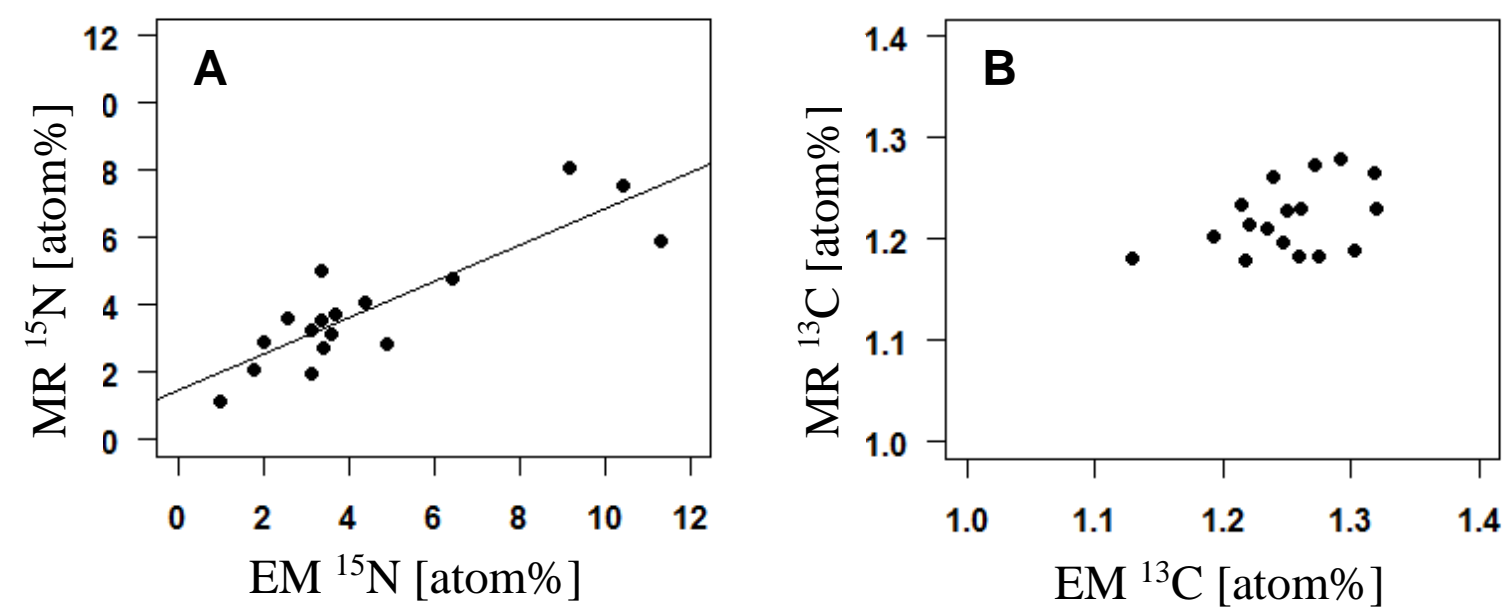

Figure 4.3: Relation between specific ${ }^{15} \mathrm{~N}(\mathrm{~A})$ and ${ }^{13} \mathrm{C}(\mathrm{B})$ signatures in ectomycorrhizal root tips (EM) and their corresponding fine roots (MR).

The ${ }^{15} \mathrm{~N}$ enrichment in EM was not related to its ${ }^{13} \mathrm{C}$ enrichment $(y=10201.23+19.53 x, r=$ 0.006, $P=0.673$ ). Similarly, no relationship was found between the ${ }^{15} \mathrm{~N}$ enrichment in mycorrhiza-attached roots and the ${ }^{13} \mathrm{C}$ enrichment in these roots $(y=75.51+0.002 x, r=$ $0.150, P=0.092)$. 
We found a negative correlation $\left(P=0.03, \mathrm{r}_{\mathrm{s}}=-0.46\right)$ between the ${ }^{13} \mathrm{C}$ enrichment in the mycorrhizal root tips and the specific leaf area (SLA). Also a correlation was found between ${ }^{15} \mathrm{~N}$ enrichment of the mycorrhizal root tips and specific leaf area $\left(P=0.05, \mathrm{r}_{\mathrm{s}}=0.42\right)$. However, this relation could not be followed up within one fungal species.

\subsubsection{Trophic relations of soil fauna, beech and ectomycorrhizal fungi}

EM root tips formed a group with the strongest increases in both $\delta^{15} \mathrm{~N}$ and $\delta^{13} \mathrm{C}$ compared to roots and invertebrates (Fig. 4.4). The highest $\delta^{13} \mathrm{C}$ label compared to fine roots was found in predators $(-1.7 \pm 29 \%$ ) followed by some species of decomposers soil animal taxa $(-54.0 \pm$ $36 \%)$. Unexpected, putative fungivore species did have rather low ${ }^{13} \mathrm{C}$ label $(-0.1 \pm 29 \%$ o (Fig. 4.4). Eight of the 29 invertebrate species displayed $\delta^{13} \mathrm{C}$ enrichment compared to fine roots (Fig 4.4). These species included three species of the genus Lithobius ( $L$. erythrocephalus $51.98 \%$, L. curtipes $27.22 \%$, and L. forficatus $19.51 \%$ ), which are predators. Other predators had significantly lower values $(-31.98 \pm 29.23 \%$ ). This result indicates that Lithobius species have a different diet than the other analysed predators. A wood louse Trichoniscus pusillus had a $\delta^{13} \mathrm{C}$ level of $50.154 \%$ highly related to ectomycorrhizas.

Mesofauna species with the highest $\Delta^{13} \mathrm{C}$ ratios were the oribatida mite Hypochthonius luteus (4.44\%) and two collembolan species (Lepidocyrtus cyaneus $-17.52 \pm 35.20 \%$ and Sinella/Pseudosinella -10.99\%). Endogeic earthworms (Apporectodea rosea, Octolasion tyrtaeum, $1.59 \pm 0.18$ ) had $\delta^{13} \mathrm{C}$ ratios corresponding to fine roots. Also Lumbricus rubellus had a high $\Delta^{13} \mathrm{C}$ ratio $(19.0 \%$ ). The ratios of these three earthworms were higher than the values for the known anecic earthworm Lumbricus terrestris $(-37.34 \pm 26 \%$ o) and compost earthworms E. octaedra and E. tetraedra $(-57.70 \pm 17.02 \%)$. 


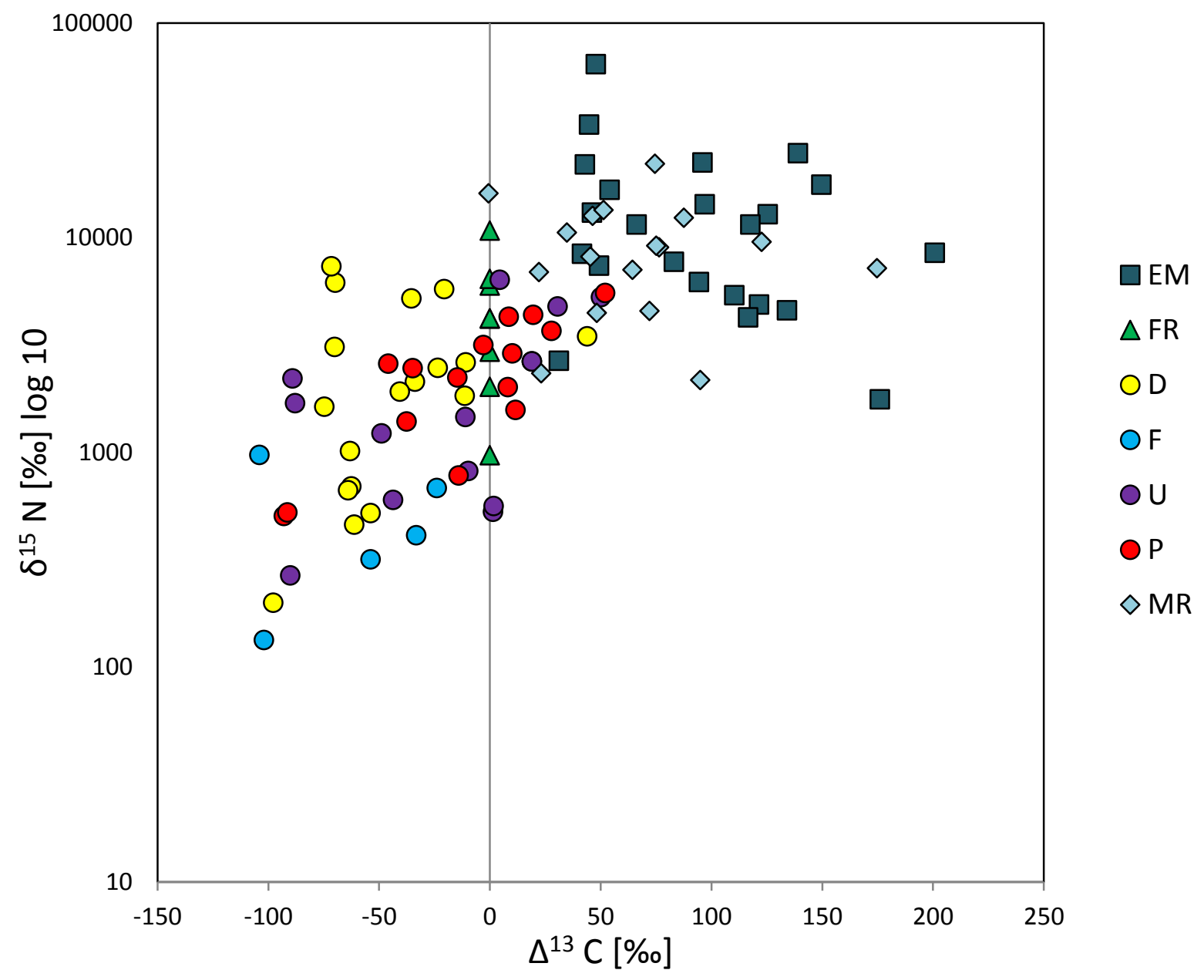

Figure 4.4: Enrichment of $\delta^{15} \mathrm{~N}$ and $\delta^{13} \mathrm{C}$ through the food web. $\delta^{13} \mathrm{C}$ signatures were normalized for fine roots.

Only one of the seven analysed oribatida mites, H. luteus had a $\delta^{13} \mathrm{C}$ label higher than the fine roots $(+4.44 \%)$. The putative fungivorous oribatida species; Nothrus palustris, Damaeidae and myriapoda Craspedosoma sp. $\left(-54.5 \pm 33 \%\right.$ ) did not show mycorrhiza-related $\delta^{13} \mathrm{C}$ labels. Other oribatida mites of as yet unknown trophic level, i.e., Hermaniella sp. and Xenillus sp. had ratios near to known detritus-feeding oribatida $(-69.9 \pm 0.1 \%$ ). This would indicate that these species are not exclusive mycorrhiza feeders, but rather detritivores. 


\subsection{Discussion}

\subsubsection{The experimental setup maintain a fungal beech EM community}

Experiments based on interactions between mycorrhiza and root-feeding soil fauna are often done in laboratory conditions with sterilised soil and controlled inoculation of fungi and insects, or in the field using fungicides. Both methods can have unwanted effects on the system leading to bias in the experimental setup (Koricheva et al. 2009). Furthermore pronounced host-fungal preferences exist (Lang et al. 2011), and the effects of the symbiosis can differ between fungal strains (Nygren \& Rosling 2009). In spite of the limitations of in vitro experiments, Johnson et al. 2012 emphasized the need of approaches under controlled conditions for resolving ecological questions.

In order to maintain a natural rhizosphere we used naturally regenerated seedlings from a forest that were kept in intact soil cores with their natural soil community. However, elevated $\mathrm{CO}_{2}$ used could have lead to shifts in the carbon allocation process, mycorrhizal biomass and community structure (Fransson 2012, Parrent \& Vilgalys 2009, Wiemken et al. 2001). Regardless of this, five months after the initiation of our greenhouse experiment mycorrhizal colonisation of the plants was comparable to that found in natural forests (Lang et al. 2011). C. geophilum, L. subdulcis and Tomentella spp. were the most frequently recorded species on beech roots. These and other species found have been reported as EM of beech trees in Hainich national park (Lang \& Polle 2011) and therefore we assume that the EM community was similar to the natural stand of the beech trees.

\subsubsection{High nitrogen accumulation in ectomycorrhizal fungi}

We found an increasing shift of $\delta^{13} \mathrm{C}$ and $\delta^{15} \mathrm{~N}$ from plants to fine roots attached to mycorrhiza. This demonstrates that a considerable part of the nitrogen taken up by the EM is directly transported to the plant and not fixed in the hyphal structures. On the other hand, EM is a strong sink of plant-mediated carbon. Similar to Högberg et al. (2008), we found highly heterogeneous ${ }^{13} \mathrm{C}$ levels in EM root tips. The carbon productivity of plants has been shown to depend, amongst other factors, on specific leaf area (McMurtrie \& Dewar 2011). In our experiment ${ }^{13} \mathrm{C}$ enrichment in the mycorrhizal root tips was negatively related to specific leaf area. At high nutrient availability plant growth is rather carbon-limited; therefore it has been 
suggested, that bigger plants might have less carbon available for investment to mycorrhizas (Yanai et al. 1995). In contrast, the ${ }^{15} \mathrm{~N}$ labels of the mycorrhizal root tips were positively correlated to SLA.

No correlation between $\delta^{15} \mathrm{~N}$ and $\delta^{13} \mathrm{C}$ enrichment of the EM was found. This result is in disagreement with Högberg et al. (2008), who found a positive correlation of N and C labels in ECM root tip. A longer labelling period and a higher label of our experiment compared to the experiment of Högberg et al. (2008) might influence the relation of nitrogen and carbon in mycorrhizal root tips differently. Furthermore, our results indicate that the plant leaf area or other factors affect plant carbon allocation and nitrogen uptake. For instance the patchiness of the available nitrogen in the soil can contribute to the differences in the nitrogen concentration of the mycorrhizal root tips and in carbon allocation processes (Corrêa et al. 2011, Kytöviita 2005, Rosling, Lindahl \& Finlay, Wallander et al. 2002). In our study, however, the plants were regularly irrigated with ${ }^{15} \mathrm{~N}$ fertilizer, and we therefore assume no high patchiness of the ${ }^{15} \mathrm{~N}$ label.

The $\delta^{13} \mathrm{C}$ enrichment differed between EM species up to $50 \%$. Previously we demonstrated that plant productivity and the amount of plant mediated carbon affect the carbon allocation to the mycorrhizal root tips (Druebert et al. 2009). Ecological theories hold that carbon investment is higher to more beneficial fungal associates (Bruns et al. 2002, Corrêa et al. 2008), however, studies with contrasting results exist. Plant belowground carbon allocation was showed rather to relate with soil nitrogen availability than with actual nitrogen gain through mycorrhiza. Also indications that host plants continue to invest carbon to mycorrhiza by decreasing nitrogen supply has been found (Corrêa et al. 2011, Corrêa et al. 2008). The individual root tips have been suggested to receive different amounts of carbon depending on mycorrhizal species or intra specific differences between fungi (Johnson et al. 2012). In our experiment, low numbers of individual species precluded statistical analysis of this phenomenon.

Nevertheless, we presume that EM species differ in their ability to allocate nitrogen to the host. If plants provide mycorrhiza with more efficient nitrogen supply with increased carbon allocation we would expect a direct correlation of carbon and nitrogen labels found in mycorrhizal root tips. In our experiment however nitrogen and carbon allocation were not directly related. This leads to the conclusion that plant carbon allocation did not depend on nitrogen label of mycorrhizal root tips or vice versa. However, the fact that nitrogen and 
carbon allocation were not directly related could indicate that EM with lower nitrogen accumulation allocate other resources such as other nutrient elements or water (Rosling, Lindahl \& Finlaya, Rosling, Lindahl, Taylor b, Wallander et al. 2002).

\subsubsection{EMs have a high nutritional value}

We showed that the mycorrhizal root tips and the fine roots attached to the mycorrhiza had the highest $\mathrm{C}$ and $\mathrm{N}$ enrichment of the entire root system. This would make root tips nutritionally more attractive to root feeders. In fact, herbivore soil animals have been reported to prefer to feed on root tips (Bonkowski \& Roy 2005, Rodger et al. 2003).

We found soil fauna species with an enriched $\delta^{13} \mathrm{C}$ signature compared to fine roots, but the enrichment was on average five times lower than the label found in mycorrhizal root tips $\left(96.86 \pm 38.69 \%\right.$ vs. $-26.52 \pm 38.41 \%$ ). The highest $\delta^{13} \mathrm{C}$ label compared to fine roots was found in predators followed by fungivore species. The decomposers had the lowest $\Delta^{13} \mathrm{C}$ values. The species with currently unknown trophic position were positioned between decomposers and putative fungal feeder, suggesting these species to have a mixed diet.

In this experiment we measured the EM ${ }^{13} \mathrm{C}$ and ${ }^{15} \mathrm{~N}$ labels in mycorrhizal root tips. Thus a distinction between labels in different mycorrhizal structures was not possible, the separation of mycorrhizal root tips and extramatrical mycelium as food source of soil animals was partly based on available information about the behavior and ecology of the found soil animals.

The most similar isotopic $\delta^{13} \mathrm{C}$ ratios to mycorrhizal root tips were found in macrofaunal species, which have no direct trophic links to mycorrhizas. The isotopic $\Delta^{13} \mathrm{C}$ ratios of the predatory species Lithobius erythrocephalus (51.98\%), Hypochthonius luteus and an isopoda species, Trichoniscus pusillus (50.15\%) corresponded with the $\Delta^{13} \mathrm{C}$ label of ectomycorrhizal root tips. T. pusillus have been earlier shown to feed on litter colonizing microbiota (Kautz et al. 2000). Presumably leaf litter grazed by $T$. pusillus could be incorporated with ectomycorrhizal mycelia (Hrynkiewicz et al. 2010, Perez-Moreno \& Read 2000), but also other carbon sources like the bacterial food channel cannot be excluded.

L. erythrocephalus and $H$. luteus have indirect trophic links to mycorrhizas through feeding on mycorrhizal-nourished prey (Maraun 2012). Isotopic values of predators and secondary decomposers have been found to resemble each other (Maraun 2012). We found a significant difference between $\Delta^{13} \mathrm{C}$ values of these trophic groups. Predators with intermediate ${ }^{13} \mathrm{C}$ enrichment presumably feed on mixed prey. Our results suggest EM to be a possible carbon 
source for both trophic groups. Still, explicit work is needed to distinguish the bacterial and fungal nutrient channels.

The comparison of $\Delta^{13} \mathrm{C}$ ratios of anecic earthworm L. terrestris (-37.34\%o) with earth worms from other ecotypes (compost earthworms, epigeic earthworms and endogeic earthworms) showed that the endogeic species Apporectodea rosea and Octolasion tyrtaeum had a $\delta^{13} \mathrm{C}$ enrichment similar to that of fine roots. However these results are based on single measurements. In contrast, the epigeic Eiseniella species E. octaedra and E. tetraedra (-57.70 $\pm 17.02 \%$ ) have much lower $\Delta^{13} \mathrm{C}$ values. This is in accordance with an earlier suggestion that these species feed presumably on leaf litter (Scheu \& Falca 2000). Another epigeic species Lumbricus rubellus differed clearly from these two species, by having a higher $\Delta^{13} \mathrm{C}$ ratio (19.0\%). A. rosea and $O$. tyrtaeum have been suggested to feed on older and more humified litter (Maraun 2012). Our findings suggest endogeic and epi-endogeic earth worms to have a possible indirect link to plant carbon, which might rely on older litter with incorporated EM mycelium or recalcitrant carbon from dead hyphae in deeper soil layers (Langley et al. 2006).

An oribatid mite from the Family Hypochthoniidae, Hypochthonius luteus (4.44 \%o), showed a fine root related enrichment of the $\delta^{13} \mathrm{C}$ label. We expected putative fungivore oribatid mites Nothrus palustris $(-53.74 \pm 35.75 \%)$ and Damaeidae $(-77.95 \pm 24.06)$ to be enriched in $\delta^{13} \mathrm{C}$ compared to fine roots. However, no corresponded $\delta^{13} \mathrm{C}$ enrichment was found. We suggest both species to feed on saprophytic fungi or litter.

We found two collembolan species from the family Entomobryoidea, Lepidocyrtus cyaneus ($17.51 \pm 35.20 \%$ o $)$ and Sinella/Pseudosinella spec. $\left(-10.99 \%\right.$ ), enriched with $\delta^{13} \mathrm{C}$. Högberg et al. (2010), found that Collembolan species from the family Entomobryoidea are rapidly labeled with tree derived ${ }^{13} \mathrm{C}$, and suggested that they feed upon highly active mycelia. Because the label levels were much higher than in the leaf litter (Fig. 4.4), but lower than in EM, we presume that Entomobryoidea might have a mixed diet that includes mycorrhizas, fine roots or both. This result is in accordance with Pollierer et al. (2007) who suggested Entomobryidae (Collembola) to acquire root and leaf litter derived carbon in similar amounts. 


\subsection{Conclusions}

Our results show that the mycorrhizal root tips and the fine roots attached to the mycorrhizas have the highest ${ }^{13} \mathrm{C}$ and ${ }^{15} \mathrm{~N}$ enrichment compared to other plant structures. Also we found a strong relationship between nitrogen concentration in mycorrhizal root tips and adjacent fine roots. This indicates that a notable amount of nitrogen in EM is directly allocated to the host plant. Similar relations were neither found between carbon concentrations in mycorrhizal root tips and adjacent fine roots, nor between carbon and nitrogen enrichment in mycorrhizal root tips. Due to the high nitrogen concentrations in mycorrhizal root tips EM can be concidered to have a high nutritional value. Our results demonstrate that soil animal species from all trophic levels potentially connect to EM fungi. However, explicit work is still needed to distinguish between bacterial and fungal nutrient channels, as well as between mycorrhizal root tip and EM mycelia as nutrient sources of soil animals. Finally, EM fungi are pivotal as a nutrient channel not only to the host plant but also for the soil food web. 


\subsection{References}

Agerer, R. (1987-2006), ‘Colour atlas of Ectomycorrhizae’, Einhorn Verlag, Schwäbisch Gmünd.

Bais, H. P., Weir, T. L., Perry, L. G., Gilroy, S. \& Vivanco, J. M. (2006), 'The role of root exudates in rhizosphere interactions with plants and other organisms', Annual Review of Plant Physiolog y and Plant Molecular Biology 57, 233-266.

Bonkowski, M. \& Roy, J. (2005), 'Soil microbial diversity and soil functioning affect competition among grasses in experimental microcosms', Oecologia 143(2), 232-240.

Bonkowski, M., Villenave, C. \& Griffiths, B. (2009), 'Rhizosphere fauna: the functional and structural diversity of intimate interactions of soil fauna with plant roots', Plant and Soil 321, 213-233.

Bruns, T. D., Bidartondo, M. I. \& Taylor, D. L. (2002), 'Host specificity in ectomycorrhizal communities: what do the exceptions tell us?', Integrative and Comparative Biology 42(2), 352-359.

Corrêa, A., Hampp, R., Magel, E. \& Martins-Loução, M. A. (2011), 'Carbon allocation in ectomycorrhizal plants at limited optimal $\mathrm{N}$ supply: an attempt at unraveling conflicting theories', Mycorrhiza 21(1), 35-51.

Corrêa, A., Strasser, R. J. \& Martins-Loução, M. A. (2008), 'Response of plants to ectomycorrhizae in N-limited conditions: which factors determine its variation?', Mycorrhiza 18(8), 413-427.

Courty, P.-E., Pritsch, K., Schloter, M., Hartmann, A. \& Garbaye, J. (2005), 'Activity profiling of ectomycorrhiza communities in two forest soils using multiple enzymatic tests', New Phytologist 167(1), 309-319.

Druebert, C., Lang, C., Valtanen, K. \& Polle, A. (2009), 'Beech carbon productivity as driver of ectomycorrhizal abundance and diversity', Plant, Cell \& Environment 32(8), 992-1003.

Durall, D. M., Todd, A. W. \& Trappe, J. M. (1994), 'Decomposition of ${ }^{14}$ C-labelled substrates by ectomycorrhizal fungi in association with Douglas fir', New Phytologist 127(4), 725-729.

Fransson, P. (2012), 'Elevated $\mathrm{CO}_{2}$ impacts ectomycorrhiza-mediated forest soil carbon flow: fungal biomass production, respiration and exudation', Fungal Ecology 5, 8598.

Fransson, P. M. A. \& Johansson, E. M. (2010), 'Elevated $\mathrm{CO}_{2}$ and nitrogen influence exudation of soluble organic compounds by ectomycorrhizal root systems', FEMS Microbiology Ecology 71(2), 186-196. 
Gadd, G. M. (2007), 'Geomycology: biogeochemical transformations of rocks, minerals, metals and radionuclides by fungi, bioweathering and bioremediation', Mycological Research 111(1), 3-49.

Gardes, M. \& Bruns, T. (1993), 'ITS primers with enhanced specificity for basidiomycetes application to the identification of mycorrhizae and rusts', Molecular Ecology 2(2), 113-118.

Gebauer, G. \& Dietrich, P. (1993), 'Nitrogen isotope ratios in different compartments of a mixed stand of spruce, larch and beech trees and of understorey vegetation including fungi', Isotopes in Environmental and Health Studies 29(1), 35-44.

Gebauer, G. \& Taylor, A. F. S. (1999), ${ }^{15} \mathrm{~N}$ natural abundance in fruit bodies of different functional groups of fungi in relation to substrate utilization', New Phytologist 142(1), 93-101.

Godbold, D. L., Hoosbeek, M. R., Lukac, M., Cotrufo, M. F., Janssens, I. A., Ceulemans, R., Polle, A., Velthorst, E. J., Scarascia-Mugnozza, G., De Angelis, P., Miglietta, F. \& Peressotti, A. (2006), 'Mycorrhizal hyphal turnover as a dominant process for carbon input into soil organic matter', Plant and Soil 281, 15-24.

Gouy, M., Guindon, S. \& Gascuel, O. (2010), 'Seaview version 4: A multiplatform graphical user interface for sequence alignment and phylogenetic tree building', Molecular Biology and Evolution 27, 221-224.

Graham, J. H. (2001), 'What do root pathogens see in mycorrhizas?', New Phytologist 149(3), $357-359$.

Hempel, S., Stein, C., Unsicker, S. B., Renker, C., Auge, H., Weisser, W. W. \& Buscot, F. (2009), 'Specific bottom-up effects of arbuscular mycorrhizal fungi across a plant-herbivore-parasitoid system', Oecologia 160(2), 267-277.

Högberg, M. N., Briones, M. J. I., Keel, S. G., Metcalfe, D. B., Campbell, C., Midwood, A. J., Thornton, B., Hurry, V., Linder, S., Näsholm, T. \& Högberg, P. (2010), 'Quantification of effects of season and nitrogen supply on tree below-ground carbon transfer to ectomycorrhizal fungi and other soil organisms in a boreal pine forest', New Phytologist 187(2), 485-493.

Högberg, M. N. \& Högberg, P. (2002), 'Extramatrical ectomycorrhizal mycelium contributes one-third of microbial biomass and produces, together with associated roots, half the dissolved organic carbon in a forest soil', New Phytologist 154(3), 791795. 
Högberg, P., Högberg, M. N., Göttlicher, S. G., Betson, N. R., Keel, S. G., Metcalfe, D. B., Campbell, C., Schindlbacher, A., Hurry, V., Lundmark, T., Linder, S. \& Näsholm, T. (2008), 'High temporal resolution tracing of photosynthate carbon from the tree canopy to forest soil microorganisms', New Phytologist 177(1),220228.

Högberg, P., Plamboeck, A. H., Taylor, A. F. \& Fransson, P. M. (1999), 'Natural (13)C abundance reveals trophic status of fungi and host-origin of carbon in mycorrhizal fungi in mixed forests', Proceedings of the National Academy of Sciences of the United States of America 96(15), 8534-8539.

Hiol, F. H., Dixon, R. K. \& Curl, E. A. (1994), 'The feeding preference of mycophagous Collembola varies with the ectomycorrhizal symbiont', Mycorrhiza 5(2), 99103.

Hoffmann, D., Vierheilig, H., Peneder, S. \& Schausberger, P. (2011), 'Mycorrhiza modulates aboveground tri-trophic interactions to the fitness benefit of its host plant', Ecological Entomology 36, 574-581.

Hoffmann, D., Vierheilig, H., Riegler, P. \& Schausberger, P. (2009), ‘Arbuscular mycorrhizal symbiosis increases host plant acceptance and population growth rates of the two-spotted spider mite Tetranychus urticae', Oecologia 158(4), 663-671.

Hrynkiewicz, K., Ciesielska, A., Haug, I. \& Baum, C. (2010), 'Ectomycorrhiza formation and willow growth promotion as affected by associated bacteria: role of microbial metabolites and use of C sources', Biology and Fertility of Soils 46(2), 139-150.

Jany, J.-L., Martin, F. \& Garbaye, J. (2003), 'Respiration activity of ectomycorrhizas from Cenococcum geophilum and Lactarius sp. in relation to soil water potential in five beech forests', Plant and Soil 255(2), 487-494.

Johnson, D., Martin, F., Cairney, J. W. G. \& Anderson, I. C. (2012), 'The importance of individuals: intraspecific diversity of mycorrhizal plants and fungi in ecosystems', New Phytologist 194(3), 614-628.

Kautz, G., Zimmer, M., \& Topp, W. (2000), 'Responses of the parthenogenetic isopod, Trichoniscus pusillus (Isopoda: Oniscidea) to changes in food quality', Pedobiologia 44, 75-85.

Kõljalg, U., Larsson, K.-H., Abarenkov, K., Nilsson, R. H., Alexander, I. J., Eberhardt, U., Erland, S., Høiland, K., Kjøller, R., Larsson, E., Pennanen, T., Sen, R., Taylor, A. F. S., Tedersoo, L., Vrålstad, T. \& Ursing, B. M. (2005), 'UNITE: a database providing web-based methods for the molecular identification of ectomycorrhizal fungi', New Phytologist 166(3), 1063-1068.

Koricheva, J., Gange, A. C. \& Jones, T. (2009), 'Effects of mycorrhizal fungi on insect herbivores: a meta-analysis', Ecology 90(8), 2088-2097. 
Kytöviita, M.-M. (2005), 'Role of nutrient level and defoliation on symbiotic function: experimental evidence by tracing ${ }^{14} \mathrm{~N} /{ }^{15} \mathrm{~N}$ exchange in mycorrhizal birch seedlings', Mycorrhiza 15(1), 65-70.

Landeweert, R., Hoffland, E., Finlay, R. D., Kuyper, T. W. \& van Breemen, N. (2001), 'Linking plants to rocks: ectomycorrhizal fungi mobilize nutrients from minerals', Trends in Ecology and Evolution 16(5), 248-254.

Lang, C. \& Polle, A. (2011), 'Ectomycorrhizal fungal diversity, tree diversity and root nutrient relations in a mixed Central European forest', Tree Physiology 31(5), $531-538$.

Lang, C., Seven, J. \& Polle, A. (2011), 'Host preferences and differential contributions of deciduous tree species shape mycorrhizal species richness in a mixed Central European forest', Mycorrhiza 21(4), 297-308.

Langley, J. A., Chapman, S. K. \& Hungate, B. A. (2006), 'Ectomycorrhizal colonization slows root decomposition: the post-mortem fungal legacy', Ecology Letters 9(8), 955-959.

Leuschner, C., Jungkunst, H. F. \& Fleck, S. (2009), 'Functional role of forest diversity: Pros and cons of synthetic stands and across-site comparisons in established forests', Basic and Applied Ecology 10, 1-9.

Lilleskov, E. A. \& Bruns, T. D. (2005), 'Spore dispersal of a resupinate ectomycorrhizal fungus, Tomentella sublilacina, via soil food webs', Mycologia 97(4), 762-769.

McMurtrie, R. E. \& Dewar, R. C. (2011), 'Leaf-trait variation explained by the hypothesis that plants maximize their canopy carbon export over the lifespan of leaves', Tree Physiology 31(9), 1007-1023.

Nygren, C. M. R. \& Rosling, A. (2009), 'Localisation of phosphomonoesterase activity in ectomycorrhizal fungi grown on different phosphorus sources', Mycorrhiza 19(3), 197-204.

Parrent, J. L. \& Vilgalys, R. (2009), 'Expression of genes involved in symbiotic carbon and nitrogen transport in Pinus taeda mycorrhizal roots exposed to $\mathrm{CO}_{2}$ enrichment and nitrogen fertilization', Mycorrhiza 19(7), 469-479.

Perez-Moreno, J. \& Read, D. (2000), 'Mobilization and transfer of nutrients from litter to tree seedlings via the vegetative mycelium of ectomycorrhizal plants', New Phytologist 145(2), 301-309.

Pollierer, M. M., Langel, R., Körner, C., Maraun, M. \& Scheu, S. (2007), 'The underestimated importance of belowground carbon input for forest soil animal food webs', Ecology Letters 10(8), 729-736. 
Pollierer, M. M., Langel, R., Körner, C., Maraun, M. \& Scheu, S. (2009), 'Compartmentalization of the soil animal food web as indicated by dual analysis of stable isotope ratios $\left({ }^{15} \mathrm{~N} /{ }^{14} \mathrm{~N}\right.$ and $\left.{ }^{13} \mathrm{C} /{ }^{12} \mathrm{C}\right)$ ', Soil Biology \& Biochemistry 41, 12211226.

Pollierer, M. M., Dyckmans, J., Scheu, S. \& Haubert, D. (2012), 'Carbon flux through fungi and bacteria into the forest soil animal food web as indicated by compoundspecific ${ }^{13} \mathrm{C}$ fatty acid analysis', Functional Ecology 26, 978-990.

Read, D. J. \& Perez-Moreno, J. (2003), 'Mycorrhizas and nutrient cycling in ecosystems - a journey towards relevance?', New Phytologist 157(3), 475-492.

Rodger, S., Bengough, A. G., Griffiths, B. S., Stubbs, V. \& Young, I. M. (2003), 'Does the presence of detached root border cells of Zea mays alter the activity of the pathogenic nematode Meloidogyne incognita?', Phytopathology 93(9), 11111114.

Rosling, A., Lindahl, B. D. \& Finlay, R. D. (2004a), 'Carbon allocation to ectomycorrhizal roots and mycelium colonising different mineral substrates', New Phytologist 162(3), 795-802.

Rosling, A., Lindahl, B. D., Taylor, A. F. S. \& Finlay, R. D. (2004b), 'Mycelial growth and substrate acidification of ectomycorrhizal fungi in response to different minerals', FEMS Microbiology Ecolology 47(1), 31-37.

Scheu, S. \& Falca, M. (2000), 'The soil food web of two beech forests (Fagus sylvatica) of contrasting humus type: stable isotope analysis of a macro- and a mesofaunadominated community', Oecologia 123(2), 285-296.

Scheu, S. \& Simmerling, F. (2004), 'Growth and reproduction of fungal feeding Collembola as affected by fungal species, melanin and mixed diets.', Oecologia 139(3), $347-353$.

Smith, S. \& Read, D. (1997), Mycorrhizal symbiosis, Academic Press, London, UK.

Trocha, L. K., Mucha, J., Eissenstat, D. M., Reich, P. B. \& Oleksyn, J. (2010), 'Ectomycorrhizal identity determines respiration and concentrations of nitrogen and non-structural carbohydrates in root tips: a test using Pinus sylvestris and Quercus robur saplings', Tree Physiol 30(5), 648-654.

van der Heijden, M. G. A., Bardgett, R. D. \& van Straalen, N. M. (2008), 'The unseen majority: soil microbes as drivers of plant diversity and productivity in terrestrial ecosystems.', Ecology Letters 11(3), 296-310.

Vinichuk, M. M. \& Johanson, K. J. (2003), 'Accumulation of ${ }^{137}$ Cs by fungal mycelium in forest ecosystems of Ukraine', Journal of Environmental Radioactivity 64, 2743. 
Wallander, H., Göransson, H. \& Rosengren, U. (2004), 'Production, standing biomass and natural abundance of ${ }^{15} \mathrm{~N}$ and ${ }^{13} \mathrm{C}$ in ectomycorrhizal mycelia collected at different soil depths in two forest types', Oecologia 139(1), 89-97.

Wallander, H., Johansson, L. \& Pallon, J. (2002), 'Pixe analysis to estimate the elemental composition of ectomycorrhizal rhizomorphs grown in contact with different minerals in forest soil', FEMS Microbiology Ecology 39(2), 147-156.

Wallander, H., Mahmood, S., Hagerberg, D., Johansson, L. \& Pallon, J. (2003), 'Elemental composition of ectomycorrhizal mycelia identified by PCR-RFLP analysis and grown in contact with apatite or wood ash in forest soil', FEMS Microbiology Ecology 44(1), 57-65.

Wallander, H., Nilsson, L. O., Hagerberg, D. \& Bååth, E. (2001), 'Estimation of the biomass and seasonal growth of external mycelium of ectomycorrhizal fungi in the field', New Phytologist 151, 753-760.

Wardle, D. A., Bardgett, R. D., Callaway, R. M. \& der Putten, W. H. V. (2011), 'Terrestrial ecosystem responses to species gains and losses.', Science 332(6035), 12731277.

White, T., Bruns, T., Lee, S. \& Taylor, J. (1990), Amplification and direct sequencing of fungal ribosomal RNA genes for phylogenetics. In: PCR protocols: a guide to methods and applications, Academic press, New York.

Wiemken, V., Laczko, E., Ineichen, K. \& Boller, T. (2001), 'Effects of elevated carbon dioxide and nitrogen fertilization on mycorrhizal fine roots and the soil microbial community in beech-spruce ecosystems on siliceous and calcareous soil', Microbiology Ecology 42(2), 126-135.

Yanai, R., Fahey, T. \& Miller, S. (1995), 'Resource physiology of conifers: acquisition, allocation, and utilization', Smith, W. K. and Hinckley, T. M. (Eds), Efficiency of nutrient acquisition by fine roots and mycorrhizae, Academic Press, New York. 
Supplementary data

Supplement Table S1: Molecular information of ectomycorrhizal species. Species were identified by ITS sequencing and sequence information was deposited in NCBI databank. If the homology was higher than $94 \%$ and the score higher than 700 bits, the name suggested by the database, preferentially that of UNITE was accepted. If both NCBI and UNITE database did suggest the same genus, species with higher score than 600 bits were named as unknown species of the suggested genera, unknown species clustering with known species were named as unknown species of the same genera, otherwise unknown ectomycorrhizas were called unknown species with an internal morphotype number (MT). Species for which sequence information was not available were called by their internal morphotype number (MT). ACC = Accession number in NCBI databank, Best BLAST match = name obtained from NCBI or UNITE, UncECM= Uncultured Ectomycorrhiza.

Supplement Table S2: Taxonomical (order/phylum) and ecological (ecology/diet) information of soil arthropods and their $\Delta^{13} \mathrm{C}$ enrichment. $\delta^{13} \mathrm{C}$ signatures were normalized for fine roots.

Supplement Figure S1: Phylogeny of EMF species based on ITS sequences. Maximum Likelihood, ML $\ln (\mathrm{L})=4066.9,657$ sites GTR 4 rate classes. The Bootstrap values were generated from 100 replicates 


\section{Supplement Table S1:}

\begin{tabular}{|c|c|c|c|c|c|c|c|}
\hline Species & $\begin{array}{l}\text { NCBI } \\
\text { Genbank } \\
\text { ACC } \\
\text { number }\end{array}$ & Best BLAST Match & Source & $\begin{array}{c}\text { Source } \\
\text { Accession } \\
\text { Database number } \\
\text { Best BLAST } \\
\text { Match } \\
\end{array}$ & $\begin{array}{l}\text { Length of } \\
\text { Fragment }\end{array}$ & $\begin{array}{c}\text { Homol } \\
\text { ogy } \\
{[\%]}\end{array}$ & $\begin{array}{l}\text { Score } \\
\text { [bits] }\end{array}$ \\
\hline Tomentella spec. 1 & JQ982963 & $\begin{array}{c}\text { Uncultured } \\
\text { Thelephoraceae clone } \\
\text { SC_ITS_157 }\end{array}$ & NCBI & GQ219960.1 & 685 & $100 \%$ & 1266 \\
\hline Tomentella spec. 2 & JQ982967 & $\begin{array}{c}\text { Uncultured } \\
\text { ectomycorrhiza } \\
\text { (Thelephoraceae) clone } \\
\text { M44C6 }\end{array}$ & NCBI & FJ196997.1 & 629 & 98 & 830 \\
\hline Tomentella spec. 4 & JQ982968 & $\begin{array}{c}\text { Tomentella galzinii } \\
\text { Uncultured }\end{array}$ & UNITE & UDB000263 & 553 & 95 & 844 \\
\hline Tomentella spec. 5 & JQ982969 & $\begin{array}{c}\text { Thelephoraceae clone } \\
\text { 6S4.22.S04 }\end{array}$ & NCBI & EF619818.1 & 256 & 93 & 856 \\
\hline Thelephora spec. 1 & JQ982964 & $\begin{array}{c}\text { Uncultured } \\
\text { ectomycorrhiza } \\
\text { (Thelephoraceae) clone } \\
\text { OT-76 }\end{array}$ & NCBI & FJ0130.1 & 475 & 100 & 878 \\
\hline Thelephora spec. 2. & JQ982978 & $\begin{array}{c}\text { Uncultured } \\
\text { Thelephoraceae clone } \\
\text { 6S4.22.S04 }\end{array}$ & NCBI & GQ219960.1 & 568 & 99 & 1031 \\
\hline $\begin{array}{l}\text { Clavulina cf. } \\
\text { cinerea }\end{array}$ & JQ982970 & $\begin{array}{l}\text { Clavulina cf. cinerea } \\
\text { BIO } 10304\end{array}$ & NCBI & EU862226 & 564 & 99 & 876 \\
\hline Hymenogaster spec. & JQ982975 & $\begin{array}{l}\text { Hymenogaster vulgaris } \\
\text { voucher RBG Kew } \\
\text { K(M) } 27363\end{array}$ & NCBI & EU784365.1 & 472 & 95 & 725 \\
\hline $\begin{array}{l}\text { Hymenogaster } \\
\text { rehsteineri }\end{array}$ & JQ982973 & $\begin{array}{c}\text { Hymenogaster } \\
\text { rehsteineri isolate } \\
\text { zb20070814 }\end{array}$ & NCBI & GU479324.1 & 572 & 100 & 1057 \\
\hline Lactarius subdulcis & JQ982974 & Lactarius subdulcis & UNITE & UDB000380 & 394 & 100 & 781 \\
\hline Russula spec. & JQ982979 & $\begin{array}{c}\text { Russula romellii 2- } \\
\text { 1119IS77 }\end{array}$ & NCBI & AY061714.1 & 388 & 97 & 652 \\
\hline Pestiza succosa & JQ982977 & $\begin{array}{c}\text { Peziza succosa voucher } \\
\text { KH-98-07 (C) }\end{array}$ & NCBI & DQ200840 & 586 & 99 & 1075 \\
\hline
\end{tabular}




\section{Supplement Table S2:}

\begin{tabular}{|c|c|c|c|c|}
\hline $\begin{array}{l}\text { Phylum/ } \\
\text { Order }\end{array}$ & Species & $\Delta^{13} \mathrm{C}[\% 0] \mathrm{PDB}$ & Diet & Trophic level \\
\hline Arachneida & Clubiona sp. & -14.66 & mixed prey* & predator \\
\hline Arachneida & Hahnia pusilla & $-20.22 \pm 17.4$ & mixed prey* & predator \\
\hline Coleoptera & Coleoptera A sp. & $-29.54 \pm 44.8$ & mixed diet* & unknown \\
\hline Collembola & Lepidocyrtus cyaneus & $-17.52 \pm 35.2$ & detridivore & secondary decompose \\
\hline Collembola & Sinella/Pseudosinella ssp. & -10.99 & $\begin{array}{l}\text { mixed diet* } \\
\text { litter with incorp }\end{array}$ & secondary decomposer \\
\hline Isopoda & Trichoniscus pusillus & 50.15 & EMF mycelium* & secondary decomposer \\
\hline Lumbricida & Aporrectodea caliginosa & $-66.10 \pm 22.5$ & $\begin{array}{l}\text { leaf litter* } \\
\text { leaf litter/fine root }\end{array}$ & primary decomposer \\
\hline Lumbricida & Apporectodea rosea & 1.41 & litter* & secondary decomposer \\
\hline Lumbricida & Eiseniella octaedra & -40.68 & leaf litter* & primary decomposer \\
\hline Lumbricida & Eiseniella tetraedra & -74.73 & leaf litter* & primary decomposer \\
\hline Lumbricida & Lumbricus terrestris & $-37.34 \pm 25.9$ & $\begin{array}{l}\text { leaf litter } \\
\text { old leaf litter with } \\
\text { incorp EMF }\end{array}$ & secondary decomposer \\
\hline Lumbricida & Lumbricus rubellus & 18.96 & $\begin{array}{l}\text { mycelium* } \\
\text { old leaf litter with } \\
\text { incorp EMF }\end{array}$ & secondary decomposer \\
\hline Lumbricida & Octolasion tyrtaeum & 1.77 & $\begin{array}{l}\text { mycelium* } \\
\text { leaf litter /saproph. }\end{array}$ & primary decomposer \\
\hline Myriapoda & Craspedosoma sp. & -34.17 & fungi* & secondary decomposer \\
\hline Myriapoda & Glomeris helvetica & -93.00 & leaf litter* & primary decomposer \\
\hline Myriapoda & Glomeris undulata & $-41.70 \pm 49.7$ & leaf litter* & primary decomposer \\
\hline Myriapoda & Lithobius curtipes & 27.77 & fungivore prey* & predator \\
\hline Myriapoda & Lithobius erythrocephalus & 51.98 & fungivore prey* & predator \\
\hline Myriapoda & Lithobius forficatus & 19.51 & fungivore prey* & predator \\
\hline Myriapoda & Lithobius muticus & $-12.32 \pm 22.5$ & mixed prey* & predator \\
\hline Myriapoda & Necrophleophagus & $-9.97 \pm 23.0$ & mixed prey* & predator \\
\hline Oribatida & Achipteria sp. & $-70.92 \pm 19.2$ & leaf litter & primary decomposer \\
\hline Oribatida & Damaeidae sp. & $-77.95 \pm 24.1$ & leaf litter* & primary decomposer \\
\hline Oribatida & Hermaniella sp. & -69.77 & leaf litter* & $\begin{array}{l}\text { primary decomposer } \\
\text { primary }\end{array}$ \\
\hline Oribatida & Hypochthonius luteus & 4.44 & fine roots* & consumer*predator \\
\hline Oribatida & Nothrus palustris & $-53.74 \pm 35.8$ & saphrohytic fungi* & Primary decomposer \\
\hline Oribatida & Platynothrus peltifer & -71.60 & decomposer & primary decomposer \\
\hline Oribatida & Stegacarus magnus & $-27.99 \pm 7.4$ & leaf litter & primary decomposer \\
\hline Oribatida & Xenillus sp. & -70.05 & detritus & decomposer/detritivore \\
\hline
\end{tabular}




\section{Supplement Figure S1:}

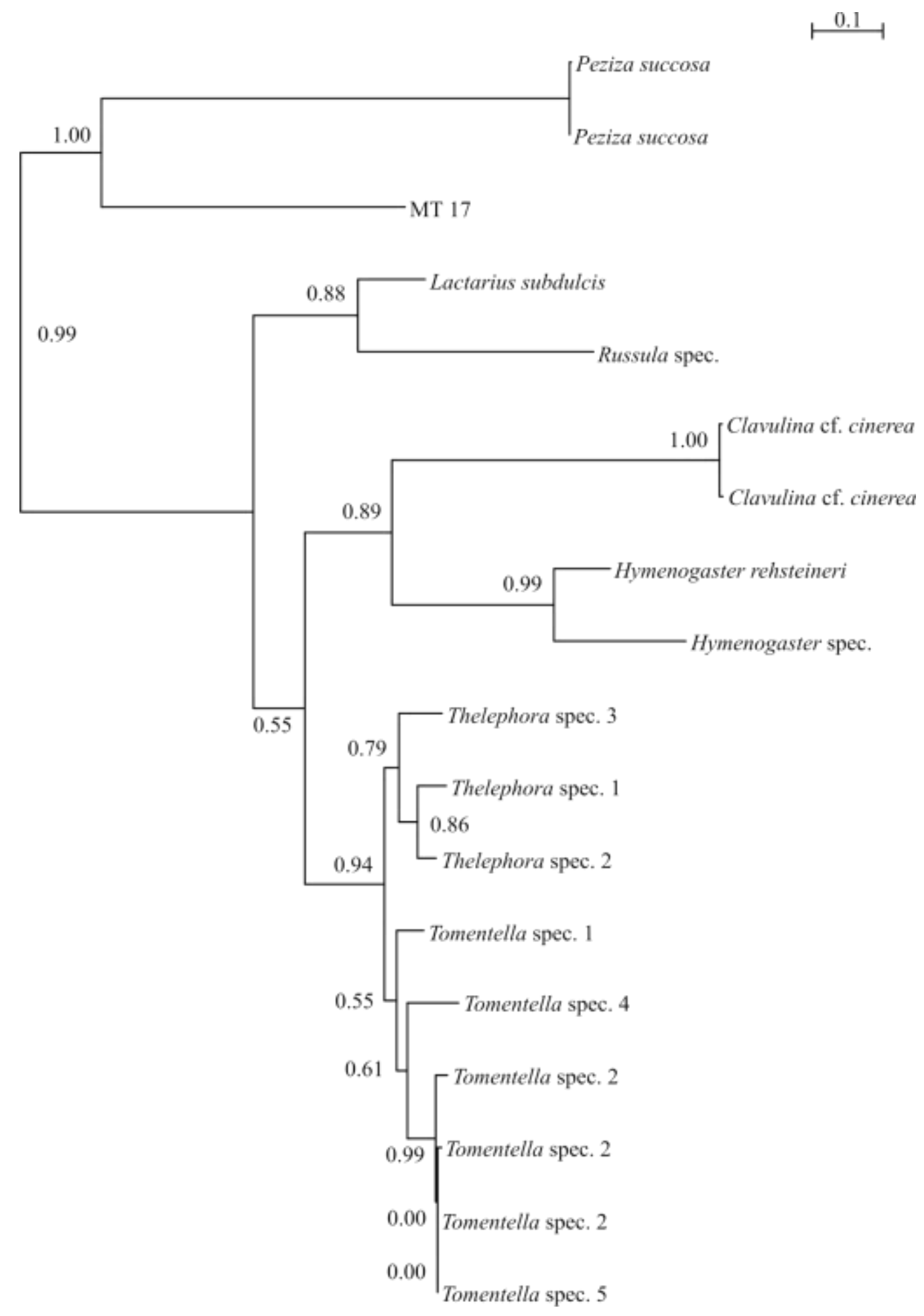




\section{General discussion}

5.1 Differential interactions between mycorrhizal fungi and tree species impact the structure and dynamics of plant communities

The present work demonstrates that interactions between ash and beech, in respect to nitrogen and phosphorus acquisition, were notably supported by mycorrhizal fungi. This resulted in a disadvantage for ash.

In mixed ash-beech forests, ash tends to dominate the belowground area with higher root biomass (Jacob et al. 2012, Rust \& Savill 2000). This thesis showed that despite the generally higher fine root biomass of ash, its $\mathrm{N}$ and $\mathrm{P}$ limitation increased in the presence of beech (Chapter 2 and 3). This was surprising, because ash has been reported to take up N (and P) more effectively than beech (Schulz et al. 2011). There are two possible explanations for the decreased growth and nutrient accumulation of ash in mixture with beech. Firstly, the results indicate that the interaction with beech affected nutrient accumulation of ash. The comparison of nutrient uptake efficiencies between tree species is usually based on measurements in monocultures (Comas et al. 2002, Schulz et al. 2011). However the conclusions based on plant functions measured in monocultures may not display the plant reactions in species mixtures.

Secondly, efficient nutrient retention and economical resource use might be more important plant characteristics in nutrient limited conditions than high nutrient uptake kinetics (Aerts 1999). The maintained N/P balance of beech leaves compared with an N/P inbalance of ash in the species mixture might therefore indicate that beech is better adapted to nutrient limitation than ash.

Our findings are important, since they suggest that despite the often higher root mass, ash cannot be interpreted as a belowground dominating tree species in mixture with beech. The relative competition index for $\mathrm{P}$ presented a convincing argument for the contrary.

The increased root biomass of beech in a dual-splitroot-rhizothron experiment indicates belowground overyielding, and thus, a possible biodiversity effect (Appendix 1). The previous studies of belowground diversity of tree species report both, positive (Schmid \& Kazda 2002) and neutral (Bolte \& Villanueva 2006, Leuschner et al. 2001, Meinen et al. 
2009) biodiversity effects on root growth. However, the role of tree species identity rather than biodiversity might predominate the effects (Jacob et al. 2012).

The differences in fungal species composition (Chapters 2, 3 and 5) might also change the strength of the plant interactions. This would also explain the different outcomes of studies on soil $\mathrm{N}$ form preferences for ash and beech (Dannenmann et al. 2009, Gessler et al. 1998, Schulz et al. 2011, Stadler et al. 1993).

No comparable biomass increase of beech, as found in dual-splitroot-rhizothron experiment, occurred in more nutrient limited system (Chapter 2 and 3). This result suggests that overyielding may be possible when resource limitation does not drive the tree species to competition. In fact, model based analysis of tree species diversity on temperate forest productivity indicate that environmental conditions influence productivity of mixed tree sites (Morin et al. 2011).

In addition, the differences in growth responses in our experiments could be explained by limited rooting area. In order to drive competition, the available soil volume was clearly restricted in chapters 2 and 3. Here, fine root density was on its upper limit in both

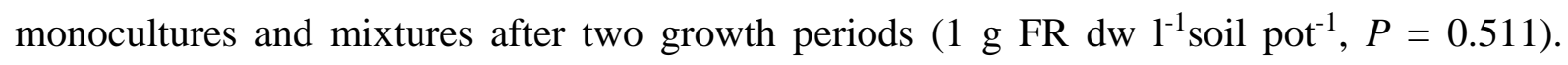
Similar upper fine root densities (1-2 $\mathrm{g}$ biomass $\mathrm{l}^{-1}$ ) have been reported in the topsoil horizons of temperate-broad leaved forests (Hertel 2011). This density appears to be exceeded neither in monocultures nor in mixed stands (Jacob et al. 2012). In contrast, in the split-root experiment the soil space compared to root mass was larger. This might partially explain the facilitative effect of ash on growth of beech, whereas growth of ash was unaffected by the presence of beech.

This thesis indicates that EM fungi contributed significantly to both $\mathrm{N}$ and $\mathrm{P}$ acquisition of beech. In addition, we demonstrated that EMs were substantially better accumulators for both, $\mathrm{N}$ and $\mathrm{P}$, than ash root tips (Chapter 2 and 3). Our findings reinforce earlier studies on dualmycorrhizal associations of single tree species, which have suggested that EM fungi are more efficient providers of P than AM fungi (Jones et al. 1998, van der Heijden 2001), but contrast the widely held view that AM fungi are more important for plant P nutrition than EM.

Although the biomass of extraradical hyphae of AM and EM fungi were not measured in this study, it is likely that EM rhizomorphs were more present in soil than extraradical hyphae of AM fungi (Chapter 2 and 3). This suggestion is supported by estimations of abundances of 
fungal species with different ecological lifestyles in soil (Bueé et al. 2009, Danielsen et al. 2012). Similar accumulation of $P$ in EM rhizomorphs and in EM root tips suggests that extraradical hyphae of EM were highly involved in beech nutrient uptake.

The distinction of extraradical hyphae of AM and EM species and their quantification are rather challenging. The currently available methods such as phospholipid fatty acid markers (PLFAs), content of ergosterol and quantification of ITS sequence copy numbers have only limited usability to differ between EM and AM types. We can therefore only speculate that a higher extent of extraradical EM hyphae may have lead to retention of nutrients in EM structures.

The differences in nutrient accumulation of EM species were taxon related (Chapters 2, 3 and 5). The most abundant beech root colonizing EM fungi, Tomentella castanea and Sebacina sp., were concurrently high accumulative species for both, $\mathrm{N}$ and $\mathrm{P}$ (Chapter 2 and 3). In contrast, $\mathrm{N}$ and $\mathrm{P}$ accumulation of Paxillus involutus was comparable with non-mycorrhizal root tips. This was surprising because this species has been reported to take up and translocate $\mathrm{N}$ to Fagus sylvatica (Finlay et al. 1989) and $\mathrm{P}$ to Pinus sylvestris (Bücking \& Heyser 2000). In previous studies, narrow niche-differentiation within lineages of EM species has been demonstrated (Geml et al. 2008). Therefore, relatively low $\mathrm{N}$ and $\mathrm{P}$ accumulation in the present experiments might indicate an unprofitable host-fungus association. Another explanation could be that the growth conditions were not suitable for $P$. involutus. Since host plants transfer more $\mathrm{C}$ to those fungal species that provide more nutrients (Corrêa et al. 2011, Corrêa \& Martins-Loução 2011, Kiers et al. 2011), unequal partitioning of carbon may have decreased the colonization of roots by less profitable EM species such as P. involutus.

Our data support that in a mixed ash-beech forest stand beech associated with EM community rather than ash with $\mathrm{AM}$ community has a competitive advantage in $\mathrm{P}$ and $\mathrm{N}$ acquisition. Highly nutrient accumulative EM species colonized up to $80 \%$ of mycorrhizal root tips of beech and were significantly involved in beech $\mathrm{N}$ and $\mathrm{P}$ acquisition. Given the high diversity in natural EM communities, complementarity of fungal species with respect to functional ecophysiological traits may promote coexistence of tree species (van der Heijden et al. 2003).

The results of the present study contributed new information about the role of different mycorrhizal fungi on plant competition for nutrients that so far has been lacking. In addition, the results of plant interactions between ash and beech on different soil nutrient availabilities could be applied to spatially explicit modelling of neighbor effects on forest dynamics. 


\subsection{Outlook}

Intepretations of the functional significance of mycorrhizal fungi on plant interactions are still limited by a lack of knowledge about functional capacities of most mycorrhizal fungi. In the present work, functional relevance of EM species on plant $\mathrm{N}$ and $\mathrm{P}$ uptake was demonstrated. Amongst others, a high accumulation of ${ }^{33} \mathrm{P}$ in EM rhizomorphs was shown. More definite conclusions about the role of AM and EM fungi on nutrient acquisition of ash and beech will be possible when future work includes quantitative measurements of extraradical mycelium in soil. This may explain whether EM fungi use the given soil volume more efficiently than AM fungi and restrict the amount of available nutrients for ash. Also the quantification of mycelial biomass of AM and EM could be conducted with real time PCR using AM and EM specific primers. In the near future, a large set of mycorrhizal genomes will be available for future research. At the moment whole genomes of Laccaria bicolour and Tuber melanosporum (Martin et al. 2008, Martin et al. 2010) already enable a primer design for regions coding for $\mathrm{N}$ and $\mathrm{P}$ transporter. A use of degenerative primers could allow a screening of a large set of root colonizing fungi for the presence of these genes. These could be used to detect functional differences of EM fungi during intra- and interspecific plant competition for $\mathrm{N}$ and $\mathrm{P}$.

EM diversity of beech roots increased in the presence of another beech (Appendix 1). This result indicates that a neighbouring tree with the same mycorrhizal type has a potential to increase the mycorrhizal community diversity and might enhance facilitation between tree individuals. Neighbour effects mediated by the mycorrhizal network need to be targeted by future research. As demonstrated in this work, stable and radioactive isotopes provide versatile, time-integrated measurements of nutrient and carbon fluxes. Future work could include pulse labelling of donator plant and measurements in proximate gainer plant to determine whether the nutrient and carbon fluxes occur only between trees with similar mycorrhizal types or are facilitative interactions possible also between fungi of different mycorrhizal types. 


\section{References}

Aerts, R. (1999), 'Interspecific competition in natural plant communities: mechanisms, tradeoffs and plant-soil feedbacks', Journal of Experimental Botany 50(330), 29-37.

Baldrian, P., Větrovský, T., Cajthaml, T., Dobiášová, P., Petránková, M., Šnajdr, J. \& Eichlerová, I. (2012), 'Estimation of fungal biomass in forest litter and soil', Fungal Ecology. In press. Online access 17.11.2012.

Buée, M., Reich, M., Murat, C., Morin, E., Nilsson, R. H., Uroz, S. \& Martin, F. (2009), ‘454 pyrosequencing analyses of forest soils reveal an unexpectedly high fungal diversity', New Phytologist 184(2), 449-456.

Bücking, H. \& Heyser, W. (2000), 'Subcellular compartmentation of elements in nonmycorrhizal and mycorrhizal roots of Pinus sylvestris: an X-ray microanalytical study. I. the distribution of phosphate', New Phytologist 145(2), 311-320.

Bolte, A. \& Villanueva, I. (2006), 'Interspecific competition impacts on the morphology and distribution of fine roots in European beech (Fagus sylvatica L.) and Norway spruce (Picea abies (L.) Karst.)', European Journal of Forest Research 125, 1526.

Cairney, J. (2011), 'Ectomycorrhizal fungi: the symbiotic route to the root for phosphorus in forest soils', Plant and Soil 344, 51-71.

Comas, Bouma \& Eissenstat (2002), 'Linking root traits to potential growth rate in six temperate tree species', Oecologia 132, 34-43.

Corrêa, A., Gurevitch, J., Martins-Loução, M. A. \& Cruz, C. (2012), 'C allocation to the fungus is not a cost to the plant in ectomycorrhizae', Oikos 121(3), 449-463.

Corrêa, A., Hampp, R., Magel, E. \& Martins-Loução, M.-A. (2011), 'Carbon allocation in ectomycorrhizal plants at limited and optimal $\mathrm{N}$ supply: an attempt at unraveling conflicting theories', Mycorrhiza 21, 35-51.

Corrêa, A. \& Martins-Loução, M.-A. (2011), C:N interactions and the cost:benefit balance in ectomycorrhizae, In: M. Rai \& A. Varma, (Eds), 'Diversity and Biotechnology of Ectomycorrhizae', Soil Biology 25, Springer Verlag, Berlin, 387-403.

Danielsen, L., Thürmer, A., Meinicke, P., Buée, M., Morin, E., Martin, F., Pilate, G., Daniel, R., Polle, A. \& Reich, M. (2012), 'Fungal soil communities in a young transgenic poplar plantation form a rich reservoir for fungal root communities', Ecology and Evolution 2(8), 1935-1948.

Dannenmann, M., Simon, J., Gasche, R., Holst, J., Naumann, P. S., Kögel-Knabner, I., Knicker, H., Mayer, H., Schloter, M., Pena, R., Polle, A., Rennenberg, H. \& Papen, H. (2009), 'Tree girdling provides insight on the role of labile carbon in 
nitrogen partitioning between soil microorganisms and adult European beech', Soil Biology and Biochemistry 41(8), 1622-1631.

Dybzinski, R., Fargione, J., Zak, D., Fornara, D. \& Tilman, D. (2008), 'Soil fertility increases with plant species diversity in a long-term biodiversity experiment', Oecologia 158, 85-93.

Finlay, R. D., H. EK, G. \& Soderstrom, B. (1989), 'Uptake, translocation and assimilation of nitrogen from ${ }^{15} \mathrm{~N}$-labelled ammonium and nitrate sources by intact ectomycorrhizal systems of Fagus sylvatica infected with Paxillus involutus', New Phytologist 113, 47-55.

Frostegård, S., Tunlid, A. \& Bååth, E. (2011), 'Use and misuse of PLFA measurements in soils', Soil Biology and Biochemistry 43(8), 1621-1625.

Geml, J., Tulloss, R. E., Laursen, G. A., Sazanova, N. A. \& Taylor, D. (2008), 'Evidence for strong inter- and intracontinental phylogeographic structure in Amanita muscaria, a wind-dispersed ectomycorrhizal basidiomycete', Molecular Phylogenetics and Evolution 48(2), 694-701.

Gessler, A., Schneider, S., von Sengbusch, D., Weber, P., Hanemann, U., Huber, C., Rothe, A., Kreuzer, K. \& Rennenberg, H. (1998), 'Field and laboratory experiments on net uptake of nitrate and ammonium by the roots of spruce (Picea abies) and beech (Fagus sylvatica) trees', New Phytologist 138(2), 275-285.

Hertel, D. (2011), 'Tree roots in canopy soils of old European beech trees - an ecological reassessment of a forgotten phenomenon', Pedobiologia 54(2), 119-125.

Jacob, A., Hertel, D. \& Leuschner, C. (2012), 'On the significance of belowground overyielding in temperate mixed forests: separating species identity and species diversity effects', Oikos pp. 1-11.

Jones, M. D., Durall, D. M. \& Tinker, P. B. (1998), 'A comparison of arbuscular and ectomycorrhizal Eucalyptus coccifera: growth response, phosphorus uptake efficiency and external hyphal production', New Phytologist 140, 125-134.

Kiers, E. T., Duhamel, M., Beesetty, Y., Mensah, J. A., Franken, O., Verbruggen, E., Fellbaum, C. R., Kowalchuk, G. A., Hart, M. M., Bago, A., Palmer, T. M., West, S. A., Vandenkoornhuyse, P., Jansa, J. \& Bücking, H. (2011), 'Reciprocal rewards stabilize cooperation in the mycorrhizal symbiosis', Science 333(6044), 880-882.

Leuschner, C., Hertel, D., Coners, H. \& Büttner, V. (2001), 'Root competition between beech and oak: a hypothesis', Oecologia 126, 276-284.

Martin, F., Aerts, A., Ahrén, D., Brun, A., Danchin, E. G. J., Duchaussoy, F., Gibon, J., Kohler, A., Lindquist, E., Pereda, V., Salamov, A., Shapiro, H. J., Wuyts, J., Blaudez, D., Buée, M., Brokstein, P., Canbäck, B., Cohen, D., Courty, P. E., 
Coutinho, P. M., Delaruelle, C., Detter, J. C., Deveau, A., DiFazio, S., Duplessis, S., Fraissinet-Tachet, L., Lucic, E., Frey-Klett, P., Fourrey, C., Feussner, I., Gay, G., Grimwood, J., Hoegger, P. J., Jain, P., Kilaru, S., Labbé, J., Lin, Y. C., Legué, V., Tacon, F. L., Marmeisse, R., Melayah, D., Montanini, B., Muratet, M., Nehls, U., Niculita-Hirzel, H., Oudot-Le Secq, M. P., Peter, M., Quesneville, H., Rajashekar, B., Reich, M., Rouhier, N., Schmutz, J., Yin, T., Chalot, M., Henrissat, B., Kües, U., Lucas, S., de Peer, Y. V., Podila, G. K., Polle, A., Pukkila, P. J., Richardson, P. M., Rouzé, P., Sanders, I. R., Stajich, J. E., Tunlid, A., Tuskan, G. \& Grigoriev, I. V. (2008), 'The genome of Laccaria bicolor provides insights into mycorrhizal symbiosis', Nature 452(7183), 88-92.

Martin, F., Kohler, A., Murat, C., Balestrini, R., Coutinho, P. M., Jaillon, O., Montanini, B., Morin, E., Noel, B., Percudani, R., Porcel, B., Rubini, A., Amicucci, A., Amselem, J., Anthouard, V., Arcioni, S., Artiguenave, F., Aury, J.-M., Ballario, P., Bolchi, A., Brenna, A., Brun, A., Buée, M., Cantarel, B., Chevalier, G., Couloux, A., Silva, C. D., Denoeud, F., Duplessis, S., Ghignone, S., Hilselberger, B., Iotti, M., Marçais, B., Mello, A., Miranda, M., Pacioni, G., Quesneville, H., Riccioni, C., Ruotolo, R., Splivallo, R., Stocchi, V., Tisserant, E., Viscomi, A. R., Zambonelli, A., Zampieri, E., Henrissat, B., Lebrun, M.-H., Paolocci, F., Bonfante, P., Ottonello, S. \& Wincker, P. (2010), 'Périgord black truffle genome uncovers evolutionary origins and mechanisms of symbiosis.', Nature 464(7291), 1033-1038.

Meinen, C., Hertel, D. \& Leuschner, C. (2009), 'Biomass and morphology of fine roots in temperate broad-leaved forests differing in tree species diversity: is there evidence of below-ground overyielding?', Oecologia 161(1), 99-111.

Morin, X., Fahse, L., Scherer-Lorenzen, M. \& Bugmann, H. (2011), 'Tree species richness promotes productivity in temperate forests through strong complementarity between species', Ecology Letters 14(12), 1211-1219.

Rust, S. \& Savill, P. (2000), 'The root systems of Fraxinus excelsior and Fagus sylvatica and their competitive relationships', Forestry 73(5), 499-508.

Schmid, I. \& Kazda, M. (2002), 'Root distribution of Norway spruce in monospecific and mixed stands on different soils', Forest Ecology and Management 159(1-2), $37-47$.

Schulz, H., Härtling, S. \& Stange, C. F. (2011), 'Species-specific differences in nitrogen uptake and utilization by six European tree species', Journal of Plant Nutrition and Soil Science 174(1), 28-37.

Stadler, J., Gebauer, G. \& Schulze, E.-D. (1993), 'The influence of ammonium on nitrate uptake and assimilation in 2-year-old ash and oak trees - a tracer-study with ${ }^{15} \mathrm{~N}$, Isotopenpraxis Isotopes in Environmental and Health Studies 29(1-2), 8592. 
Tilman, D., Wedin, D. \& Knops, J. (1996), 'Productivity and sustainability influenced by biodiversity in grassland ecosystems', Nature 379(6567), 718-720.

van der Heijden, E. W. (2001), 'Differential benefits of arbuscular mycorrhizal and ectomycorrhizal infection of Salix repens', Mycorrhiza 10(4), 185-193.

van der Heijden, M. G. A., Wiemken, A. \& Sanders, I. R. (2003), 'Different arbuscular mycorrhizal fungi alter coexistence and resource distribution between co-occurring plant', New Phytologist 157(3), 569-578. 


\section{Appendix 1}

Roots from beech (Fagus sylvatica L.) and ash (Fraxinus excelsior L.) differentially affect soil microorganisms and carbon dynamics

Simone Cesarz ${ }^{* a}$, Ann-Catrin Fender ${ }^{\mathrm{b}}$, Friderike Beyer ${ }^{\mathrm{b}}$, Kerttu Valtanen $^{\mathrm{c}}$, Birgit Pfeiffer ${ }^{\mathrm{d}}$ Dirk Gansert $^{\mathrm{b}}$, Dietrich Hertel ${ }^{\mathrm{b}}$, Andrea Polle ${ }^{\mathrm{c}}$, Rolf Daniel ${ }^{\mathrm{d}}$, Christoph Leuschner ${ }^{\mathrm{b}}$ and Stefan Scheu $^{\mathrm{a}}$

${ }^{a}$ J.F. Blumenbach Institute of Zoology and Anthropology, Georg August University Göttingen, Berliner Straße 28, 37073 Göttingen, Germany

${ }^{\mathrm{b}}$ Plant Ecology and Ecosystems Research, Georg August University Göttingen, Untere Karspüle 2, 37073 Göttingen, Germany

${ }^{\mathrm{c}}$ Department of Forest Botany and Tree Physiology, Georg August University Göttingen, Büsgenweg 2, 37077 Göttingen, Germany

${ }^{\mathrm{d}}$ Department of Genomic and Applied Microbiology, Institute of Microbiology and Genetics, Georg August University Göttingen,

Grisebachstr. 8, 37077 Göttingen, Germany

* Corresponding author: simone.cesarz@gmx.de, Telephone: 0049-551-397666 


\section{Highlights}

- Rhizodeposition of beech reduced soil $\mathrm{C}$ by decreasing $\mathrm{C}$ use efficiency of bacteria

- More litter-derived carbon is channeled into higher trophic levels in soil planted with ash

- Bacteria and fungi form different energy channels in soil planted with beech

- In particular the roots of beech alter $\mathrm{C}$ dynamics in soil 


\begin{abstract}
Knowledge on the influence of living roots on decomposition processes in soil is scarce but is needed to understand carbon dynamics in soil. We investigated the effect of dominant deciduous tree species of the Central European forest vegetation, European beech (Fagus sylvatica L.) and European ash (Fraxinus excelsior L.), on soil biota and carbon dynamics differentiating between root- and leaf litter-mediated effects. The influence of beech and ash saplings on carbon and nitrogen flow was investigated using leaf litter enriched in ${ }^{13} \mathrm{C}$ and ${ }^{15} \mathrm{~N}$ in double-split-root rhizotrons planted with beech and ash saplings as well as a mixture of both tree species and a control without plants. Stable isotope and compound-specific fatty acid analysis $\left({ }^{13} \mathrm{C}\right.$-PLFA) were used to follow the incorporation of stable isotopes into microorganisms, soil animals and plants. Further, the bacterial community composition was analyzed using pyrosequencing of $15 \mathrm{~S}$ rRNA gene amplicons. Although beech root biomass was significantly lower than that of ash only beech significantly decreased soil carbon and nitrogen concentrations after 475 days of incubation. In addition, beech significantly decreased microbial carbon use efficiency as indicated by higher specific respiration. Low soil $\mathrm{pH}$ probably increased specific respiration of bacteria and suggests that rhizodeposits of beech roots induced increased microbial respiration and therefore carbon loss from soil. Compared to beech, more litter carbon and nitrogen were channeled into higher trophic levels (Gamasida) in treatments with ash indicating higher amounts of litter-derived carbon to reach higher trophic levels under ash. Similar $\delta^{13} \mathrm{C}$ signatures of bacteria and fine roots indicate that mainly bacteria incorporated root-derived carbon in beech rhizotrons. The results suggest that beech and ash differentially impact soil processes with beech more strongly affecting the belowground system via root exudates and associated changes in rhizosphere microorganisms and carbon dynamics than ash.
\end{abstract}

Key words: ${ }^{13} \mathrm{C},{ }^{15} \mathrm{~N}$, bacteria, carbon cycling, decomposition, fungi, nitrogen, soil food web 


\section{Introduction}

Soils store twice as much carbon as plants and the atmosphere together thereby forming an important component of the global carbon cycle (Schlesinger and Andrews, 2000). However, the way carbon is processed and how carbon dynamics are controlled still is not well understood. Knowledge of controlling factors of the carbon flux from the entry into the soil until its release or sequestration is of significant importance, especially in face of global warming and climate disruption as a consequence of increased atmospheric $\mathrm{CO}_{2}(\mathrm{McKinley}$ et al., 2011).

In terrestrial ecosystems, $90 \%$ of the annual biomass produced by plants enters the dead organic matter pool forming the basis of the decomposer system in soil (Gessner et al., 2010). Plant carbon enters the soil via two pathways: dead organic matter (leaf litter and dead roots) and root exudates. Most studies suggest leaf litter quality as main factor explaining physical and chemical properties of soil systems, which in turn influence soil biota as drivers of decomposition processes (Reich et al., 2005; Jacob et al., 2009; Langenbruch et al., 2012). Litter quality strongly influences soil $\mathrm{pH}$ as calcium and magnesium of the litter compete with $\mathrm{H}^{+}$and $\mathrm{Al}^{3+}$ for exchange sites on soil particle surfaces or organic matter (Reich et al., 2005). As a consequence, high $\mathrm{pH}$ often promotes higher microbial biomass resulting in higher soil respiration, mineralization and decomposition (Swift et al., 1979; Wardle, 1998). Low mineralization and decomposition rates are associated with high $\mathrm{C}$-to- $\mathrm{N}$ ratios and high lignin contents as it is typical for recalcitrant litter. In contrast, Pollierer et al., (2007) highlighted that in temperate forests carbon does not enter the soil food web predominantly via litter but rather via roots. Rhizodeposits comprise labile exudates (e.g., sugars, amino acids and organic acids), but also complex molecules (e.g., polysaccharides, mucilage and proteins). Labile exudates control both community structure and activity of rhizosphere microorganisms (Paterson et al., 2009). Summarizing results of 95 plant ${ }^{14} \mathrm{C}$ labeling studies, Jones et al., (2004) estimated the loss of carbon by exudation to be equivalent to $5-10 \%$ of the net carbon fixed by plants and $25 \%$ of the carbon plants allocate to root growth. This supply of energy increases microbial biomass (Butler et al., 2004), acts as soil organic matter (SOM) priming agent (Bird et al., 2011) and alters the physical and chemical soil environment (Gregory, 2006). Microbial communities in rhizosphere and bulk soil are therefore responsible for root exudate-mediated changes in soil processes (Söderberg et al., 2004; Paterson et al., 2007). Since plant species differ in the quality and quantity of exudates (Jones et al., 2004), soil 
carbon dynamics are likely affected by plant species identity and diversity (Grayston et al., 1998; Steinbeiss et al., 2008).

Next to individual effects of distinct plant species (Jacob et al. 2009), decomposition studies showed positive mixing effects (Gartner and Cardon, 2004; Hättenschwiler et al., 2005). Until today, however, studies investigating the influence of plant diversity on belowground dynamics in forests are scare (but see Meinen et al., 2009) and most often only consider the effect of aboveground plant residues (Hättenschwiler and Gasser, 2005; Jacob et al., 2009, 2010). To what extent belowground processes mediated by roots and root exudates affect soil organisms and thereby carbon dynamics remains largely unknown. This lack of knowledge is unfortunate as $60 \%$ of the terrestrial carbon is bound in forests and its contribution to global carbon cycling is of fundamental importance (McKinley et al., 2011).

To improve knowledge on carbon dynamics in forest soils from a root perspective we used the common temperate broad-leaved tree species European beech (Fagus sylvatica L.) and European ash (Fraxinus excelsior L.) to differentiate between general and species-specific effects of living roots on soil organisms and decomposition of litter material in soil. Beech is the dominant tree species in many Central European deciduous forests. Ash often is associated with beech forests and is expected to increase in dominance in a warmer and drier climate (Broadmeadow and Ray, 2005). Life history traits of beech and ash differ strongly, e.g. speed of growth, root morphology, litter quality, mycorrhizal association, and nutrient, water and light use efficiency (Grime et al., 1997; Emborg, 1998). Beech has higher specific root tip abundance, specific fine root surface area (SRA) and specific fine root length (SRL), whereas ash roots are characterized by higher mean fine root diameter (Meinen et al., 2009). Roots of beech are colonized by ectomycorrhizal (EM) fungi and those of ash by arbuscular mycorrhizal (AM) fungi which differ in nutrient acquisition strategies (Smith and Read, 2008). Beech tolerates soil $\mathrm{pH}$ from acid to highly alkaline, while ash is restricted to soils of high base saturation (Weber-Blaschke et al., 2002). Litter of beech at more acidic sites has high $\mathrm{C}$-to-N ratio $>50$ and high lignin content, while ash litter is regarded as high quality litter due to its low C-to-N ratio of about 28 and low lignin content (Jacob et al., 2010).

For allowing access to the root system and to investigate interactions between both tree species, beech and ash saplings were planted into double split-root systems. The systems allowed dissecting root associated processes and belowground interactions between beech and ash. Carbon and nitrogen fluxes in soil were traced following the incorporation of ${ }^{13} \mathrm{C}$ and ${ }^{15} \mathrm{~N}$ 
from labelled ash litter into soil, bacteria, fungi, soil animals and plants. Ash litter was used to follow the uptake of resources from high quality litter materials by beech and ash as compared to more recalcitrant soil resources.

We hypothesized that (1) beech and ash differentially affect the structure of the microbial community thereby modifying soil processes and plant nutrient capture. Differences in microbial community structure are expected to (2) result in differential decomposition of labeled ash litter and differential mobilization of nutrients from the litter. Further, we expected (3) modifications of the soil microorganisms community and soil processes to be most pronounced in the mixed treatment with both tree species present due to a complementary effect on soil microorganisms and soil processes.

\section{Material and methods}

\subsection{Rhizotrons}

Double split-root rhizotrons were used to separate root systems of two tree saplings into compartments with root strands of one individual sapling at each side and a shared root compartment in the centre where root strands of both tree saplings could interact (Fig. 1). We focused on the middle compartment where the two root strands grew together. The central compartment had a volume of 7.61 and side compartments half the volume of 3.81 . Rhizotrons were $90 \mathrm{~cm}$ high and $64 \mathrm{~cm}$ wide, and were built from anodized aluminum covered at the front with a $10-\mathrm{mm}$ Perspex plate. They were tilted at $35^{\circ}$ to direct roots growing along the Perspex plate. The Perspex plate was covered with black scrim to ensure that roots grow in darkness. Rhizotrons were divided into six soil depth sections (I-VI). Every soil depth contained four manipulation sites (MS), two in the centre and two at the sides (Fig. 1). The back side of the rhizotrons was equipped with a cooling system keeping the temperature at a constant level of $20^{\circ} \mathrm{C}$ over the whole soil column. Climate conditions were set to $20^{\circ} \mathrm{C}$ air temperature, $70 \%$ relative air humidity and $10 \mathrm{~h}$ daylight in winter and $14 \mathrm{~h}$ in summer. 
(a)

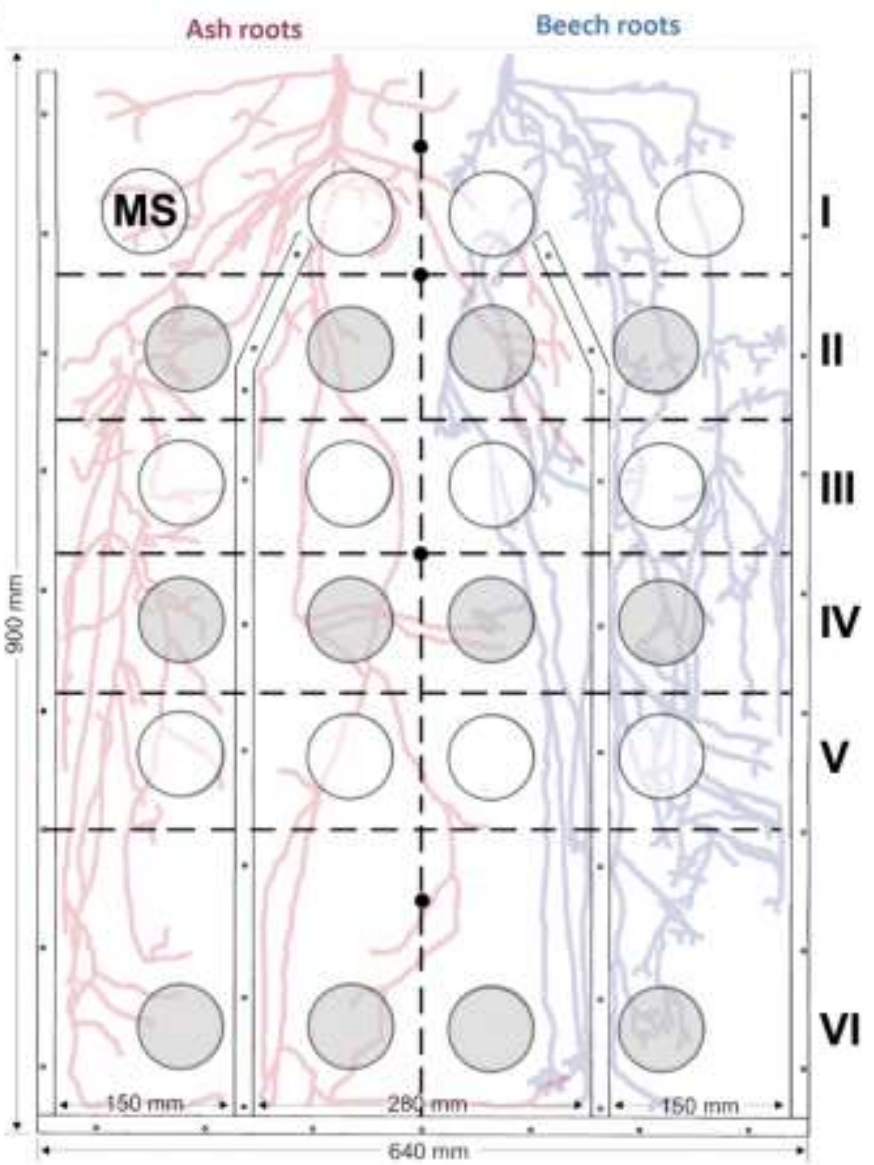

(b)

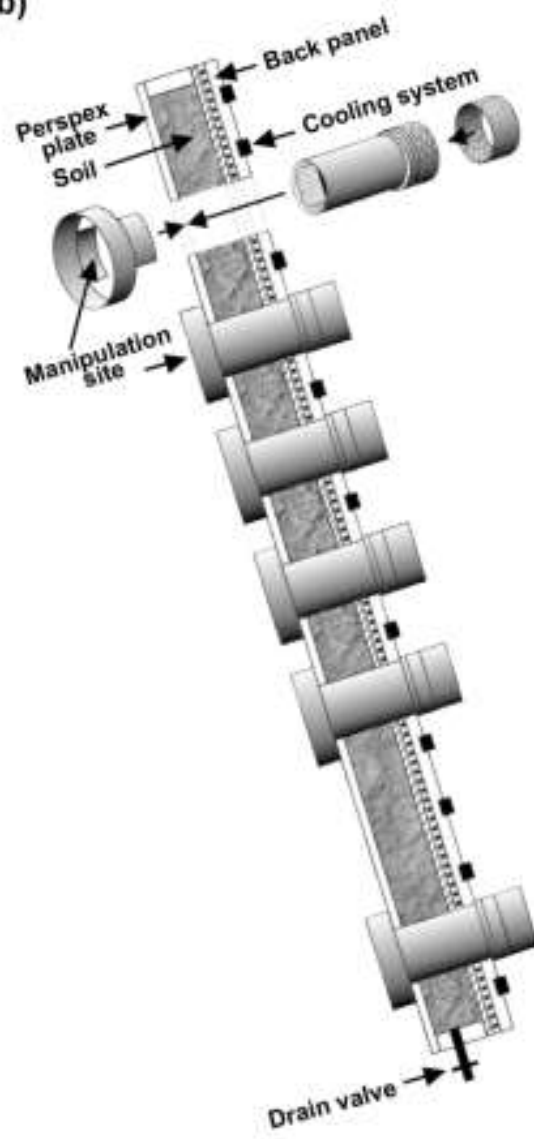

Fig 1 | Schematic setup of the double split-root rhizotrons. (a) Front view of mixed species treatments with ash (red) and beech (blue) roots interacting in the central compartment. Circles represent manipulation sites (MS) with soil (open circles) or a soil-litter mixture (shaded circles). Numbers indicate soil depths (I-VI). Black dots along central dashed line refer to the position of temperature sensors. Dashed lines mark the sampling raster in which soil samples were separated. (b) Side view of the double split-root rhizotron and assembly of the MS. Tubes inside the MS can be drawn completely to fill it with litter and soil. A cooling system is installed at the back panel and is flooded with distilled water. A valve allowed drainage of the rhizotrons.

The tree saplings were illuminated (EYE Lighting, Clean Ace, Mentor, OH, USA) ensuring a minimum PPFD of $200 \pm 10 \mu \mathrm{mol} \mathrm{m} \mathrm{m}^{-2}$ from June 2009 to October 2010. The experiment lasted for 475 days i.e., plants were harvested after the second season.

\subsubsection{Soil and plants}

The soil was taken from a mixed temperate broadleaf forest dominated by $F$. sylvatica, $F$. excelsior and Tilia cordata in Central Germany (Hainich forest, 51 ${ }^{\circ} 04^{\prime} \mathrm{N} 10^{\circ} 30^{\prime} \mathrm{E}$, about 350 $\mathrm{m}$ a.s.l) from a depth of $0-10 \mathrm{~cm}$ after removing the litter. The soil type was a Stagnic 
Table 1 Soil characteristics (means $\pm 1 \mathrm{SE}$ ) at the start of the experiment.

\begin{tabular}{|c|c|c|c|}
\hline Soil parameter & & & \\
\hline $\mathrm{pH}$ & 4.56 & \pm & 0.03 \\
\hline CEC $\left[\mu \mathrm{mol}_{\mathrm{c}} \mathrm{g}^{-1}\right.$ dry weight $]$ & 191.70 & \pm & 11.80 \\
\hline Base saturation [\%] & 22.90 & \pm & 1.30 \\
\hline $\mathrm{N}-\mathrm{NO}_{3}{ }^{-}\left[\mathrm{mg} \mathrm{kg}^{-1}\right.$ dry weight $]$ & 4.89 & \pm & 0.20 \\
\hline $\mathrm{N}-\mathrm{NH}_{4}{ }^{+}\left[\mathrm{mg} \mathrm{kg}^{-1}\right.$ dry weight $]$ & 6.00 & \pm & 0.22 \\
\hline $\mathrm{C}_{\text {org }}\left[\mathrm{g} \mathrm{kg}^{-1}\right.$ dry weight $]$ & 19.20 & \pm & 0.30 \\
\hline $\mathrm{N}_{\text {total }}\left[\mathrm{g} \mathrm{kg}^{-1}\right.$ dry weight] & 1.64 & \pm & 0.01 \\
\hline $\mathrm{C} / \mathrm{N}$ ratio $\left[\mathrm{g} \mathrm{g}^{-1}\right]$ & 11.70 & \pm & 0.14 \\
\hline $\mathrm{C}_{\text {mic }}\left[\mu \mathrm{g} \mathrm{C} \mathrm{g}^{-1}\right.$ dry weight $]$ & 382.80 & \pm & 14.60 \\
\hline
\end{tabular}

Luvisol (IUSS Working Group WRB 2007; 1.8\% sand, 80.2\% silt and 18.1\% clay) and free of carbonate $\left(<0.02 \%\right.$ of total carbon) with a $\mathrm{pH}\left(\mathrm{H}_{2} \mathrm{O}\right)$ of $4.56 \pm 0.03$ and a gravimetric water content at date of sampling of $22.7 \%$. Initial total carbon amounted to $19.2 \pm 0.3 \mathrm{~g} \mathrm{~kg}^{-1}$ dry weight, initial total nitrogen averaged $1.56 \pm 0.01 \mathrm{~g} \mathrm{~kg}^{-1}$ dry weight and base saturation was $22.9 \pm 1.3 \%$ (Table 1). Each rhizotron was filled with 15.21 of sieved soil $(1 \mathrm{~cm}$ mesh) containing natural microflora and soil fauna. Volumetric soil water content was monitored three times a week with a TDR measurement device (Trime-FM, IMKO, Ettlingen, Germany), and kept at constant level by adding distilled water. Soil temperature was measured with NTC thermistors (Epcos, Munich, Germany), arranged vertically in the centre of the rhizotrons, at soil depths of $8,20,42.5$ and $70.5 \mathrm{~cm}$ and in $2 \mathrm{~cm}$ distance of the Perspex plate. Data were recorded in 15-min intervals with a CR1000 data logger (combined with two AM416 Relay Multiplexer, Campbell Scientific Inc., Utah, USA).

In spring 2009, beech (F. sylvatica) and ash (F. excelsior) saplings with comparable root biomass were excavated in the Hainich forest with intact soil cores to preserve the root and $15.4 \pm 1.2 \mathrm{~cm}$ for beech and ash saplings, respectively. At the start of the experiment, ash had significantly higher fine root biomass than beech, but tree species did not differ significantly in total root and total aboveground biomass (Table 2). Before planting, the soil material adhering to the root systems was removed by watering. The remaining soil-water mixture was used to equilibrate microbial communities in soil. 
Table $2 \mid$ T-test table of $T$ - and $P$-values and means \pm 1 SE of plant biomass $\mathrm{g}^{-1}$ dry weight of beech and ash saplings at the start of the experiment $(n=5)$.

\section{Initial Biomass}

\section{Biomass}

Total

Total aboveground

Total belowground

Shoots

Leaves

Fine roots

Coarse roots

\begin{tabular}{|c|c|c|c|c|c|c|c|}
\hline$T$ & $P$ & \multicolumn{3}{|c|}{ Beech } & \multicolumn{3}{|c|}{ Ash } \\
\hline 0.15 & 0.7122 & 2.04 & - & 0.46 & 2.13 & \pm & 0.22 \\
\hline 0.01 & 0.9294 & 1.26 & \pm & 0.27 & 1.25 & \pm & 0.15 \\
\hline 0.81 & 0.3933 & 0.78 & \pm & 0.20 & 0.88 & \pm & 0.08 \\
\hline 0.27 & 0.6190 & 0.88 & \pm & 0.22 & 0.74 & \pm & 0.09 \\
\hline 2.49 & 0.1530 & 0.38 & \pm & 0.05 & 0.52 & \pm & 0.07 \\
\hline 6.49 & 0.0343 & 0.16 & \pm & 0.05 & 0.41 & \pm & 0.08 \\
\hline 0.08 & 0.7866 & 0.64 & \pm & 0.17 & 0.56 & \pm & 0.06 \\
\hline
\end{tabular}

Fifty-three days after planting, $1.5 \mathrm{~g}$ labelled ash litter was added into MS at every second soil depth (II, IV, VI; Fig. 1). Prior to adding ash leaves (air dried, crushed to pieces $<1 \mathrm{~cm}$ ) were mixed with $40 \mathrm{~g}$ soil (air dried). The litter was labelled with ${ }^{13} \mathrm{C}$ and ${ }^{15} \mathrm{~N}$ by incubating ash trees in a green house for one vegetation period with the $\mathrm{CO}_{2}$ concentration in air elevated by adding ${ }^{13} \mathrm{CO}_{2}(1,200 \mathrm{ppm})$ and by watering the soil with nutrient solution containing and 0.1 $\mathrm{mM}{ }^{15} \mathrm{NO}_{3}{ }^{15} \mathrm{NH}_{4}$ (both 99 atom \%; Euriso-top, Saint-Aubin, Essonne, France). Further, the solution contained $0.6 \mathrm{mM} \mathrm{CaCl}_{2}, 0.4 \mathrm{mM} \mathrm{MgSO}_{4}, 0.01 \mathrm{mM} \mathrm{FeCl}_{3}, 0.4 \mathrm{mM} \mathrm{K} 3 \mathrm{PO}_{4}, 1.8 \mu \mathrm{M}$ $\mathrm{MnSO}_{4}, 0.064 \mu \mathrm{M} \mathrm{CuCl}, 0.15 \mu \mathrm{M} \mathrm{ZnCl}_{2}, 0.1 \mu \mathrm{M} \mathrm{MoO}_{3}, 5 \mathrm{mM} \mathrm{NO}_{3} \mathrm{NH}_{4}$ and $0.01 \mathrm{mM}$ $\mathrm{H}_{3} \mathrm{BO}_{3}$, The stable isotope signature of the ash litter was $146.8 \pm 0.3 \%$ for $\delta^{13} \mathrm{C}$ and $13,139 \pm 59 \%$ for $\delta^{15} \mathrm{~N}$ (Table 3$)$.

\subsection{Experimental design}

The experiment was set up in a two-factorial design with the factors beech and ash (absence: “-“ and presence: "+”), resulting in the following treatments with four replicates each: (a) two beech saplings (BB), (b) two ash saplings (AA), (c) a mixture with one beech and one ash sapling (BA or $\mathrm{AB}$, depending on target tree species), and (d) an unplanted control (Co), resulting in rhizotrons without (B-: Co and $\mathrm{AA})$ and with beech $(\mathrm{B}+\mathrm{BB}$ and $\mathrm{BA})$, as well as rhizotrons without (A-: $\mathrm{Co}$ and $\mathrm{BB})$ and with ash $(\mathrm{A}+\mathrm{AA}$ and $\mathrm{AB})$. 


\subsection{Sampling}

After 475 days rhizotrons were harvested. They were opened in horizontal position and a sampling grid was used to identify locations for sampling i.e., at MS and the surrounding of these sites (SS) (Fig. 1). Samples from the depth layers II, III, IV and V of the central compartment were analyzed. Further, as we were not interested in effects of soil depth we pooled the data from the four layers. In addition to soil samples, plant shoots and roots from each of the soil layers were taken for measuring plant biomass.

Table 3 Isotopic signatures of the used soil, labeled ash litter and of the soil-litter-mixture in manipulation sites in rhizotrons at the start of the experiment and after 422 days (means $\pm 1 \mathrm{SE}$ ).

\begin{tabular}{|c|c|c|c|c|c|}
\hline & \multicolumn{3}{|c|}{ Start } & \multicolumn{2}{|c|}{ End } \\
\hline & Soil & Litter & $\begin{array}{c}\text { Soil-litter } \\
\text { mixture }\end{array}$ & $\begin{array}{l}\text { Soil-litter } \\
\text { mixture }\end{array}$ & $\begin{array}{c}\text { Difference } \\
*[\%]\end{array}$ \\
\hline$\delta^{13} \mathrm{C}[\% 0]$ & $-26.20 \pm 0.10$ & $146.80 \pm 0.32$ & $69.00 \pm 0.60$ & $-17.44 \pm 1.86$ & 88.25 \\
\hline$\delta^{15} \mathrm{~N}[\% 0]$ & $1.60 \pm 0.16$ & $13139.30 \pm 59.10$ & $6153.80 \pm 0.40$ & $577.38 \pm 124.88$ & 81.23 \\
\hline $\mathrm{C}[\%]$ & $1.92 \pm 0.03$ & $36.05 \pm 0.09$ & $5.93 \pm 0.05$ & $1.94 \pm 0.06$ & 65.34 \\
\hline $\mathbf{N}[\%]$ & $0.16 \pm 0.00$ & $1.85 \pm 0.01$ & $0.40 \pm 0.00$ & $0.18 \pm 0.004$ & 54.82 \\
\hline $\mathbf{C} / \mathbf{N}$ & $11.70 \pm 0.10$ & $19.50 \pm 0.10$ & $14.90 \pm 0.10$ & $10.98 \pm 0.12$ & 15.33 \\
\hline
\end{tabular}

\subsubsection{Plants}

At harvest shoot length and root collar diameter of saplings was measured. Roots were separated from soil, washed and cleaned from adhering soil particles. To obtain overall plant biomass fine root biomass estimated from MS for mycorrhizal analysis were combined with plant biomass data from SS. Whenever possible three intact root strands of ca. $7 \mathrm{~cm}$ length from each tree species per compartment and soil depths were taken and digitalised on a flatbed scanner for image analysis carried out using WinRhizo 2005c software (Régent Instruments Inc., Québec, QC, Canada) to determine specific fine root area (SRA; $\mathrm{cm}^{2} \mathrm{~g}^{-1}$ dry matter), specific fine root length (SRL; $\mathrm{cm} \mathrm{g}^{-1}$ dry matter) and total fine root surface. Thereafter, samples were oven-dried $\left(70^{\circ} \mathrm{C}, 48 \mathrm{~h}\right)$, weighed and milled for measurement of organic carbon $\left(\mathrm{C}_{\text {org }}\right)$, total nitrogen $\left(\mathrm{N}_{\text {total }}\right)$ as well as $\delta^{13} \mathrm{C}$ and $\delta^{15} \mathrm{~N}$ signatures (Delta $\mathrm{C}$, Finnigan MAT, Bremen, Germany). 


\subsubsection{Mycorrhiza}

Colonization of roots at MS by mycorrhiza-forming fungi was determined. Fine roots were stored in Falcon tubes with moist tissue paper at $4^{\circ} \mathrm{C}$ until analysis. Fine roots of beech were analyzed with a stereomicroscope (Leica M205 FA, Leica Microsystems, Wetzlar, Germany). The percentage of EM fungi colonization was calculated using the following equation:

EM fungi colonization $[\%]=\left(\frac{n \text { mycorrhizal root tips }}{n \text { vital root tips }}\right) \times 100$

Fine roots of ash were stored in $70 \% \mathrm{EtOH}$ at room temperature. For determining the colonization by AM fungi roots were stained with lactophenole-blue (Schmitz et al., 1991) and stored at room temperature in 50\% glycerol until microscopic inspection at 200x magnification. AM fungi colonization was calculated with the magnified intersection method of McGonigle et al., (1990) using a 10x10 grid. The abundance of vesicles, arbuscles and hyphae was calculated as percentage of mycorrhizal structures of the total number of intersections. The percentage of vesicles was taken as relative colonization rate of AM fungi and used for further calculations.

\subsubsection{Soil properties}

Soil $\mathrm{pH}$ was measured in a suspension of $10 \mathrm{~g}$ soil and $25 \mathrm{ml} \mathrm{H}_{2} \mathrm{O}$ with a Vario $\mathrm{pH}$ meter (WTW GmbH, Weilheim, Germany). Soil water content was measured gravimetrically after drying at $105^{\circ} \mathrm{C}$ for $24 \mathrm{~h}$. Nitrate and ammonium concentrations were measured by extracting soil samples in $0.5 \mathrm{M} \mathrm{K}_{2} \mathrm{SO}_{4}$ solution (1:3 wet soil mass-to-solution ratio). Samples were shaken for $1 \mathrm{~h}$ and filtered through Sartorius folded filters (Sartorius Stedim, Aubagne, France). Nitrate and ammonium concentrations of filtered extracts were analyzed using continuous flow injection colorimetry $\left(\mathrm{SAN}^{+}\right.$Continuous Flow Analyzer, Skalar Instruments, Breda, The Netherlands). Nitrate was determined by copper cadmium reduction method (ISO method 13395) and ammonium was quantified by Berthelot reaction method (ISO method 11732). $\mathrm{C}_{\text {org }}, \mathrm{N}_{\text {total }}$ as well as $\delta^{13} \mathrm{C}$ and $\delta^{15} \mathrm{~N}$ values were measured after grinding soil samples with a disc mill. Samples were analyzed with a coupled system consisting of an elemental analyzer (NA 1500, Carlo Erba, Mailand) and a mass spectrometer (Delta C, Finnigan MAT, Bremen, Germany). 


\subsubsection{Microbial respiration}

Basal respiration (BAS), microbial biomass $\left(\mathrm{C}_{\text {mic }}\right)$, and specific respiration $\left(q \mathrm{O}_{2}\right)$ were measured by substrate-induced respiration (SIR) i.e., the respiratory response of microorganisms to glucose (Anderson and Domsch, 1978). Before measurement, roots were removed and soil samples were sieved $(2 \mathrm{~mm})$. Measurements were done using an automated $\mathrm{O}_{2}$ microcompensation system (Scheu, 1992). BAS of microorganisms reflected their averaged oxygen consumption rate without the addition of glucose within 10-30 h after attachment of the samples to the analysis system. Subsequently, $4 \mathrm{mg}$ glucose $\mathrm{g}^{-1}$ soil dry weight was added as aqueous solution to the soil samples. The mean of the three lowest hourly measurements within the first $10 \mathrm{~h}$ was taken as the maximum initial respiratory

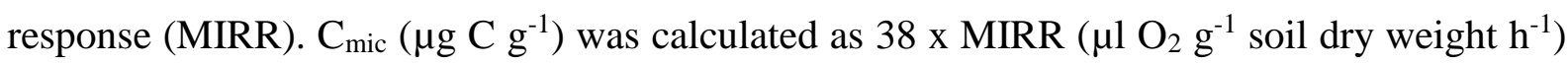
according to Beck et al., (1997). Microbial specific respiration $q \mathrm{O}_{2}\left(\mu 1 \mathrm{O}_{2} \mathrm{mg}^{-1} \mathrm{C}_{\mathrm{mic}} \mathrm{h}^{-1}\right)$ was calculated as BAS/ $\mathrm{C}_{\text {mic }}$.

\subsubsection{Fatty acid analysis}

Before extraction of lipids, soil samples were sieved $(2 \mathrm{~mm})$ and root and litter pieces were removed. Lipid extraction followed Frostegård et al., (1991). Briefly, 4 g soil (wet weight) was mixed with $18.5 \mathrm{ml}$ Bligh \& Dyer solution and shaken for $2 \mathrm{~h}$ (Bligh and Dyer, 1959). Subsequently, samples were centrifuged at $2,500 \mathrm{rpm}$ for $10 \mathrm{~min}$ at $8^{\circ} \mathrm{C}$. Supernatants were transferred to new tubes. The remaining pellet was washed with $5 \mathrm{ml}$ of the Bligh \& Dyer solution and centrifuged as described above. The supernatants were combined and $6.2 \mathrm{ml}$ chloroform and $6.2 \mathrm{ml}$ citrate buffer were added. Two $\mathrm{ml}$ of the lipid containing lower phase was transferred to a new tube. The organic phase was evaporated at $40^{\circ} \mathrm{C}$ for $40 \mathrm{~min}$. Columns containing silic acid fractionated the lipid material into phospholipids by adding methanol. The phospholipid-methanol solution was evaporated at $40^{\circ} \mathrm{C}$ for $90 \mathrm{~min}$. Each sample was dissolved in $1 \mathrm{ml}$ methanol-toluene-solvent (1:1) and $30 \mu \mathrm{l}$ internal Standard (5.77 mg methylnondecanoat in $25 \mathrm{ml}$ isooctane) was added. Basic methanolysis of lipids was conducted in $1 \mathrm{ml} 0.2 \mathrm{M}$ methanolic $\mathrm{KOH}\left(2.8 \mathrm{~g} \mathrm{KOH}\right.$ in $250 \mathrm{ml}$ methanol) incubated at $37^{\circ} \mathrm{C}$ for $15 \mathrm{~min}$. Afterwards, $2 \mathrm{ml}$ hexane, $0.3 \mathrm{ml}$ acetic acid and $2 \mathrm{ml}$ deionized water were added, vortexed and centrifuged as described above. The upper phase was transferred to new tubes and evaporated at $40^{\circ} \mathrm{C}$ for $45 \mathrm{~min}$. The remaining extract was solved with $100 \mu \mathrm{l}$ isooctane and filled into $1.5 \mathrm{ml}$ vials for analysis. Bacterial biomass was estimated using the following

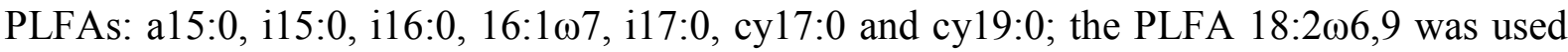


as fungal biomarker (Ruess and Chamberlain, 2010). A gas-chromatography-combustionisotope-ratio-monitoring-mass spectrometer (GC-C-IRM-MS) using Thermo Finnigan Trace GC coupled via a GP interface to a Delta Plus mass spectrometer (Finnigan, Bremen, Germany) was used to determine the isotopic composition of individual PLFAs. Fatty acid identification was verified by GC-MS using a Varian CP-3800 chromatograph coupled to a 1200L mass spectrometer and a fused silica column (Phenomenex Zebron ZB-5MS, $30 \mathrm{~m}$, $0.25 \mu \mathrm{m}$ film thickness, ID $0.32 \mathrm{~mm}$ ) and helium as carrier gas.

\subsubsection{Pyrosequencing}

DNA and RNA were co-isolated from $2 \mathrm{~g}$ soil using the RNA PowerSoil ${ }^{\mathrm{TM}}$ Total RNA Isolation Kit and DNA Elution Accessory Kit (MO BIO Laboratories Inc., Carlsbad, CA, USA). Residual DNA contaminations in RNA extracts were removed using the TURBO DNA-free $e^{\mathrm{TM}}$ Kit (Ambion Applied Biosystems, Darmstadt, Germany). RNA was concentrated using the RNeasy MiniElute Kit (QIAGEN, Hilden, Germany). The nucleic acid concentration was estimated using a NanoDrop ND-1000 spectrophotometer (Peqlab Biotechnologie GmbH, Erlangen, Germany).

The V2-V3 region of the $16 \mathrm{~S}$ rRNA was reverse transcribed using the SuperScript ${ }^{\mathrm{TM}}$ III reverse transcriptase (Invitrogen, Karlsruhe, Germany). As template 100 ng of the DNA-free RNA were applied. The resulting cDNA as well as the extracted DNA was amplified in triplicate using the Phusion ${ }^{\circledR}$ Hot Start High-Fidelity DNA polymerase (FINNZYMES, Espoo, Finland) as described by Nacke et al., (2011).

The following barcoded primer set was used for reverse transcription and amplification, containing the Roche 454 pyrosequencing adaptors (underlined): V2for 5'CTATGCGCCTTGCCAGCCCGCTCAGAGTGGCGGACGGGTGAGTAA-3' and V3rev 5'-CGTATCGCCTCCCTCGCGCCATCAGCGTATTACCGCGGCTGCTG-3'

modified from (Schmalenberger et al., 2001).

The PCR products were treated and purified as described by Nacke et al., (2011). All kits were used as described in the manufacturer's instructions. The Göttingen Genomics Laboratory determined the sequences of the partial 16S rRNA genes using a Roche GS-FLX 454 pyrosequencer (Roche, Mannheim, Germany) according to the manufacturer's instructions for amplicon sequencing. Sequences shorter than $300 \mathrm{bp}$ were removed from the dataset. 
To minimize the bias introduced by pyrosequencing due to decreasing read precision at the end of the reads denoising was carried out using Denoiser 0.91 (Reeder and Knight, 2010). OTU determination was performed using uclust OTU picker 1.2.22q (Edgar, 2010) at genetic divergence of 3\%, 5\% and 20\% according to Schloss and Handelsman (2005). The resulting datasets have been deposited in the GenBank short-read archive under accession number SRA050002.

\subsubsection{Soil animals}

Soil not needed for other analysis was taken to extract soil animals by heat (Kempson et al., 1963). Animals were conserved in saturated $\mathrm{NaCl}$ solution and kept at $-10^{\circ} \mathrm{C}$ until analysis. The gamasid mite Hypoaspis aculeifer (G. Canestrini, 1884) was taken for stable isotope analysis as it occurred in sufficient numbers for the analysis. Twenty adult mites were weighed into tin capsules and dried at $40^{\circ} \mathrm{C}$ for $24 \mathrm{~h}$. Samples were analyzed as described above.

\subsection{Statistical analysis}

Two-way ANOVA was used to test for main effects of beech (B- and B+), ash (A- and A+) and their interactions with data of the four soil depths pooled. To detect differences in plant biomass and mycorrhizal colonization contrasts were calculated using pairwise $t$-test to account for dependence in mixed rhizotrons. U-Test was used for analyzing the number of root tips. Treatments in beech-only rhizotrons (BB) were compared to ash-only (AA) and beech-ash mixture (BA). Ash (AA) was also compared with beech-ash mixture (AB). Statistical analyzes were done using SAS 9.2 (SAS Institute; Cary, NC, USA).

Discriminant function analysis (DFA) was calculated to analyze fatty acid patterns combined with microbial respiration and soil chemical data. Differences of the bacterial composition in beech and ash rhizotrons and the control were calculated using multi-dimensional scaling (MDS) to reduce dimensions in the dataset. DFA and MDS were calculated using STATISTICA 7.0 for Windows (StatSoft, Tulsa, USA, 2001).

Means were compared using Tukey's Honestly Significant Difference test $(P<0.05)$. Data were log- or arcsine-square root transformed (percentages) to improve homogeneity of variance. Means given in text and tables are based on non-transformed data. 


\section{Results}

\subsection{Plants and mycorrhizae}

After 475 days, total biomass of tree saplings in BB rhizotrons was significantly lower than in $\mathrm{AA}$ and BA rhizotrons (Table 4). Fine and coarse root biomass were significantly lower in BB rhizotrons compared to that of saplings in AA (-69\%) and BA rhizotrons (-62\%) resulting in significantly lower total root biomass. Total biomass, total root biomass and coarse root biomass of saplings in mixtures exceeded that of saplings in monocultures, but this increase was only significant for beech $(60 \%, 62 \%, 70 \%$, respectively); biomass of ash saplings in mixture increased by $11 \%, 17 \%$ and $23 \%$, respectively.

$\delta^{13} \mathrm{C}$ and $\delta^{15} \mathrm{~N}$ signatures in fine roots were significantly lower in $\mathrm{BB}$ than those in $\mathrm{AA}$ rhizotrons (Table 4). SRA and SRL did not differ significantly between tree species but tended to be higher in beech (BB vs $\mathrm{AA}:+6 \%$ and $+68 \%$, respectively), especially in the mixture (BA vs AB: $+24 \%$ and $79 \%$, respectively. Generally, fine root tips of tree saplings increased in mixed rhizotrons, especially beech in mixed rhizotrons had a significantly higher number of root tips than beech in monoculture by $+89 \%$ compared to ash in mixed rhizotrons and ash in monoculture by $+54 \%$. Mycorrhizal colonization of roots of beech in BB rhizotrons was significantly lower than that of roots of ash in AA rhizotrons, however, as beech and ash are colonized by different types of mycorrhiza the differences have to be interpreted with caution. Beech did not influence the colonization rate of ash by arbuscular mycorrhiza ( $\mathrm{AA}$ vs $\mathrm{AB} ;+2 \%$ ), whereas ash increased the colonization of beech by ectomycorrhiza (BB vs BA; + $45 \%$ ) although the effect was not significant (Table 4).

\subsection{Soil properties}

In general, the studied soil properties were strongly affected by beech and not by ash with interactions between tree species also being not significant (Table 5). Soil $\mathrm{pH}$ was significantly lower in $\mathrm{B}+(4.54 \pm 0.08)$ than in $\mathrm{B}$ - rhizotrons $(4.80 \pm 0.06)$. In presence of beech $\mathrm{C}_{\text {org }}$ and $\mathrm{N}_{\text {total }}$ were significantly decreased by $-7 \%$ and $-6 \%$, respectively, but $\mathrm{NO}_{3}{ }^{-}$and $\mathrm{NH}_{4}{ }^{+}$concentrations remained unaffected. Further, $\delta^{13} \mathrm{C}$ and $\delta^{15} \mathrm{~N}$ of bulk soil were significantly lower in $\mathrm{B}+(-24.46 \pm 0.32 \%$ and $127.04 \pm 19.95 \%$, respectively) compared to B- rhizotrons (-22.24 $\pm 0.78 \%$ and $265.25 \pm 48.79 \%$, respectively). Generally, after 422 days of litter incubation, the signatures of $\delta^{13} \mathrm{C}$ and $\delta^{15} \mathrm{~N}$ within the soil-litter-mixtures decreased strongly by $88 \%$ and $81 \%$ respectively (Table 3 ). 


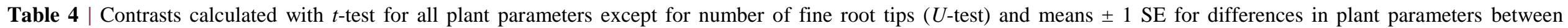
individual trees in rhizotrons after 475 days.

\begin{tabular}{|c|c|c|c|c|c|c|c|c|c|c|c|c|c|c|c|c|c|c|}
\hline \multirow[b]{3}{*}{ Biomass [g dry weight] plan } & \multicolumn{2}{|c|}{$\begin{array}{l}\text { Pure beech } \\
\text { (BB) vs. } \\
\text { pure ash } \\
\text { (AA) }\end{array}$} & \multicolumn{2}{|c|}{$\begin{array}{c}\text { Pure beech } \\
\text { (BB) vs. } \\
\text { beech in } \\
\text { mixture (BA) }\end{array}$} & \multicolumn{2}{|c|}{$\begin{array}{c}\text { Pure ash } \\
\text { (AA) vs. } \\
\text { ash in } \\
\text { mixture (AB) }\end{array}$} & \multirow{2}{*}{\multicolumn{3}{|c|}{ BB }} & \multirow{2}{*}{\multicolumn{3}{|c|}{$\mathbf{A A}$}} & \multirow{2}{*}{\multicolumn{3}{|c|}{ BA }} & \multirow{2}{*}{\multicolumn{3}{|c|}{$\mathbf{A B}$}} \\
\hline & \multirow{2}{*}{$t$} & \multirow[t]{2}{*}{$\boldsymbol{P}$} & \multirow[t]{2}{*}{$t$} & \multirow[t]{2}{*}{$P$} & \multirow[t]{2}{*}{$t$} & \multirow[t]{2}{*}{$P$} & & & & & & & & & & & & \\
\hline & & & & & & & & & & & & & & & & & & \\
\hline Total & 8.82 & 0.0117 & 6.39 & 0.0266 & 0.00 & 0.9518 & 4.52 & \pm & 0.79 & 12.08 & \pm & 1.69 & 11.33 & \pm & 2.03 & 13.50 & \pm & 2.33 \\
\hline Total aboveground & 4.20 & 0.0629 & 2.91 & 0.1138 & 1.11 & 0.3128 & 1.85 & \pm & 0.38 & 3.34 & \pm & 0.86 & 4.29 & \pm & 1.01 & 3.03 & \pm & 0.43 \\
\hline Total root & 9.52 & 0.0094 & 6.96 & 0.0217 & 0.28 & 0.6035 & 2.67 & \pm & 0.50 & 8.74 & \pm & 1.08 & 7.04 & \pm & 1.08 & 10.47 & \pm & 2.15 \\
\hline Shoot & 1.24 & 0.2876 & 3.43 & 0.0889 & 0.12 & 0.7300 & 1.38 & \pm & 0.25 & 1.78 & \pm & 0.32 & 3.20 & \pm & 0.73 & 2.64 & \pm & 0.41 \\
\hline Leaves & 5.14 & 0.0426 & 0.53 & 0.4809 & 7.50 & 0.0180 & 0.46 & \pm & 0.14 & 1.56 & \pm & 0.56 & 1.08 & \pm & 0.34 & 0.39 & \pm & 0.22 \\
\hline Fine roots & 9.14 & 0.0106 & 4.60 & 0.0532 & 0.09 & 0.7669 & 0.78 & \pm & 0.18 & 2.38 & \pm & 0.30 & 1.80 & \pm & 0.27 & 2.27 & \pm & 0.44 \\
\hline \multirow{2}{*}{\multicolumn{19}{|c|}{$\delta^{13} \mathrm{C}[\% \%]$ Plant fractions }} \\
\hline & & & & & & & & & & & & & & & & & & \\
\hline Shoot & 5.14 & 0.0426 & 7.00 & 0.0214 & 2.12 & 0.1708 & -29.09 & \pm & 0.32 & -28.07 & \pm & 0.28 & -27.90 & \pm & 0.22 & -27.40 & \pm & 0.26 \\
\hline Leave & 0.30 & 0.5955 & 0.25 & 0.6287 & 0.75 & 0.4029 & -29.62 & \pm & 0.56 & -29.26 & \pm & 0.27 & -29.29 & \pm & 0.44 & -29.83 & \pm & 0.20 \\
\hline Fine roots & 8.27 & 0.0139 & 0.04 & 0.8402 & 0.01 & 0.9395 & -27.64 & \pm & 0.34 & -25.60 & \pm & 0.85 & -27.49 & \pm & 0.19 & -25.56 & \pm & 0.23 \\
\hline Coarse roots & 12.86 & 0.0037 & 2.78 & 0.1215 & 0.06 & 0.8162 & -28.35 & \pm & 0.31 & -25.74 & \pm & 0.76 & -27.15 & \pm & 0.31 & -25.92 & \pm & 0.32 \\
\hline \multicolumn{19}{|c|}{$\delta^{15} \mathbf{N}$ [\%o] Plant fractions } \\
\hline Shoot & 0.87 & 0.3701 & 0.07 & 0.8018 & 2.15 & 0.1682 & 171.27 & \pm & 30.67 & 260.05 & \pm & 66.16 & 154.54 & \pm & 18.34 & 154.40 & \pm & 26.76 \\
\hline Leaves & 5.34 & 0.0394 & 0.55 & 0.4741 & 1.98 & 0.1853 & 192.42 & \pm & 32.67 & 316.50 & \pm & 43.37 & 166.67 & \pm & 23.49 & 228.28 & \pm & 15.10 \\
\hline Fine roots & 4.77 & 0.0496 & 1.35 & 0.2674 & 4.07 & 0.0666 & 209.02 & \pm & 41.75 & 396.07 & \pm & 99.34 & 148.85 & \pm & 17.63 & 214.48 & \pm & 22.80 \\
\hline Coarse roots & 9.34 & 0.0100 & 0.10 & 0.7630 & 2.81 & 0.1196 & 193.66 & \pm & 27.78 & 390.78 & \pm & 78.87 & 178.50 & \pm & 12.60 & 257.86 & \pm & 19.23 \\
\hline \multicolumn{19}{|l|}{ SRA $\left[\mathrm{cm}^{2} \mathbf{g}^{-1}\right]$} \\
\hline Fine roots & 0.23 & 0.6385 & 0.05 & 0.8271 & 0.78 & 0.3950 & 485.16 & \pm & 15.36 & 456.49 & \pm & 42.70 & 509.00 & \pm & 54.07 & 410.65 & \pm & 64.00 \\
\hline \multicolumn{19}{|l|}{ SRL $\left[\mathrm{cm} \mathrm{g}^{-1}\right]$} \\
\hline Fine roots & 2.89 & 0.1150 & 0.50 & 0.4947 & 0.20 & 0.6596 & 2374.80 & \pm & 221.17 & 1414.42 & \pm & 168.82 & 3235.44 & \pm & 848.14 & 1810.83 & \pm & 450.85 \\
\hline \multicolumn{19}{|l|}{ Fine root tips } \\
\hline $\begin{array}{c}\text { Total number } \\
\text { Mycorrhiza [\%] }\end{array}$ & -0.48 & 0.9970 & -13.16 & 0.00010 & 2.13 & 0.1750 & 1623.50 & \pm & 230.01 & 2299.00 & \pm & 419.58 & 3072.50 & \pm & 207.37 & 3543.75 & \pm & 107.79 \\
\hline Colonization rate & 27.50 & 0.0002 & 3.07 & 0.1053 & 0.04 & 0.8481 & 37.81 & \pm & 8.58 & 81.82 & \pm & 5.17 & 54.80 & \pm & 6.51 & 83.54 & \pm & 2.87 \\
\hline
\end{tabular}


Table 5 | ANOVA table of $F$ - and $P$-values on the effects of beech and ash and interactions between both tree species in rhizotrons as well as means \pm 1 SE.

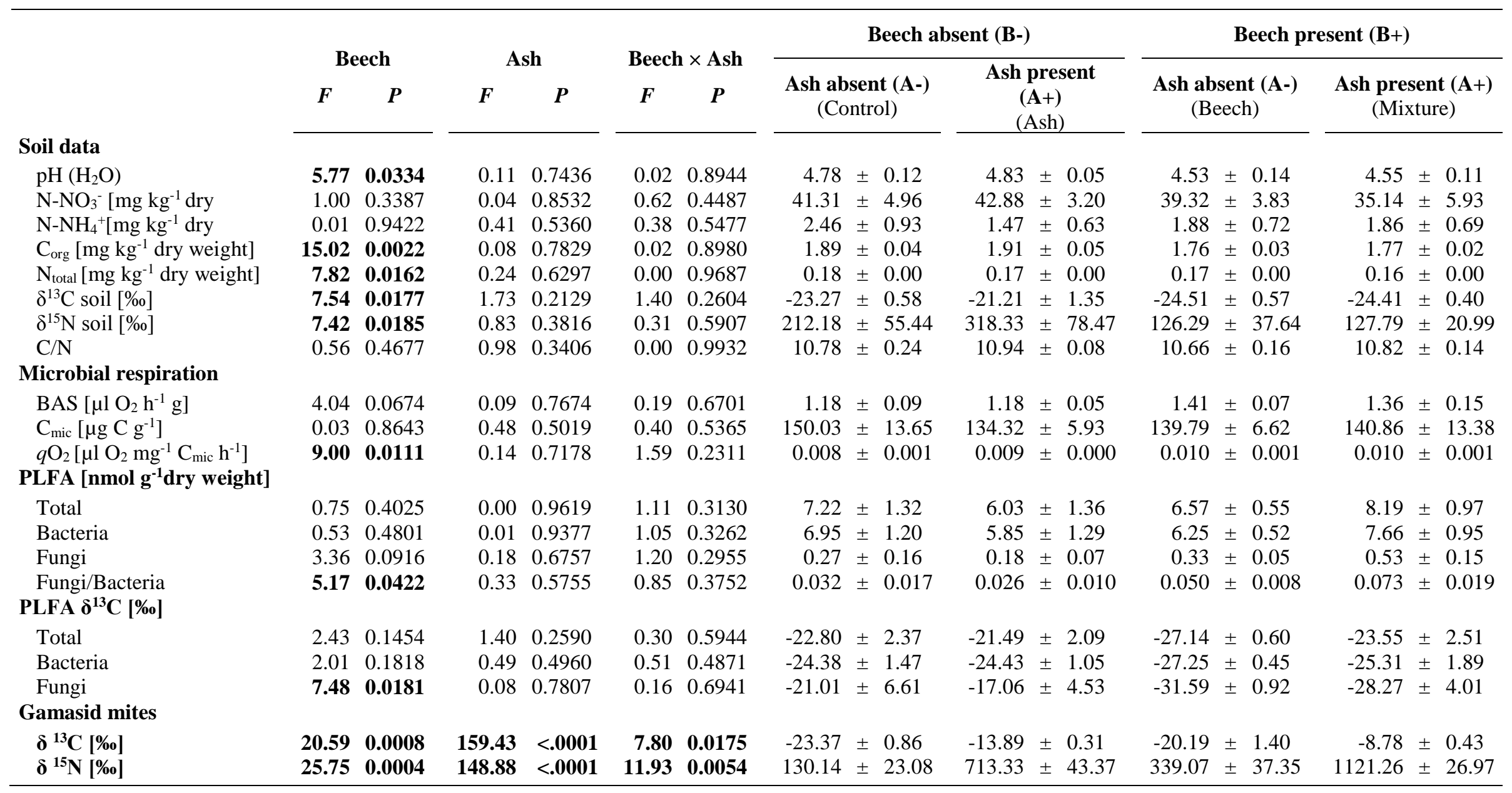




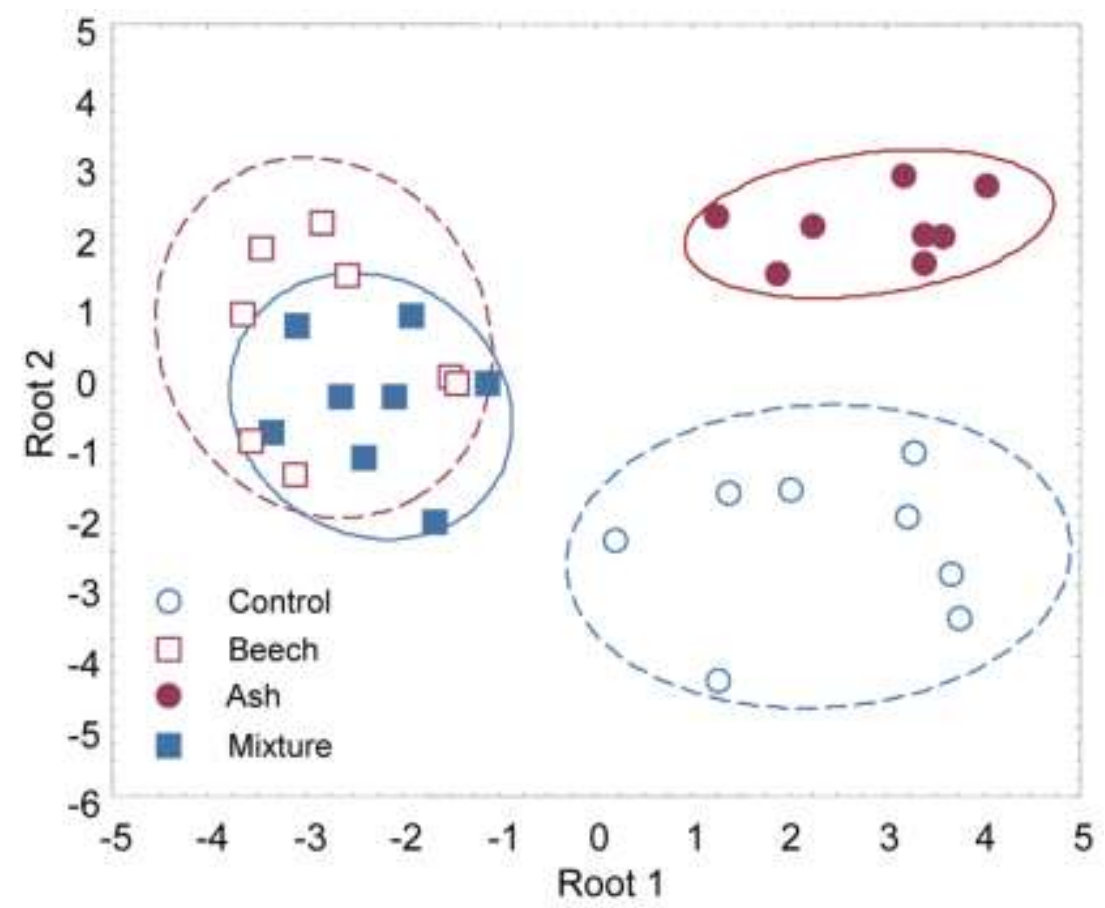

Fig 2 Discriminant functional analysis (DFA) of microbial PLFAs, microbial respiration and soil properties in rhizotrons without trees (control), beech saplings, ash saplings and a mixture of both tree species. Wilks' Lambda: $0.016480, \mathrm{~F}(54,33)=1.85, P=0.0296$. Ellipses represent confidence intervals at $P=0.05$.

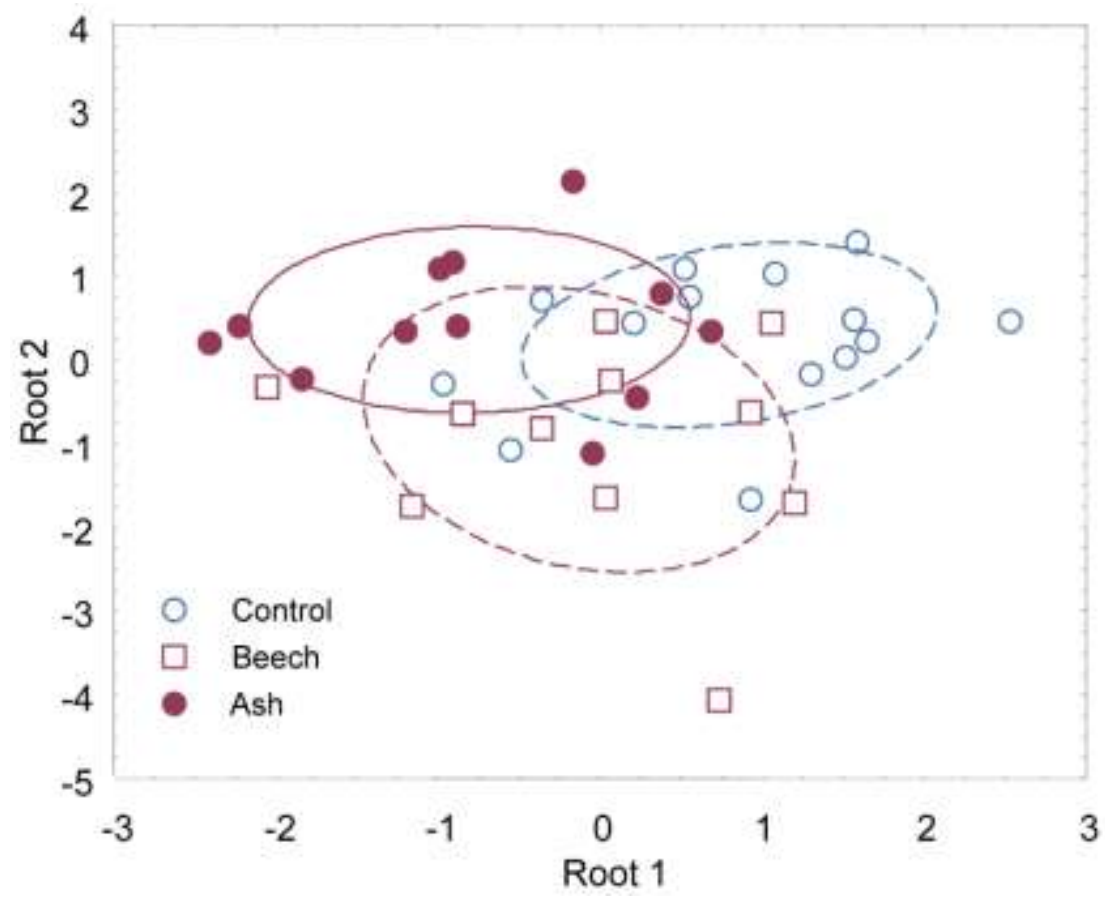

Fig 3 | Discriminat function analysis (DFA) of bacterial phyla based on pyrosequencing of $16 \mathrm{~S}$ rRNA in rhizotrons without trees (control) and with beech and ash saplings after reducing data to 6 dimensions by multidimensional scaling (MDS). Wilks' Lambda: 0.499576; $F(12,60)=2.07$; $P=0.0325$. Ellipses represent confidence intervals at $P=0.05$. 


\subsection{Microorganisms}

$\mathrm{C}_{\text {mic }}$ was not significantly affected by tree species and averaged over all treatments $141.25 \pm$ $4.93 \mu \mathrm{g} \mathrm{C} \mathrm{g} \mathrm{g}^{-1}$. However, $q \mathrm{O}_{2}$ was significantly higher in $\mathrm{B}+\left(0.0101 \pm 0.003 \mu \mathrm{l} \mathrm{O}_{2} \mathrm{mg}^{-1} \mathrm{C}_{\text {mic }}\right.$ $\mathrm{h}^{-1}$ ) than B- rhizotrons (-16\%, Table 5), which was due to marginally higher BAS in B+ (1.39 $\left.\pm 0.08 \mu \mathrm{l} \mathrm{O}_{2} \mathrm{~h}^{-1} \mathrm{~g}^{-1}\right)$ compared to B- rhizotrons (-15\%).

The ratio of fungal-to-bacterial marker PLFAs was significantly higher in $\mathrm{B}+(0.061 \pm 0.007)$ than in B- rhizotrons $(-53 \%)$ as the fungal biomass was higher in $\mathrm{B}+\left(0.43 \pm 0.08 \mathrm{nmol} \mathrm{g} \mathrm{g}^{-1} \mathrm{dry}\right.$ weight) than in B-rhizotrons (-47\%), whereas bacterial biomass remained unaffected.

Table 6 | Summary of input variables of the discriminant function analysis (DFA) of the composition of PLFA of the microbial community, soil properties and microbial respiration.

\begin{tabular}{|c|c|c|c|c|}
\hline & & Wilks' Lambda & $F(3,11)$ & $P$-level \\
\hline \multirow[t]{4}{*}{ Gram $^{+}$bacteria } & i15:0 & 0.0175 & 0.2171 & 0.8825 \\
\hline & a15:0 & 0.0242 & 1.7284 & 0.2188 \\
\hline & i16:0 & 0.0237 & 1.6062 & 0.2441 \\
\hline & i17:0 & 0.0430 & 5.8991 & 0.0119 \\
\hline \multirow[t]{2}{*}{ Gram$^{-}$bacteria } & cy17:0 & 0.0390 & 5.0135 & 0.0198 \\
\hline & cy19:0 & 0.0239 & 1.6448 & 0.2358 \\
\hline \multicolumn{5}{|l|}{ Unspecified } \\
\hline bacteria & $16: 1 \omega 7$ & 0.0250 & 1.8939 & 0.1891 \\
\hline Fungi & $18: 2 \omega 6: 9 c$ & 0.0298 & 2.9597 & 0.0792 \\
\hline \multicolumn{5}{|l|}{ Microbial } \\
\hline \multirow[t]{3}{*}{ respiration } & BAS & 0.0178 & 0.2972 & 0.8267 \\
\hline & $\mathrm{C}_{\text {mic }}$ & 0.0179 & 0.3145 & 0.8146 \\
\hline & $q \mathrm{O}_{2}$ & 0.0175 & 0.2325 & 0.8719 \\
\hline \multirow[t]{7}{*}{ Soil properties } & $\mathrm{pH}$ & 0.0320 & 3.4554 & 0.0549 \\
\hline & $\mathrm{NO}_{3}^{-}$ & 0.0211 & 1.0298 & 0.4170 \\
\hline & $\mathrm{NH}_{4}^{+}$ & 0.0188 & 0.5116 & 0.6825 \\
\hline & $\mathrm{C}_{\text {org }}$ & 0.0182 & 0.3726 & 0.7745 \\
\hline & $\mathrm{N}_{\text {total }}$ & 0.0261 & 2.1450 & 0.1524 \\
\hline & $\delta^{13} \mathrm{C}$ & 0.0221 & 1.2510 & 0.3384 \\
\hline & $\delta^{15} \mathrm{~N}$ & 0.0173 & 0.1733 & 0.9122 \\
\hline
\end{tabular}


Bacterial and total PLFA content were not significantly affected by the treatments and averaged $6.67 \pm 1.67$ and $7.00 \pm 0.53 \mathrm{nmol} \mathrm{g}{ }^{-1}$ dry weight, respectively. The $\delta^{13} \mathrm{C}$ values of the

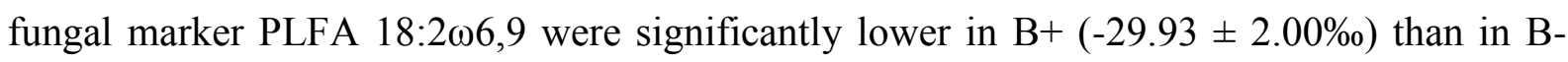
rhizotrons $\left(-18.75 \pm 3.60 \%\right.$ o). Also, weighted $\delta^{13} \mathrm{C}$ values of bacterial PLFAs were lower in $\mathrm{B}+(-26.28 \pm 0.97 \%)$ than in B- rhizotrons $(-24.40 \pm 0.84 \%)$, whereas in $\mathrm{A}+$ rhizotrons ($24.87 \pm 1.01 \%$ o $)$ they tended to be higher than in A- rhizotrons $(-25.82 \pm 0.89 \%$ ). In general, ash did not significantly influence $\delta^{13} \mathrm{C}$ values of marker PLFA (Table 5).

DFA suggests strong similarity in the composition of PLFAs in BB and BA rhizotrons. Both treatments differed strongly from the AA and the control treatment (Fig. 2). Differences were due to low amounts of gram-negative (i17:0) and gram-positive bacteria (cy17:0), higher fungal biomass and low $\mathrm{pH}$ (Table 6,7). Pyrosequencing of the bacterial community revealed high overlap of bacterial phyla and species with little differences between the treatments (Fig. 3).

Table 7 | Means \pm 1 SE of PLFA markers (nmol g ${ }^{-1}$ dry soil weight) of the microbial community.

\begin{tabular}{|c|c|c|c|c|c|}
\hline \multirow{2}{*}{\multicolumn{2}{|c|}{ PLFA marker }} & \multicolumn{2}{|c|}{ Beech absent (B-) } & \multicolumn{2}{|c|}{ Beech present $(\mathrm{B}+)$} \\
\hline & & $\begin{array}{c}\text { Ash absent } \\
\text { (A-) } \\
\text { (Control) } \\
\end{array}$ & $\begin{array}{c}\text { Ash present } \\
(\mathrm{A}+) \\
(\text { Ash })\end{array}$ & $\begin{array}{c}\text { Ash absent } \\
\text { (A-) } \\
\text { (Beech) }\end{array}$ & $\begin{array}{c}\text { Ash present } \\
(\mathbf{A}+) \\
\text { (Mixture) }\end{array}$ \\
\hline Gran & $\mathrm{i} 15: 0$ & $0.9 \pm 0.2$ & $0.81 \pm 0.36$ & $1.0 \pm 0.2$ & $1.59 \pm 0.35$ \\
\hline & a15:0 & $1.4 \pm 0.2$ & $1.04 \pm 0.34$ & $1.4 \pm 0.2$ & $1.93 \pm 0.24$ \\
\hline & i16:0 & $0.7 \pm 0.0$ & $0.66 \pm 0.12$ & $0.8 \pm 0.0$ & $0.87 \pm 0.06$ \\
\hline & $\mathrm{i} 17: 0$ & $0.6 \pm 0.0$ & $0.74 \pm 0.14$ & $0.4 \pm 0.0$ & $0.70 \pm 0.09$ \\
\hline \multirow[t]{2}{*}{ Gram $^{-}$bacteria } & cy $17: 0$ & $0.7 \pm 0.1$ & $0.77 \pm 0.13$ & $0.6 \pm 0.0$ & $0.84 \pm 0.16$ \\
\hline & cy19:0 & $1.2 \pm 0.5$ & $1.13 \pm 0.46$ & $1.1 \pm 0.2$ & $0.74 \pm 0.26$ \\
\hline Unspecinled & $16: 1 \omega 7$ & $1.3 \pm 0.3$ & $0.70 \pm 0.35$ & $0.8 \pm 0.2$ & $0.98 \pm 0.44$ \\
\hline Fungi & $18: 2 \omega 6$ & $0.2 \pm 0.1$ & $0.18 \pm 0.07$ & $0.3 \pm 0.0$ & $0.53 \pm 0.15$ \\
\hline
\end{tabular}

\subsection{Gamasid mites}

The ${ }^{13} \mathrm{C}$ and ${ }^{15} \mathrm{~N}$ from the added ash litter was incorporated into the soil food web as indicated by the label in the predatory mite $H$. aculeifer (Table 5). The signatures suggest that incorporation of label was most pronounced in mixed rhizotrons (significant interaction between beech and ash) followed by AA, BB and control rhizotrons. 


\section{Discussion}

\subsection{Changes in the microbial community due to rhizodeposition}

Lower $\mathrm{pH}$ in the rhizosphere of beech likely contributed to favoring soil fungi supporting our hypothesis (1) that beech and ash differentially affect the structure of the microbial community. Acidification of the soil by beech is well known (Holzwarth et al., 2011; Langenbruch et al., 2012), however, commonly it has been ascribed to low concentrations of calcium and magnesium and high concentrations of recalcitrant compounds such as lignin in beech leaf litter (Reich et al., 2005; Hobbie et al., 2006; Hansen et al., 2009). As we excluded leaf litter fall from saplings to the rhizotrons soil surface and uniformly placed high quality ash litter in each of the treatments, the observed differences must have been due to the activity of beech roots. Indeed, in the vicinity of beech roots concentrations of formate and acetate were increased as compared to control rhizotrons in the same experiment, whereas in the vicinity of ash roots only the concentration of acetate increased (Fender et al., 2012). The release of organic acids increases nutrient availability by functioning as reducing agent which is facilitated by low pH (Jones et al., 2004), probably a strategy of beech to make nutrients sequestered in its recalcitrant litter better available. Low $\mathrm{pH}$ in the soil, however, predominantly is caused by the release of $\mathrm{H}^{+}$by roots rather than by dissociation of organic acids (Neumann and Römheld, 1999). Accordingly, $\mathrm{H}^{+}$concentration was significantly higher in rhizotrons with beech, i.e. the $\mathrm{pH}$ was lower. Notably, acidification of the soil by beech roots occurred despite a comparatively lower root biomass in beech than ash rhizotrons. However, SRA and SRL were higher in B+ rhizotrons as compared to A+ rhizotrons. This suggests that the observed modifications were partly due to changes in root physiology rather than root biomass and number of fine root tips (Lehmann, 2003). Differences in the release rates of specific exudates of the two species presumably also contributed to the observed changes.

Bacterial community composition was little affected by tree roots as indicated by analysis of 16S rRNA. However, the ratio of fungal-to-bacterial biomass measured with PLFA analysis increased in $\mathrm{B}+$ rhizotrons and reflected the general pattern of increasing fungal dominance at low $\mathrm{pH}$ accounting for differences in soil processes (Aciego Pietri and Brookes, 2008; Rousk et al., 2009). Fungal biomass was measured using 18:206,9 as marker PLFA (Ruess and Chamberlain, 2010; Frostegård et al., 2011) which includes EM and saprotrophic fungi (Kaiser et al., 2010). We suggest the change in fungal biomass only to refer to EM and 


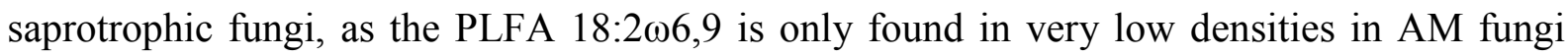
(Olsson and Johansen, 2000) and since the AM colonization rate did not change. Colonization by EM fungi in beech was relatively low ( $46 \pm 6 \%$, pooled data from BB and BA rhizotrons). This corresponds to low colonization rates in other greenhouse and rhizotron experiments (Dučić et al., 2009; Reich et al., 2009; Winkler et al., 2010) when compared to field data (Leuschner et al., 2004; Lang et al., 2011) suggesting that saprotrophic rather than EM fungi increased in beech rhizotrons. Further, lower $\delta^{13} \mathrm{C}$ values of PLFA 18:2 $\omega 6,9$ as compared to fine roots indicate that saprotrophic fungi substantially contributed to changes in the fungal marker PLFA.

Combined data on PLFAs, soil properties and microbial respiration in DFA revealed high similarity of beech and mixed rhizotrons with these differing significantly from ash and control rhizotrons. The fatty acids i17:0 and cy17:0 contributed most to this separation, with slighter contributions by $\mathrm{pH}$ and fungal biomass. The fatty acid i17:0 is regarded as marker for gram-positive bacteria whereas cy17:0 characterizes gram-negative bacteria, the former considered to dominate in microorganisms being present in bulk soil whereas the latter in rhizosphere soil processing labile root derived carbon (Söderberg et al., 2004; Paterson et al., 2007). The relative abundance of both was lowest in BB rhizotrons suggesting that both suffered from the presence of beech roots, presumably due to beech increasing the competitive strength of saprotrophic fungi.

\subsection{Changes in decomposition due to different tree species}

Hypothesis (2) assuming that litter decomposition is differentially affected by tree species was supported by our data. Generally, stable isotope values of the litter-soil mixture in MS decreased strongly during incubation by $-88 \%$ and $-81 \%$ for ${ }^{13} \mathrm{C}$ and ${ }^{15} \mathrm{~N}$, respectively. Ash litter is known to decompose fast; in the field it disappears entirely after two years (Jacob et al., 2009). High and constant temperatures within the climate chambers $\left(20^{\circ} \mathrm{C}\right)$ contributed to fast decomposition of the litter in the rhizotrons (Moore-Kucera and Dick, 2008). Data on higher $q \mathrm{O}_{2}$ (this study) and higher cumulative heterotrophic $\mathrm{CO}_{2}$ production in beech as compared to ash rhizotrons (Fender et al., 2012) suggest an overall higher stimulation of litter decomposition in beech root affected soil, i.e., higher carbon loss due to microbial respiration. High $\mathrm{H}^{+}$concentrations were shown to limit bacterial growth, while low concentrations limit fungal growth (Rousk et al., 2009). Since bacterial biomass did not decrease we suggest that bacteria were not repressed but their metabolic costs increased reflected in a higher $q \mathrm{O}_{2}$. By 
lowering $\mathrm{pH}$ beech decreased the efficiency of bacteria to use carbon for biomass production due to increased respiratory losses leading to higher carbon loss from soil. $\delta^{13} \mathrm{C}$ values in fungal and bacterial PLFAs were depleted most in B+rhizotrons suggesting that bacteria and fungi incorporated less litter carbon in presence of beech roots than of ash also indicating a faster turnover of litter carbon. Further, the more depleted $\delta^{13} \mathrm{C}$ values in fungi compared to fine roots suggest that fungal carbon originated from soil organic matter, whereas higher $\delta^{13} \mathrm{C}$ values in bacteria rather suggest bacteria to depend on root-derived carbon as their signatures resembled that of beech fine roots (Bowling et al., 2008).

Several studies found plant species identity to have stronger effects than plant diversity (De Deyn et al., 2004; Hättenschwiler and Gasser, 2005; Ball et al., 2009), as distinct plant species act as key species (Jacob et al., 2009). The strong effect of beech in this study is mediated by roots whereas ash had no effect suggesting that rhizodeposition in ash is of minor importance. Despite this low rhizosphere changes ash incorporated more litter nitrogen than beech (Lang and Polle, 2011; Schulz et al., 2011); potentially, ash is more effective in exploiting resources from fast decomposing litter such as ash leaves or by virtue of the higher root biomass production of ash in our experiment. Notably, ash saplings incorporated more litter ${ }^{15} \mathrm{~N}$ than beech saplings supporting the conclusion that the reduced $\mathrm{N}_{\text {total }}$ in $\mathrm{B}+$ rhizotrons was due to increased SOM decomposition and not due to plant uptake by beech. Notable the uptake of ${ }^{15} \mathrm{~N}$ declined in mixture with ash. This corresponds to field observations where the $\mathrm{N}$ concentrations in ash declined in mixtures with other tree species and their ectomycrrhizal diversity (Lang and Polle, 2011) A higher uptake of $\mathrm{N}$ by ash roots was also found in a ${ }^{15} \mathrm{~N}$ tracer study in the Hainich forest where ash fine roots showed a significantly higher massspecific uptake of labeled $\mathrm{NH}_{4}{ }^{+}$and glycine (but not of $\mathrm{NO}_{3}{ }^{-}$) than beech roots (A. Jacob, unpubl.).

\subsection{Channeling of litter-derived carbon into higher trophic levels}

Hypothesis (3) assuming that mixing of both tree species beneficially affects the microorganisms thereby stimulating carbon turnover is supported in part by our data. Generally, mixing of tree species increased plant biomass, fine root tips, SRA, SRL and mycorrhizal colonization especially that of beech saplings but did not affect soil chemistry and microorganisms. However, soil chemistry and microbial data are point measures and do not reflect fluxes over the whole period of the experiment. As the plants are sinks for 
resources made available over the whole experimental time higher plant growth in mixed rhizotrons suggests that the gross flux of resources was greater in these rhizotrons.

Isotope analyses of food web components are a net measure over the long experimental period. Here, we measured $\delta^{13} \mathrm{C}$ and $\delta^{15} \mathrm{~N}$ being incorporated within the predatory mite $H$. aculeifer. $\delta^{13} \mathrm{C}$ and $\delta^{15} \mathrm{~N}$ values of $H$. aculeifer were significantly increased in mixed rhizotrons suggesting that more litter-derived carbon and nitrogen entered the soil food web. In contrast, in control and beech rhizotrons $\delta^{13} \mathrm{C}$ values of $H$. aculeifer resembled those in the field $\left(\delta^{13} \mathrm{C}:-23.9 \pm 0.76 \% ; \delta^{15} \mathrm{~N}:+2.0 \pm 2.11 \%\right.$; Klarner et al., 2012) suggesting low incorporation of litter-derived carbon (and nitrogen) into the animal food web. However, the turnover of belowground $\mathrm{C}$ in unplanted soil, i.e., the control, was numerously shown to be lower compared to planted soil (Kuzyakov, 2010; Bird et al., 2011), i.e. soil with beech trees. Low incorporation of litter resources in BB rhizotrons may point to the fast decomposition of ash litter and to the dominance of root derived resources as basis of the soil animal food web in beech forests as suggested earlier (Pollierer et al., 2007).

\section{Conclusions}

The results suggest that the effect of living roots on litter decomposition, SOM dynamics and energy channels varies with tree species identity. Rhizodeposits have the potential to change soil $\mathrm{pH}$ with the potential to affect the metabolic activity of microorganisms. This propagates to higher trophic levels as tree species can impact the amount of litter-derived resource entering the soil food web and on energy channels. Effects of living roots are notoriously understudied and have to be included into studies on soil $\mathrm{C}$ dynamics to understand carbon and nutrient cycling as well as soil food web functioning of forests.

\section{Acknowledgements}

We thank Dr. Lars Köhler and Dr. Heinz Coners for technical support and Martin Blumberg for GC-MS measurements. This study was funded by the Ministry of Science and Culture of Lower Saxony and the 'Niedersächsisches Vorab' as part of the Cluster of Excellence 'Functional Biodiversity Research'. 


\section{References}

Aciego Pietri, J.C., Brookes, P.C., 2008. Relationships between soil pH and microbial properties in a UK arable soil. Soil Biology and Biochemistry 40, 1856-1861.

Agerer, R., 2001. Exploration types of ectomycorrhizae: A proposal to classify ectomycorrhizal mycelial systems according to their patterns of differentiation and putative ecological importance. Mycorrhiza 11, 107-114.

Anderson, J.P.E., Domsch, K.H., 1978. A physiological method for the quantitative measurement of microbial biomass in soils. Soil Biology and Biochemistry 10, 215-221.

Ball, B.A., Bradford, M.A., Coleman, D.C., Hunter, M.D., 2009. Linkages between below and aboveground communities: Decomposer responses to simulated tree species loss are largely additive. Soil Biology and Biochemistry 41, 1155-1163.

Beck, T., Joergensen, R.G., Kandeler, E., Makeschin, E., Nuss, E., Oberholzer, H.R., Scheu, S., 1997. An inter-laboratory comparison of ten different ways of measuring soil microbial biomass C. Soil Biology and Biochemistry 29, 1023-1032.

Bird, J.A., Herman, D.J., Firestone, M.K., 2011. Rhizosphere priming of soil organic matter by bacterial groups in a grassland soil. Soil Biology and Biochemistry 43, 718-725.

Bligh, E.G., Dyer, W.J., 1959. A rapid method of total lipid extraction and purification. Journal of Biochemistry and Physiology 37, 911-917.

Bowling, D.R., Pataki, D.E., Randerson, J.T., 2008. Carbon isotopes in terrestrial ecosystem pools and $\mathrm{CO}_{2}$ fluxes. New Phytologist 178, 24-40.

Broadmeadow M., Duncan, R., 2005. Climate Change and British Woodland. Forestry Commission Information Note 69.

Butler, J.L., Bottomley, P.J., Griffith, S.M., Myrold, D.D., 2004. Distribution and turnover of recently fixed photosynthate in ryegrass rhizospheres. Soil Biology and Biochemistry 36, 371-382. 
Butler, J.L., Williams, M.A., Bottomley, P.J., Myrold, D.D., Butler, J.L., Williams, M.A., Bottomley, P.J., Myrold, D.D., 2003. Microbial community dynamics associated with rhizosphere carbon flow. Applied and Environmental Microbiology 69, 6793-6800.

De Deyn, G.B., Raaijmakers, C.E., Ruijven, J.V., Berendse, F., Putten, W.H.V.D., 2004. Plant species identity and diversity effects on different trophic levels of nematodes in the soil food web. Oikos 106, 576-586.

Dučić, T., Berthold, D., Langenfeld-Heyser, R., Beese, F., Polle, A., 2009. Mycorrhizal communities in relation to biomass production and nutrient use efficiency in two varieties of Douglas fir (Pseudotsuga menziesii var. menziesii and var. glauca) in different forest soils. Soil Biology and Biochemistry 41, 742-753.

Edgar, R.C., 2010. Search and clustering orders of magnitude faster than BLAST. Bioinformatics 26, 2460-2461.

Emborg, J., 1998. Understorey light conditions and regeneration with respect to the structural dynamics of a near-natural temperate deciduous forest in Denmark. Forest Ecology and Management 106, 83-95.

Fender, A.-C, Gansert, D., Jungkunst, H.F., Fiedler, S., Beyer, F., Schützenmeister, K., Thiele B., Valtanen, K., Polle, A., Leschner, C., (2012). Root-induced tree species effects on the source/sink strength for greenhouse gases $\left(\mathrm{CH}_{4}, \mathrm{~N}_{2} \mathrm{O}\right.$ and $\left.\mathrm{CO}_{2}\right)$ of a temperate deciduous forest soil, Soil Biology \& Biochemistry.

Frostegård, A., Tunlid, A., Bååth, E., 1991. Microbial biomass measured as total lipid phosphate in soils of different organic content. Journal of Microbiological Methods 4, $151-163$.

Frostegård, Å., Tunlid, A., Bååth, E., 2011. Use and misuse of PLFA measurements in soils. Soil Biology and Biochemistry 43, 1621-1625.

Gartner, T.B., Cardon, Z.G., 2004. Decomposition dynamics in mixed-species leaf litter. Oikos 104, 230-246. 
Gessner, M.O., Swan, C.M., Dang, C.K., McKie, B.G., Bardgett, R.D., Wall, D.H., Hättenschwiler, S., 2010. Diversity meets decomposition. Trends in Ecology \& Evolution 25, 372-380.

Grayston, S.J., Wang, S., Campbell, C.D., Edwards, A.C., 1998. Selective influence of plant species on microbial diversity in the rhizosphere. Science 30, 369-378.

Gregory, P.J., 2006. Roots, rhizosphere and soil: the route to a better understanding of soil science? European Journal of Soil Science 57, 2-12.

Grime, J.P., Thompson, K., Hunt, R., Hodgson, J.G., Cornelissen, J.H.C., Rorison, I.H., Hendry, G.A.F., Ashenden, T.W., Askew, A.P., Band, S.R., Booth, R.E., Bossard, C.C., Campbell, B.D., Cooper, J.E.L., Davison, A.W., Gupta, P.L., Hall, W., Hand, D.W., Hannah, M.A., Hillier, S.H., Hodkinson, D.J., Jalili, A., Liu, Z., Mackey, J.M.L., Matthews, N., Mowforth, M.A., Neal, A.M., Reader, R.J., Reiling, K., Ross-Fraser, W., Spencer, R.E., Sutton, F., Tasker, D.E., Thorpe, P.C., Whitehouse, J., 1997. Integrated screening validates primary axes of specialisation in plants. Oikos 79, 259-281.

Hansen, K., Vesterdal, L., Schmidt, I.K., Gundersen, P., Sevel, L., Bastrup-Birk, A., Pedersen, L.B., Bille-Hansen, J., 2009. Litterfall and nutrient return in five tree species in a common garden experiment. Forest Ecology and Management 257, 2133-2144.

Hobbie, S.E., Reich, P.B., Oleksyn, J., Ogdahl, M., Zytkowiak, R., Hale, C., Karolewski, P., 2006. Tree species effects on decomposition and forest floor dynamics in a common garden. Ecology 87, 2288-2297.

Holzwarth, F.M., M, D., Flessa, H., 2011. Effects of beech and ash on small-scale variation of soil acidity and nutrient stocks in a mixed deciduous forest. Journal of Plant Nutrition and Soil Science 174, 799-808.

Hättenschwiler, S., Gasser, P., 2005. Soil animals alter plant litter diversity effects on decomposition. Proceedings of the National Academy of Sciences of the United States of America 102, 1519-1524. 
Hättenschwiler, S., Tiunov, A.V., Scheu, S., 2005. Biodiversity and Litter Decomposition in Terrestrial Ecosystems. Annual Review of Ecology, Evolution, and Systematics 36, 191218.

Jacob, M., Viedenz, K., Polle, A., Thomas, F.M., 2010. Leaf litter decomposition in temperate deciduous forest stands with a decreasing fraction of beech (Fagus sylvatica). Oecologia 164, 1083-1094.

Jacob, M., Weland, N., Platner, C., Schaefer, M., Leuschner, C., Thomas, F.M., 2009. Nutrient release from decomposing leaf litter of temperate deciduous forest trees along a gradient of increasing tree species diversity. Soil Biology and Biochemistry 41, 21222130.

Jones, D.L., Hodge, A., Kuzyakov, Y., 2004. Plant and mycorrhizal regulation of rhizodeposition. New Phytologist 163, 459-480.

Kaiser, C., Frank, A., Wild, B., Koranda, M., Richter, A., 2010. Negligible contribution from roots to soil-borne phospholipid fatty acid fungal biomarkers 18: 2w6,9 and 18:1w9. Soil Biology and Biochemistry 42, 1650-1652.

Kempson, D., Lloyd, M., Ghelardi, R., 1963. A new extractor for woodland litter. Pedobiologia 3, 1-21.

Klarner et al 2012 accepted

Kuzyakov, Y., 2010. Priming effects: Interactions between living and dead organic matter. Soil Biology and Biochemistry 42, 1363-1371.

Lang, C., Seven, J., Polle, A., 2011. Host preferences and differential contributions of deciduous tree species shape mycorrhizal species richness in a mixed Central European forest. Mycorrhiza 21, 297-308.

Lang, C. \& Polle, A. (2011), 'Ectomycorrhizal fungal diversity, tree diversity and root nutrient relations in a mixed central european forest.', Tree Physiology 31(5), 531538. 
Langenbruch, C., Helfrich, M., Flessa, H., 2012. Effects of beech (Fagus sylvatica), ash (Fraxinus excelsior) and lime (Tilia spec.) on soil chemical properties in a mixed deciduous forest. Plant and Soil 352, 389-403.

Lehmann, J., 2003. Subsoil root activity in tree-based cropping systems. Plant and Soil 255, 319-331.

Leuschner, C., Hertel, D., Schmid, I., Koch, O., Muhs, A.\&, Hölscher, D., 2004. Stand fine root biomass and fine root morphology in old-growth beech forests as a function of precipitation and soil fertility. Plant and Soil 258, 43-56.

McGonigle, T.P., Millers, M.H., Evans, D.G., Fairchild, G.L., Swan, J.A., 1990. A new method which gives an objective measure of colonization of roots by vesiculararbuscular mycorrhizal fungi. New Phytologist 115, 495-501.

McKinley, D.C., Ryan, M.G., Birdsey, R.A., Giardina, C.P., Harmon, M.E., Heath, L.S., Houghton, R.A., Jackson, R.B., Morrison, J.F., Murray, B.C., Pataki, D.E., Skog, K.E., 2011. A synthesis of current knowledge on forests and carbon storage in the United States. Ecological Applications 21, 1902-1924.

Meinen, C., Hertel, D., Leuschner, C., 2009. Biomass and morphology of fine roots in temperate broad-leaved forests differing in tree species diversity: is there evidence of below-ground overyielding? Oecologia 161, 99-111.

Moore-Kucera, J., Dick, R.P., 2008. Application of 13C-labeled litter and root materials for in situ decomposition studies using phospholipid fatty acids. Soil Biology and Biochemistry 40, 2485-2493.

Nacke, H., Thürmer, A., Wollherr, A., Will, C., Hodac, L., Herold, N., Schöning, I., Schrumpf, M., Daniel, R., 2011. Pyrosequencing-based assessment of bacterial community structure along different management types in German forest and grassland soils. PloS one 6, e17000.

Neumann, G., Römheld, V., 1999. Root excretion of carboxylic acids and protons in phosphorus-deficient plants. Plant and Soil 211, 121-130. 
Olsson, P.A., Johansen, A., 2000. Lipid and fatty acid composition of hyphae and spores of arbuscular mycorrhizal fungi at different growth stages. Mycological Research 104, 429434.

Olsson, P.A., Johnson, N.A., 2005. Tracking carbon from the atmosphere to the rhizosphere. Ecology Letters 8, 1264-1270.

Paterson, E., Gebbing, T., Abel, C., Sim, A., Telfer, G., 2007. Rhizodeposition shapes rhizosphere microbial community structure in organic soil. New Phytologist 173, 600610.

Paterson, E., Midwood, A.J., Millard, P., 2009. Through the eye of the needle: a review of isotope approaches to quantify microbial processes mediating soil carbon balance. New Phytologist 184, 19-33.

Pollierer, M.M., Langel, R., Körner, C., Maraun, M., Scheu, S., 2007. The underestimated importance of belowground carbon input for forest soil animal food webs. Ecology Letters 10, 729-736.

Reeder, J., Knight, R., 2010. Rapidly denoising pyrosequencing amplicon reads by exploiting rank abundance distributions. Nature Methods 7, 668-669.

Reich, M., Göbel, C., Kohler, A., Buée, M., Martin, F., Feussner, I., Polle, A., 2009. Fatty acid metabolism in the ectomycorrhizal fungus Laccaria bicolor. New Phytologist 182, 950-964.

Reich, P.B., Oleksyn, J., Modrzynski, J., Mrozinski, P., Hobbie, S.E., Eissenstat, D.M., Chorover, J., Chadwick, O.A., Hale, C.M., Tjoelker, M.G., 2005. Linking litter calcium, earthworms and soil properties: a common garden test with 14 tree species. Ecology Letters 8, 811-818.

Rousk, J., Brookes, P.C., Bååth, E., 2009. Contrasting soil pH effects on fungal and bacterial growth suggest functional redundancy in carbon mineralization. Applied and Environmental Microbiology 75, 1589-1596. 
Ruess, L., Chamberlain, P.M., 2010. The fat that matters: Soil food web analysis using fatty acids and their carbon stable isotope signature. Soil Biology and Biochemistry 42, 18981910.

Scheu, S., 1992. Automated measurement of the respiratory response of soil microcompartments: active microbial biomass in earthworm faces. Soil Biology and Biochemistry 24, 1113-1118.

Schlesinger, W.H., Andrews, J.A., 2000. Soil respiration and the global carbon cycle. Biogeochemistry 48, 7-20.

Schloss, P.D., Handelsman, J., 2005. Introducing DOTUR, a computer program for defining operational taxonomic units and estimating species richness. Applied and Environmental Microbiology 71, 1501-1506.

Schmalenberger, A., Schwieger, F., Tebbe, C., 2001. Effect of primers hybridizing to different evolutionarily conserved regions of the small-subunit rRNA Gene in PCRbased microbial community analyses and genetic profiling. Applied and Environmental Microbiology 67, 3557-3563.

Schulz, H., Härtling, S., Stange, C.F., 2011. Species-specific differences in nitrogen uptake and utilization by six European tree species. Journal of Plant Nutrition and Soil Science $174,28-37$.

Schmitz, O., Danneberg, G., Hundeshagen, B., Klinger, A., H, B., 1991. Quantification of vesicular-arbuscular mycorrhiza by biochemical parameters. Journal of Plant Physiology $139,104-114$.

Smith, S., Read, D.J., 2008. Mycorrhizal symbiosis. Cambridge, UK, Academic Press.

Steinbeiss, S., Beßler, H., Engels, C., Temperton, V.M., Buchmann, N., Roscher, C., Kreutziger, Y., Baade, J., Habekost, M., Gleixner, G., 2008. Plant diversity positively affects short-term soil carbon storage in experimental grasslands. Global Change Biology 14, 2937-2949. 
Swift, M.J., Heal, O.W., Anderson, J.M., 1979. Decomposition in terrestrial ecosystems. University of California Press, Berkeley.

Söderberg, K.H., Probanza, a., Jumpponen, a., Bååth, E., 2004. The microbial community in the rhizosphere determined by community-level physiological profiles (CLPP) and direct soil- and cfu-PLFA techniques. Applied Soil Ecology 25, 135-145.

Wardle, D.A., 1998. Review controls of temporal variability of the soil microbial biomass: a global-scale synthesis. Soil Biology \& Biochemistry 30, 1867-1878.

Weber-Blaschke, G., Claus, M., Rehfuss, K.E., 2002. Growth and nutrition of ash (Fraxinus excelsior L.) and sycamore (Acer pseudoplatanus L.) on soils of different base saturation in pot experiments. Forest Ecology and Management 167, 43-56.

Winkler, J.B., Dannenmann, M., Simon, J., Pena, R., Offermann, C., Sternad, W., Clemenz, C., Naumann, P.S., Gasche, R., Kögel-Knabner, I., Gessler, A., Rennenberg, H., Polle, A. 2010. Carbon and nitrogen balance in beech roots under competitive pressure of soilborne microorganisms induced by girdling, drought and glucose application. Functional Plant Biology 37, 879-889. 


\section{Figure legends}

Fig. 1 Scheme of double split-root rhizotrons. (a) Front view of mixed species treatments with ash (left) and beech (right) roots interacting in the central compartment. Circles represent manipulation sites (MS) with soil (open circles) or soil-litter mixture (grey circles). The shaded area refers to the surrounding sampling site (SS). Roman numerals indicate soil depths (I-VI). The bold rim in the central compartment from soil depth II to VI represents the sampling area. Black dots along the central dashed line refer to the position of temperature sensors. Dashed lines mark the sampling grid. (b) Side view of the double split-root rhizotron and assembly of MS. Tubes inside MS can be withdrawn to fill them with litter and/or soil. A water flux based cooling system is installed at the back panel. A valve allowed drainage of the rhizotrons.

Fig. 2 Discriminant function analysis (DFA) of microbial PLFAs, microbial respiration and soil properties in rhizotrons without trees (control), with beech, ash and a mixture of beech and ash. Wilks' Lambda: 0.016480, F $(54,33)=1.85, P=0.0296$. Ellipses represent confidence intervals at $P=0.05$.

Fig. 3 Discriminat function analysis (DFA) of bacterial phyla based on pyrosequencing of 16S rRNA in rhizotrons without trees (control) and with beech and ash saplings after reducing data to six dimensions by multidimensional scaling (MDS). Wilks' Lambda: $0.499576 ; F_{(12,60)}$ $=2.07 ; P=0.0325$. Ellipses represent confidence intervals at $P=0.05$. 
Table 2 Soil characteristics (means $\pm 1 \mathrm{SE}$ ) at the start of the experiment.

\begin{tabular}{|c|c|c|c|}
\hline Soil parameter & & & \\
\hline $\mathrm{pH}$ & 4.56 & \pm & 0.03 \\
\hline $\mathrm{CEC}\left[\mu \mathrm{mol}_{\mathrm{c}} \mathrm{g}^{-1}\right.$ dry weight $]$ & 191.70 & \pm & 11.80 \\
\hline Base saturation [\%] & 22.90 & \pm & 1.30 \\
\hline $\mathrm{N}-\mathrm{NO}_{3}{ }^{-}\left[\mathrm{mg} \mathrm{kg}^{-1}\right.$ dry weight $]$ & 4.89 & \pm & 0.20 \\
\hline $\mathrm{N}-\mathrm{NH}_{4}{ }^{+}\left[\mathrm{mg} \mathrm{kg}^{-1}\right.$ dry weight $]$ & 6.00 & \pm & 0.22 \\
\hline $\mathrm{C}_{\text {org }}\left[\mathrm{g} \mathrm{kg}^{-1}\right.$ dry weight $]$ & 19.20 & \pm & 0.30 \\
\hline $\mathrm{N}_{\text {total }}\left[\mathrm{g} \mathrm{kg}^{-1}\right.$ dry weight] & 1.64 & \pm & 0.01 \\
\hline $\mathrm{C} / \mathrm{N}$ ratio $\left[\mathrm{g} \mathrm{g}^{-1}\right]$ & 11.70 & \pm & 0.14 \\
\hline $\mathrm{C}_{\text {mic }}\left[\mu \mathrm{g} \mathrm{C} \mathrm{g}^{-1}\right.$ dry weight $]$ & 382.80 & \pm & 14.60 \\
\hline
\end{tabular}

CEC: cation exchange capacity; $\mathrm{C}_{\text {mic }}$ : microbial carbon 
Table 2: Means \pm 1 SE and $T$ - and $P$-values of plant biomass of beech and ash saplings at the start of the experiment (in g plant ${ }^{-1} ; n=5$ ).

\begin{tabular}{|c|c|c|c|c|c|c|}
\hline \multirow{4}{*}{ Biomass } & \multicolumn{6}{|c|}{ Initial Biomass } \\
\hline & \multicolumn{2}{|c|}{ Beech } & \multicolumn{2}{|c|}{$\begin{array}{r}\text { Ash } \\
\text { Means }\end{array}$} & \multirow[b]{2}{*}{$T$} & \multirow[b]{2}{*}{$P$} \\
\hline & Means & SE & $\mathrm{SE}$ & & & \\
\hline & & & & & & \\
\hline Total & $2.04 \pm$ & 0.46 & $2.13 \pm$ & \pm 0.22 & 0.15 & 0.7122 \\
\hline $\begin{array}{l}\text { Total } \\
\text { aboveground } \\
\text { Total }\end{array}$ & $1.26 \pm$ & 0.27 & $1.25 \pm$ & \pm 0.15 & 0.01 & 0.9294 \\
\hline belowground & $0.78 \pm$ & 0.20 & $0.88 \pm$ & \pm 0.08 & 0.81 & 0.3933 \\
\hline Shoots & $0.88 \pm$ & 0.22 & $0.74 \pm$ & \pm 0.09 & 0.27 & 0.6190 \\
\hline Leaves & $0.38 \pm$ & 0.05 & $0.52 \pm$ & \pm 0.07 & 2.49 & 0.1530 \\
\hline Fine roots & $0.16 \pm$ & 0.05 & $0.41 \pm$ & +0.08 & 6.49 & 0.0343 \\
\hline Coarse roots & $0.64 \pm$ & 0.17 & $0.56 \pm$ & \pm 0.06 & 0.08 & 0.7866 \\
\hline
\end{tabular}


Table 3 Isotopic signatures of the used soil, labeled ash litter and of the soil-litter-mixture in manipulation sites at the start of the experiment and at the end after 422 days of litter incubation (means $\pm 1 \mathrm{SE})$.

\begin{tabular}{|c|c|c|c|c|c|}
\hline & \multicolumn{3}{|c|}{ Start } & \multirow{2}{*}{$\begin{array}{c}\text { End } \\
\begin{array}{c}\text { Soil-litter } \\
\text { mixture }\end{array}\end{array}$} & \multirow[b]{2}{*}{$\begin{array}{c}\text { Difference* }^{*} \\
{[\%]}\end{array}$} \\
\hline & Soil & Litter & $\begin{array}{l}\text { Soil-litter } \\
\text { mixture }\end{array}$ & & \\
\hline$\delta^{13} \mathrm{C}$ & - \pm 0.10 & $146.80 \pm 0.32$ & $69.00 \pm 0.60$ & $-17.44 \pm 1.86$ & 88.25 \\
\hline [\%o] & 26.20 & & & & \\
\hline $\begin{array}{l}\delta^{15} \mathbf{N} \\
{[\% o]}\end{array}$ & $1.60 \pm 0.16$ & $13139.30 \pm 59.10$ & $6153.80 \pm 0.40$ & $577.38 \pm 124.88$ & 81.23 \\
\hline $\begin{array}{l}\mathrm{C} \\
{[\%]}\end{array}$ & $1.92 \pm 0.03$ & $36.05 \pm 0.09$ & $5.93 \pm 0.05$ & $1.94 \pm 0.06$ & 65.34 \\
\hline $\begin{array}{l}\mathbf{N} \\
{[\%]}\end{array}$ & $0.16 \pm 0.00$ & $1.85 \pm 0.01$ & $0.40 \pm 0.00$ & $0.18 \pm 0.004$ & 54.82 \\
\hline $\mathbf{C} / \mathbf{N}$ & $11.70 \pm 0.10$ & $19.50 \pm 0.10$ & $14.90 \pm 0.10$ & $10.98 \pm 0.12$ & 15.33 \\
\hline
\end{tabular}

* Differences between the signatures from the start and the end of the experiment are displayed for soil samples from manipulation sites overall treatments $(n=16)$ and were related to natural isotopic signatures of ash litter (V. Eißfeller, unpubl. data). 
Table 4 Means \pm 1 SE for plant parameters per plant in rhizotrons planted with beech trees $(\mathrm{BB})$, ash trees $(\mathrm{AA})$, beech trees in mixture $(\mathrm{BA})$ and ash trees in mixture $(\mathrm{AB})$ as well as GLM table of contrasts after 475 days.

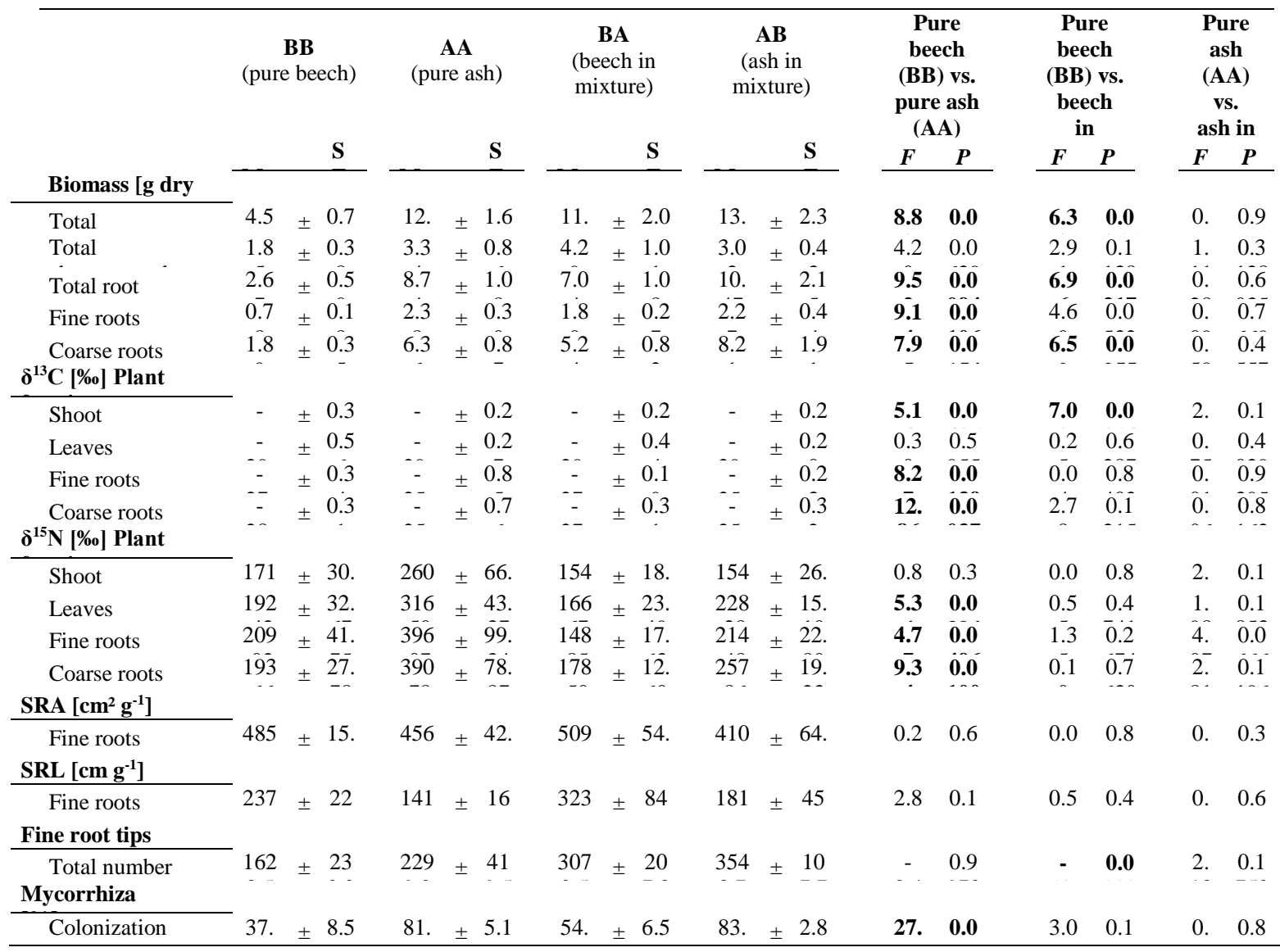

$\dagger$ Note that the different type of mycorrhiza in beech and ash demanded for special counting techniques, thus direct comparisons have to be treated with caution but allow comparison with trees in the mixture. 
Table 5 Means \pm 1 SE for soil and microbial parameters and on signatures in gamasid mited as influenced by beech (B) and ash (A) as well as the ANOVA table of $F$ - and $P$-values in rhizotrons after 475 days.

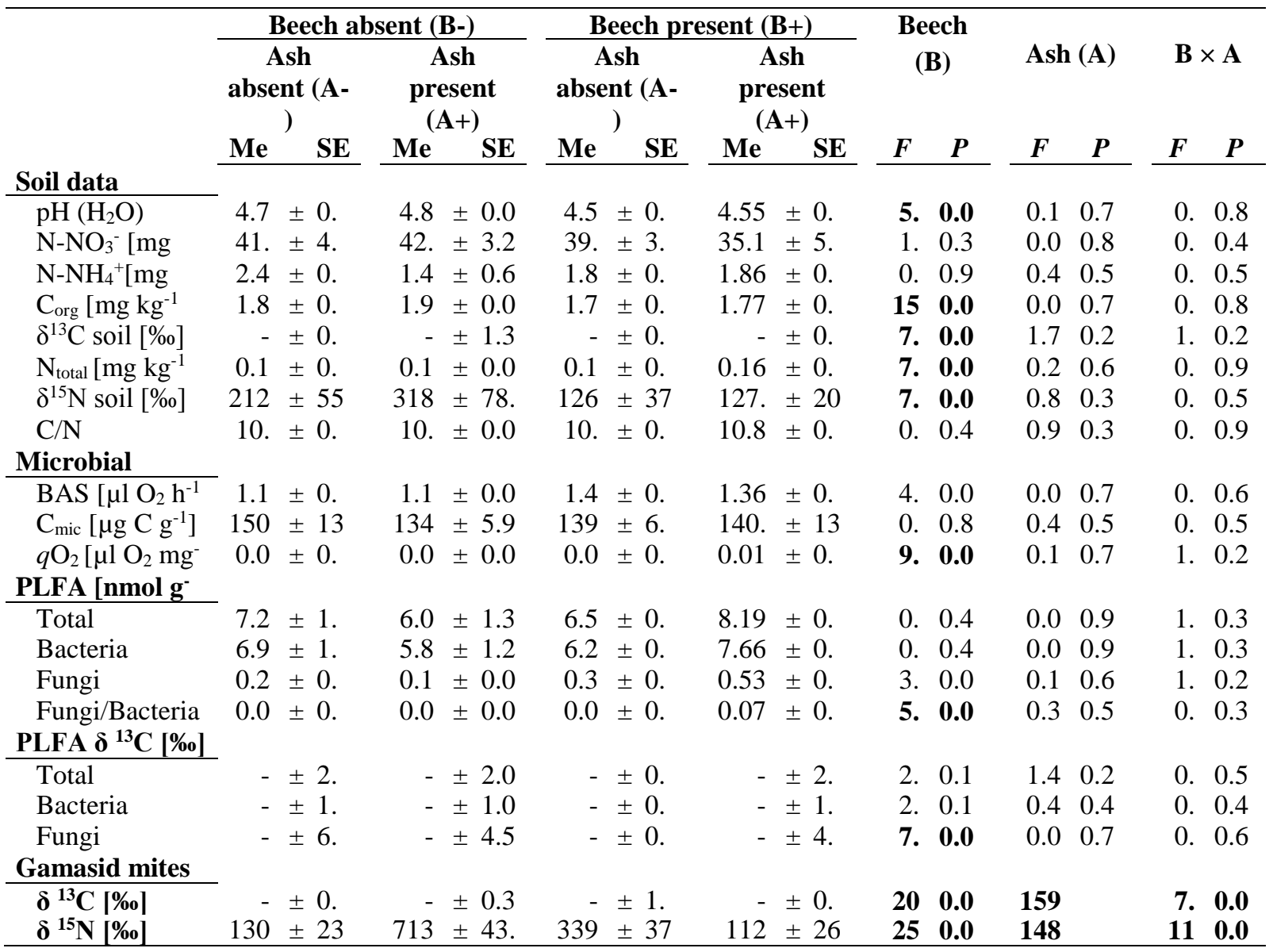


Table 6 Summary of input variables of the discriminant function analysis (DFA), i.e. data on PLFA, soil properties and microbial respiration.

\begin{tabular}{llccc}
\hline & & Wilks' Lambda & F (3,11) & P-level \\
\hline Gram $^{+}$bacteria & $\mathrm{i} 15: 0$ & 0.0175 & 0.2171 & 0.8825 \\
& $\mathrm{a} 15: 0$ & 0.0242 & 1.7284 & 0.2188 \\
& $\mathrm{i} 16: 0$ & 0.0237 & 1.6062 & 0.2441 \\
& $\mathbf{i 1 7 : 0}$ & $\mathbf{0 . 0 4 3 0}$ & $\mathbf{5 . 8 9 9 1}$ & $\mathbf{0 . 0 1 1 9}$ \\
Gram ${ }^{-}$bacteria & $\mathbf{c y 1 7 : 0}$ & $\mathbf{0 . 0 3 9 0}$ & $\mathbf{5 . 0 1 3 5}$ & $\mathbf{0 . 0 1 9 8}$ \\
& $\mathrm{cy} 19: 0$ & 0.0239 & 1.6448 & 0.2358 \\
Unspecified bacteria & $16: 1 \omega 7$ & 0.0250 & 1.8939 & 0.1891 \\
Fungi & $18: 2 \omega 6: 9 \mathrm{c}$ & 0.0298 & 2.9597 & 0.0792 \\
Microbial respiration & $\mathrm{BAS}$ & 0.0178 & 0.2972 & 0.8267 \\
& $\mathrm{C}_{\text {mic }}$ & 0.0179 & 0.3145 & 0.8146 \\
Soil properties & $q \mathrm{O}_{2}$ & 0.0175 & 0.2325 & 0.8719 \\
& $\mathrm{pH}^{-}$ & 0.0320 & 3.4554 & 0.0549 \\
& $\mathrm{NO}_{3}{ }^{-}$ & 0.0211 & 1.0298 & 0.4170 \\
& $\mathrm{NH}_{4}{ }^{+}$ & 0.0188 & 0.5116 & 0.6825 \\
& $\mathrm{C}_{\text {org }}$ & 0.0182 & 0.3726 & 0.7745 \\
& $\mathrm{~N}_{\text {total }}$ & 0.0261 & 2.1450 & 0.1524 \\
& $\delta^{13} \mathrm{C}$ & 0.0221 & 1.2510 & 0.3384 \\
& $\delta^{15} \mathrm{~N}$ & 0.0173 & 0.1733 & 0.9122 \\
\hline
\end{tabular}


Table 7 Means \pm 1 SE of PLFA markers of the microbial community in rhizotrons after 475 days.

\begin{tabular}{|c|c|c|c|c|c|}
\hline & & \multicolumn{2}{|c|}{ Beech absent (B+) } & \multicolumn{2}{|c|}{ Beech present (B-) } \\
\hline & & $\begin{array}{c}\text { Ash absent } \\
\text { (A-) }\end{array}$ & $\begin{array}{c}\text { Ash present } \\
(\mathrm{A}+)\end{array}$ & $\begin{array}{c}\text { Ash absent } \\
\text { (A-) }\end{array}$ & $\begin{array}{c}\text { Ash present } \\
(A+)\end{array}$ \\
\hline \multicolumn{2}{|l|}{ PLFA marker } & (Control) & (Ash) & (Beech) & (Mixture) \\
\hline \multirow[t]{4}{*}{$\mathrm{Gram}^{+}$bacteria } & $\mathrm{i} 15: 0$ & $0.92 \pm 0.22$ & $0.81 \pm 0.36$ & $1.05 \pm 0.21$ & $1.59 \pm 0.35$ \\
\hline & a15:0 & $1.41 \pm 0.29$ & $1.04 \pm 0.34$ & $1.40 \pm 0.24$ & $1.93 \pm 0.24$ \\
\hline & i16:0 & $0.70 \pm 0.08$ & $0.66 \pm 0.12$ & $0.80 \pm 0.06$ & $0.87 \pm 0.06$ \\
\hline & $\mathrm{i} 17: 0$ & $0.62 \pm 0.05$ & $0.74 \pm 0.14$ & $0.42 \pm 0.04$ & $0.70 \pm 0.09$ \\
\hline \multirow[t]{2}{*}{$\mathrm{Gram}^{-}$bacteria } & cy $17: 0$ & $0.72 \pm 0.16$ & $0.77 \pm 0.13$ & $0.63 \pm 0.06$ & $0.84 \pm 0.16$ \\
\hline & cy19:0 & $1.22 \pm 0.58$ & $1.13 \pm 0.46$ & $1.13 \pm 0.22$ & $0.74 \pm 0.26$ \\
\hline fied & $16: 1 \omega$ & $1.35 \pm 0.37$ & $0.70 \pm 0.35$ & $0.81 \pm 0.21$ & $0.98 \pm 0.44$ \\
\hline Fungi & $18: 2 \omega$ & $0.27 \pm 0.16$ & $0.18 \pm 0.07$ & $0.33 \pm 0.05$ & $0.53 \pm 0.15$ \\
\hline
\end{tabular}




\section{Appendix 2}

Beech carbon productivity as driver of ectomycorrhizal abundance and diversity (2009), Drübert, C., Lang, C., Valtanen, K. \& Polle, A. Plant, Cell and Environment 32, 922-1003. 


\title{
Beech carbon productivity as driver of ectomycorrhizal abundance and diversity
}

\author{
CHRISTINE DRUEBERT, CHRISTA LANG, KERTTU VALTANEN \& ANDREA POLLE \\ Büsgen-Institut, Abteilung Forstbotanik und Baumphysiologie, Georg-August Universität Göttingen, Büsgenweg 2, 37077
}

Göttingen, Germany

\begin{abstract}
We tested the hypothesis that carbon productivity of beech (Fagus sylvatica) controls ectomycorrhizal colonization, diversity and community structures. Carbon productivity was limited by long-term shading or by girdling. The trees were grown in compost soil to avoid nutrient deficiencies. Despite severe limitation in photosynthesis and biomass production by shading, the concentrations of carbohydrates in roots were unaffected by the light level. Shadeacclimated plants were only $10 \%$ and sun-acclimated plants were $74 \%$ colonized by ectomycorrhiza. EM diversity was higher on roots with high than at roots with low mycorrhizal colonization. Evenness was unaffected by any treatment. Low mycorrhizal colonization had no negative effects on plant mineral nutrition. In girdled plants mycorrhizal colonization and diversity were retained although ${ }^{14} \mathrm{C}$-leaf feeding showed almost complete disruption of carbon transport from leaves to roots. Carbohydrate storage pools in roots decreased upon girdling. Our results show that plant carbon productivity was the reason for and not the result of high ectomycorrhizal diversity. We suggest that ectomycorrhiza can be supplied by two carbon routes: recent photosynthate and stored carbohydrates. Storage pools may be important for ectomycorrhizal survival when photoassimilates were unavailable, probably feeding preferentially less carbon demanding EM species as shifts in community composition were found.
\end{abstract}

Key-words:beech;diversity;invisibility;nitrogen;productivity; understory ecology.

\section{INTRODUCTION}

Soil microbes are considered as important drivers of plant diversity and productivity in terrestrial ecosystems (van der Heijden, Bardgett \& van Straalen 2008). Mycorrhizal fungi play a pivotal role in this respect. In boreal and temperate forests, which are usually nitrogen limited, trees depend on their associated ectomycorrhizal mutualists to supply them with sufficient amounts of nutrients (Read \& Perez-Moreno 2003). About $75 \%$ of annual phosphorus uptake and up to

Correspondence: A. Polle. Fax: +49 551 3922705; e-mail: apolle@ gwdg.de

$80 \%$ of nitrogen are derived from mycorrhizal fungi (Simard, Jones \& Durall 2002; Hobbie \& Hobbie 2006; van der Heijden et al. 2008).

The colonization and diversity of ectomycorrhizal fungi at roots of forests trees is usually high (De Roman,Claveria \& De Miguel 2005).The factors controlling this diversity are barely understood but abiotic factors such as soil chemistry or anthropogenic impacts such as increasing nitrogen deposition are important components (Brandrud 1995; Markkola et al. 1995; Peter, Francois \& Egli 2001; Lilleskov et al. 2002). Although it is generally assumed that high diversity will stabilize ecosystem functions and services, the role of ectomycorrhizal communities in this respect is unknown (Johnson et al. 2005).Experimental evidence supporting functional roles of mycorrhizal diversity in maintaining plant productivity and diversity mainly stems from studies of arbuscular mycorrhizal fungi in grassland ecosystems, where high diversity of arbuscular mycorrhizal fungi enhanced plant productivity or altered the distribution of nutrients amongst co-existing grassland species (Grime et al. 1987; van der Heijden et al. 1998; van der Heijden et al. 2006; Vogelsang, Reynolds \& Bever 2006). However, plants are also expected to affect belowground microbial communities for example by carbon supply and root exudates, thus, providing feedback loops (Bais et al. 2006).

Surprisingly little is known on the question how plant productivity affects ectomycorrhizal fungal associations and their diversity and whether plants can control these communities (Johnson et al. 2005). Ectomycorrhizal fungal associations are thought to place a high carbon demand on the host plant and, thus, plant-fungal interactions may not always be positive, especially when carbon resources are limited. In microcosm studies, as much as 20 to $30 \%$ of current assimilate was allocated to ectomycorrhizal fungi (Finlay \& Söderström 1992; Söderström 2002). EM fungi provide the most important path of plantderived carbon into soil (Godbold et al. 2006), and recent estimates suggest figures of up to $22 \%$ of total plant carbon allocation to ectomycorrhiza (Hobbie 2006). Already early tracer studies indicate that photoassimilates are rapidly translocated to 
the roots of ectomycorrhizal plants (Melin \& Nilsson 1957). When the carbon transport pathway to the roots was interrupted by girdling, soil respiration decreased by $50 \%$ in a boreal Scots pine forest (Högberg et al. 2001).Separation of heterotrophic, root and hyphal respiration indicated that ectomycorrhizal hyphae contributed $25 \%$ to soil $\mathrm{CO}_{2}$ flux (Heinemeyer, Hartley \& Evans 2007). These examples underline the carbon costs incurred by ectomycorrhizas. If costs and benefits were directly linked,alterations in carbon supply are expected to directly affect root colonization and community structures. However, when carbon flow to ectomycorrhiza was restricted by defoliation of previous-year needles of Scots pine, no effects on below-ground diversity in term of the number of morphotypes or morphotype diversity index were observed, but the formation of sporocarps decreased (Kuikka et al. 2003). Other studies indicated that alterations in carbon availability either by defoliation or by enhancing supply through exposure to elevated $\mathrm{CO}_{2}$ affected fungal community structures (Godbold \& Berntson 1997; Saikkonen et al. 1999; Parrent, Morris \& Vigalys 2006).

In forest ecosystems light is frequently a growth limiting resource. Very little is known on whether light-driven increases in productivity affect the abundance,diversity and community structures of ectomycorrhizas. In experimental studies, colonization with arbuscular mycorrhizal fungi showed a positive relationship with light availability (Pearson, Smith \& Smith 1991; Vierheilig et al. 2002; Gamage, Singhakumara \& Ashton 2004; Gehring 2004). In contrast to this, a pot study with birch and conifers under controlled conditions showed no influence of light on ectomycorrhizal colonization (Dehlin et al. 2004). Field studies of birch grown in understory, gaps and clearings suggested that increasing light availability would increase ectomycorrhizal colonization of roots (Cheng, Widden $\&$ Messier 2005). However, clear correlations were not obtained because other factors such as soil properties and plant age also varied in this field study and the shade-tolerance of birch as an early succession species is limited.

In Central Europe, European beech (Fagus sylvatica L.) dominates the natural forest communities forming monospecific stands in a broad range of environmental conditions (Ellenberg 1996).In the juvenile phase, beech trees are very shade-tolerant, but can also adapt to high irradiation displaying considerable phenotypic and ecophysiological plasticity (Johnson et al. 1997; Parelle, Roudaut \& Ducrey 2006). European beech, like all Fagaceae, forms only ectomycorrhizal symbioses, which are considered as ecologically obligate for this tree species.

In the present study, we used European beech to address the question whether plant productivity affects ectomycorrhizal colonization and diversity. In our field experimental study, young beech trees were grown densely like natural regeneration forming closed canopies in a nutrient rich soil to avoid nitrogen limitations. Net primary productivity was manipulated by longterm shading to test whether differences in productivity would cause changes in the abundance of fungal partners, and in return affect nutrient allocation to plant tissues. To distinguish between recent and stored assimilate supply on abundance and diversity of ectomycorrhizal fungi, trees were girdled in the middle of the growth season.The disruption of carbon transport was controlled (C) 2009 Blackwell Publishing Ltd, Plant, Cell and Environment, 32, 992-1003 in an accompanying experiment by studying ${ }^{14} \mathrm{C}$ below ground allocation. The field study was set up to test the following hypotheses: (1) low plant carbon productivity will lead to changes in the ectomycorrhizal fungi community composition, if the fungi have different carbon demand; (2) the relative abundance of ectomycorrhizal colonization will not change if beech was obligatorily ectomycorrhizal; and (3) alternatively, if ectomycorrhizas were controlled by plant carbon productivity, decreased colonization is expected as a consequence of carbon limitation.

\section{MATERIALS AND METHODS}

\section{Plants, growth conditions, experimental treatments and harvest}

Two-year-old beech trees (F.sylvatica,L.,provenance North Germany, seed lot 81009) obtained from a nursery (Forstbaumschule Billen, Bösinghausen, Germany) were planted in March 2003 into compost soil in the area of the Forest Botanical Garden (geographical coordinates: 51 $31^{\prime} 48^{\prime \prime} \mathrm{N}$, 956'39"E; University of Göttingen, Göttingen, Germany). A total of 160 trees were planted at a density of $0.4 ¥ 0.2 \mathrm{~m}$. The area was divided in four plots with plastic barriers.Half the number of trees was shaded with nets (Hermann-Meyer KG,Rellingen,Germany) yielding 65\% shading in 2003 and 2004. In 2005 and 2006, a second net was installed decreasing ambient light to about $10 \%$ of incident irradiation.

Compost soil with a $\mathrm{pH}$ of 7.2 and the following nutrient elements concentrations ( $\mathrm{mg} \mathrm{g}^{-1}$ dry mass): $\mathrm{N}: 6, \mathrm{P}: 1.3, \mathrm{~K}: 6.8$, Ca: 30.4, Mg: 5.7, and S: 1.23 was obtained from Kompostwerk $\mathrm{GmbH}$ (Niederorla, Germany). The mean seasonal temperatures (and sum of precipitation) in the growth phase from 1st of April to 30 th of September were $15.7^{\circ} \mathrm{C}(280 \mathrm{~mm})$ in $2003,14.2^{\circ} \mathrm{C}$ (404 mm) in $2004,14.5^{\circ} \mathrm{C}(328 \mathrm{~mm})$ in 2005 and $15.4{ }^{\circ} \mathrm{C}$ (446 $\mathrm{mm}$ ) in 2006. When necessary during dry hot periods, all trees were irrigated with tap water.

On the 30th of June 2006, half of the plants of each light level were girdled at the main stem at half of the distance between the bottom and the first side branches. A 2-cmwide strip of bark was removed around the stem initially retaining a small connecting piece (ca. $5 \mathrm{~mm}$ width). Since no effects on photosynthesis were found after 4 weeks of girdling, the connecting bark strap was removed on 7 August. Stem radial diameter was measured once a week at a marked position at the stem basis.

No plant died because of girdling; however, some plants had died between 2003 and 2006. Thus, between 30 and 40 plants were available per treatment. Plant height was determined by measuring the length from the stem basis to the top of the leader shoot.Twenty trees of similar height were selected in each treatment for further analysis. Ten of these plants were harvested 5 weeks (first week of August), and a further 10 plants 10 weeks after girdling (second week of September). Immediately after harvest, aliquots of fresh tissues from five plants per treatment were frozen in liquid nitrogen for further biochemical analysis. Root systems of five plants per treatment and harvest date were 
stored at $4{ }^{\circ} \mathrm{C}$ for mycorrhizal analysis. All plants were used for biomass determination after separation into leaves, stem and branches, coarse and fine roots. Dry mass was determined after drying for 2 weeks at $40{ }^{\circ} \mathrm{C}$.

\section{Photosynthesis and chlorophyll fluorescence measurements}

Gas exchange was determined with an infrared gas analyser (HCM-1000, Walz, Effeltrich, Germany) at saturating photosynthetically active radiation (PAR) of $800 \mathrm{mmol}$ light quanta $\mathrm{m}^{-2} \mathrm{~s}^{-1}$ at $20{ }^{\circ} \mathrm{C}$, and $65 \%$ relative air humidity on five plants per treatment 1 week before harvest in September. Light curves were recorded by increasing the light intensity stepwise from zero to $1200 \mathrm{mmol}$ light quanta $\mathrm{m}^{-2} \mathrm{~s}^{-1}$. Measurements were performed in July on non-girdled, shade- and sunacclimated plants ( $n=5$ per treatment).Photosynthesis (PS) curves were fitted by exponential growth equations (software Origin7, OriginLab Corporation, Northampton, MA, USA). PAR was measured approximately twice a week between 10 a.m. and 2 p.m. from July to mid-September at the level of the upper leaves of five plants per treatment.

The quantum yield of photochemistry was determined regularly from July until harvest in September (MINIPAM, Walz, Effeltrich, Germany) at ambient conditions as $\left(F_{\mathrm{m}}{ }^{\prime}-\right.$ $\left.F_{\mathrm{o}}\right) / F_{\mathrm{m}}{ }^{\prime}$ (Maxwell \& Johnson 2000) ( $n=5$ plants per treatment).

\section{Biochemical methods and element analysis}

For pigment analysis, frozen leaves were ground with a pestle and mortar in liquid nitrogen to a fine powder, extracted in $80 \%$ acetone and the absorption of the chlorophyll $a$, chlorophyll $b$ and carotenoids was determined spectrophotometrically as described by Lichtenthaler \& Wellburn (1983).

Soluble carbohydrates were determined enzymatically in extracts of leaf and root tissue yielding glucose, fructose and sucrose concentrations (Beutler 1978). Starch was converted to glucose by amyloglucosidase and measured in glucose units.

Nutrientelementsweremeasuredafterpressuredigestion of dry leaf and root tissues in $65 \%$ nitric acid by inductively coupled plasma optical emission spectrometry (Spectro Analytical Instruments, Kleve, Germany) (Heinrichs et al. 1986).Carbon and nitrogen were determined in an Elemental Analyzer (Carlo Erba, Rodano, Italy).All analyses were conducted in tissues of five plants per treatment.

\section{Mycorrhizal analysis}

Harvested roots were stored at $4{ }^{\circ} \mathrm{C}$ and observed within 2 weeks. They were soaked in water and washed gently to remove the adhering soil. Five fine root samples per plant with 200 to 300 root tips each were observed using a dissecting microscope (Stemi SV 11, Zeiss, Jena, Germany).

Root tips were counted and recorded as vital mycorrhizal, vital non-mycorrhizal and dead root tips. To control these classifications, selected root tips were embedded (Gafur et al. 2004) and anatomically inspected (data not shown). Relative EM colonization was calculated as EM/(EM + vital non mycorrhizal root tips). Mycorrhizal root tips were divided into morphotypes according to a simplified system of Agerer (1987-2006) based on morphological characters like colour of the mantle, branching and appearance and properties of emanating hyphae and rhizomorphs. All morphotypes were documented with digital photos (Coolpix 4500, Nikon, Düsseldorf, Germany).

To identify EM species DNA was extracted from aliquots of the morphotypes, which had been stored at $-80{ }^{\circ} \mathrm{C}$. Frozen EM root tips were ground in a mill (Typ MM 2, Retsch, Haan, Germany) and extracted using the DNeasy® Plant Mini Kit 50 (Qiagen, Hilden, Germany) following the instruction of the manufacturer. The ITS (internal transcribed spacer) region was amplified by PCR using the primers ITS 1 ( $5^{\prime}$ - TCC GTA GGT GAA CCT GCG G-3') and ITS 4 (5'-TCC TCC GCT TAT TGA TAT GC-3') (White et al. 1990). PCR was performed according to Landeweert et al. (2005). PCR products were cloned in the pGEM $^{\circledR}$-T System I vector (Promega, Madison, WI, USA) and transformed into electrocompetent $E$. coli cells (TOP TEN, Invitrogen, Carlsbad, CA, USA). Positive clones were sequenced (ABI Prism 3100 Genetic Analyser, 36 cm capillary, Matrix Pop 6, Applied Biosystems Foster City, CA, USA). The sequences were compared with those present in UNITE database (Kõljalg et al. 2005, http://unite.ut. ee/) and NCBI database (http://www.ncbi.nlm.nih.gov/). UNITE is a databank for ectomycorrhizal fungi, which requires deposition of specimen and therefore is usually more reliable than NCBI, which is a general database for all kinds of sequences.

\section{${ }^{14} \mathrm{C}$ glucose below ground allocation}

In an independent experiment, one year old beech plants grown in pots in a greenhouse,were transferred to a growth cabinet and maintained under $16 \mathrm{~h}$ light $(200 \mathrm{mmol}$ photosynthetic active radiation $) / 8 \mathrm{~h}$ darkness, $20{ }^{\circ} \mathrm{C}$ and 60 to $70 \%$ relative air humidity. Six plants were girdled $3 \mathrm{~cm}$ above soil level by removing an about $1-\mathrm{cm}$-broad strip of bark. Further six plants remained intact.After $1 \mathrm{~h}$ the third fully expanded top leaf was rubbed with silicium carbid ('Carborund', ESK-SIC GmbH, Frechen, Germany) and immediately supplied with $50 \mathrm{ml} 5 \mathrm{mCi}$ glucose (Moravek Biochemicals, Brea, CA, USA). The plants were watered regularly and harvested after 3 and $6 \mathrm{~d}$. The plants were separated into the following fractions: coarse roots, fine roots, a 1-cm-long stem piece directly below the girdle (separated in bark and wood), a 1-cm-long stem pieces directly above the girdle (separated in wood and bark) and residual materials. The plant materials were dried for $24 \mathrm{~h}$ at $70{ }^{\circ} \mathrm{C}$, and the exact mass of each plant fraction was determined.The samples were combusted in a biological oxidizer (Ox500, Zinsser, Frankfurt, Germany) using the carbon-14 standard for sample oxidizers from Amersham International (Plc., Amersham, UK) as the standard. Resulting ${ }^{14} \mathrm{CO}_{2}$ was trapped in a liquid scintillation cocktail (Zinsser Analysis Oxysolve TC-400, Zinsser Analytic, Frankfurt, Germany). The radioactivity was measured in a liquid (C) 2009 Blackwell Publishing Ltd, Plant, Cell and Environment, 32, 992-1003 
scintillation analyser (Tri-Carb 2800 TR, PerkinElmer Life Sciences, Wellesley, MA, USA). Total radioactivity was determined in each of the fractions and related to the applied amount of radioactivity: tissue label $(\%)=$ (total activity in a plant fraction) $* 100 /$ (total applied radioactivity).

\section{Data analysis}

The following diversity indices were calculated: species richness $H(\max )=\ln$ (number of all species), ShannonWiener index, $H^{\prime}$ $=-S p_{i} \ln p_{i}$, where $p$ is the probability of the species $i$, and Evenness $=H^{\prime} / H(\max )($ Shannon \& Weaver 1949). The sampling unit 'plant' served as the basis for calculating these indices, if not indicated differently.

Statistical analysis was performed using Statgraphics Plus 3.0 (StatPoint, Inc., St Louis, MO, USA). The experiment had a randomized block design with the factors light and girdling. Data in figures and table are indicated are as means ( $1 \mathrm{SE}$ ) when assumptions for normality were met (Shapiro-Wilks Test W, $P<$ 0.05 ) and were compared by anova and a multiple range test (LSD). If assumptions of normality were not met, data were log transformed before anova. Means were considered to be significantly different from each other, if $P \quad 0.05$. Significant differences are indicated in tables and figures by different letters. Regression curves were plotted with the programme Origin 7G (Origin Lab, Corporation, Northhampton, MA, USA).

\section{RESULTS}

\section{Light limitations affect growth but not carbon storage in roots}

To limit carbon availability, beech trees were grown for four seasons under limiting light. Maximum rates of lightsaturated

\begin{tabular}{|c|c|c|c|c|c|}
\hline & Sun control & Sun girdled & Shade control & Shade girdled & $\begin{array}{l}\text { Table 1. Photosynthesis, growth, biomass, pigments } \\
\text { and carbohydrates in beech (Fagus }\end{array}$ \\
\hline $\operatorname{PAR}\left(\mathrm{mmol} \mathrm{m} \mathrm{m}^{-2} \mathrm{~s}^{-1}\right)^{\mathrm{a}}$ & $980123 b$ & $990128 b$ & $203 a$ & $192 \mathrm{a}$ & $\begin{array}{l}\text { sylvatica) grown in full sun or with limited } \\
\text { light }\end{array}$ \\
\hline Photosynthesis (estimated) & $6.050 .28 b$ & $6.140 .23 b$ & $0.210 .07 \mathrm{a}$ & $0.220 .11 \mathrm{a}$ & \\
\hline Photosynthesis (max) & $8.851 .49 \mathrm{~b}$ & $9.020 .39 b$ & $2.210 .28 \mathrm{a}$ & $2.110 .49 \mathrm{a}$ & \\
\hline Chl $(a+b)\left(\mathrm{mmol} \mathrm{g}^{-1} \mathrm{FW}\right)$ & $2061312 \mathrm{a}$ & $1906105 \mathrm{a}$ & $4025332 b$ & $3729266 b$ & \\
\hline Leader shoot height ${ }^{\mathrm{a}}(\mathrm{m})$ & $0.880 .34 b$ & $0.940 .38 b$ & $0.610 .20 \mathrm{a}$ & $0.560 .16 \mathrm{a}$ & \\
\hline Stem increment ${ }^{\mathrm{a}}$ (\%o per week) & $15.85 .3 b$ & $12.05 .9 \mathrm{~b}$ & $8.44 .9 \mathrm{a}$ & $3.83 .1 \mathrm{a}$ & \\
\hline $\operatorname{Biomass}^{\mathrm{a}}(\mathrm{g})$ & $664131 b$ & $680146 b$ & $348 \mathrm{a}$ & $262 \mathrm{a}$ & \\
\hline Root/shoot & $0.550 .06 b$ & $0.350 .03 \mathrm{a}$ & $0.590 .03 b$ & $0.490 .02 b$ & \\
\hline NS carbon (mg whole $\operatorname{root}^{-1}$ ) & $3901157 c$ & $2850275 b$ & $30921 \mathrm{a}$ & $14319 a$ & \\
\hline
\end{tabular}

NS, non-structural.

Estimated photosynthesis $\left(\mathrm{mmol} \mathrm{CO}_{2} \mathrm{~m}^{-2} \mathrm{~s}^{-1}\right)$ was calculated on the basis of the equations for the light response curves (see text) and repeated light measurements (PAR*) from July to September. Maximum photosynthesis was determined in September at saturating photosynthetically active radiation of $800 \mathrm{mmol}$ quanta $\mathrm{m}^{-2} \mathrm{~s}^{-1}$. Non-structural carbohydrates were determined as the sum of starch,glucose,fructose and sucrose in fine and coarse roots $(n=5,1 \mathrm{SE})$. Different letters in rows indicate significant differences at $P 0.05$. photosynthesis were about 2 and $9 \mathrm{mmol} \mathrm{CO}_{2} \mathrm{~m}^{-2} \mathrm{~s}^{-1}$ in shade and sun acclimated plants, respectively, in the fourth season (Table 1). Chlorophyll concentrations showed typical adaptations to shade and sun, respectively (Table 1). Under ambient light net photosynthesis (NP) rates were estimated on $\left.=6.59+\left(-8.12 \mathrm{e}^{(\mathrm{PAR} /-109.75)}\right), r^{2}=0.9856\right]$ and shadeacclimated plants $\left[\mathrm{NP}=2.42+\left(-3.11 \mathrm{e}^{(\mathrm{PAR} / 56.20)}\right), r^{2}=\right.$ 0.9848]. Sun-acclimated plants maintained photosynthetic activities close to the maximum, whereas shade-acclimated plants operated just above the light compensation point of 13 mmol light quanta $\mathrm{m}^{-2} \mathrm{~s}^{-1}$ (Table 1). The photosynthetic limitation resulted in significantly diminished growth and biomass production in shade-grown compared with sun-grown trees but not in differences in biomass allocation between above and below ground plant tissues as indicated by similar root-toshoot ratios of sun- and shade-acclimated plants (Table 1).

Soluble carbohydrate concentrations calculated as the sum of glucose, fructose and sucrose of sun-acclimated leaves were higher than those of shade-acclimated leaves, whereas the foliar starch concentrations were unaffected (Fig. 1a,b). Soluble carbohydrates of coarse and fine roots as well as starch concentrations of fine roots of sunacclimated plants were similar to those of shade-acclimated plants (Fig. 1c,e,f).The starch concentrations in coarse roots of shade-acclimated plants were even higher than those of sun-acclimated plants (Fig. 1d). This indicates that the basis of light response curves of sun-acclimated plants [NP

a Data were log-transformed for statistical analysis. 

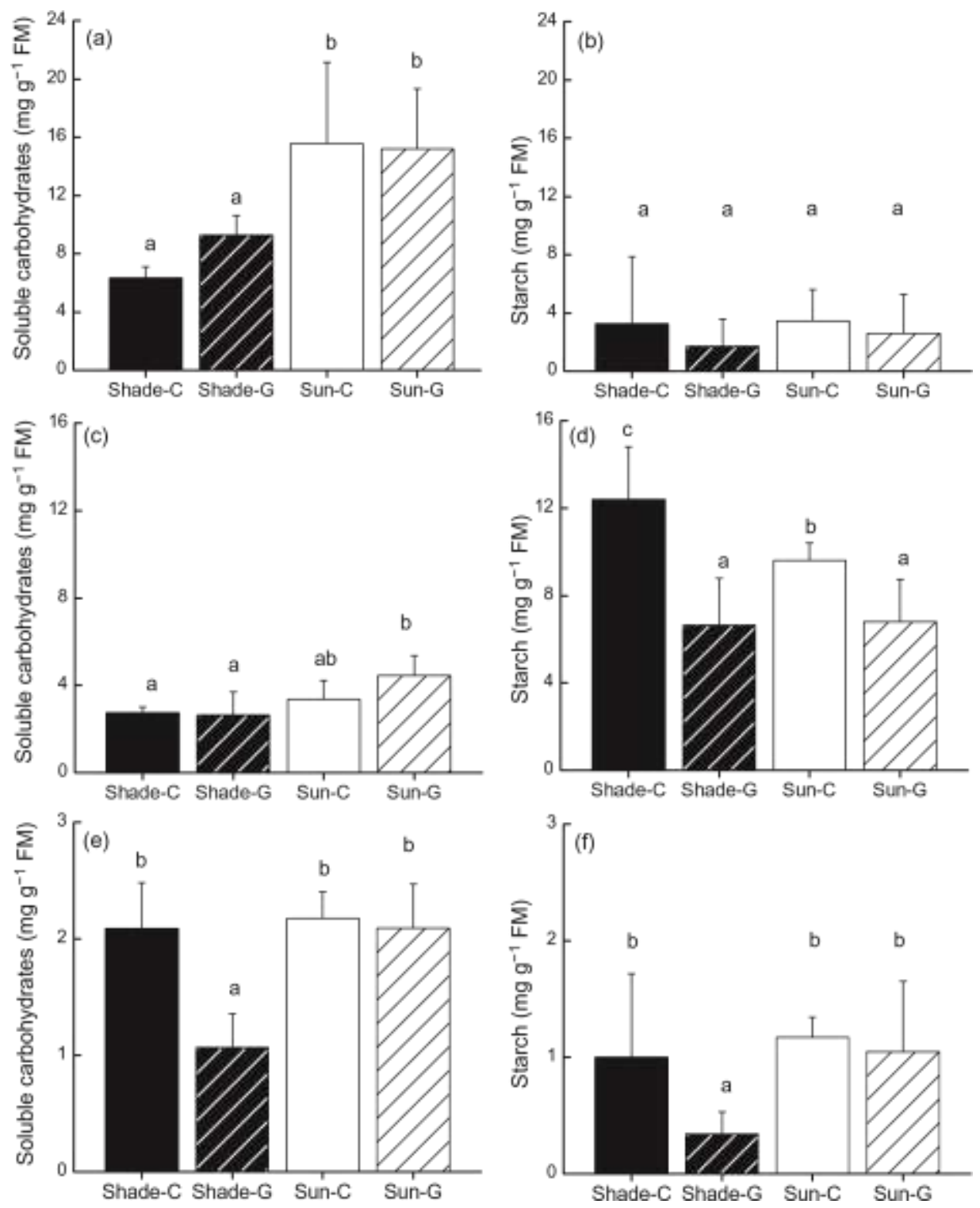

Figure 1. Soluble carbohydrates and starch in leaves (a, b), coarse roots (c, d) and fine roots (e, f) of beech (Fagus sylvatica) grown in full sun or with limited light. Plants were grown under shading nets with about $10 \%$ of incident radiation (black bars) or in full sun (white bars) for 4 years. Half of the plants of each light level were girdled (hatched bars). Soluble carbohydrates were determined as the sum of glucose, fructose and sucrose in September. Data indicate means $(n=5,1 \mathrm{SE})$. Different letters in rows indicate significant differences at $P 0.05$.

despite severe light limitation of photosynthesis, below ground storage pools of carbon were not depleted.

\section{Girdling has no immediate implications for photosynthesis but leads to depletion in root carbon storage pools}

To limit flux of recently fixed carbon to the roots, a subset of trees from each light regime was girdled in the mid of the growth season, initially partly and after five weeks completely. Girdling had no negative effect on quantum yield of photochemistry (not shown), $\mathrm{CO}_{2}$ assimilation or gross biomass but caused a loss in root relative to shoot biomass in sunacclimated plants (Table 1). Girdling did not affect carbohydrate concentrations in the leaves (Fig. 1a,b).

Since we had expected accumulation of carbohydrates and feed-back inhibition of photosynthesis in response to girdling, we wondered whether the girdle could be circumvented by radial transport of carbohydrates into the xylem ray parenchyma cells, transport in radial and axial ray cells with possible reallocation into the bark below the girdle. To investigate this possibility, a radioactive labelling experiment was conducted under controlled conditions.A mature top leaf was fed with ${ }^{14} \mathrm{C}$ glucose and the relative distribution of the label above and below the girdle and 
in the root system was analysed after 3 and $7 \mathrm{~d}$. After these exposure comparison with trees grown in full sun light (Fig. 2b). Girdling had no influence on ectomycorrhizal abundance but resulted in a

Table 2. Carbon transport to roots after girdling

\begin{tabular}{|c|c|c|c|c|c|c|c|c|}
\hline Treatment & $\begin{array}{l}\text { Chase time } \\
\text { (d) }\end{array}$ & $\begin{array}{l}\text { Wood (a) } \\
(\%)\end{array}$ & $\begin{array}{l}\text { Bark (a) } \\
(\%)\end{array}$ & $\begin{array}{l}\text { Wood (b) } \\
(\%)\end{array}$ & $\begin{array}{l}\text { Bark (b) } \\
(\%)\end{array}$ & $\begin{array}{l}\text { Coarse roots } \\
(\%)\end{array}$ & $\begin{array}{l}\text { Fine roots } \\
(\%)\end{array}$ & $\begin{array}{l}\text { Through flow } \\
(\%)^{\mathrm{a}}\end{array}$ \\
\hline Control & 3 & 0.130 .05 & 0.270 .07 & 0.170 .03 & 0.350 .08 & 13.852 .98 & 4.331 .07 & 0.121 \\
\hline Girdle & 3 & $\begin{array}{lll}0.70 & 0.22\end{array}$ & 1.090 .12 & $\begin{array}{lll}0.06 & 0.02\end{array}$ & $\begin{array}{lll}0.04 & 0.01\end{array}$ & $\begin{array}{lll}0.00 & 0.00\end{array}$ & $\begin{array}{lll}0.05 & 0.02\end{array}$ & 0.033 \\
\hline Control & 7 & $\begin{array}{lll}0.06 & 0.01\end{array}$ & $0.17 \quad 0.07$ & $\begin{array}{lll}0.05 & 0.01\end{array}$ & $\begin{array}{lll}0.18 & 0.08\end{array}$ & 10.003 .78 & 4.761 .21 & 0.128 \\
\hline Girdle & 7 & 0.990 .51 & 1.860 .64 & $0.07 \quad 0.01$ & $\begin{array}{ll}0.05 & 0.02\end{array}$ & $\begin{array}{lll}0.01 & 0.00\end{array}$ & $0.04 \quad 0.01$ & 0.000 \\
\hline$P$ (girdle) & 0.026 & 0.005 & 0.069 & 0.006 & 0.001 & 0.001 & nd & \\
\hline$P$ (time) & 0.693 & 0.337 & 0.026 & 0.218 & 0.447 & 0.800 & nd & \\
\hline Interaction & 0.525 & 0.213 & 0.013 & 0.167 & 0.446 & 0.792 & nd & \\
\hline
\end{tabular}

${ }^{a}$ Radioactivity in through flow was determined a pooled sample.

Data indicate fraction of radioactivity (\%) recovered in wood, bark, coarse and fine roots of young beech (Fagus sylvativa) trees after ${ }^{14} \mathrm{C}$ glucose feeding via a leaf. Six trees were girdled $1 \mathrm{~h}$ before application of ${ }^{14} \mathrm{C}$ glucose to the leaf and six trees were kept as controls. Total radioactivity applied to the leaf was set as $100 \%$. Trees were maintained in a growth cabinet during the labelling and chase phase and harvested 3 and $7 \mathrm{~d}$ after labelling $(n=3$ per time point and treatment. (a) refers to wood and bark directly above and (b) below the girdle.

Controls were harvested at the corresponding positions.

times, coarse and fine roots of non-girdled controls showed a strong accumulation of the applied label, whereas in the root system of girdled trees only traces were detected (Table 2).A sizable fraction of the label was also present in the throughflow of the irrigation water of non-girdled trees, whereas only traces were present in the irrigation water of girdled trees (Table 2). Along the transport path, girdled trees showed an accumulation of the label in xylem and bark above but a strong decrease below the girdle (Table 2). In control trees, no gradient was observed at corresponding positions of the stem. This shows that although girdling does not interrupt belowground carbon allocation completely, the fraction of carbohydrates reaching the belowground compartment was only marginal accounting for $0.01 \%$ and $0.25 \%$ in coarse and fine roots compared with nongirdled controls.

In the field experiment, the concentration of nonstructural carbon in roots, especially that of starch in coarse roots of shaded plants, decreased as a consequence of girdling (Fig. 1d). As the replenishment of carbon resource in the girdled trees was negligible, carbon consumption rates of the roots can be assessed. Using biomass data for fine and coarse roots, the total pool sizes of the metabolically active carbon fraction (sum of glucose,fructose,sucrose and starch) were calculated (Table 1). Within 10 weeks, girdled sun- and shade-grown beech trees lost $27 \%$ and $54 \%$, respectively, of the total carbohydrates compared with nongirdled controls.

\section{Light limitation and girdling have different impact on mycorrhizal abundance and diversity}

Fine roots of beech trees grown under full sun light showed about twice higher fractions of dead root tips than shadeacclimated trees (Fig. 2a). The vital root tips of shadeacclimated trees displayed very low colonization with ectomycorrhizal fungi in trend towards higher root mortality in roots of shade-acclimated trees (Fig. 2a,b). The maintenance of ectomycorrhizal abundance and proportion of colonization was unexpected and suggested that the observed decreases in root carbohydrate storage were not only utilized for self support of root structures but also to feed mycorrhizas.

To find out whether differences in growth and plant biomass production as well as girdling affected the composition of the fungal communities, morphotyping was combined with sequencing of the ITS region to identify fungi and to obtain quantitative data on root colonization. We have been able to obtain sequence information for 11 out of initially 20 different fungal morphotypes. The 11 sequences belonged to 7 different species yielding a total number of 16 putatively different fungal species forming ectomycorrhizas with the beech trees in this experiment (Supplementary files 1A \& B). We can not exclude that these numbers overestimated species richness because we have not been able to obtain PCR products for all morphotypes. However, the non-sequenced morphotypes were dissimilar (Supplementary file 1B). Based on these species numbers, total species richness at roots of shade- and sunacclimated beech trees was 3 and 14, respectively, and not affected by girdling (Supplementary file 1C). Only one species, an uncultured ECM (MT1), occurred at root tips of all treatments.

Shannon-Wiener indices $\left(H^{\prime}\right)$ were calculated for each root sample (mean root sample $=98857$ vital root tips, $n=5$ per experimental variable). $H^{\prime}$ was significantly higher for ectomycorrhizas at roots of sun-acclimated than for those of shade-acclimated trees (Fig. 2c). Girdling had no significant influence on $H^{\prime}$ (Fig. 2c). Overall, these results show that if there were more root tips amenable for mycorrhizal colonization, they were colonized by more different fungal species and not by more fungi of the same species.

To find out whether changes in community composition observed at roots of light-limited and sun-exposed or girdled 
and non-girdled trees affected dominance structures, we calculated evenness. There were no significant differences between the treatments. Mean Evenness across
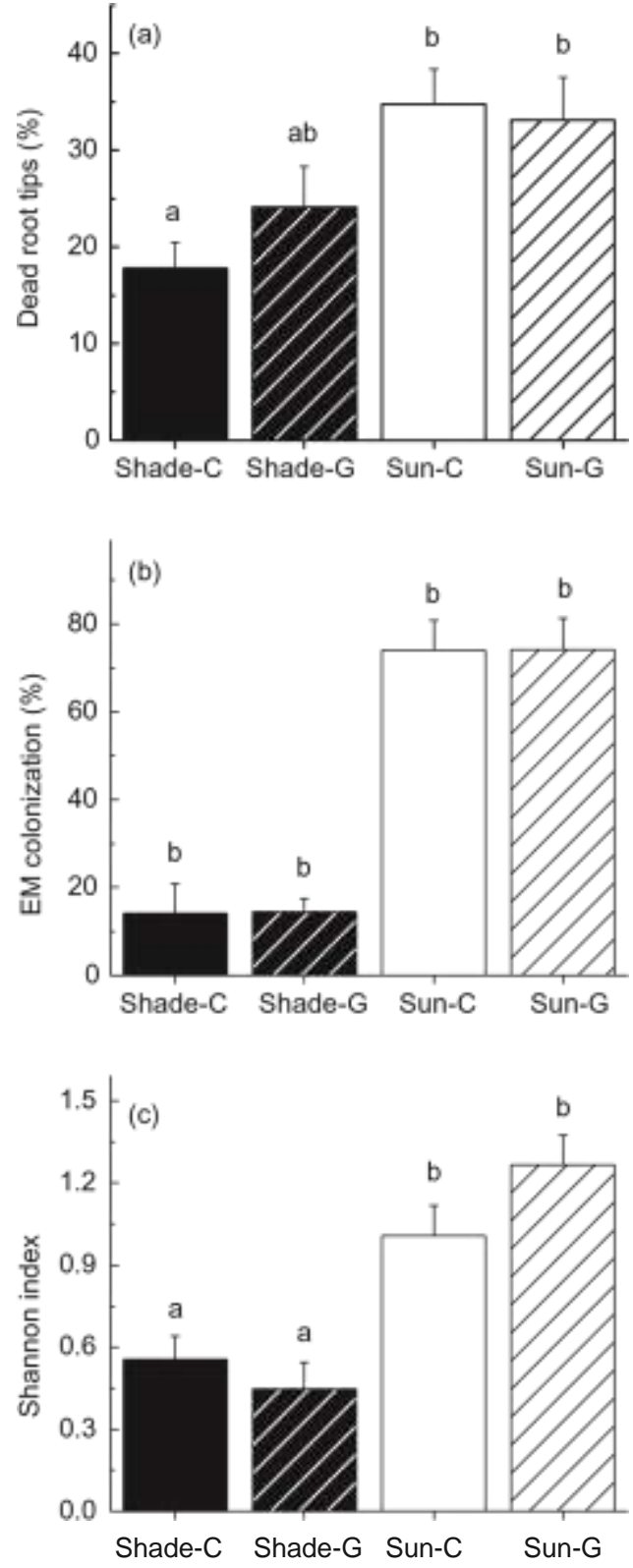

Figure 2. Proportion of dead root tips (a), mycorrhizal colonization of vital roots tips (b) and Shannon-Wiener index $H^{\prime}$ of mycorrhizal roots of beech (Fagus sylvatica) grown in full sun or with limited light. Plants were grown under shading nets with about $10 \%$ of incident radiation (black bars) or in full sun (white bars) for 4 years. Half of the plants of each light level were girdled (hatched bars). Measurements were taken in August and September. As no significant differences were found between data, means of both sampling dates are shown $(n=10,1 \mathrm{SE})$. Different letters in rows indicate significant differences at $P 0.05$.

all treatments was 0.710 .02 . We conclude that beech trees showed a surprisingly stable pattern of dominance structures of their ectomycorrhizal communities, although the colonization of the roots tips varied strongly (Fig. 2) and the species composition changed with light level and girdling (Supplementary files).

\section{Mycorrhizal abundance and diversity in relation to beech productivity and nutrition}

As low rates of mycorrhizal colonization can lead to insufficient nutrient uptake, which in turn may affect growth, nutrient element concentrations were determined in fine roots and leaves (Table 3). The nitrogen concentrations of leaves and roots of the shade-grown plants were higher than those of sun-exposed plants (Table 3). The concentrations of other nutrients were more variable than those of nitrogen. Roots of girdled, sun-exposed trees contained more $\mathrm{P}$ than roots of girdled,shade-exposed trees (Table 3). In roots of non-girdled trees, differences between the harvest in August and the harvest in September were observed, but there were no effects of shading (Table 3). Other nutrients were usually higher or unaffected in shadecompared with sunexposed plants (Table 3 ). We conclude that the productivity of shade-exposed plants was only limited by light and not by nutrients.Therefore, mycorrhizal colonization and diversity of shaded plants were dependent on plant productivity and not vice versa.

We plotted biomass as independent and diversity $H^{\prime}$ as dependent variable to investigate the relationship between these parameters (Fig. 3). The best fit was obtained for an exponential function (Fig. 3). A similar relationship was obtained for biomass and mycorrhizal colonization rates (Fig. 3) because $H^{\prime}$ was increased in samples with high mycorrhizal abundance (Fig. $2 b, c)$.

\section{DISCUSSION}

\section{Beech productivity governs ectomycorrhiza abundance and diversity}

Understanding the links between aboveground and belowground communities is one of the challenging tasks of ecology (Bardgett et al. 2005). In forest ecosystems, analysis of the relationship between beech productivity and diversity of the associated root fungi is hampered by soil patchiness, nutrient availability, tree age and other variables. To test the hypothesis that plant productivity was the reason for and not the result of high ectomycorrhizal diversity, our study was conducted under conditions where these factors were excluded. A draw-back of such experimental conditions is that the fungal community and colonization found at the roots of beech were not typical of a forest situation. Beech roots are usually almost completely (99\%) colonized by a highly diverse ectomycorrhizal flora (Taylor, Martin \& Read 2000; Rumberger et al. 2004; Buée, Vairelles \& Garbaye 2005; Grebenc \& Kraigher 2007). Repeated samplings across different seasons revealed up to 90 different morphotypes on beech roots in an undisturbed oldgrowth forest (Pena et al., unpublished results). But species numbers depend on the sampling scheme (Taylor 2002).For example, beech roots sampled once along a north-south transect at sites differing in $\mathrm{N}$ pollution showed between 11 and 20 different morphotypes, which is within the range of morphotypes found in our study. 
Similar figures were also reported for beech grown on relatively sandy soil

Table 3. Nutrient element concentrations ( $\mathrm{mg} \mathrm{g}^{-1}$ dry mass) in leaves and roots of beech (Fagus sylvatica) grown in full sun or shade

\begin{tabular}{|c|c|c|c|c|c|c|c|}
\hline \multirow[b]{2}{*}{ Tissue } & \multirow[b]{2}{*}{ Element } & \multicolumn{2}{|l|}{ 1st harvest } & \multicolumn{2}{|l|}{ 2nd harvest } & \multicolumn{2}{|l|}{ 2nd harvest } \\
\hline & & Shade control & Sun control & Shade control & Sun control & shade giraled & Asun giraled \\
\hline Leaf & $\mathrm{C}$ & $458.39 .6 \mathrm{c}$ & $473.64 .1 \mathrm{e}$ & $433.72 .0 \mathrm{a}$ & $464.52 .9 \mathrm{~cd}$ & $445.12 .7 \mathrm{~b}$ & $465.75 .4 d$ \\
\hline Leaf & $\mathrm{N}$ & $26.200 .64 \mathrm{~cd}$ & $21.692 .03 \mathrm{a}$ & $27.982 .71 \mathrm{~d}$ & $23.082 .38 \mathrm{ab}$ & $25.102 .10 \mathrm{bc}$ & $=20.931 .51 \mathrm{a}$ \\
\hline Leaf & $\mathrm{P}$ & $0.950 .29 \mathrm{a}$ & $1.210 .07 \mathrm{ab}$ & $1.510 .32 \mathrm{c}$ & $1.350 .18 b c$ & $=1.370 .07 b c$ & $\begin{array}{l}1.24 \\
0.19 b c\end{array}$ \\
\hline Leaf & K & $8.093 .75 b$ & $4.510 .51 \mathrm{a}$ & $15.391 .89 \mathrm{~d}$ & $6.461 .09 \mathrm{ab}$ & $12.292 .53 \mathrm{c}$ & $4.950 .69 \mathrm{a}$ \\
\hline Leaf & $\mathrm{S}$ & $1.210 .42 \mathrm{a}$ & $1.240 .08 \mathrm{a}$ & $1.790 .18 \mathrm{c}$ & $1.520 .11 b c$ & $=1.650 .17 \mathrm{c}$ & $\begin{array}{l}1.27 \\
0.180 \mathrm{ab}\end{array}$ \\
\hline Leaf & $\mathrm{Ca}$ & $8.823 .91 \mathrm{a}$ & $10.192 .41 \mathrm{a}$ & $15.212 .23 b$ & $11.162 .96 \mathrm{a}$ & $10.011 .0 \mathrm{a}$ & $10.431 .66 \mathrm{a}$ \\
\hline Leaf & $\mathrm{Mg}$ & $2.170 .78 \mathrm{a}$ & $2.510 .29 \mathrm{ab}$ & $3.050 .67 \mathrm{~b}$ & $2.320 .32 \mathrm{a}$ & $3.010 .21 b$ & $2.160 .44 a$ \\
\hline Leaf & Mn & $0.02 \quad 0.01 \mathrm{ab}$ & $0.020 .01 b c$ & $0.030 .01 \mathrm{~d}$ & $0.020 .01 b c$ & $0.030 .01 \mathrm{~cd}$ & $0.010 .01 \mathrm{a}$ \\
\hline Leaf & $\mathrm{Fe}$ & $0.440 .23 b c$ & $0.190 .09 \mathrm{a}$ & $0.810 .27 d$ & $0.310 .09 \mathrm{ab}$ & $0.560 .19 \mathrm{c}$ & $0.180 .08 \mathrm{a}$ \\
\hline Root & $\mathrm{C}$ & $465.55 .4 \mathrm{bc}$ & $454.0 \quad 13.4 \mathrm{a}$ & $468.25 .9 \mathrm{c}$ & $455.312 .8 \mathrm{ab}$ & $475.23 .4 c$ & $465.61 .6 \mathrm{bc}$ \\
\hline Root & $\mathrm{N}$ & $16.972 .28 \mathrm{~b}$ & $11.181 .56 \mathrm{a}$ & $17.131 .73 b$ & $11.830 .52 \mathrm{a}$ & $16.274 .33 b$ & $11.391 .16 \mathrm{a}$ \\
\hline Root & $\mathrm{P}$ & $1.160 .57 \mathrm{a}$ & $1.620 .66 \mathrm{ab}$ & $1.460 .67 \mathrm{ab}$ & $1.320 .29 \mathrm{a}$ & $1.250 .39 \mathrm{a}$ & $2.170 .93 b$ \\
\hline Root & $\mathrm{K}$ & $3.931 .75 \mathrm{a}$ & $3.780 .97 \mathrm{a}$ & $5.191 .38 \mathrm{a}$ & $4.130 .27 \mathrm{a}$ & $5.001 .61 \mathrm{a}$ & $4.180 .63 a$ \\
\hline Root & $\mathrm{S}$ & $1.590 .65 \mathrm{c}$ & $1.070 .34 \mathrm{ab}$ & $1.320 .13 b c$ & $1.080 .19 \mathrm{ab}$ & $1.070 .11 \mathrm{ab}$ & $0.970 .19 \mathrm{a}$ \\
\hline Root & $\mathrm{Ca}$ & $13.425 .48 \mathrm{~b}$ & $9.592 .91 \mathrm{a}$ & $9.531 .26 \mathrm{a}$ & $9.262 .39 \mathrm{a}$ & $9.230 .81 \mathrm{a}$ & $8.752 .11 \mathrm{a}$ \\
\hline Root & $\mathrm{Mg}$ & $1.860 .78 \mathrm{a}$ & $1.980 .43 \mathrm{a}$ & $1.810 .27 \mathrm{a}$ & $1.890 .36 \mathrm{a}$ & $1.730 .38 \mathrm{a}$ & $1.880 .34 \mathrm{a}$ \\
\hline Root & $\mathrm{Mn}$ & $0.070 .03 \mathrm{ab}$ & $0.07 \quad 0.02 \mathrm{~b}$ & $0.05 \quad 0.01 \mathrm{ab}$ & $0.05 \quad 0.02 \mathrm{ab}$ & $0.05 \quad 0.02 \mathrm{a}$ & $0.050 .01 \mathrm{a}$ \\
\hline Root & $\mathrm{Fe}$ & $1.450 .67 \mathrm{abc}$ & $1.850 .51 \mathrm{c}$ & $1.010 .24 \mathrm{a}$ & $1.680 .83 \mathrm{bc}$ & $=1.050 .46 \mathrm{ab}$ & $\begin{array}{l}1.14 \\
0.31 \mathrm{ab}\end{array}$ \\
\hline
\end{tabular}

Data indicate means $(n=5, \mathrm{SD})$ of harvest 1 (first week in August) and harvest 2 (second week in September). Different letters in rows indicate significant differences at $P 0.05$.

(Rumberger et al. 2004). We can not exclude that the nutrient rich compost soil, which we used to avoid nutrient limitations affected diversity and root colonization. For example, the unusually high number and abundance of Tuber species might have been caused by the relatively high soil $\mathrm{pH}$ (Pruett, Bruhn \& Mihail 2008). There is evidence that ectomycorrhizal species richness is suppressed by high nitrogen availability (Jonsson, Anders \& Tor-Erik 2000; Peter et al. 2001; Lilleskov et al. 2002; Carfrae et al. 2006; Parrent et al. 2006; Avis, Mueller \& Lussenhop 2008), although the development of species rich nitrophilic communities has also been observed (Kranabetter, Durall \&

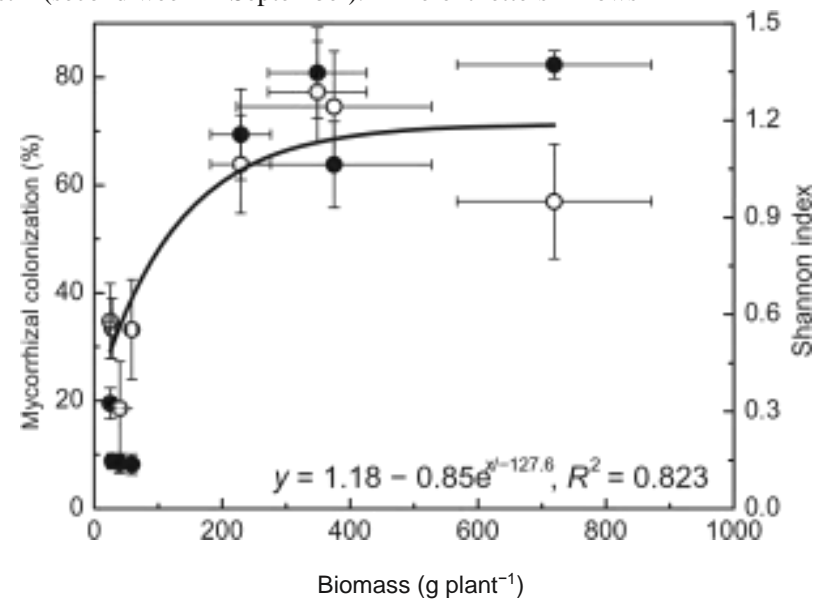

Figure 3. Relationship of diversity (white circles) of fungal taxa or proportion of ectomycorrhizal roots colonization (black circles) with biomass of beech $(n=5,1 \mathrm{SE})$. Diversity was fitted by exponential increase (line).

MacKenzie 2008). Despite these uncertainties, our study clearly demonstrates that ectomycorrhizal colonization of roots was strongly related to beech net primary productivity and that increasing colonization was accompanied with increasing diversity of the fungal community at root tips.

In our study, shade grown beech trees showed acclimation of photosynthetic parameters and productivity similar to those in 
previous studies (Tognetti et al. 1998; Lichtenthaler et al. 2000). The strong dependence of mycorrhizal colonization on host productivity may shed further light on the significance of below-ground hyphal networks connecting trees with each other in forest ecosystems. Our data suggest that strongly light-limited understory plants may not be able to invest sufficient own carbon into mycorrhizas, whose functions may, however, be essential to satisfy their nitrogen requirement in nutrient-limited environments. In fact, oak seedlings connected with congeneric trees by mycorrhizal nets contained increased foliar nitrogen concentrations compared with unconnected seedlings (Dickie, Koide \& Steiner 2002). In understory, the connection of carbonlimited trees with a hyphal web subsidized by lightexposed, mature trees might be ecologically beneficial and grant their survival, even if the actual carbon exchange between the trees is marginal (Robinson \& Fitter 1999).

\section{Functional differences of recent photosynthate and stored carbohydrates for ectomycorrhizas}

The observed relationships between mycorrhizal colonization, species richness, and diversity might have been expected according to ecological concepts relating resistance of invasibility of new species to resource limitations (Levine \& D’Antonio 1999). In such a system higher 


\section{Druebert et al.}

photoassimilate production would increase fine root productivity and, thus, increase the ability of novel EM taxa to invade (Davis, Grime \& Thompson 2000). In the wider context of our data, this explanation is, however, too simplistic. First, we always analysed the same number of vital root tips; the high proportion of non-mycorrhizal root tips in light-limited plants indicates that'available' root tip per se is an insufficient indicator to predict ectomycorrhizal diversity. Second, the carbohydrate concentrations in the root systems of sunacclimated trees were similar to those of light-limited trees. Therefore, root carbohydrate concentrations can also be excluded as the direct cause of increased proportion of root colonization and increased diversity of ectomycorrhizal fungi. It is possible that carbon exudation is required to attract and enable the installation of ectomycorrhiza, and that the interaction is further regulated by hormonal signals (Mathesius 2003; Morgan, Bending \& White 2005). The links between such plant-born signals and diversity of EM fungi will have to be addressed in future studies.

As ectomycorrhizal symbiosis involves reciprocal transfer of carbon and nutrients between plant and fungi, feedbacks of low EM colonization on plant nutrition might have been expected. The foliar $\mathrm{N}$ concentrations in beech of our study were in the range of those found in field studies across Europe (Bauer, Schulze \& Mund 1997; Duquesnay et al. 2000). Increased foliar $\mathrm{N}$ concentrations in shadeacclimated plants reflect higher investment into photosynthetic structures and excluded negative effects of low EM colonization on nutrient supply to these plants. The sunexposed plants with high biomass production contained lower $\mathrm{N}$ concentrations in their tissues, but wholeplant $\mathrm{N}$ uptake was strongly increased because of the significant increase in biomass production. Among the abundant EM taxa colonizing roots of sun-exposed trees, two species, an uncultured EM and Tuber maculatum, were characterized by emanating hyphae which may extend the soil volume used for nutrient foraging (Agerer 2001). Such EM associations may be important to satisfy higher $\mathrm{N}$ demand of sunexposed plants. Furthermore, the maintenance of such species may be too expensive for carbon-limited beech because long distance exploration types of EM fungi, e.g. Suillus sp., have higher carbon demand than species with a short radius of soil exploration or species that may acquire carbon by saprotrophic mechanisms, e.g. Piloderma sp. (Heinosala, Hurme \& Sen 2004; Saravesi et al. 2008). Overall, our results show that mycorrhizal colonization is under host control, and that host carbon productivity is a pre-condition for ectomycorrhizal diversity.

This conclusion was also supported by the results of girdling experiments. Ectomycorrhizal fungi are considered important sinks for carbon, which are rapidly supplied with carbohydrates from current photosynthetic activities (Melin \& Nilsson 1957; Heinosala et al. 2004). In pulsechase feeding experiments with Scots pine, maximal $\mathrm{C}$ uptake in the extramatrical mycelium occurred within $3 \mathrm{~d}$ (Leake et al. 2001). One might, therefore, expect that disruption of this carbon supply would cause a relatively rapid loss in ectomycorrhizas. However, this was neither observed in the present relatively short-term study nor in other girdling experiments with mature beech in forest ecosystems lasting more than 1 year (Pena et al., unpublished results). Similarly, Kuikka et al. (2003) and Högberg et al. (2001), who restricted carbon flux to roots of Scots pine by defoliation or girdling, respectively, found no rapid loss in ectomycorrhizal colonization proportion or loss in diversity. Since beech - unlike conifers - may have the possibility to circumvent the girdle by carbon transport through axial parenchyma cells, we have also demonstrated that girdling was very efficient in disrupting basipetal carbon transfer. Therefore, our data document that the consumption of carbohydrate reserves must have enabled the maintenance and survival of ectomycorrhizal as well as non-mycorrhizal roots. This was supported by the observation that increases in necromass in response to girdling were not significant. The higher fraction of dead root tips in sun- compared with shade-exposed trees may be caused by slower decomposition of ectomycorrhizal than of non-mycorrhizal roots (Langley, Chapman \& Hungate 2006).

In our study, the dominance structures of EM were surprisingly stable since Evenness did not change across all treatments. However, there were small changes in the community composition on roots of girdled trees compared with those of non-girdled trees at the two different sampling dates. At first glance, this was surprising since one might assume that the same host species in same soil might have the same preferences for ectomycorrhizal partners. However,it has also been shown that the carbon demand of fungal taxa is different and that plants allocate more carbon to more beneficial mutualists (Rosling, Landahl \& Finlay 2004;Bever et al. 2009). Therefore, the community pattern is expected to change, if fungi with lower carbon demand would be favoured or would be more competitive when the supply with recent photoassimilates stopped.We noted that the abundance of a common fungal taxon (MT13) of shadeacclimated trees, which forms only small EM structures with a smooth mantle, increased consistently in girdled sunacclimated trees. However, since only one taxon was involved, the overall changes in community structures were small.

Our study suggests that carbon stored in the root systems is normally not used by the fungal partners, but can apparently be shunted to support ectomycorrhizal structures if supply with current assimilates is restricted. How this sink regulation functions is an interesting question, but beyond the scope of this study. The supply with plant-derived carbon from recent photosynthate or storage pools appears to be flexible and the regulation may be important to understand ectomycorrhizal diversity patterns. Since the abundance of most major fungal species did not change after girdling, we assumed that installation of ectomycorrhizal structures may be more energy-consuming than their maintenance. Therefore, it may be more favourable to keep the mycorrhiza than to abandon and re-install them. Investment and running costs should be included in cost-benefit analysis and other modelling exercises to quantify and assess root-mycorrhizal interactions. Economic market models depending on the exchange of 'goods' may be too simplistic (Kummel \& Salant 2006). 


\section{ACKNOWLEDGMENTS}

We are grateful to the German Science Foundation for financial support (grants GRK 1086:The role of biodiversity for biogeochemical cycles and biotic interactions in temperate deciduous forests and FOR788: Competitive mechanisms of water and nitrogen partitioning in beechdominated deciduous forests) and to the country of Lower Saxony for funding the Haeckel-Excellence Cluster. We thank G. Lehmann (Laboratory for Radioisotopes) for excellent technical assistance of the radioactive experiments.

\section{REFERENCES}

Agerer R. (1987-2006) Colour Atlas of Ectomycorrhizae. EinhornVerlag, Schwäbisch Gmünd, Germany.

Agerer R. (2001) Exploration types of ectomycorrhizae:a proposal to classify ectomycorrhizal mycelial systems according to their patterns of differentiation and putative ecological importance. Mycorrhiza 11, 107-114.

Avis P.G., Mueller G.M. \& Lussenhop J. (2008) Ectomycorrhizal fungal communities in two North American oak forests respond to nitrogen addition. New Phytologist 179, 472-483.

Bais H.P., Weir T.L., Perry L.G., Gilroy S. \& Vivanco J.M. (2006) The role of root exudates in rhizosphere interactions with plants and other organisms. Annual Reviews of Plant Biology 57, 233- 266.

Bardgett R.D.,Bowman W.D.,Kaufmann R. \& Schmidt S.K. (2005) A temporal approach to linking aboveground and belowground ecology. Trends in Ecology and Evolution 20, 634-641.

Bauer G., Schulze E.D. \& Mund M. (1997) Nutrient contents and concentrations in relation to growth of Picea abies and Fagus sylvatica along a European transect. Tree Physiology 17, 777- 786.

Beutler H.O. (1978) Enzymatic determination of starch in food by hexokinase method. Starch 30, 309-312.

Bever J.D., Richardson S.C., Lawrence B.M., Holmes J. \& Watson M. (2009) Preferential allocation to beneficial symbiont with spatial structure maintains mycorrhizal mycelium. Ecology Letters 12, 1321.

Brandrud T.E. (1995) The effects of experimental nitrogen addition on the ectomycorrhizal fungus flora in an oligotrophic spruce forest at Gardsjön Sweden. Forest Ecology and Management 71, 111-121.

Buée M., Vairelles D. \& Garbaye J. (2005) Year-round monitoring of diversity and potential metabolic activity of the ectomycorrhizal community in a beech (Fagus silvatica) forest subjected to two thinning regimes. Mycorrhiza 15, 235-245.

Carfrae J.A., Skene K.R., Sheppard L.J., Ingleby K. \& Crossley A. (2006) Effects of nitrogen with and without acidified sulphur on an ectomycorrhizal community in a Sitka spruce (Picea sitchensis Bong. Carr) forest. Environmental Pollution 141, 131-138.

Cheng S., Widden P. \& Messier C. (2005) Light and tree size influence belowground development in yellow birch and sugar maple. Plant and Soil 270, 321-330.

\section{Beech productivity and ectomycorrhiza}

Davis M.A., Grime J.P. \& Thompson K. (2000) Fluctuating resources in plant communities: a general theory of invasibility. Journal of Ecology 88, 528-534.

De Roman M., Claveria V. \& De Miguel A.M. (2005) A revision of the descriptions of ectomycorrhizas published since 1961. Mycological Research 109, 1063-1104.

Dehlin H., Nilsson M.C., Wardle D.A. \& Shevtsova A. (2004) Effects of shading and humus fertility on growth, competition, and ectomycorrhizal colonization of boreal forest tree seedlings. Canadian Journal of Forest Research 34, 2573-2586.

Dickie I.A., Koide R.T. \& Steiner K.C. (2002) Influences of established trees on mycorrhizas, nutrition, and growth of Quercus ruba seedlings. Ecological Monographs 72, 505-521.

Duquesnay A., Dupouey J.L., Clement A., Ulrich E. \& Le Tacon F. (2000) Spatial and temporal variability of foliar mineral concentration in beech (Fagus sylvatica) stands in northeastern France. Tree Physiology 20, 13-22.

Ellenberg H. (1996) Vegetation Mitteleuropas mit den Alpen in ökologischer, dynamischer und historischer Sicht, 5th edn. Ulmer Verlag, Stuttgart, Germany.

Finlay R. \& Söderström B. (1992) Mycorrhiza and carbon flow to the soil.In Mycorrhizal Functioning:An Integrative Plant-Fungal Process (ed. M.F. Allen) pp. 134-160. Chapman and Hall, New York, USA

Gafur A., Schützendübel A., Langenfeld-Heyser R., Fritz E. \& Polle A. (2004) Compatible and incompetent Paxillus involutus isolates for ectomycorrhiza formation in vitro with poplar (Populus $¥$ canescens) differ in $\mathrm{H}_{2} \mathrm{O}_{2}$ production. Plant Biology 6, 91-99.

Gamage H.K., Singhakumara B.M.P. \& Ashton M.S. (2004) Effects of light and fertilization on arbuscular mycorrhizal colonization and growth of tropical rain forest Syzygium tree seedlings. Journal of Tropical Ecology 20, 525-534.

Gehring C.A. (2004) Seed reserves and light intensity affect growth and mycorrhiza development of the seedlings of an Australian rain-forest tree. Journal of Tropical Ecology 20, 345-349.

Godbold D.L. \& Berntson G.M. (1997) Elevated atmospheric $\mathrm{CO}_{2}$ concentration changes ectomycorrhizal morphotype assemblages in Betula papyrifera. Tree Physiology 17, 347-350.

Godbold D.L.,Hoosbeek M.R.,Lukac M.,et al. (2006) Mycorrhizal hyphal turnover as a dominant process for carbon input into soil organic matter. Plant and Soil 281, 15-24.

Grebenc T. \& Kraigher H. (2007) Changes in the community of ectomycorrhizal fungi and increased fine root number under adult beech trees chronically fumigated with double ambient ozone concentration. Plant Biology 9, 279-287.

Grime J.P., Mackey J.M.L., Hillier S.H. \& Read D.J. (1987) Floristic diversity in a model system using experimental microcosms. Nature 328, $420-422$.

van der Heijden M.G.A., Klironomos J.N., Ursic M., Moutoglis P., Streitwolf-Engel R., Boller T., Wiemken A. \& Sanders I.R. (1998) Mycorrhizal fungal diversity determines plant biodiversity, ecosystem variability and productivity. Nature 396, 69-72.

van der Heijden M.G.A., Streitwolf-Engel R., Riedl R., Siegrist S., Neudecker A., Ineichen K., Boller T., Wiemken A. \& Sanders I.R. (2006) The mycorrhizal contribution to plant productivity, plant nutrition and soil structure in experimental grassland. New Phytologist 172, 739-752.

van der Heijden M.G.A., Bardgett R.D. \& van Straalen N.M. (2008) The unseen majority: soil microbes as drivers of plant diversity and productivity in terrestrial ecosystems. Ecology Letters 11, 296-310.

Heinemeyer A., Hartley I.P. \& Evans S.P. (2007) Forest soil $\mathrm{CO}_{2}$ flux: uncovering the contribution and environmental responses of ectomycorrhizas. Global Change Biology 13, 1786-1797.

\section{Druebert et al.}

Heinosala J., Hurme K.R. \& Sen R. (2004) Recent ${ }^{14}$ C-labelled assimilate allocation to Scots pine seedling root and mycorrhizosphere compartments developed on reconstructed podzol humus, E- and Bmineral horizons. Plant and Soil 259, 111-121. Heinrichs H., Brumsack H.J., Loftfield N. \& Konig N. (1986) Improved pressure digestion system for biological and inorganic materials.Zeitschrift für Pflanzen und Bodenkunde 149, 350-353. Hobbie E.A. (2006) Carbon allocation 
to ectomycorrhizal fungi correlates with belowground allocation in culture studies. Ecology 87, 563-569.

Hobbie J.E. \& Hobbie E.A. (2006) N-15 in symbiotic fungi and plants estimates nitrogen and carbon flux rates in Arctic tundra. Ecology 87, 816-822.

Högberg P., Nordgren A., Buchmann N., Taylor A.F.S., Ekblad A., Högberg M.N., Nyberg G., Ottosson-Lofvenius M. \& Read D.J. (2001) Large-scale forest girdling shows that current photosynthesis drives soil respiration. Nature 411, 789-792.

Johnson D., IJdo M., Genney D.R., Anderson I.C. \& Alexander I.J. (2005) How do plants regulate the function, community structure, and diversity of mycorrhizal fungi? Journal of Experimental Botany 56, 1751-1760.

Johnson J.D., Tognetti R., Michelozzi M., Pinzauti S., Minotta G. \& Borghetti M. (1997) Ecophysiological responses of Fagus sylvatica seedlings to changing light conditions. II. The interaction of light environment and soil fertility on seedling physiology. Physiologia Plantarum 101, 124-134.

Jonsson L., Anders D. \& Tor-Erik B. (2000) Spatiotemporal distribution of an ectomycorrhizal community in an oligotrophic Swedish Picea abies forest subjected to experimental nitrogen addition: above- and below-ground views. Forest Ecology and Management 132, 143156.

Kõljalg U., Larsson K.-H., Abarenkov K., et al. (2005) UNITE: a database providing web-based methods for the molecular identification of ectomycorrhizal fungi. New Phytologist 166, 10631068 .

Kranabetter J.M.,Durall D.M. \& MacKenzie W.H. (2008) Diversity and species distribution of ectomycorrhizal fungi along productivity gradients of a southern boreal forest Mycorrhiza. doi: 10.1007/s00572-008-0208-Z

Kuikka K., Härmä E., Markkola A., Rautio P., Roitto M., Saikkonen K., Ahonen-Jonnarth U., Finlay R. \& Tuomi J. (2003) Severe defoliation of Scots pine reduces reproductive investment by ectomycorrhizal symbionts. Ecology 84, 2051-2061.

Kummel M. \& Salant S.W. (2006) The economics of mutualism: optimal utilization of mycorrhizal mutualistic partners by plants. Ecology 87, 892-902.

Landeweert R., Leeflang P., Smit E. \& Kuyper T. (2005) Diversity of an ectomycorrhizal fungal community studied by a root tip and total soil DNA approach. Mycorrhiza 15, 1-6.

Langley J.A., Chapman S.K. \& Hungate B.A. (2006) Ectomycorrhizal colonization slows root decomposition: the post-mortem fungal legacy. Ecology Letters 9, 955-959.

Leake J.R., Donnelly D.P., Saunders E.M., Boddy L. \& Read D.J. (2001) Rates and quantities of carbon flux to ectomycorrhizal mycelium following ${ }^{14} \mathrm{C}$ pulse labeling of Pinus sylvestris seedlings:effects of litter patches and interaction with a wood decomposer fungus. Tree Physiology 21, 71-82.

Levine J.M. \& D'Antonio C.M. (1999) Elton revisited: a review of evidence lining diversity and invasibility. Oikos 87, 15-26.

Lichtenthaler H. \& Wellburn A.R. (1983) Determination of total carotenoids and chlorophyll $\mathrm{a}$ and $\mathrm{b}$ of leaf extracts in different solvents. Biochemical Society Transactions 603, 591-592.

Lichtenthaler H., Babani F., Langsdorf G. \& Buschmann C. (2000) Measurement of differences in red fluorescence and photosynthetic activity between sun and shade leaves by fluorescence imaging. Photosynthetica 38, 521-529.

Lilleskov E.A., Fahey T.J., Horton T.R. \& Lovett G.M. (2002) Belowground ectomycorrhizal fungal community change over a nitrogen deposition gradient in Alaska. Ecology 83, 104-115.

Markkola A.M., Ohtonen R., Tarvainen O. \& Ahonen-Jonnarth U. (1995) Estimates of fungal biomass in Scots pine stands on an urban pollution gradient. New Phytologist 131, 139-147.
Mathesius U. (2003) Conservation and divergence of signalling pathways between roots and soil microbes - the Rhizobiumlegume symbiosis compared to the development of lateral roots, mycorrhizal interactions and nematode-induced galls. Plant and Soil 255, 105119.

Maxwell K. \& Johnson G.N. (2000) Chlorophyll fluorescence - a practical guide. Journal of Experimental Botany 51, 659-668.

Melin E. \& Nilsson H. (1957) Transport of C-14 labelled photosynthate to the fungal associate of pine mycorrhiza.Svensk Botanisk Tidskrift 51, 166-186.

Morgan J.A.W, Bending G.D. \&. White P.J. (2005) Biological costs and benefits to plant-microbe interactions in the rhizosphere. Journal of Experimental Botany 56, 1729-1739.

Parelle J., Roudaut J.-P. \& Ducrey M. (2006) Light acclimation and photosynthetic response of beech (Fagus sylvatica L.) saplings under artificial shading or natural Mediterranean conditions. Annals of Forest Science 63, 257-266.

Parrent J.L., Morris W.F. \& Vigalys R. (2006) $\mathrm{CO}_{2}$-enrichment and nutrient availability alter ectomycorrhizal fungal communities. Ecology 87, 2278-2287.

Pearson J.N., Smith S.E. \& Smith F.A. (1991) Effect of photon irradiance on the development and activity of VA mycorrhizal infection in Allium porrum. Mycological Research 95, 741-746.

Peter M.,Francois A. \& Egli S. (2001) Nitrogen addition in Norway spruce stand altered sporocarp production and below-ground ectomycorrhizal species composition. New Phytologist 149, 311- 325.

Pruett G., Bruhn J.N. \& Mihail J.D. (2008) Colonization of pedunculate oak by the Burgundy truffle fungus is greater with natural than with pelletized lime. Agroforestry Systems 72, 41-50.

Read D.J. \& Perez-Moreno J. (2003) Mycorrhizas and nutrient cycling in ecosystems - a journey towards relevance? New Phytologist 157, 475492.

Robinson D. \& Fitter A. (1999) The magnitude and control of carbon transfer between plants linked by a common mycorrhizal network. Journal of Experimental Botany 50, 9-13.

Rosling A., Landahl B.D. \& Finlay R.D. (2004) Carbon allocation to ectomycorrhizal roots and mycelium colonising different mineral substrates. New Phytologist 162, 795-802.

Rumberger M.D., Münzenberger B., Bens O., Ehrig F., Lentzsch P. \& Hüttl R.F. (2004) Changes in diversity and storage function of ectomycorrhiza and soil organoprofile dynamics after introduction of beech into Scots pine forests. Plant and Soil 264, 111- 126.

Saikkonen K., Ahonen-Jonnarth U., Markkola A.M., Helander M., Tuomi J., Roitto M. \& Ranta H. (1999) Defoliation and mycorrhizal symbiosis: a functional balance between carbon sources and belowground sinks. Ecology Letters 2, 19-26.

Saravesi K., Markkola A., Rautio P., Roitto M. \& Tuomi J. (2008) Defoliation causes parallel temporal responses in a host tree and its fungal symbionts. Oecologia 156, 117-123. Shannon C.E. \& Weaver W. (1949) A Mathematical Theory of Communication. University of Illinois Press, Urbana, IL, USA

Simard S.W., Jones M.D. \& Durall D.M. (2002) Carbon and nutrient fluxes within and between mycorrhizal plants. In Mycorrhizal Ecology. Ecological Studies 157 (eds M.G.A. Van der Heijden \& I.R. Sanders) pp. 33-74. Springer Verlag, Heidelberg, Germany.

Söderström B. (2002) Challenges for mycorrhizal research into the new millennium. Plant and Soil 244, 1-7.

Taylor A.F.S. (2002) Fungal diversity in ectomycorrhizal communities: sampling effort and species detection. Plant and Soil 244, 19-28.

Taylor A.F.S., Martin F. \& Read D.J. (2000) Fungal diversity in ectomycorrhizal communities of Norway spruce (Picea abies (L.) Karst.) and beech (Fagus sylvatica, L.) along north-south transects in Europe. In Carbon and Nitrogen Cycling in European Forest Ecosystems. Ecological Studies (ed. E.D. Schulze) Vol. 142, pp. 343365. Springer Verlag, Berlin, Germany. 
Tognetti R., Minotta G., Pinzauti S., Michelozzi M. \& Borghetti M. (1998) Acclimation to changing light conditions of long-term shadegrown beech (Fagus sylvatica L.) seedlings of different geographic origins. Trees 12, 326-333.

Vierheilig H., Bago B., Lerat S. \& Piche Y. (2002) Shoot-produced, light-dependent factors are partially involved in the expression of the arbuscular mycorrhizal (AM) status of AM host and nonhost plants. Journal of Plant Nutrition and Soil Science 165, 21-25.

Vogelsang K.M., Reynolds H.L. \& Bever J.D. (2006) Mycorrhizal fungal identity and richness determine the diversity and productivity of a tallgrass prairie system. New Phytologist 172, 554-562.

White T.J., Bruns T.D., Lee S.B. \& Taylor J.W. (1990) Amplification and direct sequencing of fungal ribosomal RNA Genes for phylogenetics. In PCR - Protocols and Applications - A Laboratory Manual (eds N. Innis, D. Gelfand, J. Sninsky \& T. White) pp. 315322. Academic Press, New York.

Received 15 December 2008; received in revised form 23 March 2009; accepted for publication 24 March 2009

Beech productivity and ectomycorrhiza

\section{SUPPORTING INFORMATION}

Additional Supporting Information may be found in the online version of this article:

Supplementary file 1A. Morphotypes identified by ITS sequencing. Sequences were compared with two databanks, NCBI and UNITE, respectively.

Supplementary file 1B. The 16 morphotypes found at roots of beech (Fagus sylvatica). Scale bar in $\mathrm{cm}$.

Supplementary file 1C. Relative abundance (\%) of morphotypes and vital non-mycorrhizal root tips of sunexposed and shade-acclimated beech trees (Fagus sylvatica). Root tips were analysed at non-girdled control trees and girdled trees 5 and 10 weeks after girdling. $\mathrm{N}=$ non-mycorrhizal root tips. The total number of vital roots was set as $100 \%$. MT numbers refer to morphotypes in Supplementary file 1B.

Please note: Wiley-Blackwell are not responsible for the content or functionality of any supporting materials supplied by the authors. Any queries (other than missing material) should be directed to the corresponding author for the article. 


\section{THESIS DECLARATIONS}

Declarations of the authors own contributions to manuscripts with multiple authors

Chapter 4 Ectomycorrhiza as a link between trees (Fagus sylvatica) and belowground food web

- Plant care during the experiment, plant sample preparation and chemical analysis (a part of fine roots), EM harvest, molecular identification and chemical analysis.

Appendix 1 Roots from beech (Fagus sylvatica L.) and ash (Fraxinus excelsior L.) differentially affect soil microorganisms and carbon dynamics

- Morphological and biomass analysis, sample preparation and ${ }^{13} \mathrm{C}$ and ${ }^{15} \mathrm{~N}$ analysis in plant samples (a part of fine roots), EM harvest, molecular identification and chemical analysis:

Appendix 2 Beech carbon productivity as driver of ectomycorrhizal abundance and diversity

- Analysis of ${ }^{14} \mathrm{C}$ allocation on girdled and intact beech saplings. Experimental setup, plant labelling, sample preparation and chemical analysis. 


\section{Plagiarism declaration}

To best of my knowledge and belief, this thesis is my own work, all sources have been properly acknowledged, and the assessment task contains no plagiasm.

Kerttu Valtanen 